C. 2

A Selected Bibliography of Research, Management, and Biology of

Alberta's Native Ungulates

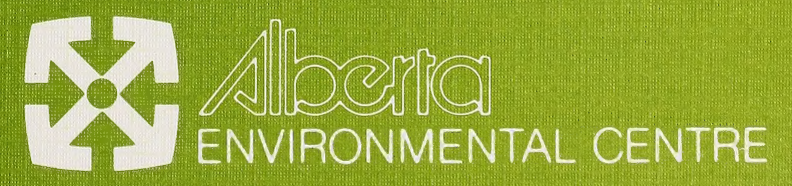


Digitized by the Internet Archive in 2015

https://archive.org/details/selectedbibliogr00stel 


\section{A SELECTED BIBLIOGRAPHY OF}

\section{RESEARCH, MANAGEMENT,}

\section{AND BIOLOGY OF}

\section{ALBERTA'S NATIVE UNGULATES}

(2nd Edition)

by

J.B. Stelfox, L. Peleshok, and M.T. Nietfeld

Wildlife Biology Branch

Animal Sciences Division

Alberta Environmental Centre 
This report may be cited as:

Stelfox, J.B., L. Peleshok, and M.T. Nietfeld. 1991. A Selected Bibliography of Research, Management, and Biology of Alberta's Native Ungulates. Alberta Environmental Centre, Vegreville, AB. AECV92-B1. $110 \mathrm{pp}$.

ISBN 0-7732-0547-0 


\section{TABLE OF CONTENTS}

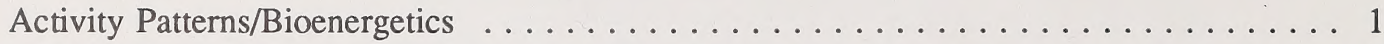

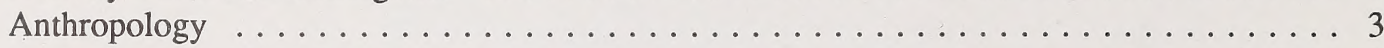

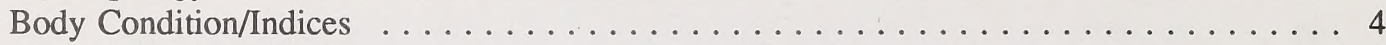

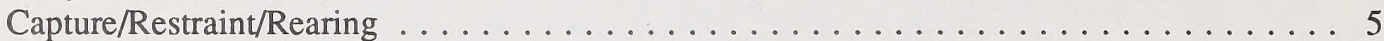

Census Techniques . . . . . . . . . . . . . . . . . . . 7

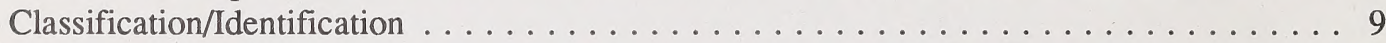

Dentition/Ageing . . . . . . . . . . . . . . . . . . . 10

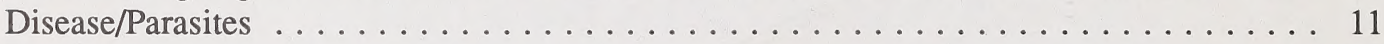

Economics . . . . . . . . . . . . . . . . . 18

Effects of Agriculture . . . . . . . . . . . . . . . . 19

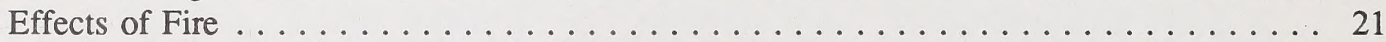

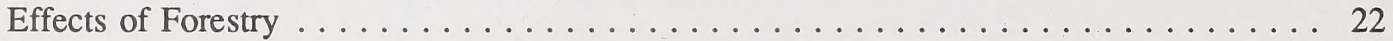

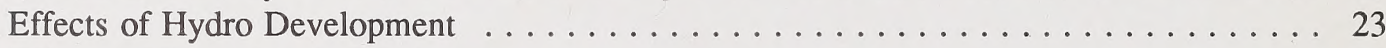

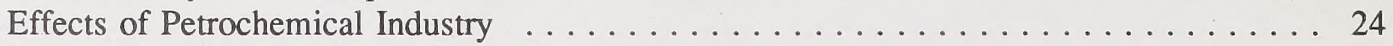

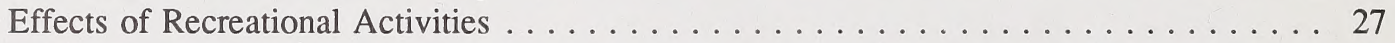

Effects of Settlements . . . . . . . . . . . . . . . . . . . . . 29

Effects of Transportation ........................ 30

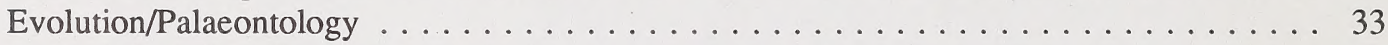

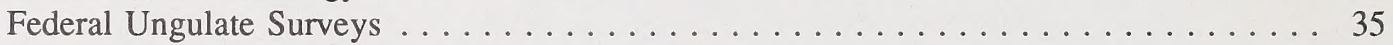

Forage Availability/Use . . . . . . . . . . . . . . . . . . . . . 39

Game Ranching/Farming . . . . . . . . . . . . . . . . . . 44

General Research/Biology . . . . . . . . . . . . . . . . . . . . . . . . 47

General Status/Distribution . . . . . . . . . . . . . . . . . . . . 49

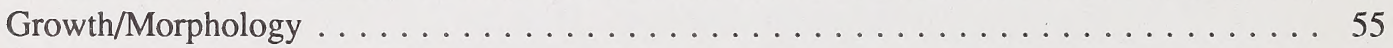

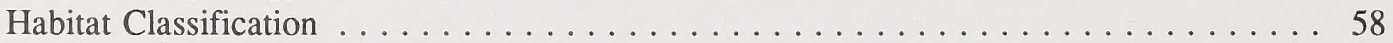

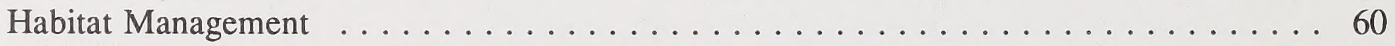

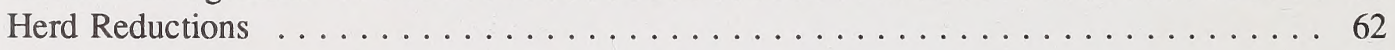

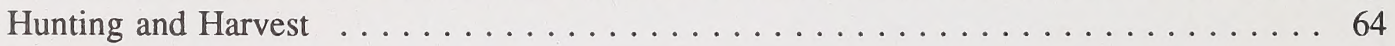

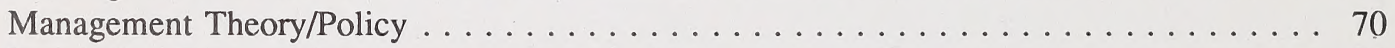

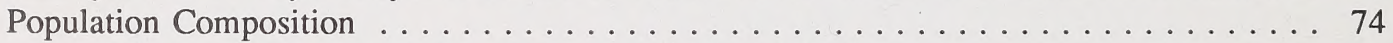

Predation/Natural Mortality . . . . . . . . . . . . . . . . . 76

Provincial Ungulate Surveys . . . . . . . . . . . . . . . . . . . . 79

Provisioning Programs . . . . . . . . . . . . . . . . . . . 100

Reproduction . . . . . . . . . . . . . . . . . . . . . . 101

Resource Availability/Use . . . . . . . . . . . . . . . . . . . . . . . . 103

Social Organization/Behaviour . . . . . . . . . . . . . . . . . . . . . . . . 107

Ungulate Translocations . . . . . . . . . . . . . . . . . . . . 109 


\title{
SUMMARY
}

This bibliography represents an update of $A$ Selected Bibliography of Research and Management of Alberta's Native Ungulates (Stelfox, 1988). It is the intention of the Alberta Environmental Centre to prepare updated versions every two or three years. In addition to this hardcopy bibliography, electronic databases in both MS-DOS (Procite) and MacIntosh (Filemaker Pro) format are available free upon request from the Alberta Environmental Centre. It is the responsibility of the user to purchase their own software copies of Procite and Filemaker Pro. Please send requests for data discs or additional hard copies to:

\author{
Librarian \\ Alberta Environmental Centre \\ Postal Bag 4000 \\ Vegreville, Alberta T9C 1T4
}

The purpose of this bibliography is to assist those who study and/or manage Alberta hoofed mammals. Major target groups include the primary management agencies (Alberta Fish and Wildlife Division, Canadian Wildlife Service, Parks Canada, Alberta Environment, Alberta Forest Service, and Canadian Forest Service), faculty and students of universities, colleges, and technical institutes, academic researchers, consultants, and curatorial staff at museums.

This bibliography is a compendium of provincial literature dating from the 1940's to mid1991, and is comprised of approximately 2400 articles including journal publications, published books, dissertations, unpublished reports, and the proceedings and transactions of conferences.

The nine ungulate species considered in this bibliography are the white-tailed deer (Odocoileus virginianus), mule deer (Odocoileus hemionus), caribou (Rangifer tarandus), wapiti 
"elk" (Cervus elaphus), moose (Alces alces), pronghorn (Antilocapra americana), mountain goat

(Oreamnos americanus), bighorn sheep (Ovis canadensis), and bison (Bison bison).

References are arranged alphabetically within sections that address specific research and management subject areas. Criteria used in selecting articles include:

- those which present the findings of research on or management of indigenous ungulates within the geographical border of Alberta. Studies involving populations that cross Alberta's borders (i.e. Wood Buffalo National Park) have been included.

- those general articles, authored by residents of Alberta that address one or more of native ungulate species found in Alberta

- $\quad$ those studies, though conducted beyond Alberta's borders, used animals recently translocated from Alberta.

Many entries address more than one of the chosen management and research subject areas.

To minimize the length of this document, articles are included only in that subject area which is the major focus of the article. The reader is therefore recommended to peruse related subject areas.

Although some university libraries collect unpublished government reports, the most complete collections are found in government libraries. The major repository for the Fish and Wildlife Division is presently located on the 9th Floor of the Bramalea Building (9915 108 Street, Edmonton, Alberta T5K 2C9). The Canadian Wildlife Service library is in the Atria II Building (4998 - 98 Avenue, Edmonton, Alberta T6B 2X3). Park Canada's regional library is in Room 540, 220 - Fourth Avenue, S.E., Calgary, Alberta (P.O. Box 2989, Station M, Calgary, Alberta T2P 3H8). The repository location of each unpublished government report represents the library where the report is available, not the branch or district office from which the report was written. 
Entries were compiled through searches of government libraries, scientific journals, conference proceedings, and of numerous personal bibliographies kindly provided by Alberta's ungulate researchers and managers. Numerous published bibliographies were also consulted and include: A bibliography of Alberta mammalogy (Ealey, D.M., 1987; Alberta Culture), A buffalo round-up; a selected bibliography (Arthur, G.W., 1985; University of Regina), The American bison (Bison bison); an initial bibliography (Miller, G., 1977; Canadian Wildlife Service and Parks Canada), and Annotated wildlife references for Banff and Jasper National Parks (McDougall, K.A., McGillis, J.R., and Holroyd, G.L., 1985; Canadian Wildlife Service).

We would appreciate receiving complete references of publications and reports pertaining to Alberta's ungulates that are not included in this report and those written following the printing of this bibliography. 



\begin{tabular}{|c|c|c|}
\hline Author(s) / Editor & Date & Title \\
\hline $\begin{array}{l}\text { Best, D.A., Lynch, G.M. and } \\
\text { Rongstad, O.J. }\end{array}$ & 1978 & $\begin{array}{l}\text { Seasonal activity patterns of moose in the Swan Hills, } \\
\text { Alberta. }\end{array}$ \\
\hline $\begin{array}{l}\text { Bobek, B., Kunelius, R. and } \\
\text { Weiner, J. }\end{array}$ & 1983 & $\begin{array}{l}\text { Energy balance and population structure of elk (Cervus } \\
\text { elaphus nelsoni Nelson, 1902) in Banff National Park. }\end{array}$ \\
\hline Chabot, D. & $\begin{array}{l}\text { (in } \\
\text { prep.) }\end{array}$ & $\begin{array}{l}\text { The effect of alertness on the heart rate and metabolic rate } \\
\text { of wapiti (Cervus elaphus). }\end{array}$ \\
\hline Chappel, R.W. & 1978 & $\begin{array}{l}\text { Bioenergetics of Rocky Mountain bighorn sheep Ovis } \\
\text { canadensis canadensis Shaw. }\end{array}$ \\
\hline Chappel, R.W. and Hudson, R.J. & 1978 & Energy costs of feeding in Rocky Mountain bighorn sheep. \\
\hline Chappel, R.W. and Hudson, R.J. & 1978 & Winter bioenergetics of Rocky Mountain bighorn sheep. \\
\hline Chappel, R.W. and Hudson, R.J. & 1979 & Energy cost of standing in Rocky Mountain bighorn sheep. \\
\hline Chappel, R.W. and Hudson, R.J. & 1980 & $\begin{array}{l}\text { Prediction of energy expenditures by Rocky Mountain } \\
\text { bighorn sheep. }\end{array}$ \\
\hline Christopherson, R.J. and Hudson, & 1978 & Effect of temperature and wind on cattle and bison. \\
\hline
\end{tabular}

R.J.

Christopherson, R.J., Hudson,

R.J. and Christopherson, M.K.

Christopherson, R.J., Hudson,

R.J. and Richmond, R.J.

Franzmann, A.W.

1979 Seasonal energy expenditures and thermoregulatory responses of bison and cattle.

1978 Comparative winter bioenergetics of American bison, yak, Scottish highland and hereford calves.

1972 Environmental sources of variation of bighom sheep physiologic values.

1971 Variation in rectal temperature in bighom sheep.

Franzmann, A.W. and Hebert, D.M.

Gates, C.C. and Hudson, R.J.

Gates, C.C. and Hudson, R.J.

Geist, V., Stemp, R.E. and

Johnson, R.H.

Hudson, R.J.

1985

Hudson, R.J. and Christopherson, 1985 R.J.

Hudson, R.J. and White, R.G.

1985

Computer simulation of energy budgets.

Hudson, R.J. and White, R.G. 1985 (eds.).

Hudson, R.J., Watkins, W.G. and 1985 Pauls, R.W.

MacArthur, R.A., Geist, V. and Johnston, R.A.

MacArthur, R.A., Geist, V. and Johnston, R.A.

MacArthur, R.A., Johnston, R.H. 1979 and Geist, V.

Morgantini, L.E. and Hudson, R.J. 1988

Pauls, R.W., Hudson, R.J. and Sylven, S.

Renecker, L.A.

Effects of posture and activity on metabolic responses of wapiti to cold.

Heart rate telemetry on bighom sheep (Ovis canadensis) as a means to investigate disturbance.

Body size, energetics and adaptive radiation.

Maintenance metabolism.

Bioenergetics of wild herbivores.

Seasonal bioenergetics of wapiti in western Canada.

Physiological correlates of social behaviour in bighom sheep : a field study using electrocardiogram telemetry.

Cardiac responses of bighom sheep to trapping and radio instrumentation.

Factors influencing heart rate in free-ranging bighom sheep : a physiological approach to the study of wildlife harassment.

Migratory patterns of wapiti (Cervus elaphus) in Banff National Park.

Energy expenditure of free-ranging wapiti.

Bioenergetics and behavior of moose (Alces alces) in the
Journal / Conference / Etc.

Proceedings of North American Moose Conference Workshop, 14, 109-125.

Acta Theriologica, 28, 259-272.

Ph.D. Thesis: University of Calgary, Calgary.

M.Sc. Thesis. University of Alberta, Edmonton.

Acta Theriologica, 23, 359-363.

Canadian Journal of Zoology, 56, 2388-2393.

Journal of Wildlife Management, 43, 261-263.

Canadian Journal of Zoology, 58, 1908-1912.

Department of Animal Science, University of Alberta Feeders' Day Report, 57, 40-41.

Canadian Joumal of Animal Science, 59 , 611-617.

Acta Theriologica, 23, 49-54.

Journal of Wildlife Management, 36, 924-932.

Joumal of Wildlife Management, 35, 488-494.

Acta Theriologica, 23, 49-54.

Joumal of Wildlife Management, 43, 564-567. aspen-dominated boreal forest. pp. 92-99. In: The ecological impact of outdoor recreation on mountain areas in Europe and North America.

pp. 1-24. In: Bioenergetics of wild herbivores. Hudson, R.J. and White, R.G. (eds.). CRC Press, Boca Raton, FL

pp. 121-142. In: Bioenergetics of wild herbivores. Hudson, R.J. and White, R.G. (eds.). CRC Press, Boca Raton, FL. herbivores. Hudson, R.J. and White, R.G. (eds.). CRC Press, Boca Raton, FL.

CRC Press, Boca Raton, FL.

Royal Society of New Zealand Bulletin, 22, $447-452$.

Journal of Zoology, 196, 401-415.

Canadian Journal of Zoology, 64, 1197-1200.

Canadian Journal of Zoology, 57, 2010-2021.

Canadian Field Naturalist, 102, 12-19.

60th Annual Feeders' Day Report., Department of Animal Science, University of Alberta, Edmonton.

Ph.D. Thesis. University of Alberta, Edmonton. pp. 261-290. In: Bioenergetics of wild 
Author(s) / Editor

Renecker, L.A. and Hudson, R.J. 1983

Renecker, L.A. and Hudson, R.J. 1985

Renecker, L.A. and Hudson, R.J. 1986

Renecker, L.A. and Hudson, R.J. 1989

Renecker, L.A. and Hudson, R.J. 1990

Renecker, L.A., and Hudson, R.J. 1991

Renecker, L.A., Hudson, R.J. and 1982 Freddy, D.J.

Renecker, L.A., Hudson, R.J., Christopherson, M.K. and Arelis, C.

Stemp, R.

1983

Struthsaker, T.T. and Parsekian, A. 1965

Title

Winter activity budgets of free-ranging moose, using a calibrated heart rate index.

Telemetered heart rate as an index of energy expenditure in moose (Alces alces).

Seasonal energy expenditures and thermoregulatory responses of moose.

Seasonal activity budgets of moose in aspen-dominated boreal forests, central Alberta.

Behavioral and thermoregulatory responses of moose to high ambient temperatures and insect harassment in aspen-dominated forests.

Thermoregulatory and behavioral responses of moose: Is large body size an adaptation or constraint?

Heart rate as an index of energy expenditure in moose, using two telemetry systems.

1978 Effect of posture, feeding, low temperature and wind on energy expenditures of moose calves.

Heart rate responses of bighorn sheep to environmental factors and harassment with management implications.

The relation of age, sex and time of day to activity in free-ranging elk (Cervus canadensis).
Journal / Conference / Etc.

In: Proceedings of the 4th International Conference on Wildlife Biotelemetry. Halifax, NS.

Comparative Biochemical Physiology, 82, $161-165$

Canadian Journal of Zoology, 64, 322-327.

Journal of Wildlife Management, 53, 296-302.

Alces, 26, 66-72.

In: Proceedings of 3rd International Moose Symposium, Syktyvkar, USSR. (in press)

International Symposium on Biotelemetry, 7, $116-119$

Proceedings of North American Moose Conference Workshop, 14, 126-140.

M.Sc. Thesis. University of Calgary, Calgary.

Canadian Wildlife Service, Edmonton. Unpublished report. 
Anthropology

\begin{tabular}{|c|c|c|c|}
\hline Author(s) / Editor & Date & Title & Journal / Conference / Etc. \\
\hline Arthur, G.W. & 1974 & $\begin{array}{l}\text { An introduction to the ecology of early historic communal } \\
\text { bison hunting among the northem Plains Indians. }\end{array}$ & Ph.D. Thesis. University of Calgary, Calgary. \\
\hline Brumley, J.H. & 1976 & $\begin{array}{l}\text { Ramillies: A late prehistoric bison kill and campsite located } \\
\text { in southeastern Alberta, Canada. }\end{array}$ & $\begin{array}{l}\text { Archaeological Survey of Canada Paper No. 55, } \\
\text { National Museum of Man, National Museums of } \\
\text { Canada, Ottawa, ON. }\end{array}$ \\
\hline Brumley, J.H. & 1978 & $\begin{array}{l}\text { McKean complex subsistence and hunting strategies in the } \\
\text { southern Alberta plains. }\end{array}$ & Plains Anthropologist, 23, 175-193. \\
\hline Frison, G.C. & 1980 & Man and bison relationships in North America. & Canadian Journal of Anthropology, 1, 75-76. \\
\hline Gruhn, R. & 1969 & $\begin{array}{l}\text { Preliminary report on the Muhlbach site: a Besant bison } \\
\text { trap in central Alberta. }\end{array}$ & $\begin{array}{l}\text { National Museums of Canada Bulletin, 232, } \\
128-156 .\end{array}$ \\
\hline Novakowski, N.S. & 1989 & Historical origin of national park plains bison. & $\begin{array}{l}\text { Department of the Environment, Canadian Park } \\
\text { Service, Natural Resources Branch, Ottawa. }\end{array}$ \\
\hline Polk, M.R. & 1979 & $\begin{array}{l}\text { Bison jump sites in the northwestern plains of North } \\
\text { America: a locational analysis. }\end{array}$ & $\begin{array}{l}\text { M.A. Thesis. Michigan State University, East } \\
\text { Lansing, MI. }\end{array}$ \\
\hline Reeves, B.O. & 1978 & Bison killing in the southwestern Alberta Rockies. & Plains Anthropologist, 23, 63-78. \\
\hline Reeves, B.O. & 1978 & $\begin{array}{l}\text { Head-smashed-in: } 5500 \text { years of bison jumping in the } \\
\text { Alberta plains. }\end{array}$ & Plains Anthropologist, 23, 151-174. \\
\hline Rollans, $\mathbf{M}$. & 1987 & $\begin{array}{l}\text { Interpreting the function of bison drive lanes at } \\
\text { Head-Smashed-In Buffalo Jump, Alberta. }\end{array}$ & M.A. Thesis. University of Alberta, Edmonton. \\
\hline
\end{tabular}




Author(s) / Editor Date Title Journal / Conference / Etc.

Bandy, P.J., Cowan, I. McT.,

Kitts, W.D. and Wood, A.J.

Barrett, M.W.

1956

A method for the assessment of the nutritional status of wild ungulates.

1975 A serologic survey of pronghorns in Alberta and Saskatchewan.

Barrett, M.W. and Chalmers, G.A. 1976

Barrett, M.W. and Chalmers, G.A. 1976

Hawley, A.W.L.

1984

Hawley, A.W.L.

1985

Hawley, A.W.L.

1987

Hawley, A.W.L. and Peden, D.G. 1982

Hebert, D., Hebert, J. and Caskey, 1984 M.

Kingsley, M.C.S.

Kistner, T.P., Trainer, C.E. and Hartmann, N.A.

LeResche, R.E., Seal, U.S.,

Karns, P.D. and Franzmann, A.W.

McGillis, J.R.

Olson, W.C.

Renecker, L.A.

(in prep.)

Baseline hematologic and clinical chemistry values for pronghorns.

Hematologic values for adult free-ranging pronghorn.

Moose condition indicies of moose slaughtered at Elk Island 1980-1982.

Seasonal condition indicies of moose in Elk Island National Park.

Identifying bison ration groups by multivariate analysis of blood composition.

Effect of ration, season and animal handling on composition of bison and cattle blood.

Fecal nitrogen as a determinant of animal condition in bighorn sheep.

Analysis of bison marrow fat data, Wood Buffalo National Park.

1980 A field technique for evaluating physical condition of deer.

A review of blood chemistry of moose and other Cervidae with emphasis on nutritional assessment.

The kidney fat index as an indicator of condition in various age and sex classes of moose.

Fecal crude protein monitoring as a means of monitoring elk body condition.

1991 Seasonal nutritional cycles of ungulates in Elk Island National Park, Alberta.

Shackleton, D.M.

1973 Population quality and bighom sheep (Ovis canadensis canadensis).

Treichel, B. and Hall, B.

1975 Necropsy deer progress report 1974-1975.

1976 Necropsy deer progress report 1975-1976.

Treichel, B. and Hall, B.

Treichel, B. and Hall, B.

1977 Necropsy deer progress report 1976-1977.

Wishart, W.D. and Brochu, D.

1982
An evaluation of horn and skull characteristics as a measure of population quality in Alberta bighoms.
Canadian Journal of Zoology, 34, 48-52.

Alberta Fish and Wildlife Division, Edmonton. Unpublished report.

pp. 104-118. In: Proc. 7th Biennial Pronghorn Antelope Workshop. Twin Falls, ID. Feb. 24-26, 1976.

Canadian Journal of Zoology, 55, 448-455.

Alberta Environment Center, Vegreville. Unpublished report.

2nd International Workshop on Wildlife Nutrition and Bioenergetics. Fort Collins, AZ, January, 1975.

Journal of Wildlife Management, 51, 893-900.

Journal of Wildlife Disease, 18, 321-338.

pp. 310-316. Proceedings of 4th Biennial Symposium on Northern Wild Sheep and Goat Council. Hoef, M., ed.). Whitehorse, YK.

Canadian Wildlife Service, Edmonton. Unpublished report.

Wildlife Society Bulletin 8, 11 .

Naturaliste Canadien, 101, 263-290.

Proceedings of North American Moose Conference and Workshop, 8, $105-114$.

Elk Island National Park, Parks Canada, Calgary. Unpublished report.

Report to Elk Island National Park. Unpublished report.

$\mathrm{Ph}$.D. Thesis. University of Calgary, Calgary.

Alberta Fish and Wildlife Division, Edmonton. Unpublished report.

Alberta Fish and Wildlife Division, Edmonton. Unpublished report.

Alberta Fish and Wildlife Division, Edmonton. Unpublished report.

Biennial Symp. Northern Wild Sheep and Goat Council, $3,127-142$. 


\begin{tabular}{|c|c|c|}
\hline Author(s) / Editor & Date & Title \\
\hline Barrett, M.W. & 1973 & $\begin{array}{l}\text { Investigations related to pronghom antelope kid tagging in } \\
\text { Alberta. }\end{array}$ \\
\hline Barrett, M.W. & 1973 & Unpublished records of elk immobilization with M99. \\
\hline Barrett, M.W. & 1974 & $\begin{array}{l}\text { A capture and marking technique for pronghorn antelope } \\
\text { (Antilocapra americana Ord) kids in Alberta. }\end{array}$ \\
\hline Barrett, M.W. & 1978 & $\begin{array}{l}\text { A technique for capturing pronghorn (Antilocapra } \\
\text { americana) fawns in Alberta. }\end{array}$ \\
\hline $\begin{array}{l}\text { Barrett, M.W., Nolan, J.W. and } \\
\text { Roy, L.E. }\end{array}$ & 1982 & $\begin{array}{l}\text { Evaluation of hand-held net-guns to capture large } \\
\text { mammals. }\end{array}$ \\
\hline Bertwistle, J. & 1989 & Plains and Wood bison handling report. \\
\hline Bradford, W. & 1985 & $\begin{array}{l}\text { Bighom sheep marking program, Jasper National Park } \\
\text { progress report } 1985 .\end{array}$ \\
\hline Brown, W.K. & 1988 & $\begin{array}{l}\text { Fall classification and capture program, Greater Jasper } \\
\text { Ecosystem Caribou Research program. }\end{array}$ \\
\hline $\begin{array}{l}\text { Cowan, I. McT., Wood, A.J. and } \\
\text { Nordan, H.C. }\end{array}$ & 1962 & $\begin{array}{l}\text { Studies in tranquilization and immobilization of deer } \\
\text { (Odocoileus). }\end{array}$ \\
\hline Ericksen, G.L. & 1973 & $\begin{array}{l}\text { Marking and capturing technique used at Ram Mountain } \\
\text { sheep project. }\end{array}$ \\
\hline Ewaschuk, E. & 1966 & Collar tagging device for bighorn sheep. \\
\hline
\end{tabular}

Festa-Bianchet, M. and Jorgenson, 1985 J.T.

Flook, D.R., Robertson, J.R., Hermanrude, O.R. and Buechner,

H.K.

Fuller, T.K. and Keith, L.B.

Haigh, J.C.

Haigh, J.C.

Haigh, J.C.

Hebert, D.M. and McFetridge, R.J. 1978

Hudson, R.J. and Tennessen, T. 1978

Hudson, R.J., Tennessen, T. and Sturko, A.

Jorgenson, J.T., Samson, J., and 1990 Festa-Bianchet.

Kemper, J.B.

LeResche, R.E. and Lynch, G.M.

Lynch, G.

Lynch, G.M.

Lynch, G.M.

Lynch, G.M. and Hanson, J.A. $1979^{\circ}$ Hyaluronidase as an adjunct in an immobilizing mixture for moose.

Use of xylazine and ketamine to immobilize bighom sheep in Alberta.

Succinylcholine chloride for immobilization of North American elk

Immobilization of woodland caribou with etorphine.

Capture of moose with fentanyl and xylazine.

Capture of woodland caribou in Canada.

Chemical immobilization of North American game mammals.

Observations on the behaviour and injuries incurred by bison during capture and handling.

1976 Behavioural and physiological reactions of bison to handling during an anthrax vaccination program in Wood Buffalo National Park.

Immobilization of bighom sheep with xylazine

Elk Island portable elk trap.

A trap for free-ranging moose.

Immobilization of moose with M99.

Live trapping moose at mineral licks in Alberta.

Projectile mechanisms for chemical restraint of wildlife.

1981 Use of etorphine to immobilize moose. hydrochloride and reversal with idazoxan.
Journal / Conference / Etc.

Paper presented at 1973 Prairie Habitat Conference, Brooks. Alberta Fish and Wildlife Division, Edmonton. Unpublished report.

Alberta Fish and Wildlife Division, Edmonton. Unpublished report.

Alberta Fish and Wildlife Division, Edmonton. Unpublished report.

Alberta Fish and Wildlife Division, Edmonton. Unpublished report.

Wildlife Society Bulletin, 10, 108-114.

Elk Island National Park. Unpublished report.

Parks Canada, Calgary. Unpublished report.

Parks Canada, Calgary. Unpublished report.

Canadian Joumal of Comparative Medical Veterinary Science, 26, 57-61.

Alberta Fish and Wildlife Division, Edmonton. Unpublished report.

Alberta Fish and Wildlife Division, Edmonton. Unpublished report.

Joumal of Wildlife Management, 49, 162-165.

Joumal of Wildlife Management, 26, 334-336.

Joumal of Wildlife Management, 45, 745-748.

Journal of Zoo Animal Medicine, 8, 22-29.

pp. 110-115. In: Proceedings of American Association of Zoological Veterinarians.

Journal of American Veterinary Medical Association, 175, 916-917.

Alberta Fish and Wildlife Division, Edmonton. Unpublished report.

Animal Regulation Studies, 1, 345-353.

In: Wood Buffalo National Park bison research 1972-76 1976 annual report. Stelfox, J.G. (compiler). Canadian Wildlife Service, Edmonton.

Journal of Wildlife Diseases, 26, 522-527.

Alberta Fish and Wildlife Division, Edmonton. Unpublished report.

Journal of Wildlife Management, 37, 87-89.

Alberta Fish and Wildlife Division, Edmonton. Unpublished report.

Proceedings of North American Moose Conference and Workshop, 14, 56-67.

pp. 97-99. In: Proceeding of 1987 Alberta Game Grower's Association Conference. Red Deer, Oct. 23-24, 1987.

Journal of Wildlife Management, 45, 981-985. 


\begin{tabular}{ccc}
\hline Author(s) / Editor & Date & Title \\
\hline Olsen, C.D. and Renecker, L.A. & 1985 & Xylazine immobilization of wapiti: antagonism with
\end{tabular}
yohimbine and 4-aminopyridine.

Renecker, L.A. and Olsen, C.D. 1986

Renecker, L.A., Bertwistle, J., Miller, M., Kozak, H.M., Hudson, R.J., Chabot, D. and Maclean, S.

Robertson, J.R., Hermanrude, O.R. and Flook, D.R.

Sadler, T.E.

Stelfox, J.G., and Robertson, J.R. 1976

Stelfox, J.G., Hudson, R.J. and Onderka, F.W.

Wasem, C.R.

Welch, D.A., Drew, M.L. and Samuel, W.D.

Wishart, W.D.

Wishart, W.D., Smith, K.,

Jorgenson, J. and Lynch, G.

Young, B.F.
1991 R51163 as a sedative for handling and transporting wapiti, plains bison, and mountain goats.

1960 Report on elk tagging program. Banff, Kootenay and Yoho National Parks, June 7 to November 30, 1960.

1966 Big game tagging in wildlife management units F308 and S402.

Immobilizing bighorn sheep with succinylchloine chloride and phencyclidine hydrochloride.

1977 Techniques for marking, tagging and radio-collaring bison.

1967 Immobilization of Rocky Mountain elk in Waterton Lakes National Park.

1985 Techniques for rearing moose calves with resulting weight gains and survival.

1968 Tagging bighorns.

1980 The evolution of capturing bighorns in Alberta.

1972 Rochester deer trapping program 1972 progress report.
Journal / Conference / Etc.

pp. 176. In: Proceedings of 1984 Western States and Provinces Elk Workshop. Nelson, R.W. (ed.) Edmonton. April 17-19, 1984.

New Zealand Deer Farmer, 28, 31.

Journal of Wildlife Disease (in review)

Parks Canada, Calgary. Unpublished report.

Alberta Fish and Wildlife Division, Edmonton. Unpublished report.

Journal of Wildlife Management, 40, 174-176.

Section G: pp. 1-5. In: Wood Buffalo National Park bison research. Stelfox, J.G. (compiler). Prepared for Parks Canada, Calgary; prepared by Canadian Wildlife Service, Edmonton.

Wildlife Management, Glacier National Park, MT. Unpublished report.

Alces, 21, 475-491.

Alberta Lands, Forests, Parks, Wildlife, 11, 20.

pp. 590-600. In: Proceedings of Biennial Symposium of Northern Wild Sheep and Goat Council. Hickey, W.O. (ed.). Salmon, ID.

Alberta Fish and Wildlife Division, Edmonton. Unpublished report. 


\begin{tabular}{lcl}
\hline \multicolumn{1}{c}{ Author(s) / Editor } & Date & \multicolumn{1}{c}{ Title } \\
\hline Beier, P. & 1988 & $\begin{array}{l}\text { Motion-sensitive radio collars for estimating white-tailed } \\
\text { deer activity. }\end{array}$ \\
$\begin{array}{l}\text { Boyd, M., Hall, W., Langford, G. } \\
\text { and Cook, A. }\end{array}$ & 1982 & $\begin{array}{l}\text { Integration of landsat imagery into a program for aerial } \\
\text { surveying of deer populations in Alberta. }\end{array}$ \\
Bradford, W. & 1987 & $\begin{array}{l}\text { Evaluation of the Jasper National Park bighom sheep } \\
\text { marking program. }\end{array}$ \\
Cook, A. & 1980 & $\begin{array}{l}\text { Stratified random deer census design and trial for WMU } \\
\text { P208, P210 and P220 using the double observer } \\
\text { (front-back) quadrat procedure. Jan. 14-22, 1980. }\end{array}$ \\
\hline
\end{tabular}

Cook, A.R. and Hall, B.

Cook, R.D. and Jacobson, J.O. (helicopters vs. fixed wing).

A visibility bias model for aerial surveys of moose on the AOSERP study area.

Gudmundson, L.

1985 Revised survey format for antelope management areas in the southern region (1984-1985).

Gunson, J.R.

1975

Gunson, J.R.

1979 Use of night-lighted census in management of deer in

Hansen, $\mathbf{R}$.

Hilton, M. and Wishart, W.

Hudson, R.J.

Intera Environmental Consultants

Ltd.

Jacobson, J. and Cook. R.D.

Kunelius, R.

Lungle, K.J.

Lynch, G.M.

1969

Lynch, G.M.

Miller, F.L. and Gunn, A. (eds.)

Nellis, C. and Keith, L.B.

Olson, W.

Stelfox, J.G.

Stelfox, J.G.

Stelfox, J.G. Alberta and Saskatchewan.

1985

Observations of deer and other wildlife during night lighting, 1971-74. Creek watershed of Jasper National Park.

976 Comparison of fecal $\mathrm{pH}$ of white-tailed deer vs. mule deer.

982 Bighorn sheep.

976 Report on thermal scanning of ungulates in Elk Island National Park 1976.

Application of visibility bias models to aerial deer censuses, Red Deer, Alberta 1977-78.

\section{National Park.}

The applicability of the square mile quadrat census method for moose in the Wapiti area, 1970.

Experimental big game drive near Robb, Alberta.

Best timing of moose surveys in Alberta.

Symposium on census and inventory methods for populations and habitats. Banff, April 10, 1980. winter.

An Assessment of the forward looking infrared (FLIR) system, for ungulate aerial surveys and searches for lost persons.

Wildlife and wildlife habitat census inventory.

An evaluation of winter aerial survey methods for determining bison populations and distributions in Wood Buffalo National Park, 18-20 February 1975.

1975
Techniques for the study of mountain caribou in the Blue
Journal / Conference / Etc.

Journal of Wildlife Management, 52, 11-13, 1988.

pp. 222-227. In: Proceedings of 7th Canadian Symposium on remote sensing. Winnipeg, MB, Sept. 8-11, 1981.

Parks Canada, Calgary. Unpublished report.

Alberta Fish and Wildlife Division, Edmonton. $66 \mathrm{pp}$. Unpublished report.

Alberta Fish and Wildlife Division, Edmonton. Unpublished report.

Prepared for the Alberta Oil Sands Environmental Research Program; prepared by Interdisciplinary Systems Ltd.

Alberta Fish and Wildlife Division, Edmonton. Unpublished report.

Alberta Fish and Wildlife Division, Edmonton. Unpublished report.

Wildlife Society Bulletin, 7, 259-267.

Parks Canada, Calgary. Unpublished report.

Alberta Fish and Wildlife Division, Edmonton Unpublished report.

In: CRC handbook of census methods for terrestrial vertebrates. David, D.E. (ed.). CRC Press, Boca Raton, Fl.

Prepared for Parks Canada, Calgary. Unpublished report

Alberta Fish and Wildlife Division, Edmonton. Unpublished report.

Banff National Park, Canada Parks Service.

Alberta Fish and Wildlife Division, Edmonton. Unpublished report.

Alberta Fish and Wildlife Division, Edmonton. Unpublished report.

Proceedings of North American Moose Conference and Workshop, 11, 141-153.

Canadian Wildlife Service, Edmonton. Unpublished report.

Department of Wildlife Ecology, University of Wisconsin, WI. Unpublished report.

Elk Island National Park. Unpublished report.

Canadian Wildlife Service, Edmonton. Unpublished report.

Parks Canada, Calgary; Canadian Wildlife Service, Edmonton. Unpublished report.

Canadian Wildlife Service, Edmonton. Unpublished report. 


\begin{tabular}{|c|c|c|c|}
\hline Author(s) / Editor & Date & Title & Journal / Conference / Etc. \\
\hline Stelfox, J.G. and Kingsley, M.C.S & 1976 & Statistical reliability of total bison counts. & $\begin{array}{l}\text { Section E: pp. 36-46. In: Wood Buffalo National } \\
\text { Park bison research: } 1972-76 \text {. Stelfox, J. G. } \\
\text { (compiler). Prepared for Parks Canada; Calgary; } \\
\text { prepared by Canadian Wildlife Service, } \\
\text { Edmonton. Unpublished report. }\end{array}$ \\
\hline Stelfox, J.G. and McGillis, J.R. & 1977 & $\begin{array}{l}\text { Ungulate surveys manual for prairie and western Canadian } \\
\text { National Parks. }\end{array}$ & $\begin{array}{l}\text { Canadian Wildlife Service, Edmonton. } \\
\text { Unpublished report. }\end{array}$ \\
\hline Stelfox, J.G. and Tempany, I. & 1975 & $\begin{array}{l}\text { Aerial oblique photography at } 600,1200,1800 \text { and } 2400 \\
\text { feet, Wood Buffalo National Park, August } 27,1975 \text {. }\end{array}$ & $\begin{array}{l}\text { Canadian Wildlife Service, Edmonton. } \\
\text { Unpublished report. }\end{array}$ \\
\hline Stelfox, J.G. and Tempany, I. & 1975 & $\begin{array}{l}\text { Aerial oblique photography for age: sex structure } \\
\text { identification of bison in Wood Buffalo National Park. } \\
\text { June } 10-13,1975 \text {. }\end{array}$ & $\begin{array}{l}\text { Canadian Wildlife Service, Edmonton. } \\
\text { Unpublished report. }\end{array}$ \\
\hline Stelfox, J.G. and Tempany, I. & 1976 & $\begin{array}{l}\text { Aerial oblique photography for determining calf and } \\
\text { yearling components of bison herds in Wood Buffalo } \\
\text { National Park, August } 27,1975 \text {. }\end{array}$ & $\begin{array}{l}\text { Canadian Wildlife Service, Edmonton. } \\
\text { Unpublished report. }\end{array}$ \\
\hline Stelfox, J.G. and Venables, J.G. & 1974 & $\begin{array}{l}\text { Past, current and potential wildlife census techniques in } \\
\text { western and prairie Canadian National Parks. }\end{array}$ & $\begin{array}{l}\text { Canadian Wildlife Service, Edmonton. } \\
\text { Unpublished report. }\end{array}$ \\
\hline Tempany, I.R. and Cooper, S. & 1975 & $\begin{array}{l}\text { Bison census and survey technique, Wood Buffalo } \\
\text { National Park. }\end{array}$ & $\begin{array}{l}\text { Parks Canada, Calgary; Canadian Wildlife } \\
\text { Service, Edmonton. Unpublished report. }\end{array}$ \\
\hline $\begin{array}{l}\text { Tempany, I.R., Cooper, S. and } \\
\text { Stelfox, J.G. }\end{array}$ & 1976 & Census and survey techniques. & $\begin{array}{l}\text { In: Wood Buffalo National Park bison research } \\
1972-761976 \text { annual report. Stelfox, J.G. } \\
\text { (compiler). Canadian Wildlife Service, } \\
\text { Edmonton. }\end{array}$ \\
\hline $\begin{array}{l}\text { Tempany, I.R., Stelfox, J.G. and } \\
\text { Lyster, G.G. }\end{array}$ & 1976 & Reactions of bison to aircraft herding and surveys. & $\begin{array}{l}\text { In: Wood Buffalo National Park bison research } \\
1972-761976 \text { Annual Report. Stelfox, J.G. } \\
\text { (compiler). Canadian Wildlife Service, } \\
\text { Edmonton. }\end{array}$ \\
\hline
\end{tabular}




\begin{tabular}{|c|c|c|c|}
\hline Author(s) / Editor & Date & Title & Journal / Conference / Etc. \\
\hline Banfield, A.W.F. & 1961 & A revision of the reindeer and caribou genus Rangifer. & $\begin{array}{l}\text { National Museum of Canada Bulletin, 177, } \\
\text { (Biological Series Number 66). }\end{array}$ \\
\hline Banfield, A.W.F. & 1961 & The wood bison type specimen. & Journal of Mammalogy, 42, 553-554. \\
\hline Bhambhani, R.N. & 1968 & $\begin{array}{l}\text { Karyotypic and cytotaxonomic study of domestic cattle and } \\
\text { American bison. }\end{array}$ & M.Sc. Thesis. University of Alberta, Edmonton. \\
\hline Clarke, J.L. & 1978 & The great arc of the wild sheep. & University of Oklahoma Press, Norman, OK. \\
\hline Geist, V. & 1989 & $\begin{array}{l}\text { "Taxonomy: on an objective definition of subspecies, taxa } \\
\text { as legal entities, and its application to Rangifer tarandus } \\
\text { Lin. 1758." }\end{array}$ & $\begin{array}{l}\text { Proceedings of the 4th North American Caribou } \\
\text { Workshop, St. John's, Newfoundland, Nov. 1, } \\
1989 .\end{array}$ \\
\hline Geist, V. & 1991 & $\begin{array}{l}\text { On the taxonomy of giant sheep (Ovis ammon Linnaeus, } \\
\text { 1766). }\end{array}$ & Canadian Journal of Zoology, 69, 706-723. \\
\hline Karsten, P. & 1975 & $\begin{array}{l}\text { Don't be buffaloed --- by a bison; a history of Alberta } \\
\text { herds. }\end{array}$ & $\begin{array}{l}\text { Dinny's Digest Calgary Zoological Society, } 2 \text {, } \\
\text { 3-13. }\end{array}$ \\
\hline $\begin{array}{l}\text { McClymont, R.A., Thompson, } \\
\text { J.R. and Fenton, M. }\end{array}$ & 1977 & $\begin{array}{l}\text { Developments in meat identification at the University of } \\
\text { Alberta. }\end{array}$ & $\begin{array}{l}\text { pp.183-211. In: Proceedings of the Forensic } \\
\text { Science Symposium. Calgary, April 13-15, } \\
1977 .\end{array}$ \\
\hline Neuman, P.W. & 1971 & $\begin{array}{l}\text { An examination of genetic variation in plains bison (Bison } \\
\text { bison bison), wood bison (B. b. athabascae) and their } \\
\text { hybrids. }\end{array}$ & $\begin{array}{l}\text { Canadian Wildlife Service, Edmonton. } \\
\text { Unpublished report. }\end{array}$ \\
\hline Neuman, P.W. & 1971 & $\begin{array}{l}\text { Electrophoresis in the study of genetic variation between } \\
\text { plains bison (Bison bison bison) and wood bison (Bison } \\
\text { bison athabascae). }\end{array}$ & $\begin{array}{l}\text { Canadian Wildlife Service, Edmonton. } \\
\text { Unpublished report. }\end{array}$ \\
\hline Peden, D.G. and Kraay, G.J. & 1979 & $\begin{array}{l}\text { Comparison of blood characteristics in plains bison, wood } \\
\text { bison and their hybrids. }\end{array}$ & Canadian Journal of Zoology, 57, 1778-1784. \\
\hline Schultz, F. & 1967 & Identification of bison skulls. & Blue Jay, 25, 191-192. \\
\hline Smith, H.C. & 1985 & A checklist of the mammals of Alberta. & $\begin{array}{l}\text { Provincial Museum Alberta, Natural History } \\
\text { Occasional Paper No. 6. Edmonton. }\end{array}$ \\
\hline Tyrrell, J.B. & 1916 & $\begin{array}{l}\text { David Thompson's narrative of his explorations in western } \\
\text { America 1748-1812. }\end{array}$ & The Champlain Society, Toronto, ON. \\
\hline van Zyll de Jong, C.G. & 1979 & $\begin{array}{l}\text { Progress report on the morphometric analysis of extant } \\
\text { forms of bison with emphasis on the systematic status of } \\
\text { surviving wood bison. }\end{array}$ & $\begin{array}{l}\text { National Museum of Canada. Ottawa, ON. } \\
\text { Unpublished report. }\end{array}$ \\
\hline van Zyll de Jong, C.G. & 1986 & Taxonomic status of the wood bison. & $\begin{array}{l}\text { Paper submitted to the wood bison advisory } \\
\text { group, January } 1986 \text {. National Museum of } \\
\text { Natural Sciences, Ottawa, ON. }\end{array}$ \\
\hline Ying, K.L. and Peden, D.G. & 1977 & Chromosomal homology of wood bison and plains bison. & Canadian Journal of Zoology, 55, 1759-1762. \\
\hline
\end{tabular}


Dentition/Ageing

\begin{tabular}{|c|c|c|c|}
\hline Author(s) / Editor & Date & Title & Journal / Conference / Etc. \\
\hline Armstrong, G.G. & 1965 & $\begin{array}{l}\text { An examination of the cementum of the teeth of Bovidae } \\
\text { with special reference to its use in age determination. }\end{array}$ & M.Sc. Thesis. University of Alberta, Edmonton. \\
\hline Armstrong, G.G. & 1967 & Aging bison by tooth succession. & $\begin{array}{l}\text { Alberta Fish and Wildlife Division, Edmonton. } \\
\text { Unpublished report. }\end{array}$ \\
\hline Fuller, W.A. & 1954 & The first premolar and the canine tooth in bison. & Journal of Mammalogy, 35, 454-456. \\
\hline Fuller, W.A. & 1959 & The homs and teeth as indicators of age in bison. & Journal of Wildlife Management, 23, 342-344. \\
\hline Geist, V. & 1966 & Validity of horn segment counts in aging bighorn sheep. & Journal of Wildlife Management, 30, 634-635. \\
\hline Haynes, G. & 1984 & Tooth wear in northern bison. & Journal of Mammalogy, $65,487-491$. \\
\hline Kerwin, M.L. and Mitchell, G.J. & 1971 & $\begin{array}{l}\text { The validity of the wear-age technique for Alberta } \\
\text { pronghorns. }\end{array}$ & Journal of Wildlife Management, 35, 743-747. \\
\hline Mundy, K.R.D. & 1962 & Age determination in the bison (Bison bison). & $\begin{array}{l}\text { Department of Zoology, University of Alberta, } \\
\text { Edmonton. Unpublished report. }\end{array}$ \\
\hline Novakowski, N.S. & 1964 & $\begin{array}{l}\text { The use of eye-lens weight, tooth replacement, cementum } \\
\text { deposition and dressed weight as aging criteria in the } \\
\text { bison. }\end{array}$ & $\begin{array}{l}\text { Canadian Wildlife Service, Edmonton. } \\
\text { Unpublished report. }\end{array}$ \\
\hline Novakowski, N.S. & 1965 & $\begin{array}{l}\text { Cemental deposition as an age criterion in bison, and the } \\
\text { relation of incisor wear, eye-lens weight, and dressed } \\
\text { bison carcass weight to age. }\end{array}$ & Canadian Journal of Zoology, 43, 173-178. \\
\hline Steele, D.G. and Parama, W.D. & 1979 & $\begin{array}{l}\text { Supernumerary teeth in moose and variations in tooth } \\
\text { number in North American Cervidae. }\end{array}$ & Journal of Mammalogy, $60,852-854$. \\
\hline Thomas, D.C. & 1977 & $\begin{array}{l}\text { Metachromatic staining of dental cementum for mammalian } \\
\text { age determination. }\end{array}$ & Journal of Wildlife Management, 41, 207-210. \\
\hline
\end{tabular}




\begin{tabular}{|c|c|c|}
\hline Author(s) / Editor & Date & Title \\
\hline $\begin{array}{l}\text { Anderson, R.C. and Lankester, } \\
\text { M.W. }\end{array}$ & 1974 & $\begin{array}{l}\text { Infectious and parasitic diseases and arthropod pests of } \\
\text { moose in North America. }\end{array}$ \\
\hline $\begin{array}{l}\text { Anderson, R.C., Lankester, M.W. } \\
\text { and Strelive, U.R. }\end{array}$ & 1966 & $\begin{array}{l}\text { Further experimental studies of Pneumostrongylus tenuis } \\
\text { in cervids. }\end{array}$ \\
\hline Anonymous. & 1987 & $\begin{array}{l}\text { Status report on Wood Bison (Bison bison athabascae) in } \\
\text { Canada, } 1987 .\end{array}$ \\
\hline Anonymous. & 1989 & $\begin{array}{l}\text { Agriculture Canada submission to the Northern Diseased } \\
\text { Bison Environmental Assessment Panel. }\end{array}$ \\
\hline Anonymous. & 1989 & $\begin{array}{l}\text { Compendium of government submissions and technical } \\
\text { specialists reports in response to the panel information } \\
\text { requirements document. }\end{array}$ \\
\hline Anonymous. & 1989 & Dealing with the diseases of bison in Northem Canada. \\
\hline Anonymous. & 1989 & $\begin{array}{l}\text { Evaluation of brucellosis and tuberculosis in bison in } \\
\text { Northem Canada. }\end{array}$ \\
\hline Anonymous. & 1990 & Compendium of supplementary submissions. \\
\hline Anonymous. & 1990 & $\begin{array}{l}\text { Northern Diseased Bison, Report of the Environmental } \\
\text { Assessment Panel. }\end{array}$ \\
\hline Anonymous. & 1990 & $\begin{array}{l}\text { Transcripts of the Community and Technical Hearings of } \\
\text { the Northern Diseased Bison Environmental Assessment } \\
\text { Panel. Jan. } 16-26,1990 \text {. }\end{array}$ \\
\hline
\end{tabular}

Banfield, A.W.F,

1956

An investigation of ticks as disease vectors in Banff National Park, Alberta.

Barrett, M.W. and Chalmers, G.A. 1972

Capillaria Hepatica (Nematoda: Trichuridae) in pronghorn antelope (Antilocapra americana Ord) in Alberta.

Barrett, M.W. and Chalmers, G.A. 1973 Congenital anomalies in a neonatal white-tailed deer in Alberta.

Barrett, M.W. and Chalmers, G.A. 1977

Blood, D.A.

Boag, D.A. and Wishart, W.D. 1982

Broughton, E. and Currier, A.A. 1971

Brown, J.H. and Kohis, G.M. 1950

Chalmers, G.A. and Barrett, M.W. 1974

Chalmers, G.A. and Barrett, M.W. 1974

Chalmers, G.A. and Barrett, M.W. 1977

Chalmers, G.A. and Barrett, M.W. 1977

Chalmers, G.A. and Barrett, M.W. 1982

Chalmers, G.A., Vance, H.N. and 1964 Mitchell, G.J.

Choquette, L.P.E.

Choquette, L.P.E.

Choquette, L.P.E. and Broughton, 1967 E.

Choquette, L.P.E. and Broughton, 1967 E.
Physiological and disease investigations of bison.

Contagious ecthyma in Rocky Mountain bighorn sheep.

Distribution and abundance of a terrestrial gastropod on a winter range of bighorn sheep in southwestern Alberta.

Vaccination of bison and their surveillance in Wood Buffalo National Park, and anthrax outbreak and its control in bison at Hook Lake in the Northwest Territories.

The ticks of Alberta with special reference to distribution.

Dermatomycosis in mule deer in Alberta.

Infectious pododermatitis in a pronghorn antelope in Alberta.

Capture myopathy in pronghoms in Alberta, Canada.

Trauma induced paralysis in a moose calf.

Capture myopathy.

An outbreak of epizootic hemorrhagic disease in wild ungulates in Alberta.

Report on studies on bison in Canada 1960-61.

Anthrax in bison. Control program. Report covering the period May 15, 1965 to October 31, 1965.

Anthrax in bison: Wood Buffalo National Park and the Northwest Territories report for the year 1967.

Report on the program for the control of anthrax in bison at Wood Buffalo National Park on the health status of bison slaughtered in the park during the fiscal year 1965-66.
Journal / Conference / Etc.

Naturaliste Canadien, 10, 23-50.

Canadian Journal of Zoology, 44, 851-861.

Wood Bison Recovery Team. COSEWIC. Ottawa, 87 pp.

Agriculture Canada. 96 pp.

Northern Diseased Bison Environmental Assessment Panel. FEARO, Ottawa, 295 pp.

Government of Canada. Newsletter No. 1. $8 \mathrm{pp}$. Bison Disease Task Force. 229 pp.

Northern Diseased Bison Environmental Assessment Panel. FEARO, Ottawa, 308 pp.

Federal Environmental Review Assessment Office. $47 \mathrm{pp}$

Vol. 1-9, FEARO, Ottawa, 1874 pp.

Canadian Journal of Zoology, 34, 417-423.

Journal of Wildlife Disease, 8, 332-334.

Alberta Fish and Wildlife Division, Edmonton. Unpublished report.

In: Bison research 1977 annual report. Canadian Wildlife Service, Edmonton.

Journal of Wildlife Management, 35, 270-275.

Canadian Joumal of Zoology, 60, 2633-2640.

Canadian Wildlife Service, Ottawa, ON. Unpublished report.

Canadian Journal of Research, 28, 197-205.

Journal of Wildlife Disease, 10, 74-76.

Journal of Wildlife Disease, 10, 60-62.

Journal of American Veterinarian Medical Association, 171, 918-923.

Canadian Field Naturalist, 91, 94-95.

pp. 84-94. In Non-infectious diseases of wildlife. Hoff, G.L. and Davis, J.W. (eds.). Iowa State University Press, Ames, IA.

Wildlife Disease, 42, 1-6.

Canadian Wildlife Service, Ottawa, ON.

Canadian Wildlife Service, Ottawa, ON. Unpublished report.

Canadian Wildlife Service, Ottawa, ON. Unpublished report.

Canadian Wildlife Service, Ottawa, ON. Unpublished report. 


\begin{tabular}{lrl}
\hline \multicolumn{1}{c}{ Author(s) / Editor } & Date & \multicolumn{1}{c}{ Title } \\
\hline $\begin{array}{l}\text { Choquette, L.P.E. and Stewart, } \\
\text { R.C. }\end{array}$ & 1959 & $\begin{array}{l}\text { Report on studies on bison in Canada - 1959. 1 - Data on } \\
\text { the slaughter, reproduction and health of bison at Wood } \\
\text { Buffalo National Park. }\end{array}$ \\
$\begin{array}{l}\text { Choquette, L.P.E., Broughton, E., } 1972 \\
\begin{array}{l}\text { Currier,A.A., Cousineau, J.G. and } \\
\text { Novakowski, N.S. }\end{array}\end{array}$ & $\begin{array}{l}\text { Parasites and disease of bison in Canada. III. Anthrax } \\
\text { outbreaks in the last decade in northern Canada and control } \\
\text { measures. }\end{array}$ \\
$\begin{array}{l}\text { Choquette, L.P.E., Gallivan, J.F., } 1961 \\
\text { Parasites and diseases of bison in Canada. }\end{array}$
\end{tabular}

Byme, J.L. and Pilipavicius, J.

Choquette, L.P.E., Whitten, L.K., 1957

Rankin, G. and Seal, C.M.

Colwell, D.D.

Colwell, D.D. and Mahrt, J.L.

1981 Ultrastructure of the cyst and merozoites of Sarcocystis from moose (Alces alces) in Alberta, Canada.

Comer, A.H. and Connell, R.

Cousineau, J.G. and McClenaghan, 1965 R.J.

Cowan, I. McT.

Cowan, I. McT.

1948 The occurrence of the granular tape-worm Echinococcus granulosus in wild game in North America.

Cowan, I. McT.

1951 The diseases and parasites of big game mammals of western Canada.

Drew, M.L.

Drew, M.L. and Samuel, W.M.

Reproduction and transmission of the winter tick Dermacentor albipictus (Packard) in central Alberta.

Brucellosis in bison, elk and moose in Elk Island National Park, Alberta.

Anthrax in bison in the Northwest Territories. Parasites, diseases and injuries of game animals in Banff,

Factors affecting transmission of larval winter ticks, Dermacentor albipictus (Packard), to moose, Alces alces L., in Alberta, Canada.

Drew, M.L. and Samuel, W.M. 1986 Reproduction of the winter tick, Dermacentor albipictus, under field conditions in Alberta, Canada.

Festa-Bianchet, M.

1983 Report on a bighom sheep - lungworm study at Sheep River, Alberta 1982.

Festa-Bianchet, $\mathbf{M}$.

1988 A pneumonia epizootic in bighorn sheep, with comments on preventive management.

Festa-Bianchet, M.

1988 Pneumonia epizootic in bighom sheep, with comments on preventative management.

Festa-Bianchet, $M$.

1991 Numbers of lungworm larvae in feces of bighorn sheep: yearly changes, influences of host sex, and effects on host survival.

Festa-Bianchet, M. and Samson, J. 1984 Lamb survival in relation to matemal lungworm load in Rocky Mountain bighorn sheep.

Flook, D.R. and Stenton, J.E.

Fuller, W.A.

Gates, C.C.

Gates, C.C. and Samuel, W.M.

Glines, M.V.

1982 the National Parks of the Canadian Rockies.

Interim report on the incidence of tuberculosis in bison in Wood Buffalo Park. Aspects of the environment - lungworm (Nematoda: Metastrongyloidea) - bighorn sheep (Ovis canadensis canadensis) system.

Prenatal infection of the Rocky Mountain bighom sheep of Alberta with the lungworm Protostrongylus spp.

Final report to Parks Canada on the life history and
Journal / Conference / Etc.

Canadian Wildlife Service, Ottawa, ON. Unpublished report.

Canadian Field-Naturalist, 86, 127-132.

Canadian Veterinarian Journal, 2, 168-174.

Canadian Journal of Comparative Medicine, 21, 199-203.

M.Sc. Thesis. University of Alberta, Edmonton.

Zeitschrift fur Parasitenkunde, 665, 317-329.

Canadian Journal of Comparative Medicine, 22, 9-20.

Canadian Veterinarian Joumal., 6, 22-24.

Lands, Parks, and Forest Branch, National Parks Bureau. Unpublished report.

Journal of Wildlife Management, 12, 105-106.

Proceedings of the Annual Game Conference, 5, 37-64.

M.Sc. Thesis. University of Alberta, Edmonton.

Journal of Wildlife Disease, 21, 274-282.

Canadian Joumal of Zoology, 64, 714-721.

Alberta Fish and Wildlife Division, Edmonton. Unpublished report.

Proceedings of the Northern Wild Sheep and Goat Council, 6, 66-76.

Biennial Symposium Northern Wild Sheep and Goat Council, 6, 66-76.

Canadian Joumal of Zoology, 69, 547-554.

pp. 364-371. In: Proceedings of 4th Biennial Symposium of Northern Wild Sheep and Goat Council. Hoef, M. (ed.). Whitehorse, YK.

Canadian Journal of Zoology, 47, 795-803.

Incidence and abundance of certain parasites in wapiti in

Canadian Wildlife Service, Ft. Smith, NWT. Unpublished report.

M.Sc. Thesis. University of Alberta, Edmonton. population dynamics of the winter tick (Dermacentor albipictus) on moose (Alces alces) in Elk Island National Park.
Journal of Wildlife Disease, 13, 248-250.

Parks Canada, Calgary. Unpublished report. 


\begin{tabular}{ccc}
\hline Author(s) / Editor & Date & Title \\
\hline Glines, M.V. and Samuel, W.M. & 1984 & $\begin{array}{l}\text { The development of the winter tick, Dermacentor } \\
\text { albipictus, and its effect on the hair coat of moose, Alce } \\
\text { alces, of central Alberta, Canada. }\end{array}$
\end{tabular}

Gray, J.B. and Samuel, W.M.

1986

Paralaphostrongylus odocoilei (Nematoda:

Protostrongylidae) and a protostrongylid nematode in woodland caribou (Rangifer tarandus caribou) of Alberta, Canada.

Green, H.U.

1949

Hand, $\mathbf{R}$

1957

Hebert, D.M. and Cowan, I. McT. 1971

Heron, R.D.

1966

1973

Hodgins, D.

Hodgins, D.

Holmes, J.C. and Samuel, W.M.

1974

Holmes, J.C., Mahrt, J.L. and Samuel, W.M.

1987

Hrudka, F., Cawthorn, R.J. and

Haigh, J.C.

Hudson, R.J.

Hudson, R.J.

Hudson, R.J.

Hudson, R.J.

Kennedy, M.J.

1986

Occurrence of Echinococcus granulosus in elk (Cervus canadensis nelsoni), Banff National Park.

White muscle disease in the mountain goat.

Artificial salt lick - Miette hot springs bath house and Rocky Mountain sheep.

Summary report on bison vaccination program - June 1973.

Winter 1973, bison vaccination program - W.B.N.P.

Surveillance study of the parasites of bighorn sheep in the mountain national parks.

Publications of the parasitology group.

1983 The occurrence of coccidia (Eimeriidae) in epididymal semen of a wapiti (Cervus canadensis nelsoni).

1970 Immunology of lungworm (Protostrongylus) infections of the Rocky Mountain bighorn sheep.

1972 Stress-induced immunologic impairment in Rocky Mountain bighorn sheep.

1973

Stress and in vitro lymphocyte stimulation by Phylohemaglutin in Rocky Mountain bighorn sheep.

1975 Lymphoid cell adherence in Protostrongylus (Nematoda: Metastrongyloidea) infections of Rocky Mountain bighorn sheep.

Synopsis of the parasites of vertebrates of Canada helminths and protozoa of terrestrial mammals.

Kennedy, M.J.

1988

Kennedy, M.J. and Newman, R.A. 1986

Kerr, G.R. and Holmes, J.C.

1966

Khan, B.A.

1988

Kingscote, B.F., Yates, W.D.G. and Tiffin, G.B.

Lewis, R.J., Chalmers, G.A., Barrett, M.W. and Bhatnager, R.

Lynch, G.M.

Mahrt, J.L. and Colwell, D.D.

McClymont, R.A.

1987

1977

Diseases of wapiti utilizing cattle range in southwestern Alberta.

Synopsis of the parasites of vertebrates of Canada; ectoparasites of terrestrial mammals.

Parasites of mountain goats in west central Alberta.

Problems with heavy fly infestations: possible solutions.

McCorquodale, S.M. and

DiGiacomo, R.F.

Mitchell, G.J. epidemiology of bovine brucellosis: a review.

1959 The helminth parasites of big game and some carnivores in
Elk disease and pregnancy observations, 1957.

Journal / Conference / Etc.

pp. 1208-1214. In: Acarology VI. Griffith, D.A. and Bowman, C.E. (eds.). Ellis Horwood Ltd., Chichester, UK.

Journal of Wildlife Disease, 22, 48-50.

Canadian Field Naturalist, 63, 204-205.

Banff National Park, Parks Canada, Calgary. Unpublished report.

Joumal of Wildlife Management, 35, 752-756.

Jasper National Park, Parks Canada, Calgary. Unpublished report.

Parks Canada, Calgary. Unpublished report.

Parks Canada, Calgary. Unpublished report.

Department of Zoology, University of Alberta Edmonton. Unpublished report.

Department of Zoology, University of Alberta, Edmonton. Unpublished report.

Canadian Journal of Zoology, 61, 1693-1699.

Ph.D. Thesis. University of British Columbia, Vancouver, BC.

pp. 31-34. In: Proceedings of Northem Wild Sheep Council.

Canadian Joumal of Zoology, 51, 479-482.

Canadian Journal of Zoology, 53, 391-394

Alberta Agriculture, Animal Health Division, Edmonton.

The Queens Printer. Alberta Agriculture, Edmonton.

Alberta Agriculture, Animal Health Division, Edmonton.

Journal of Wildlife Management, 30, 786-790.

pp. 79-82. In: Proceedings of 3rd Annual Alberta Game Growers' Association Conference.

Renecker, L.A. (ed.). Red Deer, Oct. 23-24, 1987.

Journal of Wildlife Disease, 23, 86-91.

Journal of American Veterinary Medical Association, 171, 927-932.

Alberta Fish and Wildlife Division, Edmonton Unpublished report.

Journal of Wildlife Disease, 16, 571-576.

Department of Zoology, University of Alberta, Edmonton. Unpublished report.

Journal of Wildlife Disease, 21, 351-357. Alberta.
Alberta Fish and Wildlife Division, Edmonton. Unpublished report. 


\begin{tabular}{lcl}
\hline \multicolumn{1}{c}{ Author(s) / Editor } & Date & \multicolumn{1}{c}{ Title } \\
\hline Novakowski, N.S. & 1964 & $\begin{array}{l}\text { Report and recommendations concerning the occurrence } \\
\text { and control of anthrax in bison in Wood Buffalo Park and } \\
\text { vicinity. }\end{array}$ \\
Novakowski, N.S. & 1964 & $\begin{array}{l}\text { The effect of disease syndromes on the ecology of the } \\
\text { bison in Wood Buffalo National Park. }\end{array}$ \\
Novakowski, N.S. & 1965 & The effect of disease upon bison, Mackenzie district.
\end{tabular}

Novakowski, N.S.

1978 Parasites and diseases of bison in Canada. IV. Serological survey for brucellosis in bison in Canada.

Novakowski, N.S., Consineau,

J.G., Kolenosky, G.B., Wilton,

G.S. and Choquette, L.P.E.

Onderka, D.K. and Wishart, W.D.

1963 Parasites and diseases of bison in Canada. II. Anthrax epizootic in the Northwest Territories.

1984 A major bighorn die-off from pneumonia in southern Alberta; 1982-1983.

Onderka, D.K., and Wishart, W.D. 1988

Onderka, D.K., Rawluk, S.A., and 1988 Wishart, W.D.

Paulsen, A.C.

Platt, T.R.

Platt, T.R. and Samuel, W.M.

Pledger, D.J.

Pledger, D.J., Samuel, W.M. and

Craig, D.A.

Pybus. M.

1986

Pybus, M.

Pybus, M.

Pybus, M.

Pybus, M.J.

Pybus, M.J.

1991

Pybus, M.J. and Samuel, W.M. 1980

Pybus, M.J. and Samuel, W.M. 1984

Renecker, L.A.
Experimental contact transmission of Pasteurella haemolytica from clinically normal domestic sheep causing Pneumonia in Rocky Mountain Bighom sheep.

Susceptibility of Rocky Mountain Bighorn sheep and domestic sheep to pneumonia introduced by bighorn and domestic livestock strains of Pasteurella haemolytica.

The geographic distribution of muscleworm (Paralaphostrongylus odocoilei) in ungulate populations of Red Deer region III 1977-1978.

The life cycle and systematics of Parelaphostrongylus odocoilei (Nematoda: Metastrongyloidea), a parasite of mule deer (Odocoileus hemionus hemionus), with special reference to the molluscan intermediate host.

Parelaphostrongylus odocoilei life cycle in experimentally infected cervids including the mule deer, Odocoileus $h$. hemionus.

Black flies (Diptera, Simuliidae) of the Swan Hills, Alberta, as possible vectors of Onchocerca cervipedis Wehr and Dikmans, 1935 (Nematoda, Onchocercidae) in moose (Alces alces Linnaeus).

Blackflies (Diptera: Simuliidae) as possible vectors of legworm (Onchocerca cervipedis) in moose of central Alberta.

Liver flukes and lungworms in Cervus elaphus from Rocky Mountain national parks.

A worm, a snail and a fluke could determine how much game you see this fall.

Fasciloides magna in wapiti (Cervus elaphus) in Rocky Mountain national parks in Canada

The world within - the giant liver fluke.

Parelaphostrongylus andersoni Prestwood 1972 and P. Odocoilei (Hobmaier and Hobmaier 1934) (Nematoda: Metastrongyloidea) in two cervid definitive hosts.

Experimental studies of Meningeal worm,

Parelaphostrongylus Tenuis (Nematode), in six species of ungulates.

Pathology of the muscleworm, Parelaphostrongylus odocoilei (Nematoda: Metastrongyloidea), in moose.

Lesions caused by Parelaphostrongylus odocoilei (Nematoda: Metastrongyloidea) in two cervid hosts.

Control of ectoparasites on moose. Wildlife Productivity Annual Report.
Journal / Conference / Etc.

Canadian Wildlife Service, Ft. Smith, NWT. Unpublished report.

Canadian Wildlife Service, Ft. Smith, NWT. Unpublished report.

Canadian Wildlife Service, Ft. Smith, NWT. Unpublished report.

Journal of Wildlife Disease, 14, 329.

Transactions of North American Wildlife Conference, 28, 233-239.

pp. 356-363. In Proceedings of 4th Biennial Symposium on Northern Wild Sheep and Goat Council. Hoefs, M. (ed.). Whitehorse, YK.

Journal of Wildlife Diseases, 24, 663-667, 1988.

Canadian Journal of Veterinary Research, 52, 439-444, 1988.

Alberta Fish and Wildlife Division, Edmonton Unpublished report.

$\mathrm{Ph}$. D. Thesis. University of Alberta, Edmonton.

Experimental Parasitology, 46, 330-338.

M.Sc. Thesis. University of Alberta, Edmonton.

Proceedings of North American Moose Conference and Workshop, 16, 171-202.

Alberta Fish and Wildlife Division, Edmonton. Unpublished report.

In: Western Sportsman, October 1988. pp. 56-59.

Parks Canada, Calgary. Unpublished report.

Western Sportsman, 20 (5). Regina.

Ph.D. Thesis. University of Alberta, Edmonton.

Abstract from Alberta Chapter of the Wildlife Society, 2nd Annual meeting. March 23 and 24, 1991, Edmonton.

Proceedings of North American Moose Conference and Workshop, 16, 152-170.

Veterinary Pathology, 21, 425-431.

Wildlife Productivity Annual Report. Department of Animal Science, University of Alberta, Edmonton. 


\begin{tabular}{lcl}
\hline \multicolumn{1}{c}{ Author(s) / Editor } & Date & \multicolumn{1}{c}{ Title } \\
\hline Robb, L. & 1987 & $\begin{array}{l}\text { Gastropod intermediate hosts of lungworms (Nematoda: } \\
\text { Protostrongylidae) on a Bighorn sheep winter range: } \\
\text { Aspects of transmission. }\end{array}$ \\
Samson, J. & 1984 & $\begin{array}{l}\text { Aspects of the life cycle of Protostrongylus spp. } \\
\text { lungworms of bighorn sheep (Ovis canadensis). }\end{array}$ \\
Samson, J. and Holmes, J.C. & 1985 & $\begin{array}{l}\text { The effect of temperature on rates of development of larval } \\
\text { Protostrongylus spp. (Nematoda: Metastrongyloidea) from } \\
\text { bighom sheep, Ovis canadensis canadensis, in the snail } \\
\text { Vallonia pulchella. }\end{array}$
\end{tabular}

Samson, J., Holmes, J.C.,

1987 Experimental infections of free-ranging Rocky Mountain Jorgenson, J.T. and Wishart, W.D.

Samuel, W., Lynch, G. and induced by the winter tick (Dermacentor al bipictus).

Samuel, W.M.

1968 Endoparasites of domestic ruminants and white-tailed deer.

Samuel, W.M.

1972 Encounters between hunters and parasites of moose in Alberta.

Samuel, W.M.

1972 Taenia krabbei in the musculature of moose: a review.

Samuel, W.M.

1973 Some parasites of moose in Alberta.

Samuel, W.M.

1978 Parasite research in National Parks of westem Canada. I. Ticks on moose, II. Muscleworm of mule deer.

Samuel, W.M.

1978 Summary report to the Alberta Fish and Wildlife Division and Elk Island National Park relating to aerial observations of moose, April, 1978.

Samuel, W.M.

1982 Parasitic infection in woódland caribou of west central Alberta.

Samuel, W.M.

1988 Internal parasites of Alberta's wild ruminants.

Samuel, W.M.

1988 Moving the zoo or the potential introduction of a dangerous parasite into Alberta with its translocated host.

Samuel, W.M.

1991 A partially annotated bibliography of meningeal worm, Parelaphostrongylus tenuis (Nematoda), and its close relatives.

Samuel, W.M. and Barker, M.J. 1979 The winter tick, Dermacentor albipictus (Packard, 1869) on moose, Alces alces (L.) of central Alberta.

Samuel, W.M. and Holmes, J.C. 1974 Search for elaphostrongyline lungworms in cervids from Alberta.

Samuel, W. M. and Trainer, D. D. 1969

Samuel, W.M., Barrett, M.W. and 1976

Lynch, G.M.

Samuel, W.M., Chalmers, G.A., Stelfox, J.G., Loewen, A. and Thomsen, J.J.

Samuel, W.M., Grinnell, E.R. and Kennedy, A.J.

Samuel, W.M., Hall, W.K.,

Stelfox, J.G. and Wishart, W.D.

A technique for survey of some helminth and protozoan infections of white-tailed deer.

Helminths in moose of Alberta.

1975 Contagious ecthyma in bighom sheep and mountain goats in western Canada.

Ectoparasites (mallophaga, anoplura, acari) on mule deer (Odocoileus hemionus) and white-tailed deer (Odocoileus virginianus) of Alberta.

1978 Parasites of mountain goat, Oreamnos americanus (Blainville), of west central Alberta with a comparison of
1980 Hair loss patterns on moose of Alberta presumably

Journal / Conference / Etc.

M.Sc. Thesis. University of Alberta, Edmonton.

M.Sc. Thesis. University of Alberta, Edmonton.

Canadian Journal of Zoology, 63, 1445-1448.

Journal of Wildlife Disease, 23, 396-403.

Proceedings of North American Moose Conference Workshop. Prince Albert, SK.

Transaction of North American Wildlife Conference, 33, 364-372.

Occasional Paper No. 2, Alberta Fish and Wildlife Division, Edmonton. Unpublished report.

Proceedings of North American Moose Conference and Workshop, 8, 18-41.

Department of Extension, University of Alberta, Edmonton.

Prepared for Parks Canada, prepared by the Department of Zoology, University of Alberta, Edmonton. Unpublished report.

Department of Zoology, University of Alberta, Edmonton. Unpublished report.

Contract Report for Alberta Energy and Natural Resources, Fish and Wildlife Division,

Edmonton. Unpublished report.

pp. 71-78. In Proceedings of 3rd Annual Alberta Game Growers' Association Conference. Renecker, L.A. (ed.). Red Deer, Oct. 23-24, 1987.

pp. 85-92. In: Proceedings of 3rd Annual Alberta Game Growers' Association Conference. Renecker, L.A. (ed.). Red Deer, Oct. 23-24, 1987.

Synopsis of Parasites of Vertebrates. Edited by Kennedy, M.J. Alberta Agriculture, Animal Health Division. Edmonton.

Proceedings of North American Moose Conference and Workshop, 15, 303-348.

Canadian Journal of Zoology, 52, 401-403.

Joumal Wildlife Management, 33, 888-894

Canadian Journal of Zoology, 54, 307-312. the helminths of mountain goat and Rocky Mountain bighorn sheep.
Journal of Wildlife Disease, 11, 26-31

Canadian Journal of Medical Entomology, 17, 15-17.

pp. 212-225. In: Proceeding of 1st International Symposium on Mountain Goat. Samuel, W. and Macgregor, W.G. (eds.). Kalispell, MT,

February, 1977. 


\begin{tabular}{lcl}
\hline \multicolumn{1}{c}{ Author(s) / Editor } & Date & \multicolumn{1}{c}{ Title } \\
\hline $\begin{array}{l}\text { Samuel, W.M., Platt, R.R. and } \\
\text { Knispel-Krause, S.M. }\end{array}$ & 1985 & $\begin{array}{l}\text { Gastropod intermediate hosts and transmission of } \\
\text { Parelaphostrongylus odocoilei, a muscle-inhabiting } \\
\text { nematode of mule deer, Odocoileus h. hemionus, in Jasper } \\
\text { National Park, Alberta. }\end{array}$ \\
& & $\begin{array}{l}\text { Shedding of the juvenile and winter hair coats of moose } \\
\text { Samuel, W.M., Welch, D.A. and }\end{array}$ \\
\hline
\end{tabular}

Drew, M.L.

Sealy, S.G.

1963 White-tailed deer die off.

Shostak, A.W.

1980 Survival of first-stage larvae of Parelaphostrongylus odocoilei and Parelaphostrongylus tenuis (Nematoda: Metastrongyloidea).

Stelfox, J.G.

1962 Liver, lungs \& larvae - parasites and diseases in moose, deer and elk in Alberta.

Stelfox, J.G.

1963 Some common parasites in Alberta cervids.

Stelfox, J.G.

1966 Bighom disease investigation of Graveyard herd, Jasper Park, November 1 and 2, 1966.

Stelfox, J.G.

1966 Detailed data on diseased bighoms immobilized, treated and necropsied from the Radium Hot Springs and Jasper herds, Sept. 25 - Nov. 15, 1966.

Stelfox, J.G.

1967 Bighorn artificial lick problem at Miette Hot Springs, Jasper National Park, May 27 and 28, 1967.

Stelfox, J.G.

1976 Diseases and parasites of bighorn sheep in Canadian National Parks, 1966-1972.

Stock, T.M.

1978 Gastro-intestinal helminths in white-tailed deer (Odocoileus virginianus) and mule deer (Odocoileus hemionus) of Alberta: A community approach.

Stock, T.M. and Barrett, M.W.

1983 Helminth parasites of the gastro-intestinal tracts and lungs of moose (Alces alces) and wapiti (Cervus elaphus) from Cypress Hills, Alberta, Canada.

Swales, W.E.

1934 Skrabinema oreamni sp. nov., a nematode parasites of Oreamnos americanus and Rangifer sp. in Canada.

Sweatman, G.K., and Williams, J.R.

1963 Comparative studies on the biology and morphology of Echinococcus granulosus from domestic livestock, moose and reindeer.

Thorsen, J., Karstad, L., Barrett, M.W. and Chalmers, G.A.

Todd, A.W.

Trainer, D.D.

Uhazy, L.W.

1969 Lungworms and other parasites of the Rocky Mountain bighorn sheep in western Canada.

Uhazy, L.W. and Holmes, J.C.

1971 Helminths of the Rocky Mountain bighorn sheep in western Canada.

Uhazy, L.W., Holmes, J.C. and Stelfox, J.G.

Uhazy, L.W, Mahrt, J.L. and

Holmes, J.C.

1973 Lungworms in the Rocky Mountain bighom sheep of western Canada.

1971 Coccidia of Rocky Mountain bighom sheep in western Canada.

1983 Pneumonia/lungworm mortality in bighom sheep 1983.

1955 Big game parasites and diseases in the central Rocky Mountain region.

1959

Webb, R.

Wilkinson, P.R., Abbott, H.R. and 1982 Willman, J.N.
Journal / Conference / Etc.

Canadian Journal of Zoology, 63, 928-932.

Alces, 22, 345-360.

Alberta Fish and Wildlife Division, Edmonton. Unpublished report.

M.Sc. Thesis. University of Alberta, Edmonton.

Land, Forest, Wildlife, 5, 5-12.

Alberta Fish and Wildlife Division, Edmonton. Unpublished report.

Canadian Wildlife Service, Edmonton. Unpublished report.

Canadian Wildlife Service, Edmonton. Unpublished report.

Canadian Wildlife Service, Edmonton. Unpublished report.

Canadian Wildlife Service, Edmonton. Unpublished report.

M.Sc. Thesis. University of Alberta, Edmonton.

Proceedings of Helminthological Society, Washington, 50, 246-251.

Canadian Journal of Research, 10, 527-531.

Parasitology, 53, 339-390.

Journal of Wildlife Disease, 13, 74-79.

Canadian Wildlife Service, Edmonton. Unpublished report.

Journal of Wildlife Management, 28, 377-381.

M.Sc. Thesis. University of Alberta, Edmonton.

Canadian Journal of Zoology, 49, 507-512.

Canadian Joumal of Zoology, 51, 817-824.

Canadian Journal of Zoology, 49, 1461-1464.

Waterton Lakes National Park, Parks Canada, Calgary. Unpublished report.

Alberta Fish and Wildlife Division, Edmonton. Unpublished report.

Land, Forest, Wildlife, 2, 3-7.

M.Sc. Thesis. University of Alberta, Edmonton.

Canadian Field Naturalist, 96, 211-213. 
Disease/Parasites

\begin{tabular}{lclcl}
\hline \multicolumn{1}{c}{ Author(s) / Editor } & Date & Title & Journal / Conference / Etc. \\
\hline Wishart, W.D. & 1978 & $\begin{array}{l}\text { Progress report on a lungworm-pneumonia die-off of } \\
\text { bighorns of Sheep River, Alberta as of Dec. 1, 1978. }\end{array}$ & $\begin{array}{l}\text { Alberta Fish and Wildlife Division, Edmonton. } \\
\text { Unpublished report. }\end{array}$ \\
$\begin{array}{l}\text { Wishart, W.D., Jorgenson, J.T. } \\
\text { and Hilton, M. }\end{array}$ & 1980 & $\begin{array}{l}\text { A minor die-off of bighorns from pneumonia in } \\
\text { southwestern Alberta (1978). }\end{array}$ & $\begin{array}{l}\text { Proceedings of Northern Wild Sheep and Goat } \\
\text { Council, Hickey, W.O., ed., Salmon, ID. 2, }\end{array}$
\end{tabular}
229-245. 


\begin{tabular}{|c|c|c|}
\hline Author(s) / Editor & Date & Title \\
\hline Adamowicz, W.L. & 1983 & $\begin{array}{l}\text { Economic analysis of hunting of selected big game species } \\
\text { in the eastern slopes of Alberta. }\end{array}$ \\
\hline $\begin{array}{l}\text { Adamowicz, W.L. and Phillips, } \\
\text { W.E. }\end{array}$ & 1985 & An Alberta elk hunter socio-economic profile. \\
\hline Erickson, G. & 1974 & $\begin{array}{l}\text { An economic survey of deer hunting in Camp Wainwright, } \\
1973 .\end{array}$ \\
\hline Miller, R.J. & 1971 & $\begin{array}{l}\text { Alberta's hunting and fishing resource: an economic } \\
\text { evaluation. }\end{array}$ \\
\hline Pattison, W.S. & 1970 & $\begin{array}{l}\text { Economic evaluation of Alberta zone 1, moose hunting } \\
\text { activity. }\end{array}$ \\
\hline Pattison, W.S. & 1970 & $\begin{array}{l}\text { Moose hunting activity in northern Alberta: a case study in } \\
\text { wildlife economics. }\end{array}$ \\
\hline $\begin{array}{l}\text { Phillips, W., DePape, D. and } \\
\text { Ewanyk, L. }\end{array}$ & 1977 & $\begin{array}{l}\text { Socioeconomic evaluation of the recreational use of fish } \\
\text { and wildlife resources in Alberta with particular reference } \\
\text { to the Athabasca oil sands area: recreational hunting. Vol. } \\
1 \text { - summary and conclusions. }\end{array}$ \\
\hline
\end{tabular}

Phillips, W.E. and McElhaney, E.R.

Phillips, W.E. and Pattison, W.S.

Phillips, W.E. and Pattison, W.S.

Prather, R.

Recreation, Parks and Wildlife.

Snipe, J.H.

Westwood, L., Phillips, B.

Wilson, W.R.

1969

1983
1977 A socioeconomic evaluation of non-resident sport hunting activity in Alberta.

Guiding services for moose hunters in northern Alberta: an economic analysis of current and potential activity.

Hunter guiding activity in northern Alberta: wildlife economics and policy.

1974 Alternative methods of estimating benefits: an economic evaluation of big game hunting in Alberta.

1975 Socioeconomic evaluation of Alberta wildlife and recreation; a bibliography.

1970 Economics of hunting and fishing activity in southern Alberta.

Wild game utilization in Alberta, socioeconomic feasibility.
Journal / Conference / Etc.

M.Sc. Thesis. University of Alberta, Edmonton.

pp. 80-87. In: Proceedings of 1984 Western Sates and Provinces Elk Workshop. Nelson, R.W. (ed.). Edmonton, April 17-19, 1984.

Alberta Fish and Wildlife Division, Edmonton. Unpublished report.

Economics Division, Alberta Department of Agriculture, Edmonton.

Alberta Fish and Wildlife Division Edmonton. Occasional Paper No. 1.

M.Sc. Thesis. University of Alberta, Edmonton.

Prepared for the Aquatic and Terrestrial Fauna Technical Research Committees of the Alberta Oil Sands Environmental Research Program, prepared by Department of Rural Economy, University of Alberta, Edmonton.

Prepared for Alberta Fish and Wildlife Division, Edmonton; prepared by I.M.P.A.C.T. Environomics Ltd.

Prepared for Northem Alberta Development Council; prepared by Department of Agricultural Economics and Rural Sociology, University of Alberta, Edmonton.

Bulletin 14. Department of Agricultural Economics and Rural Sociology, University of Alberta, Edmonton.

M.Sc. Thesis. University of Alberta, Edmonton.

Recreation, Parks and Wildlife. Edmonton.

M.Sc. Thesis. University of Alberta, Edmonton.

Department of Rural Economy, University of Alberta, Edmonton.

Ph.D. Thesis. University of Alberta, Edmonton. 


\begin{tabular}{lll}
\hline \multicolumn{1}{c}{ Author(s) / Editor } & Date & \multicolumn{1}{c}{ Title } \\
\hline Anonymous. & 1973 & $\begin{array}{l}\text { Request for special warrant funds for the 1973-74 elk } \\
\text { damage program. }\end{array}$ \\
Anonymous. & 1976 & $\begin{array}{l}\text { Problem wildlife management. } \\
\text { Anonymous. }\end{array}$ \\
Undated & 1966 & $\begin{array}{l}\text { Antelope damage to haystacks in the Vauxhall, Alberta } \\
\text { areas. }\end{array}$ \\
Armstrong, G.G. & 1983 & $\begin{array}{l}\text { Wild and domestic ungulate interactions in the Bob Creek } \\
\text { area, southwestern Alberta. }\end{array}$ \\
Berg, B.P. & 1981 & $\begin{array}{l}\text { Elk, mule deer and cattle: functional interactions on } \\
\text { foothills range in southwestern Alberta. }\end{array}$ \\
Berg, B.P. and Hudson, R.J. & 1986 & Range and wildlife integration; The Blackfoot example. \\
Brechtel, S., and Saul, D. & 1973 & $\begin{array}{l}\text { Preliminary brief on ungulate depredation study in region } \\
1 .\end{array}$ \\
Bruns, E. & 1984 & Elk depredation of haystacks at Caroline in 1983-84. \\
\hline Bruns, E. and Shipley, C. & &
\end{tabular}

Carruthers, D.

1973 An evaluation of elk depredation problems in the Highwood area.

Eslinger, D.H., Schmidt, K.P. and 1982 Gunson, J.R.

Ewaschuk, E. and Westworth, D.A. 1983

Flook, D.R.

Fredrickson, D.R.

1975 Aspen communities and invasion of grassland in the Porcupine Hills, southwestern Alberta.

Glaholt, R.D.

1984 Availability of critical pronghorn antelope habitat in southem Alberta and its relation to land use.

Glasgow, W.

Wildlife on agricultural lands.

Glasgow, W.M.

1982 Fisheries and wildlife resources and the agricultural land base in Alberta.

Gudmundson, L

1983 An evaluation of deer population levels and related depredation problems in the Fort MacLeod area, March 1983.

Gunson, J.R., Barrett, M.W., Lyons, R.J., Sigurdson, B.V., Toney, R.T. and Winkler, M.

Gurba, J.B. and Neave, D.J.

Haig, R.W.

1986 Recent changes in cultivated lands within the pronghorn antelope range.

Hilton, J.E.

1970 Forage production and utilization in the aspen parkland of Alberta following aerial application of 2,4-D and 2,4,5-T.

Howarth, M. and Mack, T.

1982 Cypress Hills ungulate depredation survey, December 1982.

Jansson, M.C.

1970 Farmer response to depredation by wildlife on agriculture in the Athabasca area

Jebsen, L.

1979 Elk damage to pasture and cropland in southwestern Alberta.
Journal / Conference / Etc.

Alberta Fish and Wildlife Division, Edmonton. Unpublished report.

Wildlife Management Series \#9. Alberta Fish and Wildlife Division, Edmonton.

Agriculture Canada and Alberta Fish and Wildlife Division, Edmonton. Unpublished report.

Alberta Fish and Wildlife Division, Edmonton. Unpublished report.

M.Sc. Thesis. University of Alberta, Edmonton.

pp. 509-519. In: Symposium on Wildlife Livestock Relationships. University of Idaho, Boise, ID.

Alberta Fish and Wildlife Division, Edmonton Unpublished report.

Alberta Fish and Wildlife Division, Edmonton. Unpublished report.

Alberta Fish and Wildlife Division, Edmonton. Unpublished report.

Alberta Fish and Wildlife Division, Edmonton. Unpublished report.

Alberta Fish and Wildlife Division, Edmonton. Unpublished report.

Prepared for Alberta Fish and Wildlife Division, prepared by Westworth, D.A. and Associates Ltd., Edmonton. Unpublished report.

Canadian Wildlife Service, Edmonton. Unpublished report.

M.Sc. Thesis. University of Calgary, Calgary.

Masters of Environment Design Project. University of Calgary, Calgary.

pp. 116-133. In: Symposium on Fish and wildlife resources and economic development. Sponsored by the Alberta Society of Professional Biologist and Fish and Wildlife Division, Edmonton.

Environment Council of Alberta, Edmonton.

Alberta Fish and Wildlife Division, Edmonton. Unpublished report.

Alberta Energy and Natural Resources and Alberta Agriculture, Edmonton. Unpublished report.

Alberta Fish and Wildlife Division, Edmonton. Unpublished report.

Alberta Resource Evaluation and Planning Division, Edmonton. Unpublished report.

M.Sc. Thesis. University of Alberta, Edmonton.

Alberta Fish and Wildlife Division, Edmonton. Unpublished report.

M.Sc. Thesis. University of Alberta, Edmonton.

Alberta Fish and Wildlife Division, Edmonton. Unpublished report. 


\begin{tabular}{|c|c|c|}
\hline Author(s) / Editor & Date & Title \\
\hline Jebsen, $\mathbf{L}$. & 1982 & Alberta elk management problem. \\
\hline $\begin{array}{l}\text { Jensen, C.H., Smith, A.D. and } \\
\text { Scotter, G.W. }\end{array}$ & 1972 & $\begin{array}{l}\text { Guidelines for grazing sheep on rangelands used by big } \\
\text { game in winter. }\end{array}$ \\
\hline Kemp, G.A. & 1983 & $\begin{array}{l}\text { Walsh Flats pronghorn winter range options for protection } \\
\text { and management. }\end{array}$ \\
\hline Lewis, G. & 1980 & $\begin{array}{l}\text { The ecology of the grassland communities and the effects } \\
\text { of grazing in the Cypress Hill Provincial Park, Alberta. }\end{array}$ \\
\hline MacCallum, B. & 1984 & $\begin{array}{l}\text { Some wildlife and range considerations for the Clearwater, } \\
\text { upper Red Deer and Carbondale Hill (Castle River) range } \\
\text { allotments in Alberta. }\end{array}$ \\
\hline Neave, D.J. & 1970 & Land use problems on the Ya-Ha-Tinda area. \\
\hline
\end{tabular}

Norstrom, W.

Peltzer, R.

Penner, D.F.

Poll, D.M., Stelfox, J.G. and Ibach, S. (eds.)

Ransom, A.B.

Rhude, P. and Hall, W.

1978 Cattle observations in relation to deer food habits in Camp

Scotter, G.W.

Shaw, K.

Smith, H.C.

Stelfox, J.G.

1965 Big game-livestock competition potential among Grave

Stelfox, J.G.

Stelfox, J.G.

Stelfox, J.G. and Tilson, D.

Telfer, E.S.

Vriend, H.G.

Vriend, H.G.

Weatherhill, R.G. and Keith, L.B. 1969

Westworth, D.A. and Associates, 1986 Ltd.

Wig, D. Wainwright, Alberta. Flats.

A survey of ungulate depredation on agricultural crops in southern Alberta.

Livestock grazing and wildlife - is there a conflict?

Range ecology and the influence of agriculture on moose and deer range on the Smoky River breaks.

Effect of picloram on cinquefoil and forage production at the Ya-Ha-Tinda Ranch, Alberta.

Waterton Park elk.

Wildlife and fences.

Elements of controversy concerning resource exploitations of native North American ungulates populations.

Effects of livestock grazing on mixed prairie range and wildlife in PFRA pastures, Suffield Military Reserve.

Elk-livestock range interactions in the Waterton Biosphere Reserve: 1984-1985.

Impact on wildlife of land management alternatives for the Alberta east slopes.

Abundance and distribution of wild ungulates in relation to grazing intensities by livestock.

Abundance and distribution of wild ungulates and sharp-tailed grouse in relation to grazing intensities by livestock.

The effect of livestock grazing on an aspen forest community.

Jasper National Park grazing capacity study - progress report.

A survey of wild ungulate depredations in Alberta.
Journal / Conference / Etc.

Uncompleted M.Sc. Thesis. University of Alberta, Edmonton.

Journal of Range Management, 25, 346-352.

Prepared for Alberta Fish and Wildlife Division; prepared by PRISM Environmental Management Consultants.

M.Sc. Thesis. University of Calgary, Calgary.

Alberta Fish and Wildlife Division, Edmonton. Unpublished report.

Alberta Fish and Wildlife Division, Edmonton Unpublished report.

Alberta Fish and Wildlife Division, Edmonton. Unpublished report.

In: Abstracts and Papers presented at the 1977 Prairie Wildlife Habitat Conference. Brooks, April 2-4, 1977.

Alberta Fish and Wildlife Division, Edmonton. Unpublished report.

Prepared for Parks Canada, Calgary; prepared by Canadian Wildlife Service, Edmonton.

Unpublished report.

Alberta Fish and Wildlife Division, Edmonton. Unpublished report.

Alberta Fish and Wildlife Division, Edmonton. Unpublished report.

Journal of Range Management, 28, 132-138.

Park News, 17, 14-17.

Blue Jay, 30, 159-160.

Alberta Fish and Wildlife Division, Edmonton. Unpublished report.

Canadian Wildlife Service, Edmonton. Unpublished report.

Canadian Wildlife Service, Edmonton. Unpublished report.

Canadian Wildlife Service, Edmonton. Unpublished report.

Proceedings of Symposium on the Alberta Watershed Research Program.

Alberta Fish and Wildlife Division, Edmonton. Unpublished report.

Alberta Fish and Wildlife Division, Edmonton. Unpublished report.

Technical Bulletin 1. Alberta Fish and Wildlife Division, Edmonton. Unpublished report.

Prepared for Parks Canada, Calgary. Unpublished report.

Alberta Fish and Wildlife Division, Edmonton. Unpublished report. 


\begin{tabular}{|c|c|c|}
\hline Author(s) / Editor & Date & Title \\
\hline Anderson, M.L. & 1972 & $\begin{array}{l}\text { The effect of fire on grasslands in the Alberta aspen } \\
\text { parkland. }\end{array}$ \\
\hline Bailey, A.W. & 1977 & $\begin{array}{l}\text { Prescribed burning as an important tool for Canadian } \\
\text { rangelands. }\end{array}$ \\
\hline Bauer, J.A. & 1979 & $\begin{array}{l}\text { A partial bibliography of wildlife habitat manipulation with } \\
\text { emphasis on prescribed burning and manipulation and } \\
\text { results of timber management. }\end{array}$ \\
\hline Courtney, R.F. & 1986 & $\begin{array}{l}\text { The effect of burning northern mixed prairie on pronghorn } \\
\text { antelope range use. }\end{array}$ \\
\hline Courtney, R.F. & 1989 & Pronghom use of recently burned mixed prairie in Alberta. \\
\hline Davis, J.L. and Franzmann, A.W. & 1979 & $\begin{array}{l}\text { Fire-moose-caribou interrelationships: a review and } \\
\text { assessment. }\end{array}$ \\
\hline Dube, D. & 1977 & $\begin{array}{l}\text { Guidelines and operational plan for prescribed burning in } \\
\text { Elk Island National Park. }\end{array}$ \\
\hline
\end{tabular}

Geist, V.

1988 Pronghorns, fires, fossils.

Kelsall, J.P., Telfer, E.S. and Wright, T.S.

Lajeunesse, B.

1980 Pellet group counts on a burn in Elk Island National Park, 1979-1980.

Lewis, H.T.

1977 Maskuta: the ecology Indian fires in northem Alberta.

MacKenzie, G.A.

1973 The fire ecology of the forests of Waterton Lakes National Park.

Markham, B.J.

1978 Activities of the Alberta Fish and Wildlife Division in the use of fire for habitat management.

Michalsky, S.J.

1987 Prescribed crown fire effects on a subalpine bighorn sheep range at Ram Mountain, Alberta, Canada.

Novakowski, N.S.

1970 Fire priority report Wood Buffalo National Park.

Renecker, L.A.

Russell, W.

Scotter, G.W.

Scotter, G.W.

Scotter, G.W.

Stelfox, J.G. and Vriend, H.G.

Woodard, P. and Vannest
1972 Fire as an ecological factor in boreal forest ecosystems of Canada.

1976

Prairie fires and antelope use of cactus.

(in Wapiti use of prescribed burns in Elk Island National Park. prep.)

1983 A proposal for using prescribed bums to enhance ungulate winter ranges on Big Graves Flats.

1967 Effects of fire on barren-ground caribou and their forest habitat in northern Canada.

1970 Forests, fire and caribou in northern Canada.

1988 Prescribed burning bighom sheep range in winter.
Journal / Conference / Etc.

M.Sc. Thesis. University of Alberta, Edmonton.

pp. 362-381. In: Range improvement in Alberta: a literature review. University of Alberta, Edmonton.

Alberta Fish and Wildlife Division, Edmonton. Unpublished report.

M.Sc. Thesis. University of Calgary, Calgary.

J. Wildl. Manage., 53, 302-305.

Proceedings of North American Moose Conference and Workshop, 15, 80-118.

Prepared for Parks Canada, Calgary; prepared by Canadian Forestry Service, Edmonton. Unpublished report.

Alberta, 1, 202-215.

Canadian Wildlife Service Occasional Report, No. 32.

Parks Canada, Calgary. Unpublished report.

Western Canadian Journal of Anthropology, 7, 15-48.

M.Sc. Thesis. University of Calgary, Calgary,

pp. 52-55. In: Fire Ecology in Resource Management Workshop Proceedings. Environment Canada Information Report.

M.Sc. Thesis. University of Alberta, Edmonton.

Canadian Wildlife Service, Edmonton. Unpublished report.

Prepared for Parks Canada, Calgary. Unpublished report.

Alberta Fish and Wildlife Division, Edmonton. Unpublished report.

Transactions of North American Wildlife and Natural Resources Conference, 32, 246-259.

Prepared for Arctic Land Use Research Seminar, Arctic Petroleum Operators Association. Calgary, Oct. 26, 1970. Unpublished report.

In: Proceeding of Fire in the Environment. Denver, CO.

Canadian Field Naturalist, 91, 282-285.

Biennial Symposium Northern Wild Sheep and Goat Council, 6, 219-228. 


\begin{tabular}{lcl}
\hline \multicolumn{1}{c}{ Author(s) / Editor } & Date & \multicolumn{1}{c}{ Title } \\
\hline Bloomfield, M. & 1979 & $\begin{array}{l}\text { Proposal for the study of the seasonal requirements of } \\
\text { caribou in west-central Alberta and the impact of logging } \\
\text { on patterns of resource utilization. }\end{array}$ \\
$\begin{array}{l}\text { C.D. Schultz and Company } \\
\text { Limited. }\end{array}$ & 1973 & $\begin{array}{l}\text { The environmental effects of timber harvesting operations } \\
\text { in the Edson and Grande Prairie forests of Alberta. }\end{array}$ \\
Fish and Wildlife Division. & 1977 & $\begin{array}{l}\text { Perspective III: fish and wildlife aspects of the } \\
\text { environmental effects of forestry operations in Alberta. }\end{array}$ \\
Jeffrey, W.W. & 1959 & $\begin{array}{l}\text { Effect of commercial logging upon bison winter habitat in } \\
\text { the lower Peace River area. }\end{array}$
\end{tabular}

Lynch, G.M.

1971 Ungulate use of clearcuts in west-central Alberta.

Lynch, G.M.

1971 Vegetation observed on 11-year-old clear-cuts near Hinton, Alberta.

MacCallum, B., and Ebel, G.R.A. 1985

Renewable Resources Consulting Services Ltd.

Stelfox, J.G.

Stelfox, J.G.

Stelfox, J.G.

Stelfox, J.G.

Stelfox, J.G.

Stelfox, J.G.

1984 Effects of clear-cut logging and scarification on wildlife habitats in west-central Alberta

Stelfox, J.G. and Cormack, R.G.H.

1962

Stelfox, J.G., Lynch G.M., and McGillis, J.R.

Telfer, E.S.

Telfer, E.S.

Telfer, E.S.

Telfer, E.S.

1980 Potential wildlife problems in Canadian forests managed for maximum biomass production.

Tomm, H.O.

Tomm, H.O., Beck, J.A., and Hudson, R.J.

Usher, R.

1981 Responses of wild ungulates to logging practices in Alberta.

Usher, R.

1980
Journal / Conference / Etc.

Alberta Fish and Wildlife Division, Edmonton. Unpublished report.

Prepared for Lands and Forests, Government of Alberta, Edmonton. Unpublished report.

Prepared for Environment Council of Alberta.

Northern Research Unit, Forestry Branch, Department of Northern Affairs and National Resources. Unpublished report.

Alberta Fish and Wildlife Division, Edmonton. Unpublished report.

Alberta Fish and Wildlife Division, Edmonton. Unpublished report.

Prepared by MacCallum and Associates. Alberta, 275 pp.

Prepared for Alberta Fish and Game Association, Edmonton. Unpublished report.

Alberta Fish and Wildlife Division, Edmonton. Unpublished report.

Forestry Chronicle, March 1962, 94-107.

M.Sc. Thesis. Utah State University, Logan, UT.

Canadian Wildlife Service, Edmonton. 42 pp. Unpublished report.

pp. 20-51. In: Symposium on Fish and Wildlife Resources and Economic Development.

Edmonton. April 26-27, 1983.

Canadian Wildlife Service, Edmonton. 176 pp. Unpublished report.

Alberta Fish and Wildlife Division, Edmonton. Unpublished report.

Forestry Chronicle, 52, 65-70.

pp. 79-82. In: Proceedings of Symposium on Forest and Land Inventory for Management. Edmonton.

Forestry Chronicle, 186-190.

Canadian Wildlife Service, Edmonton. Unpublished report.

Paper presented at the Conference on Research on Multiple Use of Forest Resources. Flagstaff, AR. May 18-23, 1980.

M.Sc. Thesis. University of Alberta, Edmonton.

Canadian Joumal of Forestry Research, 11, 606-614

Proceedings of North American Moose Conference and Workshop, 13, 1-12.

Prepared for Esso Resources Canada Ltd., prepared by IEC International Environmental Consultants Ltd. Unpublished report. 
Effects of Hydro Development

\begin{tabular}{|c|c|c|c|}
\hline Author(s) / Editor & Date & Title & Journal / Conference / Etc. \\
\hline Bruns, E. and Markham, B.J. & 1976 & $\begin{array}{l}\text { Preliminary wildlife assessment of proposed Red Deer } \\
\text { River damsites above Sundre. }\end{array}$ & $\begin{array}{l}\text { Alberta Fish and Wildlife Division, Edmonton. } \\
\text { Unpublished report. }\end{array}$ \\
\hline $\begin{array}{l}\text { D.A. Westworth and Associates } \\
\text { Ltd. }\end{array}$ & 1982 & $\begin{array}{l}\text { An assessment of fish and wildlife use and enhancement } \\
\text { alternative for the Dickson Dam Reservoir. }\end{array}$ & $\begin{array}{l}\text { Prepared for Alberta Fish and Wildlife Division } \\
\text { and Alberta Environment, Edmonton. } \\
\text { Unpublished report. }\end{array}$ \\
\hline Dirschl, H.J. & 1971 & $\begin{array}{l}\text { Ecological effects of recent low water levels in the } \\
\text { Peace-Athabasca Delta. }\end{array}$ & $\begin{array}{l}\text { pp. 174-186. In: Proceedings of } \\
\text { Peace-Athabasca Delta Symposium. Edmonton, } \\
\text { Jan. 14-15, } 1971 \text {. }\end{array}$ \\
\hline Dirschl, H.J. & 1972 & $\begin{array}{l}\text { Evaluation of ecological effects of recent low water levels } \\
\text { in the Peace-Athabasca Delta. }\end{array}$ & $\begin{array}{l}\text { Canadian Wildlife Service, Occasional Paper No. } \\
\text { 13. Edmonton. }\end{array}$ \\
\hline $\begin{array}{l}\text { Eccles, T.R., Green, J.E., } \\
\text { Thompson, C., and Searing, G.F. }\end{array}$ & 1986 & $\begin{array}{l}\text { Slave River hydro project. Mammal studies - vol. I (Final } \\
\text { report). }\end{array}$ & $\begin{array}{l}\text { Prepared by LGL Ltd. environmental research } \\
\text { associates. Prepared for the Slave River hydro } \\
\text { project study group. Jan. } 1986 .\end{array}$ \\
\hline Larsen, D.G. & 1975 & $\begin{array}{l}\text { Preliminary assessment of impact on wildlife. Red Deer } \\
\text { River flow regulation study. }\end{array}$ & $\begin{array}{l}\text { Prepared for Planning Division, Alberta } \\
\text { Department of Environment, prepared by Alberta } \\
\text { Fish and Wildlife Division, Edmonton. } \\
\text { Unpublished report. }\end{array}$ \\
\hline LGL Ltd. Calgary, Alberta & 1986 & $\begin{array}{l}\text { Slave River hydro project mammal studies. Vol. II. Maps } \\
\text { folio (Jan. 1986). }\end{array}$ & $\begin{array}{l}\text { Prepared for the Slave River hydro project study } \\
\text { group. Prepared by LGL Ltd., Calgary, Alberta. }\end{array}$ \\
\hline Novakowski, N.S. & 1967 & $\begin{array}{l}\text { Anticipated ecological effects of possible changes in the } \\
\text { water levels of the Peace River-Athabasca River Delta as a } \\
\text { result of the damming of the Peace River. }\end{array}$ & $\begin{array}{l}\text { Canadian Wildlife Service, Edmonton. } \\
\text { Unpublished report. }\end{array}$ \\
\hline Paulsen, A. & 1975 & $\begin{array}{l}\text { An initial assessment of the downstream effects of the } \\
\text { Bighorn Dam on North Saskatchewan River wildlife } \\
\text { habitat. }\end{array}$ & $\begin{array}{l}\text { Alberta Fish and Wildlife Division, Edmonton. } \\
\text { Unpublished report. }\end{array}$ \\
\hline Snipe, J.H. & 1970 & $\begin{array}{l}\text { The ecological and economic impact of water resources } \\
\text { development in southern Alberta: the case of fish and } \\
\text { wildlife. }\end{array}$ & M.Sc. Thesis. University of Alberta, Edmonton. \\
\hline Stevens, W. & 1971 & $\begin{array}{l}\text { Ecological effects of diverting water from the Mackenzie } \\
\text { River basin to the Saskatchewan Nelson basin. }\end{array}$ & $\begin{array}{l}\text { Canadian Wildlife Service, Edmonton. } \\
\text { Unpublished report. }\end{array}$ \\
\hline Townsend, G.H. & 1971 & $\begin{array}{l}\text { Ecological assessment of the Quatre Fourches } \\
\text { impoundment. }\end{array}$ & $\begin{array}{l}\text { Canadian Wildlife Service, Edmonton. } \\
\text { Unpublished report. }\end{array}$ \\
\hline Townsend, G.H. & 1975 & Impact of the Bennett Dam on the Peace-Athabasca delta. & $\begin{array}{l}\text { Journal of Fisheries Research Board of Canada, } \\
32,171-176 .\end{array}$ \\
\hline $\begin{array}{l}\text { Westworth, D.A. and Brusnyk, } \\
\text { L.M. }\end{array}$ & 1985 & $\begin{array}{l}\text { Phase 1. Wildlife overview for the Oldman River Dam - } \\
\text { environmental mitigation/opportunities plan. }\end{array}$ & $\begin{array}{l}\text { Prepared for Alberta Environment Planning } \\
\text { Division, prepared by Westworth and Associated } \\
\text { Ltd., Edmonton. Unpublished report. }\end{array}$ \\
\hline
\end{tabular}




\begin{tabular}{lcl}
\hline Author(s) / Editor & Date & Title \\
\hline Agnew, F.N. & 1978 & Surface mining and rehabilitation in Alberta. \\
Anonymous. & 1972 & $\begin{array}{l}\text { A statement of concern by the Northern Wild Sheep } \\
\text { Council on the effects of coal mining on wild sheep } \\
\text { populations in western Canada and northwestern United } \\
\text { States. }\end{array}$
\end{tabular}

Armstrong, G.G.

1971 Coal exploration by Luscar Limited and its effect on bighorn sheep populations.

Beak Consultants Ltd.

1979 Interactions between ungulates and winter gas well drilling operations.

Bibaud, J.A.

1972 Progress report on the Athabasca tar sands area.

Brusnyk, L.M. and Westworth,

D.A.

An assessment of post-construction use of a pipeline corridor by ungulates.

Brusnyk, L.M. and Westworth,

A wildlife overview of the Soars Lake Project area.

D.A.

Brusnyk, L.M. and Westworth, D.A.

A wildlife overview of the Wabasca Project area.

Brusnyk, L.M. and Westworth, D.A.

Ungulate monitoring studies in the Coal Lake Project area.

Brusnyk, L.M. and Westworth, D.A.

Canada Department of the

Environment.

1971

Downing, D.J.

1983

Ealey, D.M. and Penner, D.F.

Etter, H. M.

Geist, V.

Holtz, A. and Reynolds, H.W.

1979 Ungulate survey and an evaluation of energy development with the Middle Sandhills and oil access areas of the Suffield Military Reserve, May 1-3, 1979.

Holtz, A. and Reynolds, H.W.

1980 Impact of drilling activities on ungulates within the Middle Sandhills of the Suffield Military Reserve. December 17, 1979 and year-end review.

Horejsi, B.

Seismic operations and their impact on large mammals: results of a monitoring program.

Hudson, R.J.

International Environmental Consultants Ltd.

Assessment of the impact of resource development on wild ungulates: a bioenergetic interpretation.

\section{Results of the Kakwa wildlife monitoring program: to establish the effects of an exploratory drilling program in the Copton Creek-Kakwa River area of Alberta.}

Coal mine development and elk biology: environmental impact assessment in Alberta and British Columbia.

Lacy, C.
Journal / Conference / Etc.

Masters of Environment Design Project. University of Calgary, Calgary.

pp. 116-117. In: Transaction of Northern Wild Sheep Council. Hinton.

Alberta Fish and Wildlife Division, Edmonton. Unpublished report.

Prepared for Mobil Oil Canada Ltd., Calgary. Unpublished report.

Alberta Fish and Wildlife Division, Edmonton Unpublished report.

Prepared for Nova, an Alberta Corporation, Environmental Affairs, Calgary; prepared by Westworth, D.A. and Associates Ltd., Edmonton. Unpublished report.

Prepared for AMOCO Canada Petroleum Ltd.; prepared by Westworth, D.A. and Associates Ltd., Edmonton: Unpublished report.

Prepared for AMOCO Canada Petroleum Ltd.; prepared by Westworth, D.A. and Associates Ltd., Edmonton. Unpublished report.

Prepared for Esso Resources Canada, Ltd.; prepared by Westworth, D.A. and Associates Ltd., Edmonton. Unpublished report.

Prepared for Obed Mountain Coal Ltd., prepared by Westworth, D.A. and Associates Lid., Edmonton. Unpublished report.

Prepared for public hearings held by the Alberta Environment Conservation Authority. Calgary, Dec, 21, 1971. Unpublished report.

M.Sc. Thesis. University of Calgary, Calgary.

Prepared for Gulf Canada Resources Inc.; prepared by McCourt Management Ltd, Calgary. Unpublished report.

Biological Conservation, 5, 191-195.

Oilweek (Calgary), 22, 12-13.

Canadian Wildlife Service, Edmonton. Unpublished report.

Canadian Wildlife Service, Edmonton. Unpublished report.

Prepared for Mobil Oil Canada Ltd. and Alberta Fish and Wildlife Division prepared by Western Wildlife Environments, Calgary. Unpublished report.

Department of Animal Science, University of Alberta, Edmonton. Unpublished report.

Final report, prepared for Esso Minerals Canada. Unpublished report.

pp. 273-282. In: North America elk: ecology, behavior and management. Boyce, M.S. and Hayden-Wing, L.D. (eds.). University of Wyoming Press, Laramie, WY.

Alberta Fish and Wildlife Division, Edmonton Unpublished report. 


\begin{tabular}{|c|c|c|}
\hline Author(s) / Editor & Date & Title \\
\hline MacCallum, B. & 1988 & $\begin{array}{l}\text { Seasonal and spatial distribution of bighom sheep at an } \\
\text { open pit mining site in the Alberta foothills. }\end{array}$ \\
\hline Markham, B.J. & 1978 & $\begin{array}{l}\text { Mitigation of the effects of petroleum development on } \\
\text { wildlife. }\end{array}$ \\
\hline Morgantini, L.E. & 1974 & $\begin{array}{l}\text { Pipeline and wildlife. A wildlife monitoring program } \\
\text { during the construction of the Hanlan-Blackstone and the } \\
\text { Brazeau pipelines. }\end{array}$ \\
\hline Morgantini, L.E. & 1981 & $\begin{array}{l}\text { Pipeline construction and wildlife. Results of a monitoring } \\
\text { program along the Edson } \mathrm{M} / \mathrm{L} \text {. First winter. }\end{array}$ \\
\hline Morgantini, L.E. & 1982 & $\begin{array}{l}\text { Pipeline construction and wildlife. Wild ungulate } \\
\text { distribution along the Grande Prairie Lateral and Elmworth } \\
\text { pipelines. One year after construction. }\end{array}$ \\
\hline Morgantini, L.E. & 1984 & $\begin{array}{l}\text { Pipeline and wildlife. A wildlife monitoring study during } \\
\text { the construction of the Hanlan and Brazeau gas pipelines. }\end{array}$ \\
\hline Morgantini, L.E. & 1985 & $\begin{array}{l}\text { Wildlife monitoring-impact mitigation in the region } \\
\text { surrounding well site 5-23. Sheep Creek-Panther River } \\
\text { area. }\end{array}$ \\
\hline Morgantini, L.E. & 1986 & $\begin{array}{l}\text { Ungulate encounters with construction materials (pipe, } \\
\text { berms, etc.) during the building of an underground gas } \\
\text { pipeline in western Alberta. }\end{array}$ \\
\hline Morgantini. L.E. & 1987 & Prairie bluff; bighorn sheep use. Fall-winter-spring. \\
\hline
\end{tabular}

\section{Morgantini, L.E.}

1991 Pipeline construction and wildlife in Alberta: impact and mitigation.

Morgantini, L.E. and Bruns, E.

1988 Attraction of bighom sheep to wellsites and other man-made mineral licks along the eastern slopes of Alberta: A management concern.

Morgantini, L.E. and Mead, D.A.

Morgantini, L.E. and Olsen, C.D.

Industrial development on prime bighorn sheep range in south-west Alberta.

Pipeline construction and wild ungulates. Results of a two year monitoring program along the Edson mainline loop.

Morgantini, L.E. and Worbets, B. 1988

Bighom sheep use of a gas wellsite during servicing and testing: a case study of impact mitigation.

Penner, D.F.

1986 Habituation of Mountain Goats to auditory stimuli prior to a seismic program at Pinto Creek, Alberta.

Penner, D.F.

1988 Behavioural response and habitation of mountain goats in relation to petroleum exploration at Pinto Creek, Alberta.

Penner, D.F. and Frandsen, D.

1981 Wildlife impact assessment - Brazeau River sour gas plant. Preliminary draft report.

Penner, D.F., Duncan, J.A. and Jalkotzy, P.S.

1983 Monitoring of a geophysical exploration program and its effect on woodland caribou and other wildlife near Manning, Alberta.

Prism Environmental Management Consultants Ltd.

Renewable Resources Consulting Services Ltd.

Revel, R.D., Dougherty, T.D. and Downing, D.J.

Roe, N.A.

Ryhanen, H.M. and Jenkins, R.D. 1969 construction of the Grande Prairie lateral and Elmworth loop pipelines.

Coal strip mining restoration experiment at Sterco and
Journal / Conference / Etc.

Biennial Symposium Northern Wild Sheep and Goat Council, 6, 106-120.

Paper presented at P.I.T.S. Environmental Lease Management Seminar. Hinton, June 12-26, 1978.

Prepared for Canterra Energy Ltd., prepared by Wildland Resources Consultants. Edmonton. Unpublished report.

Prepared for Nova corporation. Prepared by Wildland Resources Consultants. 107 pp.

Prepared for Nova Corporation. Prepared by Wildland Resources Consultants. 91 pp.

Prepared for Canterra Energy Limited. Prepared by Wildland Resources Consultants. 58 pp.

Interim report prepared for Canterra Energy Ltd. (now known as Husky Oil Ltd., Calgary).

Prepared by Wildlife Resources Consulting Ltd., Edmonton. $30 \mathrm{pp}$.

Alces, 21, 215-230.

Prepared for Shell Canada Ltd., prepared by Wildland Resources Consulting Ltd., Edmonton. Unpublished report.

Inter. Symposium on Cold Region Development. Edmonton, Alberta.

pp. 135-140. In: Proceedings of the Biennial Wild Sheep and Goat Council. Banff.

Proceedings of the Biennial Symposium of the Northem Wild Sheep and Goat Council. (in press).

Report prepared for NOVA, an Alberta Corporation. Prepared by Wildland Resources Consultants, Edmonton. Fish and Wildlife Files, Edmonton. 174 pp.

Biennial Symposium of Northern Wild Sheep and Goat Council, 6, 159-164.

Alberta Fish and Wildlife Division, Edmonton. Unpublished Report.

Biennial Symposium Northern Wild Sheep and Goat Council, 6, 141-158.

Prepared for Petro Canada. Prepared by McCourt Management Ltd., Calgary. Unpublished report.

Prepared for Husky Oil Operations Ltd.; prepared by McCourt Management Ltd., Calgary. Unpublished report.

Prepared for the Canadian Petroleum Association, Calgary. Unpublished report.

Prepared for Alberta Fish and Game Association, Edmonton. Unpublished report.

University of Calgary Press, Calgary.

Prepared for Nova, An Alberta Corporation, Calgary; prepared by Environmental Management Associates, Calgary. Unpublished report. Lovett. Edson Forest-1968.
Alberta Fish and Wildlife Division, Edmonton. Unpublished report. 
Effects of Petrochemical Industry

\begin{tabular}{|c|c|c|c|}
\hline Author(s) / Editor & Date & Title & Journal / Conference / Etc. \\
\hline Smith, K. & 1982 & $\begin{array}{l}\text { An evaluation of the impact of petroleum activity on } \\
\text { ungulate distribution in Twp. } 52 \text { - Rge. } 14 \text { - W5M. }\end{array}$ & $\begin{array}{l}\text { Alberta Fish and Wildlife Division, Edmonton. } \\
\text { Unpublished report. }\end{array}$ \\
\hline Smith, K. and Bloomfield, M. & 1980 & $\begin{array}{l}\text { Strategy for elk management during a period of intense oil } \\
\text { and gas activity. }\end{array}$ & $\begin{array}{l}\text { Paper presented at Elk Management Workshop. } \\
\text { Cranbrook, BC. }\end{array}$ \\
\hline Stelfox, J.G. & 1965 & $\begin{array}{l}\text { Hudson Bay oil well H25 escape and potential wildlife kill } \\
\text { in Section 17, Township 58, Range 19, West 5th Meridian } \\
\text { north of Marlboro. }\end{array}$ & $\begin{array}{l}\text { Alberta Fish and Wildlife Division, Edmonton. } \\
\text { Unpublished report. }\end{array}$ \\
\hline Stubbs, B. & 1980 & Integrating wildlife and petroleum activity. & Canadian Wildlife Administration, 6, 8-9. \\
\hline Tennessen, $\mathrm{T}$. & 1979 & $\begin{array}{l}\text { Psychological aspects of wildlife harassment: with an } \\
\text { analysis of the responses of ungulates to geophysical } \\
\text { exploration. }\end{array}$ & $\begin{array}{l}\text { Alberta Fish and Wildlife Division, Edmonton. } \\
\text { Unpublished report. }\end{array}$ \\
\hline $\begin{array}{l}\text { Thompson, D.C., Ealey, D.M. and } \\
\text { McCourt, K.H. }\end{array}$ & 1980 & $\begin{array}{l}\text { A review and assessment of the baseline data relevant to } \\
\text { the impacts of oil sands developments on large mammals } \\
\text { in the AOSERP study area. }\end{array}$ & $\begin{array}{l}\text { Prepared for the Alberta Oil Sands Environmental } \\
\text { Research Program; prepared by McCourt } \\
\text { Management Ltd., Calgary. Unpublished report. }\end{array}$ \\
\hline
\end{tabular}




\begin{tabular}{lcl}
\hline \multicolumn{1}{c}{ Author(s) / Editor } & Date & \multicolumn{1}{c}{ Title } \\
\hline Butler, J.R. & 1979 & $\begin{array}{l}\text { Current trends in wildlife recreational benefits and their } \\
\text { relationship to the private landowner. }\end{array}$ \\
$\begin{array}{l}\text { Cornish, B., Van Camp, J. and } \\
\text { McNicholl, M. }\end{array}$ & 1980 & $\begin{array}{l}\text { The impacts of recreation on fish and wildlife with } \\
\text { emphasis on Kananaskis Country: a literature review and } \\
\text { partial bibliography. }\end{array}$ \\
Didrikson, R. & 1977 & $\begin{array}{l}\text { The effects of disturbance on the activity parterns, energy } \\
\text { budgets and productivity of wapiti. }\end{array}$ \\
Didrikson, R. & 1978 & $\begin{array}{l}\text { Final report on disturbance study at Elk Island National } \\
\text { Park. }\end{array}$ \\
Dorrance, M.J., Savage, P.J. and & 1975 & Effects of snowmobiles on white-tailed deer.
\end{tabular}

Huff, D.E.

Fardoe, B.K.

1982

Ferguson, M.A.D.

1980 Ungulates and cross-country skiing, Elk Island National Park, Alberta.

Ferguson, M.A.D. and Keith, L.B. 1982

Fitzmartin-Harrison, G.A.

1979 Impact and recovery of horse supported group camps in Banff National Park, Alberta.

Geist, V.

1983 Bighorn sheep herd threatened by winter Olympics.

Herrero, S.

1970 New developments proposed for Canada's Rocky Mountain National Parks.

Horejsi, B.

1976 Some thoughts and observations of harassment and bighorn sheep.

Jonker, P.M.

1984 Snowmobilers, their experience and habitat preferences, and the implications for wintering moose in McLean Creek area, Alberta.

Jorgenson, J.

1988 Environmental impact on the Mount Allan bighorn sheep herd - the Olympics story.

MacArthur, R.A., Geist, V. and Johnston, R.A.

1982 Cardiac and behavioural responses of mountain sheep to human disturbances.

Marshall, W.J.

1978 Planning for winter recreation use: a case study of Elk Island National Park.

McCallum, M., Lewis, C. and Wakelyn, L.

1984 Potential impacts of the proposed Mount Allan ski facility on wildlife resources and proposed mitigation.

Morgantini, L.E.

1978 Ecology and behavior of the Banff Ya-Ha-Tinda elk herd and the effects of harassment.

Morgantini, L.E. and Hudson, R.J. 1979 Human disturbance and habitat selection in elk.

Penner, D.F. and Jalkotzy, P.S. 1984 Ecological and behavioural studies on mountain goats at Pinto Creek, Alberta. Part I. Ecological studies. Part II. Behavioural disturbance studies. Part III. Impact assessment.

Roe, N.A. and Shackleton, D.M. 1984 Wildlife impact mitigation measures for the Mount Allan draft master plan.

Scotter, G.W.

1975 Forage production and impact of horses in Tonquin Valley, Jasper National Park.

Stace-Smith, R.

Stelfox, J.G. and Bindernagel, J.A. 1978

Trottier, G.C.

1975 An assessment of horse grazing impact in Brewster Creek Valley, Banff National Park.
Journal / Conference / Etc.

Paper presented at the 43rd Federal Provincial Wildlife Conference. Regina, SK.

Alberta Fish and Wildlife Division, Edmonton. Unpublished report.

Alberta Fish and Wildlife Division, Edmonton. Unpublished report.

Alberta Fish and Wildlife Division, Edmonton. Unpublished report.

Joumal of Wildlife Management, 39, 563-569.

Masters of Environmental Design Project. University of Calgary, Calgary.

M.Sc. Thesis. University of Wisconsin, Madison, WI

Canadian Field Naturalist, 96, 69-78.

M.Sc. Thesis. University of Calgary, Calgary.

Bulletin of Canadian Society of Zoologists, 14, 13-14.

Canadian Field Naturalist, 84, 333-342.

pp. 149-155. In: Proceedings of the Biennial Symposium of the Northern Wild Sheep Council. Jackson, WY.

M.Sc. Thesis. University of Calgary, Calgary.

Biennial Symposium Northern Wild Sheep and Goat Council, 6, 121-134.

Journal of Wildlife Management, 46, 351-358.

M.Sc. Thesis. University of Calgary, Calgary.

Alberta Fish and Wildlife Division, Edmonton. Unpublished report.

Alberta Fish and Wildlife Division, Edmonton. Unpublished report.

pp. 132-139. In: North American elk: ecology, behavior and management. Boyce, $\mathbf{M}$. and Hayden-Wing, L. (eds.). University of Wyoming, Laramie, WY.

Prepared for Gulf Canada Resources Inc., prepared by McCourt Management Ltd., Calgary. Unpublished report.

Prepared for the Landplan Group, Calgary; prepared by Environmental Management Associates, Calgary. Unpublished report.

Canadian Wildlife Service, Edmonton. Unpublished report.

Naturaliste Canadien, 4, 3-8.

Canadian Wildlife Service, Edmonton. Unpublished report.

Canadian Wildlife Service, Edmonton. Unpublished report. 
Effects of Recreational Activities

\begin{tabular}{lclll}
\hline \multicolumn{1}{c}{ Author(s) / Editor } & Date & Title & Journal / Conference / Etc. \\
\hline Trottier, G.C. and Scotter, G.W. & 1975 & $\begin{array}{l}\text { Backcountry management studies, the Egypt Block, Banff } \\
\text { National Park. }\end{array}$ & $\begin{array}{l}\text { Canadian Wildlife Service, Edmonton. } \\
\text { Unpublished report. }\end{array}$ \\
$\begin{array}{l}\text { Yarmaloy, C.P. } \\
\text { Yarmaloy, C.P., Bayer, M. and }\end{array}$ & 1984 & $\begin{array}{l}\text { The impact of off-highway vehicles on big game: } \\
\text { management implications for Alberta's eastem slopes. }\end{array}$ & $\begin{array}{l}\text { Master of Environmental Design Project. } \\
\text { University of Calgary, Calgary. }\end{array}$ \\
$\begin{array}{l}\text { Geist, V. } \\
\text { Behavior responses and reproduction of mule deer, } \\
\text { Odocoileus hemionus, does following experimental } \\
\text { harassment with an all-terrain vehicle. }\end{array}$ & Canadian Field Naturalist, 102, 425-429.
\end{tabular}


Effects of Settlements

\begin{tabular}{lcl}
\hline \multicolumn{1}{c}{ Author(s) / Editor } & Date & \multicolumn{1}{c}{ Title } \\
\hline Bergerud, A.T. & 1974 & Decline of caribou in North America following settlement. \\
Geist, V. & 1980 & Downtown deer. \\
McFetridge, R.J. & 1977 & $\begin{array}{l}\text { Tawatinaw Valley residential development: wildlife impact } \\
\text { and recommendations. }\end{array}$ \\
& & \\
McFetridge, R.J. & 1977 & $\begin{array}{l}\text { Wildife versus country residential subdivisions - are there } \\
\text { any solutions? }\end{array}$ \\
& & Some effects of settlement on wildlife in Alberta. \\
Rowan, W. & 1952 & Sol
\end{tabular}

Journal / Conference / Etc.

Journal of Wildlife Management, 38, 757-770.

Natural History, 89, 56-64.

Prepared for Alberta Municipal Affairs, Regional Planning Section, Planning Services Division and County of Athabasca; prepared by Alta. Fish and Wildlife Division, Edmonton. Unpublished report.

In: Abstracts and Papers presented at the 1977 Prairie Habitat Conference. Brooks, April 2-4. 1977.

Transactions of the Canadian Conservation Association. Quebec City, PQ. June 5. 1952. 


\begin{tabular}{|c|c|c|}
\hline Author(s) / Editor & Date & Title \\
\hline Bottini, M. & 1987 & Elk roadkills on the Trans Canada Highway. \\
\hline Bottini, M. & 1987 & $\begin{array}{l}\text { Initial effects of highway fencing and wildlife underpas } \\
\text { on elk movement and behavior in Banff National Park. }\end{array}$ \\
\hline $\begin{array}{l}\text { Bottini, M., Flygare, H. and } \\
\text { Woods J.G. }\end{array}$ & 1986 & $\begin{array}{l}\text { Twenty-four hour relocations and observation of elk in } \\
\text { Phase I and Phase II. }\end{array}$ \\
\hline Bradford, W. & 1988 & $\begin{array}{l}\text { A plan to reduce wildlife mortality on transportation } \\
\text { conridors in Jasper National Park. }\end{array}$ \\
\hline Bradford, W. and Phillips, I. & 1986 & Ungulate mortalities (highway and railroad) 1980-1986 \\
\hline Browne, B. & 1984 & $\begin{array}{l}\text { First interim report for the wildlife study along the Bow } \\
\text { Valley from Sunshine turn-off to Castle junction - TCH } \\
\text { twinning phase III. }\end{array}$ \\
\hline
\end{tabular}

Browne, B.

Bruns, E.H.

Bunyan, R.

Clarkson, P.

1991

Damas and Smith Ltd.

1981 Wildlife mortality in transportation corridors in Elk Island National Park.

Damas and Smith Ltd

1983 Wildlife mortality in transportation corridors in Canada's National Parks. Vols. 1 and 2.

EVDS.

1984 A review of the Banff highway project. Project for the course Impact Assessment, EVDS 649.

Flaa, J.

Flygare, H.

Flygare, H.

Flygare, $\mathrm{H}$.

Flygare, H.

Flygare, H.

Harrison, G., Hooper, R. and Jacobson, P.

Harrison, G., Hooper R. and Jacobson, P.

Holroyd, G.L.

1980 Trans-Canada highway - wildlife mitigating measures, Banff National Park.

1982 TCH ungulate population statistics, Banff National Park (east gate to Sunshine turnoff).

1979 The impact of highway and railroad mortality on the ungulate populations in the Bow Valley, Banff National Park.

Hunt, C.E.

Jakimchuk, R.D. and Sopuk, L.G. 1987

Klenavic, J.S.

Kunelius, R.

1988

A review of wildlife research and mitigation programs for the Banff twinning project.

Banff Highway project (East Gate to kilometer 13). Report of the Environmental Assessment Panel.

Concerns relating to the further fencing of the Trans
Journal / Conference / Etc.

Department of Forestry, University of B.C.

Department of Forestry, University of B.C.

Parks Canada, Calgary. Unpublished report.

Parks Canada, Calgary. Unpublished report.

Jasper National Park, Parks Canada, Calgary. Unpublished report.

Parks Canada, Calgary. Unpublished report.

Parks Canada, Calgary. Unpublished report.

Alberta Fish and Wildlife Division, Edmonton Unpublished report.

Resource Conservation, Parks Canada, Calgary. Unpublished report.

Parks Canada, Calgary. Unpublished report.

Prepared for Parks Canada, Calgary. Prepared by Damas and Smith Ltd. Unpublished report.

Prepared for Parks Canada, Calgary. Prepared by Damas and Smith Ltd. Unpublished report.

Faculty of Environment Design, University of Calgary, Calgary.

Parks Canada, Calgary. Unpublished report.

Banff National Park, Parks Canada, Calgary. Unpublished report.

Parks Canada, Calgary. Unpublished report.

Banff National Park, Parks Canada, Calgary. Unpublished report.

Parks Canada, Calgary. Unpublished report.

Parks Canada, Calgary. Unpublished report.

Parks Canada, Calgary. Unpublished report.

Parks Canada, Calgary. Unpublished report.

Canadian Wildlife Service, Edmonton. Unpublished report.

M.Sc. Thesis. University of Calgary, Calgary. Canada highway through Banff National Park.
Renewable Resources Consulting services.

Federal Environment Assessment and Review Process II.

Report for public works Canada. Parks Canada, Calgary. Unpublished report. 


\begin{tabular}{ccc}
\hline Author(s) / Editor & Date & Titie \\
\hline Leeson, B.F. and Allan G.G. & 1987 & The Banff highway: Pleasing the park
\end{tabular}

Leighton, D.

1988

Lindahl, $\mathbf{M}$.

1982

Loewen, A.

Logan, S.

Lombard North Group

Lombard North Planning Ltd.

Markham, B.J.

1976 Grande Prairie-Grande Cache transportation study. Wildlife report.

Martin, D.J.

1974 Wildlife mortality statistics, highway and railway causes, Jasper National Park 1966-1973.

Olson, W.

1984 Justification for wildlife underpass $\mathrm{km} \mathrm{18,} \mathrm{T.C.H.}$

Paradine, P.J.

Potolicki, G.D.

1987 Monitoring of animal kills on CN twin track within Jasper National Park, report \#3.

Public Works Canada.

1981 Preliminary design report on the twinning of the Trans Canada Highway in Banff National Park, $\mathrm{Km} 0$ to 6.2.

Public Works Canada

1981 Principles and details of animal fencing and crossing structures proposed for Trans Canada Highway Twinning, Banff National Park.

Reed, D.F., Woodward, T.N. and Pojar, T.M.

Reid Crowther and Partners.

Rimek, S.G.

Ross, W.A.

Sanderson, K.

1983

Scott-Brown, J.M.

1984 Ungulate monitoring along the Trans-Canada highway, Banff National Park.

Smith, B.

1983 Wildlife mitigation measures TCH phase I contingency plan for wildlife intrusions into the highway right-of-way.

Smith. G. and Villamere, J. 1985 Chinamans Creek diversion project, 1984 status report.

Sopuk, L.G. and Jalimuchuk, J.D. 1988 A review of the wildlife mitigation options for phase III of the Banff highway twinning project.

Surrendi, C.

Surrendi, C.

1984

Preliminary report on wildlife mortality along C.N. right of way and observations on habitat quality in Jasper National Park.

Monitoring of animal kills on the C.N. twin track, Jasper National Park, report \#2.

Van Tighem, $\mathrm{K}$.

1980 Environment impact of Canadian National Railways twinning on large mammals east of Jasper, Alberta.

Van Tighem, $K$.

1981 Mortality of bighom sheep (Ovis canadensis) on a railroad and highway in Jasper National Park, Canada.
Journal / Conference / Etc.

pp. 48-52. In: Parkways: Past, present and future. Proceedings of the second Biennial Linear Parks Conference. Appalachian Consortium Press, Boone, North Carolina.

Canadian Geographic Journal, 108, 22-28.

International Wildlife, 12, 29-31.

Jasper National Park, Parks Canada, Calgary. Unpublished report.

Parks Canada, Calgary. Unpublished report. Effects of Transportation

Prepared for Parks Canada, Calgary.

Prepared for Department of Public Works, Western Region, Calgary. Unpublished report

Alberta Fish and Wildlife Division, Edmonton. Unpublished report.

Jasper National Park, Parks Canada, Calgary. Unpublished report

Parks Canada, Calgary. Unpublished report.

Federal Environmental Assessment and Review Process report 18.

Prepared by Canadian National Environmental Supervisor, Edmonton. Unpublished report.

Parks Canada, Calgary. Unpublished report.

Public Works Canada, Parks Canada, Calgary. Unpublished report.

Journal of Wildlife Management, 39, 361-367.

Prepared for Public Works Canada, Parks Canada, Calgary. Unpublished report.

Department of Geography, University of Manitoba.

Report for the Federal Environmental Assessment Review Office.

Environment Council of Alberta, Edmonton.

Masters of Environmental Design Project.

University of Calgary, Calgary.

Parks Canada, Calgary. Unpublished report.

Prepared for Parks Canada, Calgary. Prepared by Hatfield Consultants Ltd.

Prepared for Public Works Canada. Prepared by Renewable Resources Consulting Services Ltd. Sidney, B.C.

Prepared for Canadian National, Edmonton; prepared by Carsal Enterprises Ltd., Edmonton. Unpublished report.

Prepared for Canadian National, Edmonton; prepared by Carsal Enterprises Lid., Edmonton. Unpublished report.

Canadian Wildlife Service, Edmonton.

Canadian Wildlife Service, Edmonton. Unpublished report. 


\begin{tabular}{|c|c|c|c|}
\hline Author(s) / Editor & Date & Title & Journal / Conference / Etc. \\
\hline Waters, D. & 1988 & $\begin{array}{l}\text { Final report - monitoring program mitigative measures, } \\
\text { Trans Canada highway twinning, } \mathrm{km} 0-11.4 \text {. }\end{array}$ & Parks Canada, Calgary. Unpublished report. \\
\hline Woods, J.G. & 1986 & $\begin{array}{l}\text { Methodologies: Effectiveness of fences and underpasses } \\
\text { on the Trans Canada highway and their impact on ungulate } \\
\text { populations. }\end{array}$ & Parks Canada, Calgary. Unpublished report. \\
\hline Woods, J.G. & 1987 & $\begin{array}{l}\text { Bow Valley elk population characteristics 1985-1987: a } \\
\text { discussion paper and example computer simulation of the } \\
\text { impact of the Banff highway project. Draft report. }\end{array}$ & Parks Canada, Calgary. Unpublished report. \\
\hline Woods, J.G. & 1987 & $\begin{array}{l}\text { Effectiveness of fences and underpasses on the Trans } \\
\text { Canada highway and their impact on ungulate populations } \\
\text { project, first project report, September } 1985 \text { to December } \\
1986 .\end{array}$ & Parks Canada, Calgary. Unpublished report. \\
\hline Woods, J.G. & 1988 & $\begin{array}{l}\text { Second progress report, effectiveness of fences and } \\
\text { underpasses on the Trans Canada highway and their } \\
\text { impact on ungulate population. }\end{array}$ & $\begin{array}{l}\text { Natural History Research Division, Parks } \\
\text { Canada, Calgary. Unpublished report. }\end{array}$ \\
\hline Woods, J.G. & 1990 & $\begin{array}{l}\text { Effectiveness of fences and underpasses on the } \\
\text { Trans-Canada Highway, and their impact on ungulate } \\
\text { populations project }\end{array}$ & Canadian Parks Service report. \\
\hline $\begin{array}{l}\text { Woods, J.G., Browne, B. and } \\
\text { Waters, D. }\end{array}$ & 1988 & $\begin{array}{l}\text { Initial effects of highway expansion and fencing on elk } \\
\text { mortalities and movements in Banff National Park, } \\
\text { Alberta. }\end{array}$ & Proceedings of Elk workshop. \\
\hline
\end{tabular}




\begin{tabular}{lrl}
\hline \multicolumn{1}{c}{ Author(s) / Editor } & Date & \\
\hline Bayrock, L.A. & 1966 & Bison in Alberta. \\
Bayrock, L.A. and Hillerud, J.M. & 1964 & New data on Bison bison athabascae Rhoads. \\
Churcher, C.S. & 1968 & $\begin{array}{l}\text { Pleistocene ungulates from the Bow River gravels at } \\
\text { Cochrane, Alberta. }\end{array}$ \\
Churcher, C.S. & 1975 & $\begin{array}{l}\text { Additional evidence of Pleistocene ungulates from the Bow } \\
\text { River gravels at Cochrane, Alberta. }\end{array}$ \\
Churcher, C.S. and Wilson, M. & 1979 & $\begin{array}{l}\text { Quaternary mammals from the eastern Peace River district } \\
\text { Alberta. }\end{array}$ \\
Fox, R.C. & 1968 & $\begin{array}{l}\text { A new Paleocene mammal (Condylarthra: Arctocyonidae) } \\
\text { from a wall in Alberta, Canada. }\end{array}$ \\
Fuller, W.A. and Bayrock, L.A. & 1965 & $\begin{array}{l}\text { Late Pleistocene mammals from central Alberta, Canada. } \\
\text { Geist, V. }\end{array}$ \\
Geist, V. & 1966 & $\begin{array}{l}\text { On the behaviour and evolution of American mountain } \\
\text { sheep. }\end{array}$ \\
Geist, V. & 1966 & $\begin{array}{l}\text { The evolutionary significance of mountain sheep horns. } \\
\text { The relation of social evolution and dispersal in ungulates } \\
\text { during the Pleistocene, with emphasis on the Old World } \\
\text { deer and the genus Bison. }\end{array}$ \\
\hline
\end{tabular}

Geist, V.

1972 On the relationship of ecology and behavior in the evolution of ungulates: theoretical considerations.

Geist, V.

1974 On the relationship of social evolution and ecology in ungulates.

Geist, V.

1983 On the evolution of ice age mammals and its significance to an understanding of specializations.

Geist, V.

1985 On Pleistocene bighorn sheep: some problems of adaptation, and its relevance to today's American megafauna.

Geist, V.

1986 The paradox of the great Irish stags.

Geist, V.

1987 On speciation in Ice Age mammals, with special reference to Cervus and caprids.

Geist, V.

1987 On speciation in Ice Age mammals with special reference to deer and sheep.

Geist, V.

1987 On the evolution and adaptations of Alces.

Geist, V.

Geist, V.

1988 "Periglacial ecology, large mammals and their significance to human biology.

Geist, V. and Karsten, P.

1977 The wood bison (Bison bison athabascae, Rhoads) in relation to hypotheses on the origin of the American bison (Bison bison Linnaeus).

Harington, C.R.

1975 Pleistocene muskoxen (Symbos) from Alberta and British Columbia.

Hillerud, J.M.

Millar, W.N.

Research Council of Alberta.

Bison occidentalis lucas found at Taber, Alberta, Canada.

Shackleton, D.M. and Hills, L.V.
Journal / Conference / Etc.

Archaeological Society of Alberta Newsletter, Spring, 8(1-3).

Journal of Mammalogy, 45, 630-632.

Canadian Journal of Earth Science, 5, 1467-1488

Canadian Journal of Earth Science, 12, 68-76.

Journal of Paleontology, 53, 71-76.

Journal of Mammalogy, 49, 661-664

pp. 53-63. In: Vertebrate paleontology in Alberta. University of Alberta, Edmonton.

$\mathrm{Ph} . \mathrm{D}$. Thesis. University of British Columbia, Vancouver, British Columbia.

Evolution, 20, 558-566.

Quaternary Research 1, 285-315.

pp. 234-246. In: The behavior of ungulates and its relation to management. Geist, V. and Walther, F. (eds.). IUCN, Switzerland.

American Zoologist, 14, 205-220.

Bulletin Association of Southern Biologists, 30, 109-13.3.

Wildlife Society Bulletin, 13, 351-359.

Natural History, 95, 54-64.

Canadian Journal of Zoology, 65, 1035-1038.

Canadian Journal of Zoology, 65, 1067-1184.

Swedish Wildlife Research Supplement, 1, 11-23.

pp. 235-255. In: C.M. Wenner (ed.)

Proceedings Symposium, The significance of ice-marginal environments in biological and cultural evolution. 23rd NE section meeting, Geological Society of America, Portland, Main, U.S.A., March 10-12, 1988.

Z. Saugetierk., 42, 119-127.

Canadian Journal of Earth Science, 15, 903-919.

M.Sc. Thesis. University of Nebraska, Lincoln, NE.

pp. 100-124. In: Conservation of fish, bids, and game. Proceedings of Committee Meeting, Nov. 1-2, 1916. The Methodist Book and Publishing House, Toronto, ON.

Edmonton, Alberta. Unpublished report.

Alberta Conservation, 1, 14-16. 
Evolution/Palaeontology

\begin{tabular}{lclll}
\hline \multicolumn{1}{c}{ Author(s) / Editor } & Date & \multicolumn{1}{c}{ Title } & Journal / Conference / Etc. \\
\hline Shackleton, D.M. and Hills, L.V. & 1977 & $\begin{array}{l}\text { Post-glacial ungulates (Cervus and Bison) from Three } \\
\text { Hills, Alberta. }\end{array}$ & Canadian Journal of Earth Science, 14, 963-986. \\
Spry, I.M. & 1963 & The Palliser expedition 1857-1860. & MacMillan Co. of Canada Ltd., Toronto, ON. \\
Wilson, M.C. & 1974 & $\begin{array}{l}\text { Fossil bison and artifacts from the Mona Lisa site, } \\
\text { Calgary, Alberta. Part 1: stratigraphy and artifacts. }\end{array}$ & Plains Anthropologist, 19, 34-45. \\
Wilson, M.C. and Hills, L.V. & 1984 & $\begin{array}{l}\text { Holocene white-tailed deer (Odocoileus virginianus) from } \\
\text { the foothills northwest of Calgary, Alberta, Canada. }\end{array}$ & Canadian Journal of Earth Science, 21, 365-370.
\end{tabular}




\begin{tabular}{|c|c|c|}
\hline Author(s) / Editor & Date & Title \\
\hline Allan, D. & 1988 & $\begin{array}{l}\text { Wildlife census of Rocky Mountain bighorn sheep in } \\
\text { Jasper National Park. }\end{array}$ \\
\hline Anonymous. & 1971 & Elk census 1971, Waterton Lakes National Park. \\
\hline Anonymous. & 1975 & Bison surveys, October 1974 to October 1975. \\
\hline Banfield, A.W.F. & 1952 & $\begin{array}{l}\text { Aerial survey of game winter ranges, Banff National Park } \\
1952 \text {. }\end{array}$ \\
\hline Banfield, A.W.F. & 1953 & $\begin{array}{l}\text { Aerial survey of game winter ranges, Banff and Jasper } \\
\text { National Parks, } 1953 \text {. }\end{array}$ \\
\hline Blood, D.A. & 1962 & $\begin{array}{l}\text { Aerial big game census, Elk Island National Park, } \\
\text { December, } 1961 \text {. }\end{array}$ \\
\hline Blood, D.A. & 1964 & $\begin{array}{l}\text { Aerial census of ungulates, Elk Island National Park, } \\
\text { November } 1963 \text { and January } 1964 .\end{array}$ \\
\hline Blood, D.A. & 1965 & $\begin{array}{l}\text { Aerial survey of Canadian Wildlife Service study area and } \\
\text { part of the isolation area, Elk Island National Park, March } \\
1965 .\end{array}$ \\
\hline Blood, D.A. & 1966 & $\begin{array}{l}\text { Aerial census of ungulates, Elk Island National Park, } \\
\text { winter 1965-66. }\end{array}$ \\
\hline Bradford, W. & 1986 & Wildlife monitoring program - Jasper National Park. \\
\hline Bradford, W. & 1987 & $\begin{array}{l}\text { Report on } 1987 \text { aerial survey and analysis of mountain } \\
\text { sheep (Ovis canadensis) population trends in Jasper } \\
\text { National Park. }\end{array}$ \\
\hline Bradford, W. & 1991 & $\begin{array}{l}\text { Report on the } 1991 \text { aerial census of elk along the east } \\
\text { transportation corridor of Jasper National Park. }\end{array}$ \\
\hline Brady, K.W. & 1978 & Elk pellet group study, Waterton Lakes National Park. \\
\hline Buker, J. & 1986 & $\begin{array}{l}\text { Caribou monitoring project, Sunwapta district, Jasper } \\
\text { National Park. }\end{array}$ \\
\hline Buker, J. & 1987 & $\begin{array}{l}\text { Caribou monitoring project, Sunwapta district, Jasper } \\
\text { National Park. }\end{array}$ \\
\hline Christiansen, J.M. & 1971 & $\begin{array}{l}\text { Ungulate distribution survey, spring and fall periods, } \\
\text { ground survey, Waterton Lakes National Park. }\end{array}$ \\
\hline Christiansen, J.M. & 1972 & $\begin{array}{l}\text { Aerial survey of ungulates in Waterton Lakes National } \\
\text { Park. }\end{array}$ \\
\hline Christiansen, J.M. & 1972 & Ungulate distribution project $1971-72$. \\
\hline
\end{tabular}

Cooper, S.

1975 Secondary winter bison ranges survey, February, 1975, Wood Buffalo National Park.

Couchie, D.G. and Loranger, R.J. 1979 Total bison counts, February 1979.

Damm, T.

1988 Sunwapta caribou monitoring project $1987-88$, progress report.

Eder, $\mathbf{M}$.

1989 Caribou monitoring in the Blue Creek Valley, Jasper National Park.

Eder, $\mathbf{M}$.

1990 Caribou monitoring in the Blue Creek Valley, Jasper National Park.

Flook, D.R.

Big game survey, south-east Jasper Park, summer 1955.

Flook, D.R.

1956 Elk and bighom sheep, Waterton Lakes Park.

Flook, D.R.

1959 Helicopter survey of big game, Elk Island National Park, February 17, 1959.

Flook, D.R.

1960 Aerial game inventory, Elk Island National Park, February 1960.

Flook, D.R. and McGillis, J.R.
1968 Aerial count of moose, elk and deer, Elk Island National Park, December 11-13, 29 and 30, 1967.
Journal / Conference / Etc.

Parks Canada, Calgary. Unpublished report.

Parks Canada, Calgary. Unpublished report.

Wood Buffalo National Park, Parks Canada, Calgary. Unpublished report.

Canadian Wildlife Service, Edmonton. Unpublished report.

Canadian Wildlife Service, Edmonton. Unpublished report.

Canadian Wildlife Service, Edmonton. Unpublished report.

Project M1-1-4. Canadian Wildlife Service, Edmonton. Unpublished report.

Canadian Wildlife Service, Edmonton. Unpublished report.

Project M1-1-4. Canadian Wildlife Service, Edmonton. Unpublished report.

Parks Canada, Calgary. Unpublished report.

Parks Canada, Calgary. Unpublished report.

Parks Canada, Calgary. Unpublished report.

Parks Canada, Calgary. Unpublished report.

Parks Canada, Calgary. Unpublished report.

Parks Canada, Calgary. Unpublished report.

Parks Canada, Calgary. Unpublished report.

Parks Canada, Calgary. Unpublished report.

Waterton Lakes National Park, Parks Canada, Calgary. Unpublished report.

Parks Canada, Calgary; Canadian Wildlife Service, Edmonton. Unpublished report.

Wood Buffalo National Park, Parks Canada, Calgary. Unpublished report.

Parks Canada, Calgary. Unpublished report.

Parks Canada, Calgary. Unpublished report.

Parks Canada, Calgary. Unpublished report.

Canadian Wildlife Service, Edmonton. Unpublished report.

Canadian Wildlife Service, Edmonton. Unpublished report.

Canadian Wildlife Service, Edmonton. Unpublished report.

Canadian Wildlife Service, Edmonton. Unpublished report.

Canadian Wildlife Service, Edmonton. Unpublished report. 


\begin{tabular}{lrl}
\hline \multicolumn{1}{c}{ Author(s) / Editor } & Date & \multicolumn{1}{c}{ Title } \\
\hline Flook, D.R. and McGillis, J.R. & 1969 & $\begin{array}{l}\text { Aerial count of moose, elk and deer, Elk Island National } \\
\text { Park, December 11-13, 1968. }\end{array}$ \\
Fuller, W.A. & 1950 & $\begin{array}{l}\text { Aerial census of northern bison in Wood Buffalo Park and } \\
\text { vicinity. }\end{array}$ \\
Fuller, W.A. & 1951 & $\begin{array}{l}\text { Second aerial census of northern bison, January 20-31, } \\
1951 .\end{array}$ \\
Fuller, W.A. & 1952 & $\begin{array}{l}\text { Aerial buffalo counts, 1952. } \\
\text { Fyten, B. }\end{array}$ \\
Gilbridge, D. & 1990 & $\begin{array}{l}\text { Mountain sheep monitoring - Cairn/Southesk Pass, Jasper } \\
\text { National Park. }\end{array}$ \\
\hline
\end{tabular}

Gilbridge, D.

Green, H.U.

1946 1956

Green, H.U.

Green, H.U.

1956

Hawley, V., Martin, E. and Stewart, D.

1980

Hawley, V., Strobl, R., Bergman, 1982 B. and Noble, J.

Holroyd, G.L. and Gartshore, M.E. 1978

Hunt, B.

Jacobsen, $\mathrm{P}$.

Jacobson, P.

Jacobson, P., Loewan, D. and Holroyd, G.

Jasper National Park.

1968

Jasper National Park.

Karasiuk, D.

Karasiuk, D.J. and McIlveen, D.M. 1977

Keith, R.C.

1974 Caribou-elk ground surveys on low elevation delta-shoreline habitats in Jasper National Park, May 16-19, 1973 .

Kjorlien, M.

1970 Aerial census - moose, elk and deer, Elk Island National Park - January 1970.

Kuyt, E.

1969 Wood bison surveys, Fort Providence area, November 1968 to March 1969.

Kuyt, E.

1970 Reports of wood bison survey, Peace-Athabasca Delta, December 81970 .

Kuyt, E.

1971 Report of wood bison surveys, Fort Providence, April 1, 1971.

Kuyt, E.

1971 Report on fifth bison survey, Peace-Athabasca Delta, March 4, 1971.

Kuyt, E.

1971 Report on fourth bison survey, Peace-Athabasca Delta, February 18, 1971.

Kuyt, E.
Journal / Conference / Etc.

Canadian Wildlife Service, Edmonton. Unpublished report.

Journal of Wildlife Management, 14, 445-451.

Canadian Wildlife Service, Edmonton. Unpublished report.

Canadian Wildlife Service, Edmonton. Unpublished report.

Parks Canada, Calgary. Unpublished report.

Elk Island National Park, Parks Canada, Calgary. Unpublished report.

Elk Island National Park, Parks Canada, Calgary. Unpublished report.

Banff National Park, Parks Canada, Calgary. Unpublished report.

Banff National Park, Parks Canada, Calgary. Unpublished report.

Banff National Park, Parks Canada, Calgary. Unpublished report.

Northwest Territories Fish and Wildlife Service. Yellowknife, NWT. Unpublished report.

Northwest Territories Fish and Wildlife Service. Yellowknife, NWT. Unpublished report.

Prepared for Parks Canada, prepared by Canadian Wildlife Service, Edmonton. Unpublished report.

Parks Canada, Calgary. Unpublished report.

Canada Parks Service report.

Parks Canada, Calgary. Unpublished report.

Banff National Park, Parks Canada, Calgary. Unpublished report.

Parks Canada, Calgary. Unpublished report.

Parks Canada, Calgary. Unpublished report.

Canadian Wildlife Service, Edmonton. Unpublished report.

Canadian Wildlife Service, Edmonton. Unpublished report.

Canadian Wildlife Service, Edmonton. Unpublished report.

Parks Canada, Calgary. Unpublished report.

Canadian Wildlife Service, Edmonton. Unpublished report.

Canadian Wildlife Service, Edmonton. Unpublished report.

Canadian Wildlife Service, Edmonton. Unpublished report.

Canadian Wildlife Service, Edmonton. Unpublished report.

Canadian Wildlife Service, Edmonton. Unpublished report.

Canadian Wildlife Service, Edmonton. Unpublished report. 


\begin{tabular}{|c|c|c|c|}
\hline Author(s) / Editor & Date & Title & Journal / Conference / Etc. \\
\hline Lovass, A.L. & 1961 & Aerial big game surveys, Elk Island National Park, 1961. & $\begin{array}{l}\text { Canadian Wildlife Service, Edmonton. } \\
\text { Unpublished report. }\end{array}$ \\
\hline Love, B.I. & 1944 & $\begin{array}{l}\text { Survey of animals and surroundings, Wood Buffalo Park, } \\
\text { N.W.T., August } 4-27,1944 \text {. }\end{array}$ & Parks Canada, Calgary. Unpublished report. \\
\hline Lukiwski, G.M. & 1982 & Ungulate aerial survey results for Elk Island National Park. & Parks Canada, Calgary. Unpublished report. \\
\hline Lukiwski, G.M. & 1983 & Ungulate aerial survey results for Elk Island National Park. & Parks Canada, Calgary. Unpublished report. \\
\hline McFarlane, G. & 1973 & $\begin{array}{l}\text { Caribou ground survey of Medicine Lake delta, Jasper } \\
\text { National Park, May 16-19, } 1973 \text {. }\end{array}$ & $\begin{array}{l}\text { Canadian Wildlife Service, Edmonton. } \\
\text { Unpublished report. }\end{array}$ \\
\hline
\end{tabular}

McFarlane, G.

1973 Caribou-elk ground survey of Medicine Lake delta, June 5-7,1973.

McGillis, J.R.

1967 Aerial game survey Elk Island National Park, December, 1966 and February 1967.

McGillis, J.R.

1974 Aerial survey, Jasper, Banff and Yoho National Parks, Oct. 30 and $31,1974$.

McGillis, J.R.

1975 Spring helicopter survey of large mammals above 6000 feet in Jasper, Banff and Yoho National Parks.

McGillis, J.R.

1975 Summer helicopter survey of large mammals above 6000 feet in Jasper, Banff and Yoho National Parks.

Novakowski, N.S.

1957 Aerial resurvey of bison in Wood Buffalo National Park and surrounding areas, 1957.

Novakowski, N.S.

1959 Aerial resurvey of the higher density bison areas in Wood Buffalo National Park and the Northwest Territories.

Novakowski, N.S.

1961 Total counts of bison in the higher density areas of Wood Buffalo Park.

Novakowski, N.S.

1963 Total counts of bison in the higher density areas of Wood Buffalo Park.

Oldham, E.G.

1947 Buffalo count Wood Buffalo Park December 1946, January 1947.

Parks Canada Warden Service.

1978 Jasper National Park wildlife aerial census report, 1977-1978.

Peden, D.C.

1977 Report of reconnaissance of the northern Rockies for potential wood bison range, September 22, 1977.

Reynolds, H.W.

1979 Ungulate survey of the Sandhills region of the Suffield Military Reserve, January 16, 17, 1979.

Rippin, B.

Aerial buffalo survey, Fort Smith, N.W.T.

Smith, D.A.

1990

Tonquin Valley caribou monitoring.

Stelfox, J.G.

1968

Stelfox, J.G. and Barlow, R.

Stelfox, J.G., Kloosterman, B. and 1977 Kingsley, M.C.S.

Stelfox, J.G., McGillis, J. and McClain, G.

1974 Helicopter survey - Athabasca and Miette Valleys, March

Stelfox, J.G., Wood, T. and Keith, 1974 R.

Tempany, I.R. and Cooper, S.

Tempany, I.R. and Cooper, S.

Tempany, I.R. and Cooper, S.

1975 12,1974 .

Bighorn sheep productivity helicopter census, Aug. 10, 1968.

Caribou helicopter survey, Maligne mountains (Skyline Trail) Jasper National Park, July 15, 1974.

Wildlife census and survey project in national parks of western Canada.

Helicopter survey of caribou-elk and other wild ungulates. Maligne mountains and Athabasca Valley, Jasper.

Bison surveys in the higher density areas of Wood Buffalo National Park.

Total bison count on secondary ranges, Wood Buffalo National Park, February 1975.

Total bison count, Wood Buffalo National Park, February 1975.
Canadian Wildlife Service, Edmonton. Unpublished report.

Canadian Wildlife Service, Edmonton. Unpublished report.

Canadian Wildlife Service, Edmonton. Unpublished report.

Canadian Wildlife Service, Edmonton. Unpublished report.

Canadian Wildlife Service, Edmonton. Unpublished report.

Canadian Wildlife Service, Edmonton. Unpublished report.

Canadian Wildlife Service, Edmonton. Unpublished report.

Canadian Wildlife Service, Edmonton. Unpublished report.

Canadian Wildlife Service, Edmonton. Unpublished report.

Forest and Wildlife, Northwest Territories. Unpublished report.

Parks Canada, Calgary. Unpublished report.

Canadian Wildlife Service, Edmonton. Unpublished report.

Canadian Wildlife Service, Edmonton. Unpublished report.

Game Management Division, Government of N.W.T. Yellowknife, NWT. Unpublished report.

Parks Canada, Calgary. Unpublished report.

Waterton Lakes National Park. Canadian Wildlife Service, Edmonton. Unpublished report.

Canadian Wildlife Service, Edmonton. Unpublished report.

Canadian Wildlife Service, Edmonton. Unpublished report.

Canadian Wildlife Service, Edmonton. Unpublished report.

Canadian Wildlife Service, Edmonton. Unpublished report.

Canadian Wildlife Service, Edmonton. Unpublished report.

Parks Canada, Calgary and Canadian Wildlife Service, Edmonton. Unpublished report.

Parks Canada, Calgary and Canadian Wildlife Service, Edmonton. Unpublished report. 
Federal Ungulate Surveys

\begin{tabular}{lcll}
\hline \multicolumn{1}{c}{ Author(s) / Editor } & Date & \multicolumn{1}{c}{ Title } & Journal / Conference / Etc. \\
\hline Tempany, I.R. and Cooper, S. & 1976 & $\begin{array}{l}\text { Total bison count, Wood Buffalo National Park, February } \\
1976 .\end{array}$ & $\begin{array}{l}\text { Parks Canada, Calgary and Canadian Wildlife } \\
\text { Service, Edmonton. Unpublished report. }\end{array}$ \\
$\begin{array}{llll}\text { Thordarson, W.G. } \\
\text { Watt, R. }\end{array}$ & 1976 & $\begin{array}{l}\text { Wildlife census, Jasper National Park, 1976. } \\
\text { Wildlife survey - March 26, 1983. Waterton Lakes }\end{array}$ & $\begin{array}{l}\text { Canadian Wildlife Service, Edmonton. } \\
\text { Unpublished report. }\end{array}$ \\
$\begin{array}{llll}\text { Westworth, D. } \\
\text { National Park. }\end{array}$ & $\begin{array}{l}\text { Report on caribou-elk ground surveys in Jasper National } \\
\text { Park, May-August 1972. }\end{array}$ & $\begin{array}{l}\text { Canadian Wildlife Service, Edmonton. } \\
\text { Unpublished report. }\end{array}$ \\
Williams, R.W. & 1983 & $\begin{array}{l}\text { Northwest Territories Game Management } \\
\text { Division, Yellowknife, NWT. Unpublished } \\
\text { report. }\end{array}$
\end{tabular}




\begin{tabular}{lcl}
\hline \multicolumn{1}{c}{ Author(s) / Editor } & Date & \multicolumn{1}{c}{ Title } \\
\hline Anderson, P. and Donnelly, M. & 1982 & The Birch Hills browse production and utilization study. \\
Barrett, M.W. & 1972 & $\begin{array}{l}\text { A review of the diet, condition, diseases, and parasites of } \\
\text { the Cypress Hills moose. }\end{array}$ \\
Barrett, M.W. & 1974 & $\begin{array}{l}\text { Importance, utilization and quality of Artemisia cana on } \\
\text { pronghorn winter ranges in Alberta. }\end{array}$ \\
Bichlmaier, M. & 1985 & $\begin{array}{l}\text { Response of understory vegetation of some boreal } \\
\text { mixedwood forest communities to native ungulate } \\
\text { foraging. }\end{array}$
\end{tabular}

Bishoff, K.W.

1981 Yield, use and chemical composition of forage in Elk Island National Park, Alberta.

Blood, D.A.

1962 Vegetation analysis of big game exclosure plots, Elk Island National Park, 1960 and 1961.

Blyth, C.B.

1980 Vegetation management plan, Elk Island National Park.

Bohmer, C.R. and Lynch, G.M. 1976 Big game browse condition and utilization in the Edson region: 1975 survey.

Bouckhout, L.W.

1971 Assessment of browsing conditions in Elk Island National Park, Alberta.

Brusnyk, L.M. and Westworth, D.A.

1983 An investigation of browse production and utilization in Shiningbank study area.

Cairns, A.L.

1976

Chappel, R.W. and Hudson, R.J. 1981

Clark, J. and Vriend, $\mathrm{H}$.

1981

Cool, N.L.

Cowan, I.McT.

(in Assessment of winter nutrition of moose and wapiti

prep.) through chemical analysis of feces and urine in snow.

1950 Investigations of food values of woody plants in moose

Cowan, I. McT., Hoar, W.S. and 1950 Hatter, J.

Dickinson, D.M.

1969

Dickinson, D.M.

1969

Duffy, R.G.

Fargey, P.

Fargey, P. and Hawley, A.W.L.

1986

Fargey, P.J.

1988

Fargey, P.T. and Hawley, A.W.L. 1989

Festa-Bianchet, $\mathbf{M}$.

1988

Festa-Bianchet, M., and Geist, V. 1990

Flook, D.R. browse; summary report.

The effect of forest succession upon the quality and upon the nutritive values of woody plants used as food by moose.

Distribution and food habits of moose, wapiti, deer, bison and snowshoe hare in Elk Island National Park, Alberta.

Digestive function of growing wapiti.

1981 southern region deer browse survey.

Cooperative forage resources study plan - phase two.

Forage resources and utilization in the Cypress Hills Provincial Park.

An ecological study of vegetation change in the northern Porcupine Hills, Alberta.

Wapiti selection of grasses and legumes.

Wapiti selection of forage species potentially used in reclamation.

Seasonal pattems of forage selection by wapiti (Cervus elaphus L.) in relation to land reclamation.

Seasonal patterns of forage selection by wapiti (Cervus elaphus) in relation to land reclamation.

Seasonal range selection in bighorn sheep: conflicts between forage quality, forage quality, and predator avoidance.

Forage characteristics and bighom sheep phenotype.

Analyses of range exclosure plots, Bow Valley, Banff Park, 1958.
Journal / Conference / Etc.

Alberta Fish and Wildlife Division, Edmonton. Unpublished report.

Alberta Fish and Wildlife Division, Edmonton. Unpublished report.

pp. 337-359. In: Proceedings of 6th Biennial Antelope States Workshop. Salt Lake City, UT

M.Sc. Thesis. University of Alberta, Edmonton.

M.Sc. Thesis. University of Alberta, Edmonton.

Canadian Wildlife Service, Edmonton.

Unpublished report.

Parks Canada, Calgary. Unpublished report.

Alberta Fish and Wildlife Division, Edmonton. Unpublished report.

Canadian Wildlife Service, Edmonton. Unpublished report.

Prepared by Westworth and Associates Ltd., prepared for Alberta Fish and Wildlife Division, Edmonton. Unpublished report.

M.Sc. Thesis. University of Calgary, Calgary.

Joumal of Wildlife Management, 45, 148-155.

Alberta Fish and Wildlife Division, Edmonton. Unpublished report.

M.Sc. Thesis. University of Alberta, Edmonton.

Canadian Wildlife Service, Edmonton.

Unpublished report.

Canadian Journal of Research, 28, 249-271.

Alberta Fish and Wildlife Division, Edmonton. Unpublished report.

Alberta Fish and Wildlife Division, Edmonton. Unpublished report.

M.Sc. Thesis. University of Calgary, Calgary.

pp. 24-26. In: Proceedings of 3rd Annual Alberta Game Growers' Association Conference. Renecker, L.A. (ed.). Red Deer, Oct. 23-24, 1987.

pp. 93-109. Proceedings of Canadian Land Reclamation Association Conference. Powter, C..B., Fesseden, R.J. and Walker, D.G. (compilers). Hinton, Sept. 25-26, 1986.

M.Sc. Thesis. University of Alberta, Edmonton.

Alberta Environmental Centre, Vegreville, Alberta. AECV89-R3, 112 pp.

Oecologia, 75, 580-586.

Journal of Mammalogy, 71, 697-699.

Canadian Wildlife Service, Edmonton. Unpublished report. 


\begin{tabular}{|c|c|c|}
\hline Author(s) / Editor & Date & Title \\
\hline Flook, D.R. & 1960 & $\begin{array}{l}\text { Establishment and analyses of permanent range transects } \\
\text { Ya Ha Tinda Ranch, July 16-19, } 1959 .\end{array}$ \\
\hline Gates, C.C. and Hudson, R.J. & 1983 & Foraging behaviour of wapiti in a boreal forest enclosur \\
\hline Green, H.U. & 1956 & Annual elk range report to chief warden. \\
\hline Gudmundson, L. & 1984 & $\begin{array}{l}\text { Preliminary browse utilization and plant condition } \\
\text { investigations on deer range in Canadian Forces Base } \\
\text { Suffield. }\end{array}$ \\
\hline
\end{tabular}

Gudmundson, L.

1985 A preliminary study of browse utilization and deer food habits on the McIntyre Ranch.

Hall, B., Treichel, B. and Dube, L. 1974 Ya-Ha-Tinda elk rumen analysis.

Hawley, A.W.L., Peden, D.G., Reynolds, H.W. and Stricklin,

W.R.

Holsworth, W.N.

Hudson, R.J. and Frank, S.

Hudson, R.J. and Nietfeld, M.T. 1985

Hudson, R.J. and Watkins, G.W. 1986

IEC Beak Consultants Ltd.

IEC Beak Consultants Ltd.

1986

Johnston, A., Berzeau, L.M. and Smoliak, S.

Kelsall, J.P.

Kjorlien, M.

Madsen, D.

McCrory, W.

McCrory, W.

1967 Absorption and excretion by mountain goats of minerals found in a natural lick.

McCrory, W.P.

1969 Final report on study of natural licks used by mountain goats and bighom sheep in Jasper National Park.

McGillis, J.R.

1968 Appraisal of grazing intensity in Elk Island National Park winter 1966-67.

Milnet, B.J.

1977 Vegetation analysis of ungulate range exclosures, Elk Island National Park.

Mitchell, G.J. and Cormack,

R.G.H.

1960 An evaluation of big game winter range in southwestem Alberta.

Mitchell, G.J. and Smoliak, S.

Moller, K.

1977 Big game browse survey in WMU M-522 and WMU F-358, 1977.

Moller, $\mathbf{K}$.

1978 Big game browse survey in the Peace River region, spring 1978.

Moller, K.

1979 Big game browse survey in the Peace River region, spring 1979.
Journal / Conference / Etc.

Canadian Wildlife Service, Edmonton. Unpublished report.

Naturaliste Canadien, 110, 197-208.

Banff National Park, Parks Canada, Calgary. Unpublished report.

Alberta Fish and Wildlife Division, Edmonton. Unpublished report.

Alberta Fish and Wildlife Division, Edmonton. Unpublished report.

Alberta Fish and Wildlife Division, Edmonton. Unpublished report.

Journal of Range Management, 34, 126-130.

Canadian Wildlife Service, Edmonton.

Unpublished report.

Journal of Range Management, 40, 71-75.

Journal of Range Management, 38, 80-82.

Canadian Journal of Zoology, 64, 1705-1708.

Prepared for Alberta Fish and Wildlife Division, Calgary. Prepared by IEC Beak Consultants Ltd. Calgary, Alberta. Unpublished report.

Prepared for Alberta Fish and Wildlife Division, Calgary. Prepared by IEC Beak Consultants Lid., Calgary, Alberta. Unpublished report.

Joumal of Wildlife Management, 32, 773-777.

Canadian Journal of Zoology, 48, 605.

Parks Canada, Calgary. Unpublished report.

Parks Canada, Calgary. Unpublished report.

Canadian Wildlife Service, Edmonton. Unpublished report.

Canadian Wildlife Service, Edmonton. Unpublished report.

Canadian Wildlife Service, Edmonton. Unpublished report.

Canadian Wildlife Service, Edmonton. Unpublished report.

Canadian Wildlife Service, Edmonton. Unpublished report.

Journal of Range Management, 13, 235-239.

Journal of Wildlife Management, 35, 238-250.

Alberta Fish and Wildlife Division, Edmonton. Unpublished report.

Alberta Fish and Wildlife Division, Edmonton. Unpublished report.

Alberta Fish and Wildlife Division, Edmonton. Unpublished report. 


\begin{tabular}{ccc}
\hline Author(s) / Editor & Date & Title \\
\hline Morgantini, L.E. & 1985 & The assessment of three elk winter ranges in Alberta: an
\end{tabular}
appraisal.

Morgantini, L.E.

1987

Elk winter food habits and forage quality along the eastern slopes of Alberta: a review.

Morgantini, L.E. and Hudson, R.J. 1983

Morgantini, L.E. and Hudson, R.J. 1985

Morgantini, L.E. and Hudson, R.J. 1986

Nietfeld, M.T.

1983

Nietfeld, M.T. and Hudson, R.J.

1985

Nowlin, R.A.

1976

Olgilvie, L.M.

Olson, W., and Blyth, C.B.

Olson, W., and Blyth, C.B.

Olson, W. and Westhauer, A.L.

1988

Polster, A.H

1981

Renecker, L.A.

Renecker, L.A. and Hudson, R.J. 1985

Renecker, L.A. and Hudson, R.J. 1986

Renecker, L.A. and Hudson. R.J. 1988

Renecker, L.A., Hudson, R.J. and 1982

Berzins, $\mathbf{R}$.

Retfalvi, L.

Reynolds, H.W.

Reynolds, H.W.

Reynolds, H.W.

Reynolds, H.W., Hansen, R.M. and Peden, D.G.

Rhude, P. and Hall, W.K.

Richmond, R.J., Hudson, R.J. and 1977 Christopherson, R.J.

Ridgeway, P.

1973
Nutritional significance of altitudinal migrations in wapiti.

Changes in diets of wapiti during a hunting season.

Nutritional significance of altitudinal migration in wapiti.

Foraging behaviour of wapiti in the boreal mixed-wood forest, central Alberta.

Foraging ecology of wapiti in the boreal mixed-wood forest, central Alberta.

Relationships between habitats, forages and carrying capacity of moose range in northern Alberta. Part 1: moose preferences for habitat strata and forages at Ministik Lake, Alberta.

An ecological study of forest types in the Porcupine Hills, Alberta, with special reference to understory vegetation productivity.

1984 browse study and herd recommendation report.

Elk Island National Park, browse study and herd recommendation report.

Elk Island National Park ungulate and vegetation management: Status and Recommendations.

Yield and utilization of woody browse by ungulates in Elk Island National Park, 1978-79 and 1980-81.

Digestive efficiency of wapiti with variation in diet: a comparative approach.

Estimation of dry matter intake of free-ranging moose.

Seasonal foraging rates of free-ranging moose.

Seasonal quality of forages used by moose in the aspen boreal forest, central Alberta.

Nylon bag digestibility and rate of passage of digesta in moose, wapiti and cattle.

Vegetation analysis of ungulate exclosures at Elk Island National Park, 1967.

Bison dietary analysis from fecal sample examination.

The food and food habits of Bison bison in the Mackenzie District, N.W.T.

Bison diets of Slave River Lowlands, Canada.

Diets of the Slave River lowland bison herd, Northwest Territories, Canada.

Food habits of white-tailed deer and mule deer in Camp Wainwright, Alberta.

Comparison of forage intake and digestibility by American bison, yak and cattle.

Rumen analysis of bighorn sheep from Ram Mountain, 1969-72.
Journal / Conference / Etc.

pp. 106-116. In: 1984 Western States and Provinces Elk Workshop. Nelson, R.W. (ed) Edmonton. April 17-19, 1984.

pp. 75-92. In: Proceedings of the 1985 and 1986 Alberta Reclamation Conferences. Alberta Chapter, Canadian Land Reclamation Association. AC/CLRA report \#71-1.

Agricultural and Forestry Bulletin Special Issue, $62,109-112$.

Journal of Range Management, 38, 77-79.

Arctic and Alpine Research, (in review).

M.Sc. Thesis. University of Alberta, Edmonton.

pp. 131. In: Proceedings of 1984 Western States and Provinces Elk Workshop. Nelson, R.W. (ed.). Edmonton, April 17-19, 1984.

Alberta Fish and Wildlife Division, Edmonton. Unpublished report.

M.Sc. Thesis. University of Calgary, Calgary.

Elk Island National Park, Parks Canada, Calgary. Unpublished report.

Elk Island National Park, Parks Canada, Calgary. Unpublished report.

Parks Canada, Calgary. Unpublished report.

Parks Canada, Calgary. Unpublished report.

pp. 132. In: Proceedings of 1984 Western States and Provinces Elk Workshop. Nelson, R.W. (ed.). Edmonton, April 17-19,1984.

Journal of Wildlife Management, 49, 785-792.

Journal of Wildlife Management, 50, 143-147.

Holarctic Ecology, 11, 111-118.

Alces, 18, 1-16.

Canadian Wildlife Service, Edmonton. Unpublished report.

Canadian Wildlife Service, Edmonton. Unpublished report.

Canadian Wildlife Service, Edmonton. Unpublished report.

Canadian Wildlife Service, Edmonton. Unpublished report.

Journal of Wildlife Management, 42, 581-590.

Alberta Fish and Wildlife Division, Edmonton Unpublished report.

Acta Theriologica, 22, 225-230.

Alberta Fish and Wildlife Division, Edmonton. Unpublished report. 


Author(s) / Editor Date Title Journal / Conference / Etc.

Risenhoover, K.L., Renecker, L.A. 1985 Effects of secondary metabolites from balsam poplar and and Morgantini, L.E.

Russell, L.J.

1988 Preliminary results of Castle-Carbondale elk range study.

Schoeder, K. and Blyth, C.

Shank, C.C.

1982 Age-sex differences in the diets of wintering Rocky Mountain sheep.

Stelfox, J.G.

1974 Browse production and utilization during 17 years of regeneration in a white spruce forest.

Stelfox, J.G.

1980 Nutritive value and preference rating of common game browse plants in Alberta.

Stelfox, J.G. and McGillis, J.R. 1976 Vegetation production in grazed mixed prairie ranges, Suffield Military Reserve, October 3-6, 1976.1.

Vegetation production and utilization: grazed and ungrazed ranges, 1975 and 1976.

Stelfox, J.G. and Tilson, D.

1985 Elk-livestock-range interactions in the Waterton Biosphere Reserve, 1984-1985.

Sullivan, J.P. and Stelfox, J.G.

1974 Wildlife food habits and seasonal ranges in Jasper Townsite area, summer 1974.

Sullivan, J.P. and Stelfox, J.G.

1976 Big game range exclosures in the national parks of western Canada.

Telfer, E.S.

1969 Twig weight-diameter relationships for browse species.

Telfer, E.S.

1972 A reconnaissance of the moose range in the Peace-Athabasca Delta.

Telfer, E.S.

1972 Range trend studies at Elk Island National Park - a project plan.

Telfer, E.S.

1972 Report on the establishment of range trend transects at Elk Island National Park.

Telfer, E.S.

1972 Weight tables of twigs of various diameters at Elk Island National Park.

Telfer, E.S.

1974 A trend survey method for browse ranges using the Shafer twig count techniques.

Telfer, E.S.

1974 Browse yield and use by ungulates in Elk Island National Park, 1973-74.

Telfer, E.S.

1974 Vertical distribution of cervid and snowshoe hare browsing.

Telfer, E.S.

1976 Yield and utilization of woody browse by ungulates in Elk Island National Park. 1975-1976

Telfer, E.S.

1981 Browse inventories: techniques and evaluation.

Telfer, E.S.

Browse yield and utilization distribution on the Streeter Basin experimental watershed of southern Alberta.

Telfer, E.S. and Caims, A.

Stem breakage by moose.

Treichel, B.

Cypress Hills elk and moose rumen analysis 1978.

Treichel, B. and Dube, L.

Wainwright deer rumen analysis 1980 .

Treichel, B. and Hall, B.

Ya-Ha-Tinda elk rumen analysis.

Trottier, G.C.

1976 Big game range exclosures in the national parks of western Canada.
Journal of Range Management, 38, 370-372.

Alberta Fish and Wildlife Division, Edmonton. Unpublished report.

Elk Island National Park, Parks Canada, Calgary. Unpublished report.

Ecology, 63, 627-633.

Canadian Wildlife Service, Edmonton. Unpublished report.

Canadian Wildlife Service, Edmonton. Unpublished report.

Canadian Wildlife Service, Edmonton. Unpublished report.

Prepared for Parks Canada, Calgary. Prepared by Canadian Wildlife Service, Edmonton. Unpublished report.

Canadian Wildlife Service, Edmonton. Unpublished report.

Canadian Wildlife Service, Edmonton. Unpublished report.

Journal of Wildlife Management, 34, 917-921.

Canadian Wildlife Service, Edmonton. Unpublished report.

Canadian Wildlife Service, Edmonton. Unpublished report.

Canadian Wildlife Service, Edmonton. Unpublished report.

Canadian Wildlife Service, Edmonton. Unpublished report.

Proceedings of North American Moose Conference and Workshop, 10, 160-171.

Canadian Wildlife Service, Edmonton. Unpublished report.

Joumal of Wildlife Management, 38, 944-946.

Canadian Wildlife Service, Edmonton. Unpublished report.

pp. 67-82. In: Symposium on Census and Inventory Methods for Population and Habitats. Miller, F.L. and Gunn, A. (eds.). Banff, April $10,1980$.

Canadian Wildlife Service, Edmonton. Unpublished report.

Joumal of Wildlife Management, 42, 639-642.

Alberta Fish and Wildlife Division, Edmonton. Unpublished report.

Alberta Fish and Wildlife Division, Edmonton. Unpublished report.

Alberta Fish and Wildlife Division, Edmonton. Unpublished report.

Prepared for Parks Canada, Calgary; prepared by Canadian Wildlife Service, Edmonton. Unpublished report. 


\begin{tabular}{|c|c|c|c|}
\hline Author(s) / Editor & Date & Title & Journal / Conference / Etc. \\
\hline Trottier, G.C. & 1976 & $\begin{array}{l}\text { Range reconnaissance, Willow Creek and vicinity, Jasper } \\
\text { National Park, } 1975 \text {. }\end{array}$ & $\begin{array}{l}\text { Canadian Wildlife Service, Edmonton. } \\
\text { Unpublished report. }\end{array}$ \\
\hline Trottier, G.C. & 1979 & Analysis of range enclosures, Jasper National Park 1978. & $\begin{array}{l}\text { Canadian Wildlife Service, Edmonton. } \\
\text { Unpublished report. }\end{array}$ \\
\hline Trottier, G.C. & 1981 & $\begin{array}{l}\text { Beaked hazelnut - a key browse species for moose in the } \\
\text { boreal forest region of western Canada. }\end{array}$ & Alces, $17,257-281$. \\
\hline Trottier, G.C. & 1982 & Range exclosures in the western region National Parks. & Alberta Naturalist, 12, 12-14. \\
\hline Trottier, G.C. and Fehr, A. & 1982 & $\begin{array}{l}\text { Re-evaluation of four range exclosures in ,Banff National } \\
\text { Park, } 1981 \text {. }\end{array}$ & $\begin{array}{l}\text { Canadian Wildlife Service, Edmonton. } \\
\text { Unpublished report. }\end{array}$ \\
\hline Van Camp, J. & 1975 & $\begin{array}{l}\text { Snow conditions and the winter feeding behavior of Bison } \\
\text { bison in Elk Island National Park. }\end{array}$ & $\begin{array}{l}\text { Canadian Wildlife Service, Edmonton. } \\
\text { Unpublished report. }\end{array}$ \\
\hline Van Camp, J. and Telfer, E.S. & 1975 & $\begin{array}{l}\text { Browse yield and use by ungulates in Elk Island National } \\
\text { Park, 1973-74. }\end{array}$ & $\begin{array}{l}\text { Canadian Wildlife Service, Edmonton, and Parks } \\
\text { Canada, Calgary. Unpublished report. }\end{array}$ \\
\hline $\begin{array}{l}\text { Van Tighem, K., Trottier, G.C. and } \\
\text { Hutchinson, R.C. }\end{array}$ & 1985 & Grazing capacity study, Jasper National Park. & $\begin{array}{l}\text { Canadian Wildlife Service, Edmonton. } \\
\text { Unpublished report. }\end{array}$ \\
\hline Walker, D. and Weijer, J. & 1974 & $\begin{array}{l}\text { The collection and maintenance of native grasses of the } \\
\text { eastern slopes of the Rocky Mountains. }\end{array}$ & $\begin{array}{l}\text { Alberta Fish and Wildlife Division, Edmonton. } \\
\text { Unpublished report. }\end{array}$ \\
\hline Westra, R. & 1978 & $\begin{array}{l}\text { The effect of temperature and season on digestion and urea } \\
\text { kinetics in growing wapiti. }\end{array}$ & Ph.D. Thesis. University of Alberta, Edmonton. \\
\hline Westra, R. and Hudson, R.J. & 1979 & Urea recycling in wapiti. & $\begin{array}{l}\text { pp. 236-239. In: North American elk: ecology, } \\
\text { behavior and management. Boyce, M.S. and } \\
\text { Hayden-Wing, L.D. (eds.). University of } \\
\text { Wyoming Press, Laramie, WY. }\end{array}$ \\
\hline Westra, R. and Hudson, R.J. & 1981 & Digestive function of wapiti calves. & Journal of Wildlife Management, 45, 148-155. \\
\hline $\begin{array}{l}\text { Westworth, D.A., Ewaschuk, E. } \\
\text { and Brusnyk, L. }\end{array}$ & 1983 & $\begin{array}{l}\text { An investigation of browse and forage production in the } \\
\text { Rochester-Boyle study area. }\end{array}$ & $\begin{array}{l}\text { Prepared for Alberta Fish and Wildlife Division, } \\
\text { prepared by West worth, D.A. and Associates } \\
\text { Lid., Edmonton. Unpublished report. }\end{array}$ \\
\hline $\begin{array}{l}\text { Young, B.A., Schaefer, A. and } \\
\text { Chimwano, A. }\end{array}$ & 1977 & Digestive capabilities of cattle, bison and yak. & $\begin{array}{l}\text { pp. 31-34. In: } 56 \text { Annual Feeders' Day Report. } \\
\text { Department of Animal Science, University of } \\
\text { Alberta, Edmonton. }\end{array}$ \\
\hline
\end{tabular}




\begin{tabular}{|c|c|c|}
\hline Author(s) / Editor & Date & Title \\
\hline Ad Hoc Committee, & 1976 & $\begin{array}{l}\text { Potential for meat production from the marginal land } \\
\text { resources of Alberta. Vols. } 1 \text { and } 2 \text {. }\end{array}$ \\
\hline Adams, $\mathrm{S}$. & 1985 & The game ranching controversy. \\
\hline Alsager, D.E. & 1982 & $\begin{array}{l}\text { Canadian deer farming and its potential as a viable } \\
\text { agricultural industry in northern hemisphere countries of } \\
\text { the world. }\end{array}$ \\
\hline Alsager, D.E. and Alsager E.L. & 1984 & $\begin{array}{l}\text { Canadian deer farming and its potential as a viable } \\
\text { agricultural industry. }\end{array}$ \\
\hline Anonymous. & 1985 & $\begin{array}{l}\text { Taking the wild out of wildlife - F.A.N. position paper on } \\
\text { game ranching in Alberta. }\end{array}$ \\
\hline Anonymous. & 1987 & Procedures manual for big game farmers. \\
\hline $\begin{array}{l}\text { Christopherson, R.J. and Hudson, } \\
\text { R.J. }\end{array}$ & 1978 & Northern animal agriculture. \\
\hline Delver, J.L. & 1988 & Disease inspection. \\
\hline
\end{tabular}

Journal / Conference / Etc.

Department of Animal Science, Faculty of Agriculture and Forestry, University of Alberta, Edmonton.

Environmental Views, 8, 6-7.

Third International Theriological Congress. University of Helsinki, Helsinki, Finland.

Acta Zoologica Fennica, 172, 231-232.

Alberta Naturalist, 15, 113-116.

Alberta Fish and Wildlife Division Edmonton. Published report.

University of Alberta Agriculture and Forestry Bulletin, 1, 3-5.

pp. 83-84. In: Proceedings of the 3rd Annual Alberta Game Growers' Association Conference. Renecker, L.A. (ed.). Red Deer, October 23-24, 1987.

Geist, V.

Geist, V.

Geist, V.

Geist, V,

Geist, V.

Ghostkeeper, E.

Game ranching.

Some problems associated with game ranching.

Game ranching: threat to wildlife conservation in North America.

How markets in wildlife meat and parts, and the sale of hunting privileges, jeopardize wildlife conservation.

Deer ranching for products and paid hunting: threat to conservation and biodiversity by luxury markets.

Mixed-species game ranching on metis settlements.

Godkin, G.

Meat inspection and production for farm-raised game.

Haigh, J.C.

Reproductive management of farmed wapiti.

Hawley, A. and Peden, D.G.

Canada's buffalo renaissance.

Hawley, A.W.L.

1985

Commercial meat production from wild cervids.

Hawley, A.W.L.

1989

Bison farming.

Hawrysh, Z.

1988

Carcass composition and need for meat quality.

Hudson, R.J.

1976

Potential for meat production from marginal land resources. Vol. 1 Final report.

Hudson, R.J.

1981
Agricultural potential of the wapiti.
Western Canada Outdoors, 7, 10.

Western Canada Outdoors, 7, 1.

Wildlife Society Bulletin, 13, 594-598.

Conservation Biology, 2, 15-16.

Special presentation, Proceedings of the Biology of Deer Symposium, Mississippi, Mississippi State University, May 28, 1990.

pp. 13-17. In: Proceedings of 1984 Western States and Provinces Elk Workshop. Nelson, R.W. (ed.). Edmonton, April 17-18, 1984.

pp. 49-50. In: Proceedings of 3rd Annual Alberta Game Growers' Association Conference. Renecker, L.A. (ed.). Red Deer, October 23-24, 1987.

pp. 107-110. In: Proceedings of 3rd Annual Alberta Game Growers' Association Conference. Renecker, L.A. (ed.). Red Deer, October 23-24, 1987.

Canadian Geography, Oct./Nov., 32-37.

pp. 327-337. In: Biology of deer production. Fennessy, P.F. and Drew, K.R. (eds.). Royal Society of New Zealand Bulletin No. 22.

In: Wildlife production systems: economic utilization of wild ungulates. Hudson, R.J., Drew, K.R. and Baskin, L.M. (eds.) Cambridge University Press, Cambridge, UK.

pp. 55-58. In: Proceedings of the 3rd Annual Alberta Game Growers' Association Conference Renecker, L.A. (ed.). Red Deer, Oct. 23-24, 1987.

Ad Hoc Committee. Faculty of Agriculture and Forestry, University of Alberta, Edmonton.

pp. 80-86. In: 60th Annual Feeders' Day Report. Department of Animal Science, University of Alberta, Edmonton. 


\begin{tabular}{ccc}
\hline Author(s) / Editor & Date & Title \\
\hline Hudson, R.J. & 1983 & Commercial wildlife production in westem Canada.
\end{tabular}

Hudson, R.J.

1984

1985

The potential of wild ruminants.

Hudson, R.J.

1988

Hudson, R.J.

Hudson, R.J., Drew, K.R. and Baskin, L.M. (eds.)

Kowalchuk, C.L.

Kozak, H.

Lynch, G.

Lynch, G.

MacLean, S.

Matthews, L.C.

Nichols, J.R.

Novakowski, N.S. and Solman, V.E.F.

Patten, D.

Reisenburger, $\mathbf{R}$.

1988

Renecker, L.A.

Renecker, L.A.

1988

Velvet production and the market goal.

Renecker, L.A.

1990

Game farming; agricultural diversity.

Renecker, L.A.

1990

Game farming in Canada: a business?.

1991

Wildlife production systems: economic utilization of wild ungulates.

Ranching with wapiti and moose in Alberta?

Dystocia in farmed wapiti.

The biological potential for game ranching at Paddle Prairie and Kikino-Casslan Metis settlements.

Status of big game farm regulations in Alberta.

Procedures recommended for the removal of velvet antlers from wapiti.

A bioeconomic analysis of the potential for game ranching in northern Alberta.

Elk ranching - legislative controls and enforcement.

Potential of wildlife as a protein source.

The Adam Ranch: management and marketing program for bison.

Role of Alberta government in a new industry.

Game production developments in Canada and Alberta.

Renecker, L.A.
Journal / Conference / Etc.

pp. 134-148. In: Symposium on Fish and Wildlife Resources and Economic Development. Sponsored by the Alberta Society of Professional Biologists and Alberta Fish and Wildlife Division, Edmonton, April 26-27, 1983.

Agrologist, 13, 14-15.

pp. 10-12. In: Proceedings of the 1984 Western States and Provinces Elk Workshop. Nelson, R.W. (ed.). Edmonton, April 17-18, 1984.

pp. 1-4. In: Proceedings of the 3rd Annual Alberta Game Growers' Association Conference. Renecker, L.A. (ed.). Red Deer, Oct. 23-24, 1987.

Cambridge University Press, Cambridge, UK.

Rangelands, 6, 7-9.

pp. 21-23. In: Proceedings of the 3rd Annual Alberta Game Growers' Association Conference. Renecker, L.A. (ed.). Red Deer, Oct. 23-24, 1987.

Alberta Fish and Wildlife Division Proposal, Edmonton. Unpublished report.

pp. 9-15. In: Proceedings of the 3rd Annual Alberta Game Growers' Association Conference. Renecker, L.A. (ed.). Red Deer, Oct. 23-24, 1987.

pp. 62-67. In: Proceedings of the 3rd Annual Alberta Game Growers' Association Conference. Renecker, L.A. (ed.). Red Deer, Oct. 23-24, 1987.

M.Sc. Thesis. University of Alberta, Edmonton.

pp. 18-23. Proceedings of the 1984 Western States and Provinces Elk Workshop. Nelson, R.W. (ed.). Edmonton, April 17-18, 1984.

Journal of Animal Science, 40, 1016-1019.

pp. 29-32. In: Proceedings of the 3rd Annual Alberta Game Growers' Association Conference Renecker, L.A. (ed.). Red Deer, Oct. 23-24, 1987.

pp. 16. In: Proceedings of the 3rd Annual Alberta Game Growers' Association Conference Renecker, L.A. (ed.). Red Deer, Oct. 23-24, 1987.

pp. 5-8. In: Proceedings of the 3rd Annual Alberta Game Growers' Association Conference. Renecker, L.A. (ed.). Red Deer, Oct. 23-24, 1987.

pp. 59-61. In: Proceedings of the 3rd Annual Alberta Game Growers' Association Conference. Renecker, L.A. (ed.). Red Deer, Oct. 23-24, 1987.

In: Proceedings of 4th Annual National Indian Agricultural Symposium. Spokane, Washington

Canadian Game Farmer and Bison Journal, June, 15-17.

In: Conservation and sustainable development. Renecker, L.A. and Hudson, R.J. (eds.). Univ. of Alaska, Fairbanks 


\begin{tabular}{ccc}
\hline Author(s) / Editor & Date & Title \\
\hline Renecker, L.A. and Blewald, S. & 1985 & $\begin{array}{l}\text { A management, production and marketing plan for the } \\
\text { Kikino Wildlife Ranch. }\end{array}$
\end{tabular}

Renecker, L.A. and Kozak, H.A.

1987

Renecker, L.A. and Kozak, H.A.

1987

Renecker, L.A. and Valcez, R.

1991

Renecker, L.A., and Valdez, R.

Renecker, L.A., Blyth, C.B. and Gates, C.C.

Renecker, L.A. (ed.)

1987

Renecker, L.A., Hudson, R.J. and 1984 Lynch, G.W.

Renecker, L.A., Hudson, R.J. and 1984 Lynch, G.W.

Richmond, R.J., Telfer, E.S. and Hudson, R.J.

Samson, K.

Scotter, G.W. and Telfer, E.S.

Telfer, E.S.

Telfer, E.S. and Scotter, G.W.

Tennessen, $\mathbf{T}$.

1978

Tennessen, T. and Hudson, R.J. 1981
Feasibility assessment of game ranching on the Cold Lake game farm: a setting in the mixed-wood forest zone, north-eastern Alberta.

Game ranching in western Canada.

Commercial game production in North America.

History of the International Wildlife Ranching Symposium.

Game ranching in westem Canada.

Focus on a new industry

Meat production from moose in western Canada.

Moose husbandry in Alberta, Canada.

Intensive wildlife production. An alternative management system for Indian and Inuit lands.

The application of modern genetics to game ranching.

Potential for red meat production from wildlife in boreal and arctic regions.

Alternatives in aspen forest management involving red meat production.

Potential for game ranching in boreal aspen forests of western Canada.

Behavioural characteristics of ungulates relevant to domestication.

Traits relevant to the domestication of herbivores.
Journal / Conference / Etc.

Canada Employment and Immigration. Phase 1 LE.A.D. Planning Project for the Kikino Wildlife Ranching Association, St. Paul.

Consulting report to Canada/Alberta Northern Development Agreement, Peace River and Alberta Recreation, Parks and Wildlife Foundation, Edmonton.

Rangelands, 9, 215-218.

In: Proceedings of International Baikal Symposium on hunting, game management and conservation of wildlife, Irkutsk, USSR

Canadian Game Farmer and Bison Journal, June, 3-6.

Ch. 13. In: Wildlife production systems: economic utilization of wild ungulates. Hudson, R.J., Drew, K.R. and Baskin, L.M. (ed.). Cambridge University Press, Cambridge, UK.

Proceedings of Alberta Game Growers' Association. Red Deer.

2nd International Moose Symposium. Sweden.

Second International Moose Symposium, Swedish Wildlife Research, (in press).

Canadian Wildlife Service, Edmonton. Unpublished report.

pp. 104-106. In: Proceedings of the 3rd Annual Alberta Game Growers' Association Conference. Renecker L.A. (ed.). Red Deer, Oct. 23-24, 1987.

Proceedings of the Circumpolar Conference on Northern Ecology. Ottawa, ON, Sept. 15-18, 1975.

pp. 91-101. In: Proceedings of grazing systems seminar. Kamloops, BC., June 11-12, 1980.

Journal of Range Management, 28, 172-180.

M.Sc. Thesis. University of Alberta, Edmonton.

Applied Animal Ethology, 7, 87-102. 


\begin{tabular}{|c|c|c|c|}
\hline Author(s) / Editor & Date & Title & Journal / Conference / Etc. \\
\hline Anonymous. & 1985 & $\begin{array}{l}\text { Wildlife productivity and management program; annual } \\
\text { report. }\end{array}$ & $\begin{array}{l}\text { Department of Animal Science, University of } \\
\text { Alberta, Edmonton. }\end{array}$ \\
\hline Banfield, A.W.F. & 1950 & The barren-ground caribou, 1950. & $\begin{array}{l}\text { Canadian Wildlife Service, Ottawa. Unpublished } \\
\text { report. }\end{array}$ \\
\hline Banfield, A.W.F. & 1950 & $\begin{array}{l}\text { White-tailed deer Odocoileus virginianus in Jasper } \\
\text { National Park, Alberta. }\end{array}$ & Canadian Field Naturalist, 61, 44. \\
\hline Bradford, W. & 1986 & $\begin{array}{l}\text { A discussion of elk (Cervus elaphus), moose (Alces } \\
\text { alces), sheep (Ovis canadensis) and wolf (Canis lupus) in } \\
\text { Jasper National Park. }\end{array}$ & Parks Canada, Calgary. Unpublished report. \\
\hline Briscoe, B.W. (ed.). & 1980 & Wood Buffalo National Park research 1978 annual report. & $\begin{array}{l}\text { Canadian Wildlife Service, Edmonton. } \\
\text { Unpublished report. }\end{array}$ \\
\hline Brown, W.K. & 1989 & $\begin{array}{l}\text { Greater Jasper ecosystem caribou research project, } \\
\text { progress report, October } 1988 \text { - April } 1989 .\end{array}$ & Parks Canada, Calgary. Unpublished report. \\
\hline Brown, W.K. & 1989 & $\begin{array}{l}\text { Greater Jasper ecosystem caribou research project, } \\
\text { progress report, May } 1989 \text { - October } 1989 .\end{array}$ & Parks Canada, Calgary. Unpublished report. \\
\hline Brown, W.K. & 1990 & $\begin{array}{l}\text { Greater Jasper ecosystem caribou research project, } \\
\text { progress report, November } 1989 \text { - March } 1990 .\end{array}$ & Parks Canada, Calgary. Unpublished report. \\
\hline Brown, W.K. & 1991 & $\begin{array}{l}\text { Greater Jasper ecosystem caribou research project, } \\
\text { progress report, A pril } 1990 \text { - January } 1991 .\end{array}$ & Parks Canada, Calgary. Unpublished report. \\
\hline DeBock, E.A. & 1970 & A report of the Willmore Wilderness goat project. & $\begin{array}{l}\text { Alberta Fish and Wildlife Division, Edmonton. } \\
\text { Unpublished report. }\end{array}$ \\
\hline $\begin{array}{l}\text { Edmonds, E.J., and Bloomfield, } \\
\text { M.I. }\end{array}$ & 1984 & $\begin{array}{l}\text { A study of woodland caribou (Rangifer tarandus caribou) } \\
\text { in west central Alberta, 1979-1983. }\end{array}$ & $\begin{array}{l}\text { Alberta Fish and Wildlife Division, Edmonton. } \\
\text { Unpublished report. }\end{array}$ \\
\hline Festa-Bianchet, $\mathrm{M}$. & 1989 & The sheep river bighorn sheep study. & Caprinae News (IUCN), 4, 12-14. \\
\hline Flook, D.R. & 1970 & A study of apparent unequal sex ratio of wapiti. & Ph.D. Thesis. University of Alberta, Edmonton. \\
\hline Fuller, W.A. & 1966 & $\begin{array}{l}\text { The biology and management of the bison of Wood } \\
\text { Buffalo National Park. }\end{array}$ & $\begin{array}{l}\text { Canadian Wildlife Service, Edmonton. Wildlife } \\
\text { Management Bulletin Service No. } 1 .\end{array}$ \\
\hline Geist, V., and Francis, M. & 1990 & Mule deer country. & Northword Press. Minocqua, Wisconsin. \\
\hline Geist, V. and Francis, M. & $\begin{array}{l}\text { (in } \\
\text { press) }\end{array}$ & Elk Country. & Northword Press, Minocqua, Wisconsin. \\
\hline Green, H.U. & 1957 & Notes on the elk of Banff National Park. & Canada Parks Service report. \\
\hline Jorgenson, J.T. & 1987 & $\begin{array}{l}\text { Mount Allen Bighorn sheep project, 2nd progress report: } \\
\text { Nov. } 1986 \text { - April } 1987\end{array}$ & $\begin{array}{l}\text { Alberta Fish and Wildlife Division, Calgary. } \\
\text { Unpublished Report. }\end{array}$ \\
\hline Jorgenson, J.T. & 1987 & $\begin{array}{l}\text { Mount Allen Bighorn sheep project progress report: May } \\
1985 \text { - August } 1986\end{array}$ & $\begin{array}{l}\text { Alberta Fish and Wildlife Division, Calgary. } \\
\text { Unpublished Report. }\end{array}$ \\
\hline Jorgenson, J.T. & 1989 & $\begin{array}{l}\text { Ram mountain bighorn sheep study, 9th progress report - } \\
1986-1988 \text {. }\end{array}$ & $\begin{array}{l}\text { Alberta Fish and Wildlife Division, Edmonton. } \\
\text { Unpublished report. }\end{array}$ \\
\hline $\begin{array}{l}\text { Jorgenson, J.T., and Wishart, } \\
\text { W.D. }\end{array}$ & 1986 & $\begin{array}{l}\text { Ram Mountain bighorn sheep project progress report } \\
\text { (1984 and 1985). }\end{array}$ & $\begin{array}{l}\text { Alberta Fish and Wildlife Division, Edmonton. } \\
\text { Unpublished report. }\end{array}$ \\
\hline Jorgenson, J.T. and Wishart, W.D. & 1987 & $\begin{array}{l}\text { Ram Mountain bighom sheep project progress report. } \\
\text { May } 1985 \text { - August, } 1986 .\end{array}$ & $\begin{array}{l}\text { Alberta Fish and Wildlife Division, Edmonton. } \\
\text { Unpublished report. }\end{array}$ \\
\hline Kansas, J.L. & 1991 & $\begin{array}{l}\text { A conservation strategy approach to Woodland Caribou } \\
\text { research in west-central Alberta. }\end{array}$ & $\begin{array}{l}\text { Abstract from Alberta Chapter of the Wildlife } \\
\text { Society, 2nd Annual meeting. March } 23 \text { and 24, } \\
\text { 1991, Edmonton. }\end{array}$ \\
\hline Kerr, G.R. & 1965 & The ecology of mountain goats in west central Alberta. & M.Sc. Thesis. University of Alberta, Edmonton. \\
\hline Kramer, A. & 1971 & $\begin{array}{l}\text { A review of the ecological relationships between mule and } \\
\text { white-tailed deer. }\end{array}$ & $\begin{array}{l}\text { Alberta Fish and Wildlife Division, Edmonton. } \\
\text { Unpublished report. }\end{array}$ \\
\hline McFetridge, R.J. & 1974 & $\begin{array}{l}\text { Mountain goat population research on the Grande Cache } \\
\text { area of Alberta, progress report. }\end{array}$ & $\begin{array}{l}\text { Alberta Fish and Wildlife Division, Edmonton. } \\
\text { Unpublished report. }\end{array}$ \\
\hline Millar, J.B. & 1953 & $\begin{array}{l}\text { An ecological study of the moose in the Rock Lake area of } \\
\text { Alberta. }\end{array}$ & M.Sc. Thesis. University of Alberta, Edmonton. \\
\hline Miller, F.L. & 1982 & Caribou. Chapter 47. & $\begin{array}{l}\text { In: Wild mammals of North America; biology, } \\
\text { management and economics. Chapman, J.A. and } \\
\text { Feldhamer, G.A. (eds.). John Hopkins } \\
\text { University Press, Baltimore, MD. }\end{array}$ \\
\hline
\end{tabular}




\begin{tabular}{|c|c|c|}
\hline Author(s) / Editor & Date & Title \\
\hline Mitchell, G.J. & 1965 & $\begin{array}{l}\text { Natality, mortality and related phenomena in two } \\
\text { populations of pronghorn antelope in Alberta, Canada. }\end{array}$ \\
\hline Mitchell, G.J. & 1980 & The pronghorn antelope in Alberta. \\
\hline Morgantini, L.E. & 1978 & $\begin{array}{l}\text { Ecology and behavior of the Banff Ya-Ha-Tinda elk herd } \\
\text { and the effects of harassment. }\end{array}$ \\
\hline Morgantini, L.E. & 1988 & $\begin{array}{l}\text { Prairie Bluff bighorn sheep study. IV. Progress report: } \\
\text { January/September } 1988 \text {. }\end{array}$ \\
\hline Morgantini, L.E. & 1989 & $\begin{array}{l}\text { Prairie Bluff bighorn sheep study. V. Progress report: } \\
\text { October 1988-October } 1989 .\end{array}$ \\
\hline Morgantini, L.E. & 1991 & $\begin{array}{l}\text { Prairie bluff. Bighorn sheep study. Final report Part 1: } \\
\text { Summary and conclusions. }\end{array}$ \\
\hline Pattie, D.L. and Hoffmann, R.S. & 1990 & $\begin{array}{l}\text { Ungulates pp. 504-575. In: Mammals of North America } \\
\text { Parks and Prairies. }\end{array}$ \\
\hline $\begin{array}{l}\text { Reynolds, H.W. and Hawley, } \\
\text { A.W.L. (eds.). }\end{array}$ & 1987 & $\begin{array}{l}\text { Bison ecology in relation to agricultural development in the } \\
\text { Slave River lowlands, N.W.T. }\end{array}$ \\
\hline $\begin{array}{l}\text { Reynolds, H.W., Glaholt, R.D. } \\
\text { and Hawley, A.W.L. }\end{array}$ & 1982 & Bison. Chapter 49. \\
\hline Russell, A. & 1973 & Homs in the high country. \\
\hline Shackleton, D.M. & 1985 & Ovis canadensis. \\
\hline Sheppard, D.H. & 1960 & The ecology of the mule deer of the Sheep River region. \\
\hline Skjonsberg, T. & 1990 & Eastern slopes wildlife study: 1984-1987. \\
\hline
\end{tabular}

Soper, J.D.

Staples, F.

Stelfox, J.G.

Stelfox, J.G.

Stelfox, J.G.

Thomas, D.C.

Trefethen, J.B. (ed.)

van Zyll de Jong, C.G.

Wishart, W.

Wishart, W.

Wishart, W.
1941

History, range and home life of the northern bison.

1987 Smokey district caribou study.

1976 Range ecology of Rocky Mountain bighorn sheep.

1976 Wood Buffalo National Park bison research, 1972-1976, 1976 annual report.

1977 Wood Buffalo National Park bison research, 1977 annual report.

1990 A study of woodland caribou in Jasper National Park, 1988-89 through 1992-93. Project proposal.

1986 A systematic study of recent bison, with particular consideration of the wood bison.

1958 The bighom sheep of the Sheep River Valley.

1978 Bighorn sheep. Chapter 11.

1985 The Wainwright deer herd (1966-1984): a comparative study of white-tails and mule deer.
1975 The wild sheep in modern North America.
Journal / Conference / Etc.

Ph.D. Thesis. Washington State University, Pullman, WA.

University of Regina Press, Regina, SK.

Prepared for Parks Canada, Calgary; prepared by Department of Animal Science, University of Alberta, Edmonton. Unpublished report.

Report prepared for Shell Canada Ltd. Prepared by Wildlife Resources Consultants Ltd. 20 pp.

Report prepared for Shell Canada Ltd. Prepared by Wildlife Resources Consultants Ltd. 46 pp.

Prepared for Shell Canada Ltd. Prepared by Wildlife Resources Consulting.

Printed by authors, Edmonton, Alberta.

Canadian Wildlife Service Occasional Paper Number 63. Edmonton.

pp. 972-1007. In: Wild mammals of North America. Chapman, J.A. and Feldhamer, G.A. (eds.). John Hopkins University Press, Baltimore, MD.

Alfred A. Knopf, New York, NY.

Mammalian Species, 230, 1-9.

M.Sc. Thesis. University of Alberta, Edmonton.

Prepared for Parks Canada, Calgary. Prepared by Canadian Wildlife Service, Edmonton. Unpublished report.

Ecological Monograph, 11, 348-412.

Parks Canada, Calgary. Unpublished report.

Canadian Wildlife Service Report Series Number 39. Edmonton.

Canadian Wildlife Service, Edmonton. Unpublished report.

Canadian Wildlife Service, Edmonton. Unpublished report.

Canadian Wildlife Service, Edmonton. Unpublished report.

Boone \& Crockett Club, New York, NY.

National Museums of Canada, Publications in Natural Sciences No. 6.

M.Sc. Thesis. University of Alberta, Edmonton.

In: Big game of North America: ecology and management. Schmidt, J.L. and Gilbert, D.L. (eds.). Stackpole Books, Harrisburg, PA

Alberta Fish and Wildlife Division, Edmonton. Unpublished report. 


\begin{tabular}{|c|c|c|}
\hline Author(s) / Editor & Date & Title \\
\hline Allison, $\mathbf{L}$. & 1972 & The status of moose on the Peace-Athabasca delta. \\
\hline Allison, L. & 1973 & The status of bison on the Peace-Athabasca delta. \\
\hline Anderson, R.M. & 1938 & $\begin{array}{l}\text { Investigation into wildlife conditions in national parks } \\
\text { (Waterton Lakes, Banff and Jasper) in the province of } \\
\text { Alberta, 1938. }\end{array}$ \\
\hline Anonymous. & 1968 & Cloven-hoofed animals of Alberta. \\
\hline Anonymous. & 1973 & $\begin{array}{l}\text { The wildlife resource of the "Willmore Wilderness Parl } \\
\text { area. }\end{array}$ \\
\hline Anonymous. & 1975 & Eastern slopes, fish and wildlife resources. \\
\hline Anonymous. & 1983 & Wood bison area. \\
\hline Anonymous. & 1984 & Status of the fish and wildlife resource in Alberta. \\
\hline
\end{tabular}

Anonymous.

1987 Population estimates of mule deer and white-tailed deer in Alberta.

Arbuckle, R.

1983 Peace River region caribou telemetry program, 1982-83 progress report.

Arbuckle, R.

1984 Summary report of the 1983-84 caribou monitoring program near Chisholm, Alberta.

Arbuckle, R.

1985 Summary report of the 1983-1984 caribou monitoring program near Dixonville, Alberta.

Armstrong, G.G.

1966 Antelope status, 1966.

Armstrong, G.G.

1967 Antelope status, 1967.

Armstrong, G.G.

1968 Bighorn sheep and mountain goat status in WMU F302, F306, F308, S400 and S402.

Armstrong, G.G.

1968 Status of big game in the foothills and subalpine areas region 1, Lethbridge.

Armstrong, G.G.

Armstrong, G.G.

Banfield, A.W.F.

Banfield, A.W.F.

Banfield, A.W.F.

Banfield, A.W.F.

Banfield, A.W.F.

Barrett, M.W.

Bergerud, A.T.

Blood, D.A.

Brady, K.S.
Progress report on bighorn sheep investigations in the Rocky Mountain national parks.

1968 Status of prairie deer, 1967-68.

1969 Status of the Oldman elk herd.

1946 Report on the wildlife conditions in Waterton Lakes National Park, 1946.

1946 Report on wildlife conditions in Elk Island National Park, 1946.

1946 Report on wildlife conditions in mountain national parks, 1946.

1949 The present status of North American caribou.

1958 The mammals of Banff National Park, Alberta.

1980 Alberta provincial report.

1980 Status of Rangifer in Canada. 1. Woodland caribou (Rangifer tarandus caribou).

1975 A report on wildlife numbers and distribution, period January 1974 - February, 1975: Waterton Lakes National Park.

Journal / Conference / Etc.

In: Ecological investigations technical appendixes

2. Environment Canada, Ottawa, ON.

In: Ecological investigations technical appendixes 2. Environment Canada, Ottawa, ON.

Canadian Wildlife Service, Edmonton. Unpublished report.

Alberta Lands, Forests, Parks, Wildlife, 11, 3-13.

Alberta Fish and Wildlife Division, Edmonton. Unpublished report.

Alberta Fish and Wildlife Division, Edmonton. Unpublished report.

Parks Canada, Calgary. Unpublished report.

Natural Resources, Fish and Wildlife Division Edmonton. Publication No. 1/87.

Alberta Fish and Wildlife Division, Edmonton. Unpublished report.

Alberta Fish and Wildlife Division, Edmonton. Unpublished report.

Alberta Fish and Wildlife Division, Edmonton. Unpublished report.

Alberta Fish and Wildlife Division, Edmonton. Unpublished report.

Alberta Fish and Wildlife Division, Edmonton. Unpublished report.

Alberta Fish and Wildlife Division, Edmonton. Unpublished report.

Alberta Fish and Wildlife Division, Edmonton. Unpublished report.

Alberta Fish and Wildlife Division, Edmonton. Unpublished report.

Alberta Fish and Wildlife Division, Edmonton. Unpublished report.

Alberta Fish and Wildlife Division, Edmonton. Unpublished report.

National Parks Bureau, Ottawa, ON. Unpublished report.

National Parks Bureau, Ottawa, ON. Unpublished report.

National Parks Bureau, Ottawa, ON. Unpublished report.

Transactions of North American Wildlife Conference, 14, 477-491.

National Parks Bureau, Ottawa, ON.

pp. 13. In: In proceedings of the 9th Biennial Pronghom Antelope Workshop. Rio Rico, AZ, April 7-10, 1980

pp. 748-753. In: Proceedings of the 2 nd International Reindeer/Caribou Symposium. Reimers, E., Gaare, E. and Skjenneberg, S. (eds.). Roros, Norway.

Canadian Wildlife Service, Edmonton. Unpublished report.

Parks Canada, Calgary. Unpublished report. 


\begin{tabular}{|c|c|c|}
\hline Author(s) / Editor & Date & Title \\
\hline Brady, K.S. & 1976 & $\begin{array}{l}\text { A report on wildlife numbers and distribution, March } 1975 \\
\text { - March 1976: Waterton Lakes National Park. }\end{array}$ \\
\hline Brady, K.S. & 1977 & $\begin{array}{l}\text { A report on wildlife numbers and distribution, period } \\
\text { January } 1976 \text { - December 1976: Waterton Lakes National } \\
\text { Park. }\end{array}$ \\
\hline Brady, K.S. (compiler). & 1973 & $\begin{array}{l}\text { Ungulate abundance and distribution, Waterton Lakes } \\
\text { National Park. }\end{array}$ \\
\hline Briscoe, B.W. (ed.) & 1978 & $\begin{array}{l}\text { Wood Buffalo National Park bison research, } 1978 \text { annual } \\
\text { report. }\end{array}$ \\
\hline Burgess, T.E. & 1970 & Caribou in northwestern Alberta. \\
\hline Burgess, T.E. & 1973 & $\begin{array}{l}\text { Alberta mule deer: present status and management } \\
\text { considerations. }\end{array}$ \\
\hline Carnell, D. & 1982 & Marmot Basin goat-caribou study. Interim report. \\
\hline Carr, H.D. & 1968 & Status of game in region 2 . \\
\hline Carr, H.D. & 1969 & Status of game in region II. \\
\hline Carr, H.D. & 1972 & Status of elk in Alberta in 1972. \\
\hline Carr, H.D. & 1976 & $\begin{array}{l}\text { A summary of the development of Alberta's present elk } \\
\text { population. }\end{array}$ \\
\hline Carr, H.D. and Carruthers, D. & 1973 & Status of elk in big game zones 5,6 and 7 . \\
\hline
\end{tabular}

Clarke, C.H.D.

1941 Wildlife investigations in Banff and Jasper National Parks.

Clarke, J.

1983 Southern region prairie deer population estimates by wildlife management unit, 1983.

Collins, R.L.

1969 Big game inventory and habitat classification of mountain and foothill portions of the Sheep, Kananaskis and Bow River drainages.

Courtney, J.

1971 A report on the distribution and populations of ungulates in Waterton Lakes National Park.

Cowan, I. McT.

1940 Distribution and variation in the native sheep of North America.

Cowan, I. McT.

1943 Report on game conditions in Banff, Jasper and Kootenay National Parks, 1943.

Cowan, I. McT.

1944 Report on wildlife studies, Jasper, Banff, Yoho National Parks in 1944 and parasites, diseases and injuries of game animals in the Rocky Mountain national parks, 1942-1944.

Cowan, I. McT.

Demarchi, R.A.

1950 Some vital statistics of big game on overstocked mountain range.

1977 Canada's mountain sheep - their present status and future prospects.

Demarchi, R.A. and Demarchi, D.A.

Doherty, M.J.

Downing, S.C.

Dwyer, M.V.

Edmonds, J.E.

Egerton, P.J.M
1967 Status of the Rocky Mountain sheep.

A preliminary ecological investigation of the Soap Hole area in Elk Island National Park, Alberta.

The Rocky Mountain bighorn.

The ecological characteristics and historical distribution of the family Cervidae in Alberta.

Population status, distribution and movements of woodland caribou in west central Alberta.

1964 The bison in Canada: how it was saved from extinction and its management today.
Journal / Conference / Etc.

Parks Canada, Calgary. Unpublished report.

Parks Canada, Calgary. Unpublished report.

Parks Canada, Calgary. Unpublished report.

Environment Canada. Edmonton, Alberta.

Alberta Fish and Wildlife Division, Edmonton. Unpublished report.

Alberta Fish and Wildlife Division, Edmonton. Unpublished report.

Parks Canada, Calgary. Unpublished report.

Alberta Fish and Wildlife Division, Edmonton. Unpublished report.

Alberta Fish and Wildlife Division, Edmonton. Unpublished report.

Alberta Fish and Wildlife Division, Edmonton Unpublished report.

Alberta Fish and Wildlife Division, Edmonton Unpublished report.

Alberta Fish and Wildlife Division, Edmonton Unpublished report.

Canadian National Parks Bureau, Ottawa, ON. Unpublished report.

Alberta Fish and Wildlife Division, Edmonton Unpublished report.

Alberta Fish and Wildlife Division, Edmonton Unpublished report.

Canadian Wildlife Service, Edmonton.

Unpublished report.

American Midland Naturalist, 24, 505-580.

Parks Canada, Ottawa, ON. Unpublished report.

Parks Canada, Calgary. Unpublished report.

Transaction of North American Wildlife Conference, 15, 581-588.

pp. 46-50. In: Canada's threatened species and habitats. Mosquin, T. and Suchal, C. (eds.).

Canadian Nature Federation (Spec. Publ. No. 6).

Wildlife Review, 4, 10-14.

Canadian Wildlife Service, Edmonton. Unpublished report.

Naturaliste Canadien 12, 140.

M.Sc. Thesis. University of Alberta, Edmonton. Canadian Journal of Zoology, 66, 817-826.

Oryx, 7, 305-314. 


\begin{tabular}{|c|c|c|}
\hline Author(s) / Editor & Date & Title \\
\hline Fisher, H.D. & 1948 & $\begin{array}{l}\text { Report on the } 1948 \text { wildlife investigations, Banff National } \\
\text { Park. }\end{array}$ \\
\hline Flook, D.R. & 1955 & $\begin{array}{l}\text { Appraisal of elk situation in the Athabasca Valley of Jasper } \\
\text { Park. }\end{array}$ \\
\hline Flook, D.R. & 1955 & $\begin{array}{l}\text { Appraisal of elk situation, Waterton Lakes National Park, } \\
\text { October, } 1955 .\end{array}$ \\
\hline Flook, D.R. & 1962 & $\begin{array}{l}\text { Appraisal of elk situation, Banff Park, } 1962 \text { based on park } \\
\text { wardens' elk census. }\end{array}$ \\
\hline Gainer, B. & 1985 & Free-roaming bison in northern Alberta. \\
\hline Glasgow, W.M. & 1987 & $\begin{array}{l}\text { Status of white-tailed deer and mule deer in Alberta in } \\
1985 / 86 .\end{array}$ \\
\hline Green, H.U. & 1946 & The bighom sheep of Banff National Park. \\
\hline Green, H.U. & 1946 & The elk of Banff National Park. \\
\hline Green, H.U. & 1946 & The moose of Banff National Park. \\
\hline Gudmundson, L. & 1978 & Alberta provincial report. \\
\hline Hall, B. & 1977 & $\begin{array}{l}\text { Status and management of the Rocky Mountain goat } \\
\text { Oreamnos americanus in the province of Alberta. }\end{array}$ \\
\hline Hall, B. & 1982 & Alberta provincial report. \\
\hline $\begin{array}{l}\text { Harrison, G., Hooper, R. and } \\
\text { Jacobson, P. }\end{array}$ & 1982 & $\begin{array}{l}\text { Ungulate population statistics and habitat analysis, Banff } \\
\text { National Park. East gate to Sunshine turnoff. }\end{array}$ \\
\hline $\begin{array}{l}\text { Hebert, D., Wishart, W., } \\
\text { Jorgenson, J. and Festa-Bianchet, }\end{array}$ & 1985 & Bighorn status in Alberta and British Columbia. \\
\hline
\end{tabular}

Jorgenson, J. and Festa-Bianchet, M.

Hoffman, W.H.

Holroyd, G.L., Van Tighem, K.J., 1979 Skeel, M.A. and Kansas, J.L.

Holsworth, W.N.

1957 Report on the status of the Rocky Mountain bighorn sheep of Waterton Lakes National Park, Alberta and annotated list of the birds and mammals of Waterton Park.

Huestis, E.S.

1942 Report on game conditions in the Canadian provinces. From Alberta.

Jacobsen, P.

1977 Status of goats in Banff National Park.

Jacobsen, $P$.

Jacobsen, P. and Loewen, D.

Jacobson, P.

Jasper Park Warden Service.

Jones, V.R.

Karasiuk, D.S. and McIlveen, D.M. 1977

Karasiuk, D.S., Cole, L.M. and

Kaye, R.G.

Keillor, R. near Lake Louise, Banff.

Elk distribution and movements in the Bow Valley, winter period, 1980-1981. and surrounding Marmot Basin ski developments, Jasper National Park.

Elk Island National Park, a report on surplus moose and ,deer, December, 1971 and January, 1972.

An ungulate inventory of Banff and Jasper National Parks. IV. Athabasca Valley. Interim report. 1978.
Journal / Conference / Etc.

Canadian Wildlife Service, Edmonton. Unpublished report.

Canadian Wildlife Service, Edmonton. Unpublished report.

Canadian Wildlife Service, Edmonton. Unpublished report.

Canadian Wildlife Service, Edmonton. Unpublished report.

Alberta Naturalist, 15, 86-87.

Alberta Fish and Wildlife Division, Edmonton. Unpublished report.

Canadian Wildlife Service, Edmonton. Unpublished report.

Canadian Wildlife Service, Edmonton. Unpublished report.

Canadian Wildlife Service, Edmonton. Unpublished report.

pp. 5-6. In: Proceedings of the 8th Biennial Pronghom Antelope Workshop. Jasper, May 2-4, 1978.

Alberta Fish and Wildlife Division, Edmonton Unpublished report.

Proceedings of Biennial Pronghom Antelope Workshop, 10. 10-11.

Parks Canada, Calgary. Unpublished report.

pp. 48-55. In: Northern wild Sheep and Goat Council Workshop. Whitehorse, YK

Alberta Fish and Wildlife Division, Edmonton. Unpublished report.

Prepared by Canadian Wildlife Service, Edmonton, prepared for Parks Canada, Calgary. Unpublished report.

Canadian Wildlife Service, Edmonton. Unpublished report.

Transactions of North American Wildlife Conference, 7,12-13.

Parks Canada, Calgary. Unpublished report.

Parks Canada, National Resources Bulletin, 3 , 2-3.

Parks Canada, Calgary. Unpublished report.

Parks Canada, Calgary. Unpublished report.

Parks Canada, Calgary. Unpublished report.

Wildlife inventory of Jasper National Park. Interim report, Parks Canada, Calgary. Unpublished report.

Winter ungulate distribution in the southeast portion of WMU M522.
Parks Canada, Calgary. Unpublished report.

Parks Canada, Calgary. Unpublished report.

Alberta Fish and Wildlife Division, Edmonton. Unpublished report. 


\begin{tabular}{|c|c|c|}
\hline Author(s) / Editor & Date & Title \\
\hline Kelsall, J.P. and Telfer, E.S. & 1974 & $\begin{array}{l}\text { Biogeography of moose with particular reference to } \\
\text { western North America. }\end{array}$ \\
\hline Kerr, G.R. & 1966 & Goat and sheep range distribution. \\
\hline Kindle, E.M. & 1928 & Wildlife of Jasper park. \\
\hline Kjorlien, M. & 1969 & $\begin{array}{l}\text { A report on surplus elk, moose and deer December, } 1969 . \\
\text { Elk Island National Park. }\end{array}$ \\
\hline Kjorlien, M. & 1976 & $\begin{array}{l}\text { Status of wood bison (Bison bison athabascae), Elk Island } \\
\text { National Park. }\end{array}$ \\
\hline Kunelius, S. & 1985 & Bighorn sheep monitoring, Banff National Park, 1985. \\
\hline Loewen, A.B. & 1971 & $\begin{array}{l}\text { Bighorn sheep study, Disaster Point range, Jasper } \\
\text { National Park. }\end{array}$ \\
\hline Loewen, A.B. & 1975 & Wildlife distribution, Miette study area. \\
\hline Lynch, G.M. & 1969 & $\begin{array}{l}\text { Summary of game status, Edson biological region (spring, } \\
\text { 1969). }\end{array}$ \\
\hline Lynch, G.M. & 1971 & $\begin{array}{l}\text { Red Cap sheep; their movement and migrations (project } \\
\text { proposal). }\end{array}$ \\
\hline Lynch, G.M. & 1975 & Moose populations and seasons in Alberta. \\
\hline Lynch, G.M. & 1975 & Some movement patterns of Swan Hills moose. \\
\hline Lynch, G.M. & 1976 & $\begin{array}{l}\text { Some long-range movements of radio-tagged moose in } \\
\text { Alberta. }\end{array}$ \\
\hline Lynch, G.M. & 1980 & $\begin{array}{l}\text { Study of the movements and distribution of bighorn sheep } \\
\text { in the vicinity of a sheep sanctuary and a national park } \\
\text { boundary, Cadomin, Alberta. }\end{array}$ \\
\hline Lynch G.M. and Wishart, W. & 1975 & Bighorn ram movements at Cadomin (project proposal). \\
\hline
\end{tabular}

Lynch, G.M. and Wishart, W.

MacCallum, B.

1981

McFetridge, R.J.

1976

McFetridge, R.J.

1985

McFetridge, R.J. and Glasgow, W.M.

McLean, B.

Mitchell, G.J.

Mitchell, G.J.

Mitchell, G.J.

Mitchell, G.J.

Mitchell, K.B.

Mitchell, W.K.

Morgantini, L.E.

Morgantini, L.E.
Bighorn ram movements at Cadomin (project proposal).

Fish and wildlife resources in the proposed agricultural development area, Smith, Alberta.

Grande Cache mountain goat project.

Wapiti in the Peace River region - limit of the species range.

1976 Wildlife considerations on Wizard Lake and adjacent lands.

1974 The Ram Mountain sheep study, 1973.

Analysis of reports of big game conditions, 1951 and 1952 .

Deer population in the Porcupine Hills.

Review of the status of big game in southern Alberta, and recommendations for the 1956 season.

Status of big game in the Lower Bow-Crowsnest study area, 1957.

Wildlife conditions calendar year 1944, Banff National Park.

Report on elk in the Bow Valley.

Elk in the Canadian Rocky Mountains. The Panther-Red Deer-Clearwater region in Banff National Park.

1991 Movements and distribution of elk south-west of Pincher Creek. A three year study. Project update.
Journal / Conference / Etc.

Naturaliste Canadien, 101, 117-130.

Alberta Fish and Wildlife Division, Edmonton. Unpublished report.

Canadian Field Naturalist, 40, 111-118.

Parks Canada, Calgary. Unpublished report.

Parks Canada, Calgary. Unpublished report.

Parks Canada, Calgary. Unpublished report.

Parks Canada, Calgary. Unpublished report.

Jasper National Park, Parks Canada, Calgary. Unpublished report.

Alberta Fish and Wildlife Division, Edmonton. Unpublished report.

Alberta Fish and Wildlife Division, Edmonton. Unpublished report.

Alberta Fish and Wildlife Division, Edmonton. Unpublished report.

Alberta Fish and Wildlife Division, Edmonton. Unpublished report.

Proceedings of North American Moose Conference and Workshop, 12, 220-235.

Alberta Fish and Wildlife Division, Edmonton. Unpublished report.

Alberta Fish and Wildlife Division, Edmonton. Unpublished report.

Alberta Fish and Wildlife Division, Edmonton. Unpublished report.

Alberta Fish and Wildlife Division, Edmonton. Unpublished report.

pp. 196-205. In: Proceedings of 1984 Western States and Provinces Elk Workshop. Nelson, R.W. (ed.). Edmonton, April 17-19, 1984.

Alberta Fish and Wildlife Division, Edmonton. Unpublished report.

Alberta Fish and Wildlife Division, Edmonton. Unpublished report.

Alberta Fish and Wildlife Division, Edmonton. Unpublished report.

Alberta Fish and Wildlife Division, Edmonton. Unpublished report.

Alberta Fish and Wildlife Division, Edmonton. Unpublished report.

Alberta Fish and Wildlife Division, Edmonton. Unpublished report.

Parks Canada, Calgary. Unpublished report.

Canada Parks Service.

Prepared for Parks Canada, Calgary. Unpublished report.

Department of Forest Science, University of Alberta, Edmonton. 


\begin{tabular}{lcl}
\hline \multicolumn{1}{c}{ Author(s) / Editor } & Date & \multicolumn{1}{c}{ Title } \\
\hline Neave, D.J. & 1968 & Status of the Rocky Mountain goat in region III. \\
Novak, M. & 1968 & $\begin{array}{l}\text { Distribution of elk (Cervus canadensis) in north-east } \\
\text { Alberta. }\end{array}$ \\
Novak, M. & 1969 & $\begin{array}{l}\text { Distribution and abundance of some big game animals in } \\
\text { north-east Alberta during winter of 1967-68. }\end{array}$ \\
Novakowski, N.S. & 1959 & $\begin{array}{l}\text { Investigation of probable wood bison in the Nyarling } \\
\text { River area and an investigation of historical wood bison } \\
\text { range in the Fort Providence area. }\end{array}$
\end{tabular}

Novakowski, N.S.

1961 Estimates of the bison population, Wood Buffalo Park and the Northwest Territories based on transect and total counts, February 1971.

Novakowski, N.S.

1978 Status report on wood bison (Bison bison athabascae) in Canada.

Novakowski, N.S. and Stevens, 1965 Survival of the wood bison (Bison bison athabascae W.E.

Olson, W.

1985 An assessment of winter conditions, 1984/85, and their effect on the elk population of Elk Island National Park.

Pelchat, B., Young, B. and Carr, 1971 Status of elk in the Calgary region.

H.

Quaedvlieg, M.T., Boyd, M., Gunderson, G. and Cook, A.

Rand, A.L.

1973 Status of the Rocky Mountain goat in the province of Alberta.

1947 The 1945 status of the pronghorn antelope, Antilocapra americana (Ord), in Canada.

Reilander, $\mathbf{R}$.

1974 The moose of Moonshine Lake Provincial Park.

Rimmer, J.

1969 Notes on goats (Oreamnos americanus).

Rippin, B.

1979 A review of Alberta white-tailed deer status and proposal for future management.

Rosin, J. and Paulsen, A.C.

1973 Ya-Ha-Tinda elk tagging project and elk distribution observations for 1973 .

Schwanke, R. and Thope, B.

Ten-year ungulate report. Waterton Lakes National Park, 1970-1980.

Smith, K. and Wishart, W.

1977 Ram Mountain bighom sheep study progress report 1976.

Smith, K., Wishart, W. and Lynch, 1976 G.M.

Soper, J.D.

1934

Soper, J.D.

Soper, J.D.

Stelfox, J.G.

Stelfox, J.G.

1964

Stelfox, J.G.

Stelfox, J.G.

Stelfox, J.G.

Bighom ram movements at Cadomin, Alberta (1975-76 progress).

Canada's national buffalo herd.

Report on wildlife investigations in Wood Buffalo Park and vicinity, Alberta and Northwest Territories, Canada.

Stelfox, J.G.

Stelfox, J.G.
1964

The mammals of Alberta.

A preliminary survey of the distribution and abundance of big game and game birds in northem Alberta.

Bighorn study in the Coalbranch region (Drummond Creek south to Ruby Creek).

Elk in northwest Alberta.

Caribou populations in biological district \#3.

Caribou abundance and distribution in northwestem Alberta and proposed 1966 season.

Bighom sheep abundance and distribution in Banff, Jasper, Waterton Lakes and Kootenay National Parks, 1966-1967.

1969 Status of bighorn sheep at Vermilion Lakes, Banff National Park, May 1969.
Journal / Conference / Etc.

Alberta Fish and Wildlife Division, Edmonton. Unpublished report.

Alberta Fish and Wildlife Division, Edmonton. Unpublished report.

Alberta Fish and Wildlife Division, Edmonton. Unpublished report.

Canadian Wildlife Service, Edmonton; Parks Canada, Calgary. Unpublished report.

Canadian Wildlife Service, Edmonton; Parks Canada, Calgary. Unpublished report.

Committee on the Status of Endangered Wildlife in Canada.

Paper presented to American Society of Mammalogists. Winnipeg, MB

Parks Canada, Calgary. Unpublished report.

Alberta Fish and Wildlife Division, Edmonton. Unpublished report.

Alberta Fish and Wildlife Division, Edmonton. Unpublished report

National Museum of Canada Bulletin No. 106. Ottawa ON.

Parks Division, Alberta Department of Lands and Forests, Edmonton. Unpublished report.

Banff Warden Service. Parks Canada, Calgary. Unpublished report.

Alberta Fish and Wildlife Division, Edmonton Unpublished report.

Alberta Fish and Wildlife Division, Edmonton.

Parks Canada, Calgary. Unpublished report.

Alberta Fish and Wildlife Division, Edmonton. Unpublished report.

Alberta Fish and Wildlife Division, Edmonton. Unpublished report.

National Parks of Canada. Ottawa, ON.

National Parks Bureau, Winnipeg, MB

Unpublished report.

The Hamly Press Ltd., Edmonton.

Alberta Fish and Wildlife Division, Edmonton. Unpublished report.

Alberta Fish and Wildlife Division, Edmonton. Unpublished report.

Lands, Forest, Wildlife, 6, 14-23.

Alberta Fish and Wildlife Division, Edmonton. Unpublished report.

Alberta Fish and Wildlife Division, Edmonton. Unpublished report.

Canadian Wildlife Service, Edmonton.

Unpublished report.

Canadian Wildlife Service, Edmonton. Unpublished report. 


\begin{tabular}{|c|c|c|}
\hline Author(s) / Editor & Date & Title \\
\hline Stelfox, J.G. & 1974 & $\begin{array}{l}\text { The abundance and distribution of caribou and elk in } \\
\text { Jasper National Park, } 1971 \text { to } 1973 \text {. }\end{array}$ \\
\hline Stelfox, J.G. & 1978 & $\begin{array}{l}\text { Seasonal distributions of Rocky Mountain bighorn sheep } \\
\text { in Canadian National Parks: 1966-72. }\end{array}$ \\
\hline Stelfox, J.G. and Kerr, G. & 1962 & $\begin{array}{l}\text { The status of Rocky Mountain goats in the forested regio } \\
\text { of the Wildhay River and Pinto Creek areas in zone } 14 \text { ea } \\
\text { of the 6th Meridian and their prospects for survival. }\end{array}$ \\
\hline Stelfox, J.G. and Taber, R.D. & 1969 & $\begin{array}{l}\text { Big game in the northem Rocky Mountain coniferous } \\
\text { forest. }\end{array}$ \\
\hline Stelfox, J.G. (ed.) & 1976 & Wood Buffalo National Park, bison research 1972-74. \\
\hline Stenton, J.E. & 1962 & $\begin{array}{l}\text { The bighom sheep (Ovis canadensis) at Aylmer Lookout } \\
1950 \text { to } 1961 \text {. }\end{array}$ \\
\hline Telfer, E.S. & 1975 & Big game in the Alberta foothills. \\
\hline
\end{tabular}

Telfer, E.S.

Telfer, E.S.

Telfer, E.S. and Kelsall, J.P.

Thomas, D.C.

1991 Data on caribou and their environment in Jasper National Park, 1988-1991.

Van Camp, J.

The ungulates of Fish Creek Provincial Park.

Webb, R.

Webb, R.

Webb, R.

Wishart, W.

Wishart, W.

1966 Numbers, sex, age, and kill data of elk in biological district II, 1965 to 1966.

Wishart, W.

1970 A brief historic review of the pronghom antelope in Alberta.

Wishart, W.

Report from Alberta.

Wishart, W.

1984 Western Canada. Ch. 26.

Wishart, W. and Surrendi, C.

1967 Bird game and big game populations and harvests, summary for the central district, 1966.

Woods, J. G. and Haldy D.

1988 Elk movement in the Canadian Rockies Workshop. Cranbrook.

Woody, N.G.

1976 Status of the goat population - Jasper National Park.

Young, B.F.

Young, M.A.R.

1965 The buffalo at Filk Island Park.

Journal / Conference / Etc.

Canadian Wildlife Service, Edmonton. Unpublished report.

Canadian Wildlife Service, Edmonton. Unpublished report.

Alberta Fish and Wildlife Division, Edmonton. Unpublished report.

pp. 197-222. In: Proceeding of 1968 Symposium of Coniferous Forests of the Northern Rocky Mountains. University of Montana Foundation, Missoula, MT.

Canadian Wildlife Service, Edmonton. Unpublished report.

Banff National Park, Parks Canada, Calgary. Unpublished report.

University of Alberta Agriculture Bulletin, 26, 6-8. Edmonton.

pp. 145-182. In: Northem ecology and resource management. Olson, R., Geddes, F. and Hasting, R. (eds.). University of Alberta Press, Edmonton.

pp. 69-79. In: Proceedings of the 40th Annual Conference of International Union of Directors of Zoological Gardens. Calgary.

Naturaliste Canadien, 101, 117-130.

Prepared for Parks Canada, Calgary. Prepared by Canadian Wildlife Service, Edmonton. Unpublished report.

Prepared for Alberta Recreation, Parks and Wildlife; prepared by Lombard North Group, Calgary. Unpublished report.

Alberta Fish and Wildlife Division, Edmonton. Unpublished report.

Alberta Fish and Wildlife Division, Edmonton. Unpublished report.

Alberta Fish and Wildlife Division, Edmonton. Unpublished report.

Alberta Fish and Wildlife Division, Edmonton. Unpublished report.

Alberta Fish and Wildlife Division, Edmonton. Unpublished report.

Alberta Fish and Wildlife Division, Edmonton. Unpublished report.

pp. 22-29. In: The wild sheep in modern North America. Trefethen, J.B. (ed.). Winchester Press, New York, NY.

In: White-tailed deer: ecology and management. Halls, L.K. (ed.). Wildlife Management Institute. Stackpole Books, Harrisburg, PA.

Alberta Fish and Wildlife Division, Edmonton. Unpublished report.

Parks Canada, Calgary. Unpublished report.

Parks Canada, Calgary. Unpublished report.

Alberta Fish and Wildlife Division, Edmonton. Unpublished report.

Alberta Historical Review, 13, 26-28. 


\begin{tabular}{|c|c|c|}
\hline Author(s) / Editor & Date & Title \\
\hline $\begin{array}{l}\text { Baker, B.E., Blood, D.A. and } \\
\text { Chen, E.C.H. }\end{array}$ & 1967 & $\begin{array}{l}\text { Rocky Mountain bighom sheep (Ovis canadensis } \\
\text { canadensis) milk. II. Electrophoretic analyses of proteins, } \\
\text { carbohydrate content and casein. }\end{array}$ \\
\hline Blood, D.A. & 1966 & $\begin{array}{l}\text { Some characteristics of the moose of Elk Island National } \\
\text { Park, Alberta. }\end{array}$ \\
\hline $\begin{array}{l}\text { Blood, D.A., Flook, D.R. and } \\
\text { Wishart, W.D. }\end{array}$ & 1970 & $\begin{array}{l}\text { Weights and growth of Rocky Mountain bighorn sheep in } \\
\text { western Alberta. }\end{array}$ \\
\hline $\begin{array}{l}\text { Blood, D.A., McGillis, J.R. and } \\
\text { Lovaas, A.L. }\end{array}$ & 1967 & $\begin{array}{l}\text { Weights and measurements of moose in Elk Island } \\
\text { National Park, Alberta. }\end{array}$ \\
\hline Bullock. R.E. & 1971 & $\begin{array}{l}\text { A functional analysis of locomotion in the pronghom } \\
\text { antelope. }\end{array}$ \\
\hline Bullock, R.E. & 1974 & Functional analysis of locomotion in pronghorn antelope. \\
\hline
\end{tabular}

Bullock, R.E.

1982 An analysis of locomotor body movements in pronghorn antelope.

Chen, E.C.H., Blood, D.A. and Baker, B.E.

Cowan, I. McT. and McCrory, W. 1970

Eslinger, D.H.

Flook, D.R.

1958

Fuller, T.K. and Keith, L.B.

1980 Physical characteristics of woodland caribou in northeastem Alberta.

Fuller, W.A.

1948 Measurements and disease of buffalo, November December, 1948.

Gates, C.C. and Hudson, R.J. 1981 Weight dynamics of wapiti in the boreal forest.

Gauthier, D.A. and Farnell, R.F. 1986 Comparison of caribou physical characteristics from Yukon and neighboring caribou herds.

Geist, V.

1966 The evolution of hom-like organs.

Geist, V.

Geist, V.

Geist, V.

Geist, V

Geist, V.

Geist, V.

Geist, V.

Geist, V.

1991

Geist, V.

Geist, V. and Bayer, M.

Geist, V. and Bromley, P.T.

Guthrie, R.D. and Petocz, R.G.

On the interrelation of external appearance, social behavior and social structure of mountain sheep.

1972 On the significance of thermoclines to the biology of wintering mountain sheep.

1986 Why does antler size differ?

1987 Bergmann's rule is invalid.

1989 Environmentally guided phenotype plasticity in mammals and some of its consequences to theoretical and applied biology. sexual selection as a consequence of neonatal security strategies?

(in "Intraspecific variation in antler mass of the Cervidae is a press) function of neonatal survival strategy."

1988 Sexual dimorphism in the Cervidae and its relation to habitat.

1976 Why deer shed antlers.

1970 Weapon automimicry among mammals.
Journal / Conference / Etc.

Canadian Journal of Zoology, 45, 369-375.

Canadian Wildlife Service, Edmonton Unpublished report.

Journal of Wildlife Management, 34, 451-455.

Canadian Field Naturalist, 81, 263-269.

Ph.D. Thesis. University of Alberta, Edmonton.

pp. 274-305. In: The behavior of ungulates and its relation to management. Geist, V. and Walther, F. (eds.). IUCN, Switzerland.

Canadian Joumal of Zoology, 60, 1871-1880.

Canadian Journal of Zoology, 43, 885-888.

Journal of Mammalogy, 51, 60-73.

M.Sc. Thesis. University of Calgary, Calgary.

Canadian Wildlife Service, Edmonton. Unpublished report.

Canadian Field Naturalist, 94, 331-333.

Parks Canada, Calgary; Canadian Wildlife Service, Edmonton. Unpublished report.

Acta Theriologica, 26, 407-418.

Rangifer, Species Issue No. 1, 131-135.

Behaviour, 27, 175-214.

Joumal of Wildlife Management, 31, 192-194.

Nature, 220, 813-814.

J. Tierpsychol., 25, 199-215.

pp. 75-77. In proceedings of Northern Wild Sheep Council Symposium, Hinton.

Nature Canada, 14, 15-17.

Canadian Journal of Zoology, 65, 1035-1038.

Chapter 7. In: Alternative styles of animals. Edited by N.M. Bruton, Kluwer Academic Publisher, Dordrecht, Netherlands. pp. 153-176.

Applied Animal Behaviour Science, 29, 453-469.
Journal of Applied Animal Behavior Science,

Journal of Zoology (London), 214, 45-53.

Z. Saugetierk., 41, 223-231.

American Naturalist, 104, 585-588. 


\begin{tabular}{|c|c|c|}
\hline Author(s) / Editor & Date & Title \\
\hline $\begin{array}{l}\text { Haigh, J.C., Stewart, R.R. and } \\
\text { Mytton, W. }\end{array}$ & 1980 & $\begin{array}{l}\text { Relations among linear measurements and weights fo } \\
\text { moose (Alces alces). }\end{array}$ \\
\hline Hall, B. & 1973 & $\begin{array}{l}\text { Trophy sheep measurements - north of Bow River ar } \\
\text { summary of } 1973 \text { sheep harvested by week. }\end{array}$ \\
\hline Hawley, A.W.L. & 1986 & Carcass characteristics of bison (Bison bison) steers. \\
\hline Hutton, D.A. & 1972 & $\begin{array}{l}\text { Variation in the skulls and antlers of wapiti (Cervus } \\
\text { elaphus nelsoni Bailey). }\end{array}$ \\
\hline
\end{tabular}

Jorgenson, J.T. and Wishart, W.D. 1984

Kelsall, J.P. and Telfer, E.S.

1971

Studies of the physical adaption of big game for snow.

Kelsall, J.P., Telfer, E.S. and Kingsley, M.

Kelsall, J.P., Telfer, E.S. and Simpson, K.

Lewin, V. and Stelfox, J.G.

1978 Relationship of bison weight to chest girth.

1980 Indirect determination of ungulate foot area.

1967 Functional anatomy of the tail and associated behavior in woodland caribou.

McClymont, R.A., Fenton, M. and 1982 Thompson, J.R.

McClymont, R. and Thompson,

J.R.

Mitchell, G.J.

Novak, M.

1969

Novakowski, N.S.

1962 Growth and osteological comparisons of plains bison,

Peters, H.F, and Slen, S.B.

1964 Hair coat characteristics of bison, domestic $\mathrm{x}$ bison

Renecker, L.A.

1987

Renecker, L.A. and Hudson, R.J. 1990

Renecker, L.A. and Samuel, W.M. 1991

Retfalvi, L.

1969

Roberts, L.J.

1982

Shackleton, D.M.

1976

Shackleton, D.M., Hills, L.V. and Hutton, D.A.

Shank, C.C.

Stelfox, J.G.

Stelfox, J.G. and McGillis, J.R.

Stelfox, J.G. and Poll, D.M.

1978

Sugden, L.G. wood bison and possible hybrids. hybrids, cattalo, and certain domestic breeds of beef cattle.

Identification of cervid tissues and hybridization of serum albumin.

Fatty acid composition of white-tailed deer (Odocoileus virginianus), elk (Cervus canadensis) and moose (Alces alces) skeletal muscle and perinephric adipose tissue.

Measurements, weights, and carcass yields of pronghorns in Alberta.

An antlered doe.

The composition of moose milk following late parturition.

Digestive kinetics of moose, wapiti and cattle

Growth and seasonal weight changes as they relative to spring and autumn set points in mule deer.

Sexual dimorphism in fetuses of wapiti, Cervus canadensis.

The formation and application of a technique, based on phalanges, for discriminating the sex of plains bison.

Variability in physical and social maturation between bighom sheep (Ovis canadensis canadensis Shaw) populations.

Aspects of variation in cranial characters of plains bison (Bison bison bison Linnaeus) from Elk Island National Park, Alberta.

Sexual dimorphism in the ecological niche of wintering Rocky Mountain bighorn sheep.

Rectal prolapse in bull bison, Wood Buffalo National Park, August 27, 1975.

Seasonal growth patterns of bighoms correlated with range conditions and endoparasite loads.

Weights, measurements and tooth replacement of Rocky Mountain sheep in Canadian National Parks, 1967-1971.
Journal / Conference / Etc.

Proceedings of North American Moose Conference and Workshop, 16, 1-10.

Alberta Fish and Wildlife Division, Edmonton. Unpublished report.

Canadian Joumal of Animal Science, 66, 293-295.

M.Sc. Thesis. University of Calgary, Calgary.

pp. 270-284. In: Proceedings of the Fourth Biennial Symposium of the Northern wild Sheep and Goat Council. Hoefs, M. (eds.).

Whitehorse, YK

Paper presented at Snow and Ice Symposium. Iowa State University, Ames, IA, Feb. 11-12, 1971.

Journal of Wildlife Management, 42, 659-661.

Canadian Journal of Zoology, 58, 464-466.

Canadian Field Naturalist, 81, 63-66.

Journal of Wildlife Management, 46, 540-544.

University of Alberta, Edmonton. Unpublished report.

Joumal of Wildlife Management, 35, 76-85.

Alberta, Lands, Forests, Parks, Wildlife, 12, 42.

Canadian Wildlife Service, Edmonton.

Unpublished report.

Canadian Journal of Animal Science, 44, 48-557.

Acta. Theriol., 32, 117-121.

Animal Production, 50, 51-61.

Canadian Journal of Zoology, 69, 744-747.

Canadian Journal of Zoology, 47, 1418-1419.

University of Manitoba, Winnipeg, MB.

pp. 1-8. In: Proceedings of the Biennial Symposium of the North Wild Sheep Council. Jackson, WY.

Journal of Mammalogy, 56, 871-887.

Ph.D. Thesis. University of Calgary, Calgary.

Canadian Wildlife Service, Edmonton. Unpublished report.

Transactions of Northem Wild Sheep Conference. Williams Lake, BC.

Prepared for Parks Canada, Calgary; prepared by Canadian Wildlife Service, Edmonton. Unpublished report.

Journal of Mammalogy, 45, 490 . 


Author(s) / Editor
Telfer, E.S. and Kelsall, J.P.
Telfer, E.S. and Kelsall, J.P.
Telfer, E.S., Kingsley, M. and
Kelsall, J.P.
Webb, S.
Wishart, W.D.
Wishart, W.D.
Wishar, W.D.
Wishart, W.D.
Wood, A.J., Cowan, I. McT. and
Nordan, H.C.

Date
Title

1979 Studies of morphological parameters affecting ungulate locomotion in snow.

1984 Adaptations of some large North American mammals for survival in snow.

1976 Relationship of bison weight to chest girth.

1974 Positive identification of big game meat through electrophoresis and related techniques.

1969 Bighorns and little horns.

1980 Perukes in wild moose.

1985 Frequency of antlered white-tailed does in Camp Wainwright, Alberta.

1990 Velvet-antlered female moose (Alces alces).

1962 Periodicity of growth in ungulates as shown by deer of the genus Odocoileus.
Journal / Conference / Etc.

Canadian Journal of Zoology, 57, 2153-2159.

Ecology, 65, 1828-1834.

Canadian Wildlife Service, Edmonton. Unpublished report.

Alberta Fish and Wildlife Division, Edmonton. Unpublished report.

Alberta Lands-Forests-Parks-Wildlife, 12, 4-10.

Canadian Field Naturalist, 94, 458-459.

Journal of Wildlife Management, 49, 386-388.

Alces, 64-65

Canadian Journal of Zoology, 40, 593-603. 


Author(s) / Editor Date Title Journal / Conference / Etc.

Beak Associates Consulting.

A prototype assessment of wildlife resource status of the Wapiti (83L) NTS map sheet.

Bibaud, A.

Bibaud, A.

Notes on ungulate capability for the Saddle Hills.

Carr, $\mathrm{H}$.

Clark, J.

Eccles, R. and Stelfox, H.

Suffield winter habitat survey.

Big game inventory and habitat classification of mountain and foothill areas in region II.

Alberta (1979) antelope range classification.

Habitat evaluation techniques in Alberta.

Eng, M. and Stelfox, H.A.

Hawley, A.W.L.

(in A prototype assessment of wildlife resource status of the prep.) Rocky Mountain House (83B) NTS map sheet using an ecological land classification approach.

Holroyd, G.L. and Van Tighem, K.J.

Hoskin, B.J.

1985

1983

Remote sensing of wildlife habitat.

Ecological (biophysical) land classification of Banff and Jasper National Parks. Vol. III: the wildlife inventory.

1983 Catalogue of wildlife habitat mapping projects in Alberta.

I.E.C. Beak Consultants Ltd.

I.E.C. Beak Consultants Ltd.

I.E.C. Beak Consultants Ltd.

1985 A prototype assessment of wildlife resource status of the Rocky Mountain House (83B) NTS map sheet.

Jamieson, B.

Jaques, D.

Big game inventory and habitat classification of mountain and foothills portion of the Highwood, Elbow and Ghost River drainages. the provincial overview assessment of wildlife resource management.

Final report on the wildlife habitat region/subregion evaluation legend for the provincial overview of wildlife resource status.

Winter alpine-subalpine wildlife habitat in the southern Rocky Mountains of Alberta.

Jaques, D.

Jaques, D.

Jaques, D.

Biophysical classification, effects of grazing and biomass estimation using LANDSAT imagery on native fescue grasslands of southwestern Alberta.

Ecological analysis of wildlife habitat in Red Deer County, Alberta.

Jaques, D.

1980

Ecological (biophysical) classification of Kananaskis Country for wildlife habitat management and manipulation.

Kerr, D.S

1982 Application of ecological land classification to ungulate

Klar, A. and Stelfox, H. habitat analysis in the Porcupine Hills, southwestern Alberta.

LANDSAT mapping of and range condition on critical winter snow-free wildlife habitat in southwestern Alberta.

A guide to remote sensing interpretation for reconnaissance vegetation cover mapping and wildlife resource assessment.
Prepared for Alberta Fish and Wildlife Division, Edmonton. Unpublished report.

Alberta Fish and Wildlife Division, Edmonton. Unpublished report.

Alberta Fish and Wildlife Division, Edmonton. Unpublished report.

Alberta Fish and Wildlife Division, Edmonton. Unpublished report.

Alberta Fish and Wildlife Division, Edmonton. Unpublished report.

In: Proceeding of Symposium on Fish and Wildlife Management in Alberta: Current Practice - Future Strategies. Alberta Society of Professional Biologists, Edmonton.

Ecological Land Classification Series No. 22.In: Land/wildlife integration No. \#3.Environment Canada, Ottawa, ON

Alberta Environment Centre, Vegreville.

Canadian Wildlife Service, Edmonton. Unpublished report.

Wildlife Habitat Inventory Unit, Alberta Fish and Wildlife Division, Edmonton. Unpublished report.

Prepared for Alberta Fish and Wildlife Division, Edmonton. Unpublished report.

Prepared for Alberta Fish and Wildlife Division, Edmonton. Unpublished report.

Prepared for Alberta Fish and Wildlife Division, Edmonton. Unpublished report.

Alberta Fish and Wildlife Division, Edmonton. Unpublished report.

Prepared by Kananaskis Centre; prepared for Environmental Research, University of Calgary, Calgary. Unpublished report

Prepared for Alberta Fish and Wildlife Division, Edmonton, prepared by Kananaskis Centre for Environmental Research, University of Calgary, Calgary. Unpublished report.

Prepared for Alberta Fish and Wildlife Division, Edmonton, prepared by Kananaskis Centre for Environmental Research, University of Calgary, Calgary. Unpublished report.

Prepared for Alberta Fish and Wildlife Division, Edmonton, prepared by Kananaskis Centre for Environmental Research, University of Calgary, Calgary. Unpublished report.

Prepared for Alberta Fish and Wildlife Division, Edmonton, prepared by Kananaskis Centre for Environmental Research, University of Calgary, Calgary. Unpublished report.

M.Sc. Thesis. University of Calgary, Calgary.

Wildlife Resource Inventory Unit. Alberta Fish and Wildlife Division, Edmonton. Unpublished report. 


\begin{tabular}{lcl}
\hline \multicolumn{1}{c}{ Author(s) / Editor } & Date & \multicolumn{1}{c}{ Title } \\
\hline Knapik, L. and Westworth, D.A. & 1984 & $\begin{array}{l}\text { Final report; preliminary wildife habitat } \\
\text { regions/subregions of Alberta. }\end{array}$ \\
$\begin{array}{l}\text { Knapik, L.J., Russell, W.B., } \\
\text { Bessie, K. and Eng, M. }\end{array}$ & 1985 & $\begin{array}{l}\text { Wildlife habitat district mapping and inventory prototype } \\
\text { for the Wapiti map sheet (83L). }\end{array}$ \\
$\begin{array}{l}\text { Markham, B. } \\
\text { Morgantini, L. and Bruns, E. }\end{array}$ & 1972 & $\begin{array}{l}\text { Key habitat for ungulates and waterfowl in Alberta. } \\
\text { The assessment of three elk winter ranges in Alberta: an }\end{array}$ \\
\hline
\end{tabular}

Morgantini, L.E. and Russell, W.B. 1983

Olson, R.

1984 A winter-climate severity index and climate data base for ungulates by wildlife habitat regions/subregions in Alberta.

Ross, G.A. and Aronoff, S.

Russell, W., Annas, R. and Knapik, L.

Russell, W.B.

Stelfox, H.A.

Stelfox, H.A.

Stringer, P.W.

1968

A preliminary report on the description, classification and ecology of low-elevation grasslands in Banff, Jasper, and Waterton Lakes National Parks.

Strong, W.L. and Anderson, H.G. 1980 Ecological land classification and evaluation reference manual.

Strong, W.L. and Leggat, K.R. 1981 Ecoregions of Alberta.

Strong, W.L. and Vriend, H.G. 1980 Ecological land classification hierarchies and elk distribution in southwestern Alberta.

Van Tighem, K. and Holroyd, G.

1981

Inventorying wildlife in a biophysical framework.

Weatherhill, R.G.

1966 Canada land inventory Alberta ungulate wildlife capability classification project June 1965-May 1966.
Journal / Conference / Etc.

Prepared by Pedocan Land Evaluation Ltd., prepared for Alberta Fish and Wildlife Division, Edmonton. Unpublished report.

Prepared by Pedocan Land Evaluation Ltd., prepared for Alberta Fish and Wildlife Division, Edmonton. Unpublished report.

Alberta Fish and Wildlife Division, Edmonton. Unpublished report.

pp. 106-116. In: Proceedings of 1984 Western States and Provinces Elk Workshop. Edmonton, April 17-19, 1984.

Prepared for Alberta Fish and Wildlife Division, prepared by Wildland Resources Consultants Ltd., Edmonton. Unpublished report.

Prepared by Environmental Climate Services, prepared for Alberta Fish and Wildlife Division, Edmonton. Unpublished report.

Department of Environmental Science. University of Calgary, Calgary. Unpublished report.

Prepared by Pedocan Land Evaluation Ltd., prepared for Alberta Fish and Wildlife Division, Edmonton. Unpublished report.

Prepared for Alberta Fish and Wildlife Division Edmonton; prepared by Russell Ecological Consultants. Unpublished report.

Energy and Natural Resources report number: T/11-No. 8, Edmonton. Unpublished report.

pp. 117-124. In: Land/wildlife integration, No. 2. Ecological Land Classification Series, No. 17. Lands Directorate Environment Canada. Ottawa, ON.

Canadian Wildlife Service, Edmonton. Unpublished report.

Alberta Energy and Natural Resources, Edmonton.

Energy and Natural Resources Technical report number $\mathrm{T} / 4$. Edmonton.

pp. 99-106. In: Land/wildlife integration, No. 2. Ecological Land Classification Series, No. 2. Lands Directorate, Environment Canada. Ottawa, ON.

In: Symposium on census and inventory methods for population and habitats.

Alberta Fish and Wildlife Division, Edmonton. Unpublished report. 


\begin{tabular}{lcl}
\hline \multicolumn{1}{c}{ Author(s) / Editor } & Date & \multicolumn{1}{c}{ Title } \\
\hline $\begin{array}{l}\text { Alberta Energy and Natural } \\
\text { Resources. }\end{array}$ & 1985 & $\begin{array}{l}\text { Developing wildlife habitat by planting trees and shru } \\
\text { Habitat development fact sheet. }\end{array}$ \\
Anderson, E. and Scherzinger, R.J. 1975 & $\begin{array}{l}\text { Improving quality of winter forage for elk by cattle } \\
\text { grazing. }\end{array}$ \\
Anderson, W.J. and Markham, B.J. 1981 & $\begin{array}{l}\text { Integrated reclamation for wildlife and agriculture: a } \\
\text { literature review. }\end{array}$
\end{tabular}

Anonymous.

Barrett, M.W.

Bentz, J.A

Brechtel, S. and Culbert, D.

David Walker and Associates Ltd.

Deering, P. and Olson, W.

Drew, M.L. and Samuel, W.M.

Eccles, T.R., Salter, R.E. and Green, J.E.

Ewaschuk, E. and Westworth, D.A. 1983

Fothergill, P. and Greenfield, B.

Green, J.E. and Harrison, G.

Green, J.E. and Salter, R.E.

Green, J.E. and Salter, R.E.

Green, J.E., Salter, R.E. and

Fooks, C.E.

Green, J.E., Salter, R.E. and Walker, D.

Gudmundson, L. and Russell, L.

Jalkotzy, M.

Johnston, A., Smoliak, S., Smith, 1967 A.D. and Lutwick, L.E.

Lungle, K.J.
1986

1979

1981

1977

1989

1987

Sunkay Creek ungulate range enhancement project completion report.

Evaluation of fertilizer on pronghom winter range in Alberta.

Effects of fire on the subalpine range of Rocky Mountain bighorn sheep in Alberta.

Beaverhill Lake habitat management project progress report 1975 and 1976.

The Athabasca Ranch elk winter range improvement study II.

Ungulate and vegetation management report: Status and recommendations.

An evaluation of burning for control of winter ticks, Dermacentor albipictus, in central Alberta.

1987 Certification criteria for wildlife habitat reclamation in the mountain and foothills biomes of Alberta: technical document.

An evaluation of the Red Deer County habitat retention on private land program.

Bighorn sheep range enhancement for the Mount Allan area.

Applications and costs of wildlife habitat reclamation.

1987 Reclamation of wildlife habitat in the Canadian prairie provinces. Vol. 1: techniques for the creation and enhancement of wildlife habitat.

1986 Reclamation of wildlife habitat in the mountain and foothill biomes of Alberta. Vol. 1: reclamation techniques and habitat requirements.

Requirements for the maintenance of moose range in the foothills area of southern Alberta.

Elk and Bighorn sheep winter range clearing opportunities in the Highwood River drainage.

Improvement of southeastern Alberta range with fertilizers.

Selected bibliography on literature related to big game habitat: development, measurement and management.
Journal / Conference / Etc.

E.N.R. Report No. 1/121-No. 2. Edmonton.

Journal of Range Management, 28, 120-125.

Prepared for the Reclamation Research Technical Advisory Committee, prepared by Alberta Fish and Wildlife Division, Edmonton. Unpublished report.

Alberta Fish and Wildlife Division, Edmonton. Unpublished report.

Journal of Range Management, 32, 55-59.

M.Sc. Thesis. University of Alberta, Edmonton.

Alberta Fish and Wildlife Division, Edmonton. Unpublished report.

Alberta Fish and Wildlife Division, Edmonton. Unpublished report.

Elk Island National Park. Unpublished report.

Journal of Wildlife Disease, 21, 313-315.

Prepared for The Mountain Foothills Reclamation Research Program of Alberta Energy and Natural Resources and The Coal Association of Canada. Edmonton. Unpublished report.

Prepared by Westworth, D.A. and Associates Ltd., prepared for Alberta Fish and Wildlife Division, Edmonton. Unpublished report.

Alberta Fish and Wildlife Division, Calgary. Unpublished Report.

pp. 55-74. In: C.B. Powter, R.J. Fessenden and D.G. Walker (eds). Proceedings of the 1985 and 1986 Alberta Reclamation Conferences. Alberta

Chapter, Canadian Land Reclamation Association.

Prepared for Environment Canada and the Alberta Recreation, Parks and Wildlife Foundation; prepared by The Delta Environmental Management Group Ltd., Calgary.

Prepared for Environment Canada and the Alberta Recreation, Parks and Wildlife Foundation; prepared by the Delta Environment Management Group Ltd., Calgary.

The Delta Environment Management Group Ltd., Calgary; prepared for Recreation, Parks and Wildlife Foundation and Environment Canada.

Prepared for the Land Conservation and Reclamation Council and The Coal Association of Canada, prepared by the Delta Environmental Management Group Ltd., Alberta Land Conservation and Reclamation Council Report.

Alberta Fish and Wildlife Division, Edmonton. Unpublished report.

Alberta Fish and Wildlife Division, Edmonton. Unpublished report.

Canadian Journal of Plant Science, 47, 671-678.

Alberta Fish and Wildlife Division, Edmonton. Unpublished report. 


\begin{tabular}{|c|c|c|}
\hline Author(s) / Editor & Date & Title \\
\hline MacCallum, B. & 1983 & $\begin{array}{l}\text { Habitat resource and range improvement in the Alberta } \\
\text { foothills, south of the Bow River. }\end{array}$ \\
\hline Markham, B. & 1977 & Habitat retention on private lands. \\
\hline Markham, B.J. and Forster, P. & 1974 & $\begin{array}{l}\text { The Moose Creek habitat improvement project. "Buck for } \\
\text { Wildlife" project No. W-08-73. }\end{array}$ \\
\hline McFarland, I.M. & 1983 & Wildlife habitat retention on private agricultural land. \\
\hline Morgantini, L.E. & 1991 & $\begin{array}{l}\text { Elk habitat improvement through timber harvesting in west } \\
\text { central Alberta. }\end{array}$ \\
\hline
\end{tabular}

Morgantini, L.E., Eslinger, D. and 1989 Woodard, P.M.

Natural Resources Information Service (NRIS).

Neave, D.J. and Parlby, G.B.

Nietfeld, M.T., Wilk, J., and

Woolnough, K.

Olson, W. Forest, S. and Sissons A.

Poston, H.J. and Schmidt, R.R.

Prism Environmental Management 1984 Consultants Ltd.

Salter, R.E., Eccles, T.R. and Green, J.E.

Telfer, E.S.

Telfer, E.S. and Dauphine, T.C.

Usher, $\mathbf{R}$.

Walker and Associates Ltd.

Watson, L.E, Parker, R.W. and Polster, D.F.

Westworth, D.A. and Associates Ltd.

Westworth, D.A., Brusnyk, L.M. 1984 and Burns, G.R.

Wingert, K. and Culbert, D.

Wiseley, A.N.

1980

Elk habitat improvement through timber harvesting in west-central Alberta.

Ungulate and vegetation management report: Status and recommendations.

Wildlife habitat. A handbook for Canada's prairies and parklands.

Habitat enhancement and the petroleum industry.

987 Certification criteria for wildlife habitat reclamation in mountain and foothills biomes of Alberta: assessment handbook.

Recommendations for wildlife habitat management on the Kananaskis research forest.

Problems facing wildlife habitat management on Canadian forest lands.

The response of moose and woody browse to clearing in the boreal mixed-wood zone of Alberta.

The Athabasca Ranch elk winter range improvement study.

1980 Manual of plant species suitability for reclamation in Alberta.

1983 A moose habitat improvement program for the Livingstone-Porcupine areas of southwestem Alberta. Volume II.

Impact on wildlife of short-rotation management of boreal aspen stands.

The Lychak habitat improvement project progress report 1974-75.

Habitat management and manipulation for wildlife in
Journal / Conference / Etc.

Alberta Fish and Wildlife Division, Edmonton. Unpublished report.

In: Proceedings of 1977 Prairie Wildlife Habitat Conference. Brooks, April 2-4, 1977.

Alberta Fish and Wildlife Division, Edmonton. Unpublished report.

Masters of Environmental Design Project. University of Calgary, Calgary.

Abstract from Alberta Chapter of the Wildlife Society, 2nd Annual meeting. March 23 and 24, 1991, Edmonton.

pp. 170-176. In: Proceedings of the Westem States and Provinces Elk Workshop. Wenatchee, WA.

Alberta Energy and Natural Resources Technical Report, Edmonton. Unpublished report.

Alberta Fish and Wildlife Division, Edmonton. Unpublished report

Fish and Wildlife Division, Wildlife Resource Inventory Unit, Edmonton. Tech. Rep. No. $\mathrm{T} / 73.260 \mathrm{pp}$.

Elk Island National Park. Unpublished report. Kananaskis Country: strategies and methodology.
Canadian Wildlife Service, Edmonton. Unpublished report

A final report submitted to the Canadian Petroleum Association and Alberta Fish and Wildlife Division Edmonton.

Prepared for The Mountain Foothills Reclamation Research Program of Alberta Energy and Natural Resources and The Coal Association of Canada. Edmonton. Unpublished report.

Canadian Wildlife Service, Edmonton. Unpublished report.

Transaction of North American Wildlife and Natural Resources Conference, 46, 368.

M.Sc. Thesis. University of Calgary, Calgary.

Prepared for Alberta Fish and Wildlife Division, Edmonton. Unpublished report.

Alberta Land Conservation Reclamation Council. Report RRTAC 80-5. 2 vols.

Prepared for Alberta Fish and Wildlife Division,

Prepared for Canadian Forestry Service (Enfor Project No. P-203), Edmonton. Unpublished report.

Alberta Fish and Wildlife Division, Edmonton. Unpublished report.

Planning document \#7, Alberta Fish and Wildlife Division, Edmonton. Unpublished report. Edmonton. Unpublished report. 


\begin{tabular}{|c|c|c|}
\hline Author(s) / Editor & Date & Title \\
\hline Allen, J.R. & 1985 & Elk trapping field operations, 1984/85. \\
\hline $\begin{array}{l}\text { Armstrong, G.G. and Dickinson, } \\
\text { D. }\end{array}$ & 1969 & $\begin{array}{l}\text { Herd reduction of moose populations in Cypress Hills } \\
\text { Provincial Park. }\end{array}$ \\
\hline Bjorn, A.R. & 1982 & Elk trapping summary, Elk Island National Park, 1982 \\
\hline Blood, D.A. & 1972 & Removal of surplus ungulates, western national parks. \\
\hline Blyth, C. & 1981 & $\begin{array}{l}\text { Moose reduction program - Elk Island National Park, } \\
1980 .\end{array}$ \\
\hline Blyth, C. and Willman, J. & 1981 & $\begin{array}{l}\text { Elk and moose live capture, Elk Island National Park, } \\
\text { winter } 1981 .\end{array}$ \\
\hline Cool, N.L. & 1983 & Elk trapping summary. Elk Island National Park. \\
\hline Cool, N.L. & 1985 & $\begin{array}{l}\text { Terms of reference for an alternate method of moose } \\
\text { population reduction. }\end{array}$ \\
\hline
\end{tabular}

Didrikson, R. and Wishart, W.

Elk Island National Park:

Fuller, W.A.

Fuller, W.A.

Fuller, W.A.

Fuller, W.A.

Fuller, W.A.

Fuller, W.A.

Jasper National Park.

Jones, V.R.

Jowelt, P.

Kjorlien, M.E.

Mair, W.W.

Mitchell, W.K.

Novakowski, N.S.

1965

Novakowski, N.S. and Choquette, 1964 L.P.E.

Olson, B.E.

Olson, B.E.

Olson, B.E.
Summary of elk handled during the 1976-1977 winter elk trapping and transplant program at Elk Island National Park.

Report of buffalo slaughter.

Hunting wood buffalo.

Special report on the buffalo hunt, 1950-51.

Report on the buffalo hunt, Wood Buffalo Park, January 16 - February 10, 1952.

Report on the buffalo hunt, Wood Buffalo Park, November 24 to December 13, 1952.

Report on the buffalo
Park, January, 1954.

Report on the buffalo slaughter, Wood Buffalo National Park, January 5-20, 1956.

Elk reduction program - Jasper National Park.

Plains bison reduction program - 1971.

1988-89 trapping report.

A report on live trapping elk and moose, 1969.

Elk reduction, Banff National Park.

Report on the elk slaughter, 1946-47.

Slaughter report - Grande Detour, 1964-65.

Slaughter report - Hay Camp, Wood Buffalo National Park, November 1964.

Wood Buffalo National Park buffalo round-up - testing and slaughter programme, 1958.

Wood Buffalo National Park buffalo round-up - testing and slaughter programme, 1959.

Wood Buffalo National Park buffalo round-up - testing and slaughter programme, 1961.

Field kill - 1962, Wood Buffalo National Park.
Journal / Conference / Etc.

Alberta Fish and Wildlife Division, Edmonton. Unpublished report.

Alberta Fish and Wildlife Division, Edmonton. Unpublished report.

Elk Island National Park. Parks Canada, Calgary. Unpublished report.

Canadian Wildlife Service, Edmonton. Unpublished report.

Parks Canada, Calgary. Unpublished report.

Elk Island National Park. Parks Canada, Calgary. Unpublished report.

Elk Island National Park. Parks Canada, Calgary. Unpublished report.

Parks Canada, Calgary. Unpublished report.

Alberta Fish and Wildlife Division, Edmonton. Unpublished report.

Parks Canada, Calgary. Unpublished report.

Blue Jay, 6, 6-7.

Canadian Wildlife Service, Edmonton. Unpublished report.

Canadian Wildlife Service, Edmonton. Unpublished report.

Canadian Wildlife Service, Edmonton. Unpublished report.

Canadian Wildlife Service, Edmonton. Unpublished report.

Canadian Wildlife Service, Edmonton. Unpublished report.

Parks Canada, Calgary. Unpublished report.

Elk Island National Park, Parks Canada, Calgary. Unpublished report.

Elk Island National Park. Unpublished report.

Elk Island National Park, Parks Canada, Calgary. Unpublished report.

Canadian Wildlife Service, Edmonton. Unpublished report.

Canada Parks Service.

Canadian Wildlife Service, Edmonton. Unpublished report.

Canadian Wildlife Service, Edmonton. Unpublished report.

Northem Administration Branch, Department of Northem Affairs and National Resources, Ottawa, ON.

Northern Administration Branch, Department of Northern Affairs and National Resources, Ottawa, ON.

Northern Administration Branch, Department of Northern Affairs and National Resources, Ottawa, ON.

Northern Administration Branch, Department of Northern Affairs and National Resources, Ottawa, ON. 
Herd Reductions

\begin{tabular}{|c|c|c|c|}
\hline Author(s) / Editor & Date & Title & Journal / Conference / Etc. \\
\hline Robsertson, J.R. & 1970 & Elk reduction program report. & $\begin{array}{l}\text { Banff National Park, Parks Canada, Calgary. } \\
\text { Unpublished report. }\end{array}$ \\
\hline Ross, T.A. & 1969 & $\begin{array}{l}\text { Proposed elk slaughter, 1969-1970, Waterton Lakes } \\
\text { National Park. }\end{array}$ & Parks Canada, Calgary. Unpublished report. \\
\hline Stenton, J.E. & 1960 & $\begin{array}{l}\text { Series of master tables for elk slaughters, Banff National } \\
\text { Park. }\end{array}$ & Parks Canada, Calgary. Unpublished report. \\
\hline Van Dyke, D. & 1957 & Report of buffalo slaughter, 1957. & $\begin{array}{l}\text { Northern Administration Branch, Department of } \\
\text { Northern Affairs and National Resources, Ottawa, } \\
\text { ON. }\end{array}$ \\
\hline Winkler, L. & 1988 & 1987-88 Elk trapping report. & Elk Island National Park. Unpublished report. \\
\hline Young, N.A. & 1970 & Report on 1969-70 elk reduction program. & $\begin{array}{l}\text { Jasper National Park, Parks Canada, Calgary. } \\
\text { Unpublished report. }\end{array}$ \\
\hline
\end{tabular}




\begin{tabular}{|c|c|c|}
\hline Author(s) / Editor & Date & Title \\
\hline Alberta Fish and Game Association. & 1986 & $\begin{array}{l}\text { Alberta wildlife trophies. Official records of the Alberta } \\
\text { Fish and Game Association. }\end{array}$ \\
\hline Anonymous. & 1985 & Hunter training conservation manual. \\
\hline Anonymous. & 1986 & 1985-86 Alberta licensed guides and outfitters. \\
\hline Anonymous. & 1986 & $\begin{array}{l}\text { Harvest and effort by resident big game and game bird } \\
\text { hunters in } 1985 \text {. Final edition. }\end{array}$ \\
\hline Anonymous. & 1987 & Alberta hunting guide. \\
\hline Anonymous. & 1987 & $\begin{array}{l}\text { Alberta resident harvest of moose, elk, white-tailed deer } \\
\text { and mule deer in } 1984 \text {. }\end{array}$ \\
\hline Arbuckle, R. & 1984 & $\begin{array}{l}\text { Compulsory elk registration summary, Peace River regio } \\
25 \text { February, } 1985 \text {. }\end{array}$ \\
\hline Armstrong, G.G. & 1966 & Foothills and subalpine big game harvest. \\
\hline Armstrong, G.G. & 1966 & Prairie deer harvests, 1966. \\
\hline Armstrong, G.G. & 1966 & Results of big game season. \\
\hline Armstrong, G.G. & 1969 & $\begin{array}{l}\text { Season and bag limit recommendations for the Oldman } \\
\text { River elk herd in F } 308 \text { and S } 402 \text {. }\end{array}$ \\
\hline Banfield, A.W.F. & 1951 & Buffalo slaughter, Elk Island National Park, 1946. \\
\hline
\end{tabular}

Barrett, M.W.

1970

Barrett, M.W.

Barrett, M.W.

Barrett, M.W.

Biglin, T.A.

Boone and Crockett Club.

Boone and Crockett Club.

Boone and Crockett Club.

Boone and Crockett Club.

Boone and Crockett Club.

Boone and Crockett Club.

Boone and Crockett Club.

Boone and Crockett Club.

Boone and Crockett Club.

1971 Antelope harvest statistics.

1972 Antelope harvest statistics.

1973 Antelope harvest statistics.

1985 Review of 1985 hunting season Brooks district.

1952 Records of North American big game.

1958 Records of North American big game.

1964 Records of North American big game.

1971 Records of North American big game.

1977 Records of North American big game.

1981 Records of North American big game.

1984 18th big game awards.

1986 19th big game awards.

1987 Records of North American whitetail deer.

Boxall, P.C. and Smith, L.C. 1986 Characteristics of Alberta's hunters 1974-1984.

Boxall, P.C. and Smith, L.C. 1987 Estimation of the illegal harvest of deer in Alberta: a violation simulation study.

Boxall, P.C., Melnyk, M.J. and Cormier, L.
The estimation of illegal activity relating to wildlife in Alberta: a pilot study using violation simulation techniques.
Journal / Conference / Etc.

McIntosh Publishing, North Battleford, SK.

Alberta Energy and Natural Resources, Edmonton.

Alberta Fish and Wildlife Division, Edmonton. Unpublished report.

Alberta Fish and Wildlife Division, Edmonton. Unpublished report.

Annual magazine published by Kevin Rolfe, Edmonton.

Alberta Fish and Wildlife Division, Edmonton. Unpublished report.

Alberta Fish and Wildlife Division, Edmonton. Unpublished report.

Alberta Fish and Wildlife Division, Edmonton. Unpublished report.

Alberta Fish and Wildlife Division, Edmonton. Unpublished report.

Alberta Fish and Wildlife Division, Edmonton Unpublished report.

Alberta Fish and Wildlife Division, Edmonton. Unpublished report.

Canadian Wildlife Service, Edmonton. Unpublished report.

Alberta Fish and Wildlife Division, Edmonton. Unpublished report.

Alberta Fish and Wildlife Division, Edmonton. Unpublished report.

Alberta Fish and Wildlife Division, Edmonton. Unpublished report.

Alberta Fish and Wildlife Division, Edmonton. Unpublished report.

Alberta Fish and Wildlife Division, Edmonton. Unpublished report.

Charles Scribner's Sons, New York, NY.

Henry Holt and Co., New York, NY.

Holt, Reinholt and Winston, New York, NY.

Davis and Warde Inc., Pittsburgh, PA.

Printed by R.R. Donnelley and Sons, Co., Chicago, IL.

Published by Boone and Crockett Club, Alexandria, VA.

Published by Boone and Crockett Club, Alexandria, VA.

Published by Boone and Crockett Club, Alexandria, VA.

Published by Boone and Crockett Club. Dumfreys, VA.

Alta. Fish and Wildlife Div., Edmonton, Occasional Paper Number 1.

Alberta Fish and Wildlife Division, Edmonton Unpublished report.

Alberta Fish and Wildlife Division, Edmonton. Unpublished report. 


\begin{tabular}{|c|c|c|}
\hline Author(s) / Editor & Date & Title \\
\hline Carr, H. & 1979 & A discussion paper on hunting in Kananaskis Country. \\
\hline Erickson, G. & 1970 & $\begin{array}{l}\text { The influence of snowmobiles on deer hunting success in } \\
\text { Camp Wainwright. }\end{array}$ \\
\hline Ewanyk, L.J. & 1976 & $\begin{array}{l}\text { Hunter - land owner relations in east central Alberta: a } \\
\text { socioeconomic study of a property rights conflict. }\end{array}$ \\
\hline Festa-Bianchet, M. & 1986 & Bighorn ram survival and harvest in southwestern Alberta. \\
\hline Folinsbee, J. & 1985 & $\begin{array}{l}\text { Camp Wainwright deer season } 28 \text { November- } 14 \\
\text { December, } 1985 \text { data summary. }\end{array}$ \\
\hline Folinsbee, J. & 1985 & $\begin{array}{l}\text { Strathcona county quota hunt for white-tailed deer. } \\
\text { December } 1984 \text { - January } 1985 \text {. }\end{array}$ \\
\hline Folinsbee, J. & 1986 & $\begin{array}{l}\text { Camp Wainwright deer season } 28 \text { Nov.-14 December, } \\
1985 \text { data summary. }\end{array}$ \\
\hline Folinsbee, J. & 1986 & Strathcona county quota deer hunt; Dec. 1985 - Jan. 1986. \\
\hline Folinsbee, J. & 1987 & $\begin{array}{l}\text { Camp Wainwright deer season ( } 26 \text { Nov. - } 12 \text { Dec., } \\
\text { 1987). Data summary. }\end{array}$ \\
\hline Folinsbee, J. & 1987 & $\begin{array}{l}\text { Camp Wainwright deer season, } 27 \text { November - } 13 \\
\text { December, 1986, data summary. }\end{array}$ \\
\hline Folinsbee, J. & 1989 & $\begin{array}{l}\text { Camp Wainwright deer season, } 23 \text { November - } 9 \\
\text { December } 1989 \text { data summary. }\end{array}$ \\
\hline Folinsbee, J. & 1989 & $\begin{array}{l}\text { Camp Wainwright deer season, Nov. } 24 \text { - Dec. 10, } 1988 \\
\text { data summary. }\end{array}$ \\
\hline Folinsbee, J. & 1990 & $\begin{array}{l}\text { Camp Wainwright deer season, } 29 \text { November - } 15 \\
\text { December 1990, data summary. }\end{array}$ \\
\hline Fraser, $\mathrm{P}$. & 1982 & $\begin{array}{l}\text { Big game hunting statistics for the eastern slopes region } \\
\text { south of the Bow. Final report Jan. 22, } 1982 \text {. }\end{array}$ \\
\hline Fullerton, $\mathbf{L}$. & 1987 & The decline of a species; the Alberta hunter. \\
\hline Gudmundson, L. & 1987 & $\begin{array}{l}\text { Report on male Mule deer authorization program } \\
\text { introduced in big game zone } 8 \text { in } 1980 \text {. }\end{array}$ \\
\hline Gunderson, G. & 1986 & $\begin{array}{l}\text { Camp Wainwright post hunting season deer survey } \\
\text { December } 15,1986 .\end{array}$ \\
\hline Gunderson, G. and Rippin, B. & 1977 & $\begin{array}{l}\text { Special permit moose hunt Long Lake area, Nov. 29-Dec. } \\
11,1976 .\end{array}$ \\
\hline Gunderson, G. and Rippin, B. & 1978 & $\begin{array}{l}\text { Special permit moose hunt Long Lake area (Nov. 28-Dec. } \\
10,1977 \text { ). }\end{array}$ \\
\hline Hall, B. and Cook, A. & 1974 & Documentation of the 1973 non-trophy sheep season. \\
\hline
\end{tabular}

Hall, B., Gunderson, G., Cook, A. 1974 Documentation of the 1973 mountain goat season. and Bibaud, A.

Hofman, D.

Holton, G.R.

1986 Summary of compulsory registration of elk in the Peace River region, 1985.

Jamieson, F.C.

1953 The Edmonton hunt.

Jamieson, F.C.

1969 The Edmonton hunt.

Kemp, G.

1965

Kerr, G.R.

1966

Big game harvest from Entrance checking station during fall, 1965.

Lynch, G.M.
Journal / Conference / Etc.

Alberta Fish and Wildlife Division, Edmonton Unpublished report.

Alberta Fish and Wildlife Division, Edmonton. Unpublished report.

M.Sc. Thesis. University of Alberta, Edmonton.

Proceedings of the Northern Wild Sheep and Goat Council, 5, 102-109.

Alberta Fish and Wildlife Division, Edmonton. Unpublished report.

Alberta Fish and Wildlife Division, Edmonton. Unpublished report.

Alberta Fish and Wildlife Division, Edmonton. Unpublished report.

Alberta Fish and Wildlife Division, Edmonton. Unpublished report.

Alberta Fish and Wildlife Division, Edmonton. Unpublished report.

Alberta Fish and Wildlife Division, Edmonton. Unpublished report.

Alberta Fish and Wildlife Division, Edmonton. Unpublished report.

Alberta Fish and Wildlife Division, Edmonton. Unpublished report.

Alberta Fish and Wildlife Division, Edmonton. Unpublished report.

Alberta Fish and Wildlife Division, Calgary. Unpublished Report.

pp. 29-31. In: Alberta hunting guide. Edmonton.

Alberta Fish and Wildlife Division, Edmonton. Unpublished report.

Alberta Fish and Wildlife Division, Edmonton. Unpublished report.

Alberta Fish and Wildlife Division, Edmonton. Unpublished report.

Alberta Fish and Wildlife Division, Edmonton. Unpublished report.

Alberta Fish and Wildlife Division, Edmonton. Unpublished report.

Alberta Fish and Wildlife Division, Edmonton. Unpublished report.

Alberta Fish and Wildlife Division, Edmonton. Unpublished report.

Alberta Fish and Wildlife Division, Edmonton. Unpublished report.

Alberta Historical Review, 1.

pp. 10-18. In: Pioneer west. Historical Society of Alberta, Calgary.

Alberta Fish and Wildlife Division, Edmonton. Unpublished report.

Alberta Fish and Wildlife Division, Edmonton. Unpublished report.

Alberta Fish and Wildlife Division, Edmonton. Unpublished report. 


\begin{tabular}{|c|c|c|}
\hline Author(s) / Editor & Date & Title \\
\hline Lynch, G.M. & 1972 & $\begin{array}{l}\text { Interim report on the influence of hunting on populations } \\
\text { of Swan Hills moose. }\end{array}$ \\
\hline Lynch, G.M. & 1972 & Quality hunting for ' 72. \\
\hline Lynch, G.M. & 1973 & Hunting synopsis. \\
\hline Lynch, G.M. & 1973 & Influence of hunting on an Alberta moose herd. \\
\hline Lynch, G.M. and Carr, H.D. & 1974 & $\begin{array}{l}\text { Compulsory registration of big game kills in North } \\
\text { America. }\end{array}$ \\
\hline Lynch, G.M. and Carr, H.D. & 1974 & $\begin{array}{l}\text { North American methods of obtaining big game kill data } \\
\text { with special reference to compulsory registration. }\end{array}$ \\
\hline Melnyk, M.J. & 1977 & $\begin{array}{l}\text { Hunter attitudes toward Alberta's wildlife laws and } \\
\text { wildlife officers. }\end{array}$ \\
\hline
\end{tabular}

Mitchell, G.J.

1955 Report on the 1955 big game harvest in southern Alberta.

Mitchell, G.J.

1955 Report on the elk harvest in the Castle District, Crowsnest Forest Reserve.

Mitchell, G.J.

1956 Report on the analysis of the 1953 big game check forms.

Mitchell, G.J.

1957 The big game harvest in the lower Bow-Crowsnest study area, 1956.

Mitchell, G.J.

1958 The 1958 big game harvest zones 1-7 inclusive.

Neave, D.

1967 Bird game and big game populations and harvests - district III. Summary, 1967.

Neave, D.

1968 Bird game and big game populations and harvests - district III. Summary, 1968.

Neave, D.

1969 Bird game and big game populations and harvests - district III. Summary, 1968-69.

Neave, D. and Paulsen, A.

1970 The results of a late elk season on the Corners (S416) and Ya-Ha-Tinda (S418) area in 1970.

Neave, D. and Paulsen, A.

1971 An evaluation of the late winter elk season in 1971 in relation to the 1969 and 1970 season and snowmobile regulations.

Novak, $\mathbf{M}$.

1966 Big game checking station results in 1966, in district V.

Novak, $M$.

1969 The 1968 hunting season in north-east Alberta.

Olson, J.

Ondrack, J.

Pattison, W.S.

1985 Big game hunting in Alberta.

1973 A study of public hunting on private land.

Pattison, W.S.

1973 We raise 'em - you shoot 'em: a study of public hunting on private land.

Paulsen, A. and Nieman, G.

1976 The late season elk hunt in WMU's S416 and S418, Ya-Ha-Tinda.

Paulsen, A.C.

1975 Report on the late season elk hunt in WMU's S416 and S418 - Ya-Ha-Tinda.

President, P.J.A.

1962 Sheep and goat hunter questionnaire retums, 1962.

PRISM.

1981 Wildlife and hunting. A supply/demand assessment of the South Saskatchewan River basin.
Journal / Conference / Etc.

Alberta Fish and Wildlife Division, Edmonton. Unpublished report.

Alberta Sportsman, Vol. 7, No. 5.

Alberta Sportsman, Vol. 8, No. 5.

Proceedings of North American Moose Conference and Workshop, 11, 123-135.

Wildlife Research Series Number 1, Alberta and Wildlife Division, Edmonton

Alberta Fish and Wildlife Division, Edmonton. Unpublished report.

A report brief submitted to the Field

Services-Enforcement. Alberta Fish and Wildlife Division, Edmonton. Unpublished report.

Alberta Fish and Wildlife Division, Edmonton. Unpublished report.

Alberta Fish and Wildlife Division, Edmonton. Unpublished report.

Alberta Fish and Wildlife Division, Edmonton. Unpublished report.

Alberta Fish and Wildlife Division, Edmonton. Unpublished report.

Alberta Fish and Wildlife Division, Edmonton. Unpublished report.

Alberta Fish and Wildlife Division, Edmonton. Unpublished report.

Alberta Fish and Wildlife Division, Edmonton. Unpublished report.

Alberta Fish and Wildlife Division, Edmonton. Unpublished report.

Alberta Fish and Wildlife Division, Edmonton. Unpublished report.

Alberta Fish and Wildlife Division, Edmonton. Unpublished report.

Alberta Fish and Wildlife Division, Edmonton. Unpublished report.

Alberta Fish and Wildlife Division, Edmonton. Unpublished report.

Alberta Fish and Wildlife Division, Edmonton. Unpublished report.

Wildlife Publishing Ltd., Edmonton.

Alberta Agriculture Resource Economics Branch, Edmonton.

Alberta Department of Agriculture, Edmonton.

Alberta Fish and Wildlife Division, Edmonton. Unpublished report.

Alberta Fish and Wildlife Division, Edmonton. Unpublished report.

Alberta Fish and Wildlife Division, Edmonton. Unpublished report.

Prepared by PRISM Environmental Management Consultants, prepared for Alberta Fish and Wildlife Division, Edmonton. Unpublished report. 


\begin{tabular}{lcl}
\hline \multicolumn{1}{c}{ Author(s) / Editor } & Date & Title \\
\hline $\begin{array}{l}\text { Quaedvlieg, M.T., Gunderson, G. } \\
\text { and Cook, A. }\end{array}$ & 1973 & Documentation of the 1972 mountain goat permit season. \\
$\begin{array}{l}\text { Quaedvlieg, M.T., Gunderson, G. } \\
\text { and Cook, A. }\end{array}$ & 1973 & Documentation of the non-trophy sheep season. \\
$\begin{array}{l}\text { Ritcey, R.W. } \\
\text { Schneider, M.E. }\end{array}$ & 1974 & Moose harvesting programs in Canada. \\
& 1983 & $\begin{array}{l}\text { A summary of big game harvest statistics for species under } \\
\text { authorization. }\end{array}$
\end{tabular}

Schurman, S.

1976 Antelope harvest statistics, 1975.

Schurman, S.

1977 Documentation of the 1977 non-trophy sheep season.

Schurman, S.

1978 Antelope harvest statistics, 1977.

Schurman, S.

1978 Antlerless mule deer harvest statistics. 1977.

Schurman, S.

Schurman, S.

Schurman, S.

Schurman, S.

Schurman, S. and Hall, B.

Schurman, S. and Hall, B.

Schurman, S. and Hall, B.

Schurman, S. and Hall, B.

Schurman, S. and Hall, B.

Seal, C.M.

Smith, K.G.

Smith, K.G. and Wishart, W.D

Smith, S.B.

Stelfox, J.G.

Stelfox, J.G.

Stelfox, J.G.

Stelfox, J.G.

Stelfox, J.G.

Stelfox, J.G.
1979 Antelope harvest statistics, 1978.

1979 Antlerless mule deer harvest statistics, 1978.

1979 Antlerless white-tailed deer harvest statistics - 1978

1979 Results from the 1978 elk season.

1976 Antlerless white-tailed deer harvest statistics - 1976.

1976 Documentation of the 1975 non-trophy sheep season.

1977 Antelope harvest statistics 1976.

1977 Antlerless mule deer harvest statistics, 1977.

1977 Antlerless white-tailed deer harvest statistics - 1977.

1952 Report on the annual buffalo kill, Wood Buffalo Park, N.W.T.

1982 Elk harvest in the Edson east slopes region 1975-82.

1978 Further observations of bighom sheep non-trophy seasons in Alberta and their management implications.

Non-resident moose hunting in Alberta-1967.

1955 A report of the proposed big game checking stations in the Edson and Whitecourt Forestry Division for 1956.

1955 Results of the big game hunting season for 1955 in the following areas: A. Athabasca forest reserve, B., Coalbranch district, C., Entwistle to Jasper Park.

1956 Big game harvest in the Brazeau, Pembina, McLeod, Athabasca, Smoky River watersheds, October 15 -

1956 Big game harvest in the Coalbranch area October 15 November 30, 1956.

1956 Big game hunting in the Grande Prairie region. October 30, 1956.
Journal / Conference / Etc.

Alberta Fish and Wildlife Division, Edmonton. Unpublished report.

Alberta Fish and Wildlife Division, Edmonton. Unpublished report.

Naturaliste Canadien, 101, 631-642.

Alberta Fish and Wildlife Division, Edmonton. Unpublished report.

Alberta Fish and Wildlife Division, Edmonton. Unpublished report.

Alberta Fish and Wildlife Division, Edmonton. Unpublished report.

Alberta Fish and Wildlife Division, Edmonton. Unpublished report.

Alberta Fish and Wildlife Division, Edmonton. Unpublished report.

Alberta Fish and Wildlife Division, Edmonton. Unpublished report.

Alberta Fish and Wildlife Division, Edmonton. Unpublished report.

Alberta Fish and Wildlife Division, Edmonton. Unpublished report.

Alberta Fish and Wildlife Division, Edmonton Unpublished report.

Alberta Fish and Wildlife Division, Edmonton. Unpublished report.

Alberta Fish and Wildlife Division, Edmonton. Unpublished report.

Alberta Fish and Wildlife Division, Edmonton. Unpublished report.

Alberta Fish and Wildlife Division, Edmonton. Unpublished report.

Alberta Fish and Wildlife Division, Edmonton. Unpublished report.

Canada Department of Agriculture, Ottawa, ON. Unpublished report.

Alberta Fish and Wildlife Division, Edmonton. Unpublished report.

pp. 52-74. In: Proceedings of Biennial Symposium of the Northern Wild Sheep and Goat Council. Penticton, BC.

Alberta, Land-Forest-Parks Wildlife, 11, 34-38.

Alberta Fish and Wildlife Division, Edmonton. Unpublished report.

Alberta Fish and Wildlife Division, Edmonton. Unpublished report.

Alberta Fish and Wildlife Division, Edmonton. Unpublished report.

Alberta Fish and Wildlife Division, Edmonton. Unpublished report.

Alberta Fish and Wildlife Division, Edmonton. Unpublished report.

Alberta Fish and Wildlife Division, Edmonton. Unpublished report. 


\begin{tabular}{|c|c|c|c|}
\hline Author(s) / Editor & Date & Title & Journal / Conference / Etc. \\
\hline Stelfox, J.G. & 1956 & Recommendations for big game season, 1956. & $\begin{array}{l}\text { Alberta Fish and Wildlife Division, Edmonton. } \\
\text { Unpublished report. }\end{array}$ \\
\hline Stelfox, J.G. & 1962 & $\begin{array}{l}\text { Big game harvests in } 1962 \text { in zones } 12,13,14,15,16 \text { and } \\
18 \text {. }\end{array}$ & $\begin{array}{l}\text { Alberta Fish and Wildlife Division, Edmonton. } \\
\text { Unpublished report. }\end{array}$ \\
\hline Stelfox, J.G. & 1963 & $\begin{array}{l}\text { Big game harvests in northwestern Alberta during early fall } \\
\text { season. }\end{array}$ & $\begin{array}{l}\text { Alberta Fish and Wildlife Division, Edmonton. } \\
\text { Unpublished report. }\end{array}$ \\
\hline Stelfox, J.G. & 1964 & Big game harvests in northwestem Alberta. & $\begin{array}{l}\text { Alberta Fish and Wildlife Division, Edmonton. } \\
\text { Unpublished report. }\end{array}$ \\
\hline Stelfox, J.G. & 1964 & $\begin{array}{l}\text { Mountain big game trophy harvests and measurements of } \\
\text { bighorn, Rocky Mountain goat, caribou and bear in N.W. } \\
\text { Alberta. }\end{array}$ & $\begin{array}{l}\text { Alberta Fish and Wildlife Division, Edmonton. } \\
\text { Unpublished report. }\end{array}$ \\
\hline Stelfox, J.G. & 1965 & $\begin{array}{l}1965 \text { big game populations and harvests in northwestern } \\
\text { Alberta. }\end{array}$ & $\begin{array}{l}\text { Alberta Fish and Wildlife Division, Edmonton. } \\
\text { Unpublished report. }\end{array}$ \\
\hline Stelfox, J.G. & 1965 & $\begin{array}{l}\text { Mountain big game trophy harvests and measurements in } \\
\text { N.W. Alberta for } 1965 \text { of bighoms, Rocky Mountain } \\
\text { goats, caribou, bear and cougar. }\end{array}$ & $\begin{array}{l}\text { Alberta Fish and Wildlife Division, Edmonton. } \\
\text { Unpublished report. }\end{array}$ \\
\hline Stelfox, J.G. & 1965 & Trophy hunting in Alberta. & Land, Forest, Wildlife, 8, 3-8. \\
\hline Stelfox, J.G. & 1966 & Alberta trophy hunting. & Information Bulletin, No. 4. \\
\hline Stelfox, J.G. & 1966 & $\begin{array}{l}\text { Bighorn and Rocky Mountain goat populations, } \\
\text { reproductions, harvests and proposed } 1966 \text { seasons. }\end{array}$ & $\begin{array}{l}\text { Alberta Fish and Wildlife Division, Edmonton. } \\
\text { Unpublished report. }\end{array}$ \\
\hline Stelfox, J.G. & 1966 & $\begin{array}{l}\text { Deer and elk populations, harvests, range conditions and } \\
\text { proposed } 1966 \text { season. }\end{array}$ & $\begin{array}{l}\text { Alberta Fish and Wildlife Division, Edmonton. } \\
\text { Unpublished report. }\end{array}$ \\
\hline Stelfox, J.G. & 1966 & $\begin{array}{l}\text { Moose populations, harvests, range conditions and } \\
\text { proposed } 1966 \text { seasons. }\end{array}$ & $\begin{array}{l}\text { Alberta Fish and Wildlife Division, Edmonton. } \\
\text { Unpublished report. }\end{array}$ \\
\hline Stelfox, J.G. and Kemp, G. & 1965 & $\begin{array}{l}\text { Big game harvests in northwestern Alberta during fall } \\
1965 .\end{array}$ & $\begin{array}{l}\text { Alberta Fish and Wildlife Division, Edmonton. } \\
\text { Unpublished report. }\end{array}$ \\
\hline Taggart. K. and Smith, K. & 1984 & $\begin{array}{l}\text { Elk harvest by compulsory registration in the Edson east } \\
\text { slopes region, } 1975-1983 \text {. }\end{array}$ & $\begin{array}{l}\text { Alberta Fish and Wildlife Division, Edmonton. } \\
\text { Unpublished report. }\end{array}$ \\
\hline Webb, R. & 1955 & $\begin{array}{l}\text { Big game checking station report - Bow-Clearwater study } \\
\text { area. }\end{array}$ & $\begin{array}{l}\text { Alberta Fish and Wildlife Division, Edmonton. } \\
\text { Unpublished report. }\end{array}$ \\
\hline Webb, R. & 1957 & $\begin{array}{l}\text { Big game checking station report - Bow-Clearwater study } \\
\text { area. }\end{array}$ & $\begin{array}{l}\text { Alberta Fish and Wildlife Division, Edmonton. } \\
\text { Unpublished report. }\end{array}$ \\
\hline Webb, R. & 1958 & $\begin{array}{l}\text { Big game checking station report - Bow-Clearwater study } \\
\text { area. }\end{array}$ & $\begin{array}{l}\text { Alberta Fish and Wildlife Division, Edmonton. } \\
\text { Unpublished report. }\end{array}$ \\
\hline Webb, R. & 1958 & $\begin{array}{l}\text { Suggestions for the } 1958 \text { big game season in central } \\
\text { Alberta. }\end{array}$ & $\begin{array}{l}\text { Alberta Fish and Wildlife Division, Edmonton. } \\
\text { Unpublished report. }\end{array}$ \\
\hline Webb, R. & 1959 & $\begin{array}{l}\text { Big game checking station report - Bow-Clearwater study } \\
\text { area. }\end{array}$ & $\begin{array}{l}\text { Alberta Fish and Wildlife Division, Edmonton. } \\
\text { Unpublished report. }\end{array}$ \\
\hline Webb, R. & 1964 & $\begin{array}{l}\text { Establishment of long term hunting seasons for antlered } \\
\text { cervids, sheep, goat and antelope. }\end{array}$ & $\begin{array}{l}\text { Alberta Fish and Wildlife Division, Edmonton. } \\
\text { Unpublished report. }\end{array}$ \\
\hline Webb, R. & 1964 & $\begin{array}{l}\text { Suggestions prairie deer, antelope and antlerless big game } \\
\text { seasons. }\end{array}$ & $\begin{array}{l}\text { Alberta Fish and Wildlife Division, Edmonton. } \\
\text { Unpublished report. }\end{array}$ \\
\hline Webb, R. & 1966 & $\begin{array}{l}\text { Foothills big game sex, age, physical and reproductive } \\
\text { characteristics from hunter harvests. }\end{array}$ & $\begin{array}{l}\text { Alberta Fish and Wildlife Division, Edmonton. } \\
\text { Unpublished report. }\end{array}$ \\
\hline Webb, R. & 1966 & Foothills deer, elk and moose harvest. & $\begin{array}{l}\text { Alberta Fish and Wildlife Division, Edmonton. } \\
\text { Unpublished report. }\end{array}$ \\
\hline Webb, R. & 1966 & $\begin{array}{l}\text { Prairie deer sex, age and physical characteristics from } \\
\text { hunter harvests. }\end{array}$ & $\begin{array}{l}\text { Alberta Fish and Wildlife Division, Edmonton. } \\
\text { Unpublished report. }\end{array}$ \\
\hline Webb, R. & 1966 & $\begin{array}{l}\text { Suggested for the big game seasons and bag limits for } \\
1966 \text { in district I. }\end{array}$ & $\begin{array}{l}\text { Alberta Fish and Wildlife Division, Edmonton. } \\
\text { Unpublished report. }\end{array}$ \\
\hline West, P. & 1984 & $\begin{array}{l}\text { Report to the reciprocal hunting committee on reciprocal } \\
\text { hunting in Canada. }\end{array}$ & $\begin{array}{l}\text { Canadian Wildlife Service, Edmonton. } \\
\text { Unpublished report. }\end{array}$ \\
\hline Wishart, W. & 1958 & $\begin{array}{l}\text { The big game harvest north of the North Saskatchewan } \\
\text { River. }\end{array}$ & $\begin{array}{l}\text { Alberta Fish and Wildlife Division, Edmonton. } \\
\text { Unpublished report. }\end{array}$ \\
\hline Wishart, W. & 1959 & $\begin{array}{l}\text { Hunting pressure and big game harvest north of the North } \\
\text { Saskatchewan River. }\end{array}$ & $\begin{array}{l}\text { Alberta Fish and Wildlife Division, Edmonton. } \\
\text { Unpublished report. }\end{array}$ \\
\hline
\end{tabular}




\begin{tabular}{|c|c|c|c|}
\hline Author(s) / Editor & Date & Title & Journal / Conference / Etc. \\
\hline Wishart, W. & 1960 & $\begin{array}{l}1960 \text { hunting pressure and big game harvests in zones } 15 \text {, } \\
16,17,18,19,20 \text { and } 21 \text {. }\end{array}$ & $\begin{array}{l}\text { Alberta Fish and Wildlife Division, Edmonton. } \\
\text { Unpublished report. }\end{array}$ \\
\hline Wishart, W. & 1966 & Bighom population and harvest survey. & $\begin{array}{l}\text { Alberta Fish and Wildlife Division, Edmonton. } \\
\text { Unpublished report. }\end{array}$ \\
\hline Wishart, W. & 1966 & $\begin{array}{l}\text { Numbers, sex, age and kill data of deer in biological } \\
\text { district 2, 1963-65. }\end{array}$ & $\begin{array}{l}\text { Alberta Fish and Wildlife Division, Edmonton. } \\
\text { Unpublished report. }\end{array}$ \\
\hline Wishart, W. & 1966 & $\begin{array}{l}\text { Numbers, sex, age and kill data of elk in biological district } \\
2,1963-65 \text {. }\end{array}$ & $\begin{array}{l}\text { Alberta Fish and Wildlife Division, Edmonton. } \\
\text { Unpublished report. }\end{array}$ \\
\hline Wishart, W. & 1966 & $\begin{array}{l}\text { Numbers, sex, age and kill data of moose in biological } \\
\text { district } 2,1963-65 \text {. }\end{array}$ & $\begin{array}{l}\text { Alberta Fish and Wildlife Division, Edmonton. } \\
\text { Unpublished report. }\end{array}$ \\
\hline Wishart, W. & 1968 & 1968 antelope kill. & $\begin{array}{l}\text { Alberta Fish and Wildlife Division, Edmonton. } \\
\text { Unpublished report. }\end{array}$ \\
\hline Wishart, W. & 1968 & Non-trophy sheep kill, 1968. & $\begin{array}{l}\text { Alberta Fish and Wildlife Division, Edmonton. } \\
\text { Unpublished report. }\end{array}$ \\
\hline Wishart, W. & 1969 & $\begin{array}{l}\text { Antelope historic review: estimated antelope population } \\
\text { and harvest 1963-1969. }\end{array}$ & $\begin{array}{l}\text { Alberta Fish and Wildlife Division, Edmonton. } \\
\text { Unpublished report. }\end{array}$ \\
\hline Wishart, W. & 1970 & $\begin{array}{l}\text { When and why it is good management to shoot bighom } \\
\text { ewes and lambs. }\end{array}$ & $\begin{array}{l}\text { Alberta Fish and Wildlife Division, Edmonton. } \\
\text { Unpublished report. }\end{array}$ \\
\hline Wishart, W. & 1975 & Non-trophy sheep harvest summary 1966-74. & $\begin{array}{l}\text { Alberta Fish and Wildlife Division, Edmonton. } \\
\text { Unpublished report. }\end{array}$ \\
\hline
\end{tabular}

\section{Wishart, W.}

Wishart, W.

Wishart, W. and Hall, B.

Wishart, W. and Hall, B.

Wishart, W. and Hall, W.K.

Wishart, W.D.

Wishart, W., Erickson, G. and Hilton, $M$.

Wishart, W., Erickson, G. and Hilton, $\mathbf{M}$.

Wishart, W., Erickson, G. and McNeil, C.

Wishart, W., Erickson, G. and McNeil, C.

Young, B.F., Pelchat, B. and Carr, 1971 H.D.
1978 Response to a test on identifying a 4/5 curl from photographs of rams of various ages and horn sizes.

19711971 game harvest in Camp Wainwright.

1973 Summary of game harvests in Camp Wainwright, 1966-72.

1967 Provincial antelope surveys and harvest, 1963-67.

1974 What are the effects of bighorn trophy hunting?

1975 Grouse and deer harvest in Camp Wainwright.

19791978 Camp Wainwright deer season.

19741974 grouse and deer harvest in Camp Wainwright.

1974 Camp Wainwright deer and grouse season.

Antelope hunting access study in antelope management area $\mathrm{E}$. pp. 70-80. In: Proceedings of Biennial Symposium of the Northern Wild Sheep Council. Jackson, WY.

Alberta Fish and Wildlife Division, Edmonton. Unpublished report.

Alberta Fish and Wildlife Division, Edmonton Unpublished report.

Alberta Fish and Wildlife Division, Edmonton Unpublished report.

Alberta Fish and Wildlife Division, Edmonton. Unpublished report.

pp. 40-44. In: Transaction of Northern Wild Sheep Council. Great Fall, MO.

Alberta Fish and Wildlife Division, Edmonton Unpublished report.

Alberta Fish and Wildlife Division, Edmonton Unpublished report.

Alberta Fish and Wildlife Division, Edmonton. Unpublished report.

Alberta Fish and Wildlife Division, Edmonton. Unpublished report.

Alberta Fish and Wildlife Division, Edmonton. Unpublished report. 


\begin{tabular}{|c|c|c|}
\hline Author(s) / Editor & Date & Title \\
\hline Alberta Fish and Wildlife Division & 1989 & Management plan for mule deer in Alberta. \\
\hline Anonymous. & 1977 & A policy for resource management in the eastern slopes. \\
\hline Anonymous. & 1980 & Management plan for ungulate depredations in Alberta. \\
\hline Anonymous. & 1982 & $\begin{array}{l}\text { Area plan concept summary: wood bison area, Elk Island } \\
\text { National Park. }\end{array}$ \\
\hline Anonymous. & 1982 & Fish and wildlife policy for Alberta. \\
\hline Anonymous. & 1983 & Fish and Wildlife position paper on Cypress Hills elk. \\
\hline Anonymous. & 1984 & $\begin{array}{l}\text { Forestry and wildlife management in Canada - a } \\
\text { symposium. }\end{array}$ \\
\hline Anonymous. & 1985 & $\begin{array}{l}\text { Symposium on Fish and Wildlife Management in Alberta: } \\
\text { Current Practice - Future Strategies. }\end{array}$ \\
\hline
\end{tabular}

Anonymous.

1987

Anonymous

1989

Anonymous.

Anonymous

Anonymous

Anonymous

Anonymous

Anonymous.

Anonymous.

Banfield, A.W.F.

Barrett, M.W.

Barrett, M.W. and Vriend, H.G.

Bloomfield, $\mathrm{M}$.

Bloomfield, M. and Sword, M.

Blyth, C.B. and Hudson, R.J.

Bruns, E.

Bruns, E.H.

Calef, G.W.

Carbyn, L.N., Anions, D. and Huisman, D.

Carr, H.D.
1989

1989

Integrated forestry - wildlife - fish resource management approach for the Champion FMA.

Management plan for mule deer in Alberta.

\section{Management plan for mule deer in Alberta}

Management plan for pronghorn antelope in Alberta.

(in Elk management strategy for Alberta.

(in Moose management strategy for Alberta. prep.)

(in

White-tailed deer management strategy for Alberta.

Undated Managing northern Alberta's bighorn sheep.

Undated Managing northern Alberta's moose population.

1951 Management of elk. Waterton Lakes National Parks.

972 A review of problems pertaining to pronghorn antelope in Alberta.

Management implications of the seasonal distribution of pronghoms and land use practices in Alberta.

Closure of the caribou hunting season in Alberta: management of a threatened species.

Draft proposal to designate Alberta's caribou as a threatened species.

A plan for the management of vegetation and ungulates of Elk Island National Park.

Alberta's mule deer management policy.

Recent changes in Alberta's mule deer populations and management.

Status of bison in the N.W.T.

A review of the status of bison in Wood Buffalo National Park.

1985 Elk management plan for the Calgary area.
Journal / Conference / Etc.

Wildlife Management Plan. Series No. 1. 141 pp.

Alberta Energy and Natural Resources.

Edmonton.

Alberta Fish and Wildlife Division, Edmonton. Unpublished report.

Parks Canada, Calgary. Unpublished report.

Alberta Energy and Natural Resources, Fish and Wildlife Division, Edmonton.

Alberta Fish and Wildlife Division, Edmonton Unpublished report.

University of British Columbia, Vancouver, BC

Sponsored by the Alberta Society of Professional Biologists and Alberta Fish and Wildlife Division, Edmonton.

Hinton, 125 pp.

Alberta Fish and Wildlife Division, Edmonton. Wildlife Management Planning Series Number 1.

Alberta Fish and Wildlife Division. Edmonton. Wildlife Management Planning Series No. 1.

Alberta Fish and Wildlife Division, Edmonton. Wildlife Management Planning Series Number 3.

Alberta Fish and Wildlife Division, Edmonton Wildlife Management Planning Series Number?.

Alberta Fish and Wildlife Division, Edmonton. Wildlife Management Planning Series Number?.

Alberta Fish and Wildlife Division, Edmonton. Wildlife Management Planning Series Number?.

Publication No. 4, Alberta Fish and Wildlife Division, Edmonton.

Publication No. 5, Alberta Fish and Wildlife Division, Edmonton.

Parks Canada, Calgary. Unpublished report.

Alberta Fish and Wildlife Division, Edmonton. Unpublished report.

Proceedings of 9th Biennial Pronghorn Antelope Workshop. Rio Rico, AZ, April 7-10, 1980.

Alberta Fish and Wildlife Division, Edmonton Unpublished report.

Alberta Fish and Wildlife Division, Edmonton Unpublished report.

Department of Animal Science, University of Alberta, Edmonton. Unpublished report.

Alberta Fish and Wildlife Division, Edmonton. Unpublished report.

Proceedings of Western Association Game and Fish Commissioners, 56, 364-366.

Northwest Territories Fish and Wildlife Service. Yellowknife, NWT. Unpublished report.

Canadian Wildlife Service, Edmonton. Unpublished report.

Alberta Fish and Wildlife Division, Edmonton Unpublished report. 


\begin{tabular}{|c|c|c|}
\hline Author(s) / Editor & Date & Title \\
\hline Cool, N.L. & 1987 & $\begin{array}{l}\text { Management alternatives for the moose population of Elk } \\
\text { Island National Park. }\end{array}$ \\
\hline Dixon, F.A. & 1980 & $\begin{array}{l}\text { Plains bison operational management plan. Elk Island } \\
\text { National Park. }\end{array}$ \\
\hline Dixon, F.A. & 1980 & $\begin{array}{l}\text { Wood bison operational management plan. Elk Island } \\
\text { National Park. }\end{array}$ \\
\hline Edmonds, J. & 1986 & Restoration plan for woodland caribou in Alberta. \\
\hline Edwards, B.F. & 1974 & $\begin{array}{l}\text { A resource planning study of the wildlife of Cypress Hills } \\
\text { Provincial Park, Alberta. }\end{array}$ \\
\hline Festa-Bianchet, $\mathbf{M}$. & 1986 & The Sheep River wildlife sanctuary: Success and failures. \\
\hline Flook, D.R. & 1963 & $\begin{array}{l}\text { Some factors to be considered in ungulate management in } \\
\text { Canadian National Parks. }\end{array}$ \\
\hline Flook, D.R. & 1968 & $\begin{array}{l}\text { An appraisal of bison management in Waterton Lakes } \\
\text { National Park. }\end{array}$ \\
\hline Flook, D.R. & 1968 & $\begin{array}{l}\text { Preliminary plan for managing plains bison in Elk Island } \\
\text { National Park. }\end{array}$ \\
\hline Forest, A. & 1984 & $\begin{array}{l}\text { Range management for pronghom antelope in southern } \\
\text { Alberta. }\end{array}$ \\
\hline Fuller, W.A. & 1954 & $\begin{array}{l}\text { The biology and management of the bison of Wood } \\
\text { Buffalo National Park. }\end{array}$ \\
\hline Geist, V. & 1970 & Sheep management dilemmas. \\
\hline Geist, V. & 1974 & $\begin{array}{l}\text { On the management of mountain sheep - theoretical } \\
\text { considerations. }\end{array}$ \\
\hline Geist, V. & 1990 & $\begin{array}{l}\text { Flight to the phoenix: lessons for the future from North } \\
\text { American wildlife management." }\end{array}$ \\
\hline Government of Alberta. & 1984 & Province of Alberta wildlife act. \\
\hline Gunson, J.R. & 1981 & $\begin{array}{l}\text { Problem wildlife management by the Alberta Fish and } \\
\text { Wildlife Division. }\end{array}$ \\
\hline Gunson, J.R. & $\begin{array}{l}\text { (in } \\
\text { prep.) }\end{array}$ & Management plan for elk in Alberta. \\
\hline Gurba, J. and Neave, D. & 1979 & Problem wildlife management manual. \\
\hline Hall, W.K. & 1977 & $\begin{array}{l}\text { Status and management of the Rocky Mountain goat } \\
\text { (Oreamnos americanus) in the province of Alberta. }\end{array}$ \\
\hline Hall, W.K. and Bibaud, J.A. & 1978 & Goats and their management in Alberta. \\
\hline
\end{tabular}

Holsworth, W.N.

1960 Game management in Elk Island National Park.

Kopjar, N.R.

Love, B.E.

Lukiwski, G.M.

Lynch, G.M.

Lynch, G.M.

Lynch, G.M.

Lynch, G.M. and Pall, O.G.
Altematives for bison management in Banff National Park.

Personal observation on the care and management of an elk (wapiti) herd at Elk Island National Park, Alberta, Canada.

Plains bison operational management plan, Elk Island National Park.

Status of moose management in Alberta.

Moose management plan for Alberta.

Technical considerations for moose management in Alberta.

1973 Status of caribou management in Alberta.
Journal / Conference / Etc.

Parks Canada, Calgary. Unpublished report.

Parks Canada, Calgary. Unpublished report.

Parks Canada, Calgary. Unpublished report.

Alberta Fish and Wildlife Division, Edmonton Unpublished report.

M.Sc. Thesis. University of Calgary, Calgary.

Department of Biological Sciences, University of Calgary, Calgary.

Presented to Northwest Section of the Wildlife Society. April 27, 1963. Cranbrook, BC.

Parks Canada, Calgary. Unpublished report.

Canadian Wildlife Service, Edmonton.

Unpublished report.

Rangelands, 6, 34-36.

Ph.D. Thesis. University of Wisconsin, WI.

Transactions of Northern Wild Sheep Council.

Paper presented at Northern Wild Sheep Council.

Intercol 90, Proceedings of the Symposium on Wildlife Conservation. Yokahama, Japan, August 24, 1990.

Queens Printer, Edmonton.

Alberta Fish and Wildlife Division, Edmonton. Unpublished report.

Alberta Fish and Wildlife Division, Edmonton. Unpublished report.

Alberta Agriculture and Energy and Natural Resources, Edmonton.

Alberta Fish and Wildlife Division, Edmonton. Unpublished report.

pp. 142-164. In: Proceedings of the Biennial Symposium of the Northern Wild Sheep and Goat Council. Penticton, BC.

Parks Canada, Calgary. Unpublished report.

M.Sc. Thesis. University of Alberta, Edmonton.

Canadian Journal of Comparative Medicine, 19, 148-192.

Parks Canada, Calgary. Unpublished report.

Alberta Energy and Natural Resources, Fish and Wildlife Division, Edmonton. Unpublished report.

Alberta Fish and Wildlife Division, Edmonton. Unpublished report.

Alberta Fish and Wildlife Division, Edmonton. Unpublished report.

Alberta Fish and Wildlife Division, Edmonton. Unpublished report. 


Author(s) / Editor

Markham, B.J. Date

1972

Mitchell, R.B.

Murphy, P.J.

1984

Influence of government policies on wildlife habitat conditions in Alberta forests.

Northern Affairs and Natural Resources.

1961 History of the buffalo of Buffalo National Park, Wainwright, Alberta.

Novakowski, N.S.

1962 Proposals for a bison management policy.

Novakowski, N.S. and Choquette, 1967 L.P.E.

Ogilivie, S.C.

Parks Canada.

Paulsen, A.

Psikla, E.

Quaedvlieg, M.

Redgate, R.M.

Renecker, L.A.

1991

Reynolds, H.W.

Reynolds, H.W.

1980

Reynolds, H.W.

1980

Reynolds, H.W.

Reynolds, H.W.

Reynolds, H.W., McFetridge, R. 1985 and Didzena, F.

Scotter, G.W.

Smith, K.G.

Stelfox, J.G.

Surrendi, C. and Wishart, W.D.

Surrendi, D.C.

1983

Principles of game management.

An endangered species program brings wood bison to Nahanni.

Proposed 5 year management plan for bison in Wood Buffalo National Park.

The park buffalo. Calgary-Banff Chapter.

Elk Island National Park - management plan.

Predator-ungulate management in big game zones 5 and 7 in region 3.

Legislative and enforcement approaches to antelope management in Alberta.

Sheep management in Alberta.

Behavioural and ecological considerations in the management of elk in Camp 1, Athabasca valley, Alberta.

Status of moose and its management in Canada.

The wood bison rehabilitation program.

The Canadian Wildlife Service program to rehabilitate wood bison

Wood bison - past, present and future.

Proposal for the reintroduction of wood bison to the southwestern Yukon.

A management plan for wood bison in Alberta.

Management of wild ungulate habitat in the western United States and Canada: a review.

Preliminary elk (Cervus elaphus) management plan for the Edson wildlife management area.

Bighom management problems in the Coalbranch region.

Warden Service.

Elk (Cervus cervus manitobensis) operational plan.

Watson, M.
Journal / Conference / Etc.

Alberta Fish and Wildlife Division, Edmonton. Unpublished report.

Section B: pp. 1-43. In: Wood Buffalo National Park bison research: 1972-1976. Stelfox, J.G. (compiler). Prepared for Parks Canada, Calgary; prepared by Canadian Wildlife Service, Edmonton.

Paper presented at the International Forest Congress. Quebec City, PQ

Parks Canada, Calgary. Unpublished report.

Parks Canada, Calgary; Canadian Wildlife Service, Edmonton. Unpublished report.

Parks Canada, Calgary; Canadian Wildlife Service, Edmonton. Unpublished report.

National and Provincial Park Association, Canada.

Parks Canada, Calgary. Unpublished report.

Alberta Fish and Wildlife Division, Edmonton. Unpublished report.

pp. 113-120. In: Proceedings of 8th Biennial Pronghorn Antelope Workshop. Jasper. May 2-4, 1978.

Alberta Fish and Wildlife Division, Edmonton. Unpublished report.

Masters of Environment Design Project. University of Calgary, Calgary.

In: Proceedings of International Baikal Symposium on hunting, game management and conservation of wildlife, Irkutsk, USSR

Canadian Wildlife Service, Edmonton. Unpublished report.

Buffalo, 8, 30 .

Canadian Wildlife Administration, 6, 75-78. Ministry of Natural Resources, Ottawa, ON.

Zoo Nooz, 55, 4-8.

Canadian Wildlife Service, Edmonton. Unpublished report.

Alberta Fish and Wildlife Division, Edmonton. Parks Canada, Calgary. Unpublished report.

Journal of Range Management, 33, 16-27.

Alberta Fish and Wildlife Division, Edmonton. Unpublished report.

Alberta Fish and Wildlife Division, Edmonton. Unpublished report.

Alberta Lands, Forests, Parks, Wildlife, 10, 20.

pp. 67-76. In: Symposium on Fish and Wildlife Resources and Economic Development.

Edmonton. April 26-27, 1983.

Elk Island National Park, Parks Canada, Calgary. Unpublished report.

Alberta Fish and Wildlife Division, Edmonton. Unpublished report. 
Management Theory/Policy

\begin{tabular}{|c|c|c|c|}
\hline Author(s) / Editor & Date & Title & Journal / Conference / Etc. \\
\hline Webb, R. & 1961 & $\begin{array}{l}\text { Management suggestions for the Ya-Ha-Tinda "Comers" } \\
\text { elk winter range, 1960-1961. }\end{array}$ & Alberta Fish and Wildlife Division, Edmonton. \\
\hline Willman, J. & 1980 & $\begin{array}{l}\text { Moose (Alces alces andersoni) operational management } \\
\text { plan. }\end{array}$ & Elk Island National Park, Parks Canada, Calgary. \\
\hline Wishart, W. & 1971 & Wildlife management proposals for Camp Wainwright. & $\begin{array}{l}\text { Alberta Fish and Wildlife Division, Edmonton. } \\
\text { Unpublished report. }\end{array}$ \\
\hline Wishart, W. & 1972 & $\begin{array}{l}\text { History and management of the pronghom antelope in } \\
\text { Alberta. }\end{array}$ & Alberta Conservation , 1, 20-22. \\
\hline Wishart, W. & 1979 & Regional management of white-tailed deer and their habitat. & $\begin{array}{l}\text { Alberta Fish and Wildlife Division, Edmonton. } \\
\text { Unpublished report. }\end{array}$ \\
\hline Wishart, W. & 1979 & $\begin{array}{l}\text { Species management plan for the Rocky Mountain bighorn } \\
\text { sheep in Alberta. Part } 1 \text {. An overview of the status and } \\
\text { management of bighorns in North America. }\end{array}$ & $\begin{array}{l}\text { Alberta Fish and Wildlife Division, Edmonton. } \\
\text { Unpublished report. }\end{array}$ \\
\hline Wishart, W. & 1979 & $\begin{array}{l}\text { Species management plan for the Rocky Mountain bighorn } \\
\text { sheep in Alberta. Part } 2 \text {. Status and distribution of } \\
\text { Alberta's bighorns. }\end{array}$ & $\begin{array}{l}\text { Alberta Fish and Wildlife Division, Edmonton. } \\
\text { Unpublished report. }\end{array}$ \\
\hline
\end{tabular}




\begin{tabular}{|c|c|c|}
\hline Author(s) / Editor & Date & Title \\
\hline Armstrong, G. & 1967 & $\begin{array}{l}\text { Prairie deer sex and age characteristics from hunter } \\
\text { harvests, } 1966 .\end{array}$ \\
\hline Blood, D.A. & 1962 & $\begin{array}{l}\text { Game population and range studies Elk Island Park; } \\
\text { project plan. }\end{array}$ \\
\hline Bruns, E.H. & 1976 & $\begin{array}{l}\text { Recent changes in Alberta's mule deer populations and } \\
\text { management. }\end{array}$ \\
\hline Clarke, C.H.D. & 1949 & Fluctuations in populations. \\
\hline Dekker, D. & 1985 & $\begin{array}{l}\text { Elk population fluctuations and their probable causes in the } \\
\text { Snake Indian Valley of Jasper National Park: } 1970-1985 .\end{array}$ \\
\hline Frokjer, $\mathbf{R}$. & 1976 & Historical moose data at Rochester, Alberta. \\
\hline Frokjer, R. and Keith, L.B. & 1976 & $\begin{array}{l}\text { An analysis of moose population changes at Rochester, } \\
\text { Alberta, based on ten winters of aerial surveys. }\end{array}$ \\
\hline Fuller, T.K. and Keith, L.B. & 1981 & $\begin{array}{l}\text { Woodland caribou population dynamics in northeastern } \\
\text { Alberta. }\end{array}$ \\
\hline Green, H.U. & 1950 & $\begin{array}{l}\text { The productivity and sex survival of elk, Banff National } \\
\text { Park, Alberta. }\end{array}$ \\
\hline Gudmundson, L. & 1984 & $\begin{array}{l}1983 \text { preseason prairie mule deer classification program } \\
\text { (G116, G118, G119 and G148). }\end{array}$ \\
\hline Gudmundson, L. & 1985 & 1985 preseason prairie mule deer classification survey. \\
\hline
\end{tabular}

Hauge, T.M. and Keith, L.B.

Hauge, T.M. and Keith, L.B.

Jorgenson, J.

Jorgenson, J.T.

1991

Jorgenson, J.T. and Wishart, W.D. 1986

Le Blanc, R. and Mamo, G.

Lynch, G.M.

1968

Lynch, G.M.

1972

Mitchell, G.J.

1972

Mytton, W.R. and Keith, L.B.

Nette, T. and Leblanc, R.

1985 Moose sex and ratio survey of the Rocky Mtn. House area. (Dec. 11-14 and Feb. 18-21, 1985).

Paulsen, A.C.

1973 Alberta mule deer age data from hunter harvest, 1969-1972 inclusive.

Rolley, R.E. and Keith, L.B.

1980 Moose population dynamics and winter habitat use at Rochester, Alberta. 1965-79.

Smith, C.

1987 Population dynamics of caribou in the Blue Creek Valley, Jasper National Park.

Smith, K.

1988 Factors affecting the population dynamics of mountain goats in west central Alberta.

Stelfox, J.G.

1968 Population dynamics and range ecology of bighorn sheep in Rocky Mountain National Parks. Phase No. 1 population fluctuations of bighorn sheep in the Canadian Rocky Mountains from 1800 to 1967.
Journal / Conference / Etc.

Alberta Fish and Wildlife Division, Edmonton Unpublished report.

Canadian Wildlife Service, Edmonton. Unpublished report.

Proceedings of Western Association of Game and Fish Commissioners, 56, 364-366.

Journal of Mammalogy, 30, 21-25.

Alberta Naturalist, 15, 49-54.

Alberta Fish and Wildlife Division, Edmonton. Unpublished report.

Alberta Fish and Wildlife Division, Edmonton. Unpublished report.

Journal of Wildlife Management, 45, 197-213.

Canadian Field Naturalist, 64, 40-42.

Alberta Fish and Wildlife Division, Edmonton. Unpublished report.

Alberta Fish and Wildlife Division, Edmonton. Unpublished report.

Department of Wildlife Ecology, University of Wisconsin, Madison, WI.

Journal of Wildlife Management, 45, 573-597.

Alberta Fish and Wildlife Division, Edmonton. Unpublished report.

Abstract from Alberta Chapter of the Wildlife Society, 2nd Annual meeting. March 23 and 24, 1991, Edmonton.

Biennial Symposium Northern Wild Sheep and Goat Council, 5, 348-362.

Alberta Fish and Wildlife Division, Edmonton. Unpublished report.

Alberta Fish and Wildlife Division, Edmonton. Unpublished report.

Alberta Fish and Wildlife Division, Edmonton. Unpublished report.

Proceedings of Biennial Antelope States Workshop, 5, 66-77.

Canadian Field Naturalist, 95, 39-49.

Alberta Fish and Wildlife Division, Edmonton. Unpublished report.

Alberta Fish and Wildlife Division, Edmonton. Unpublished report.

Canadian Field Naturalist, 94, 9-18.

Parks Canada, Calgary. Unpublished report.

Alberta Fish and Wildlife Division, Edmonton. Unpublished report.

Canadian Wildlife Service, Edmonton. Unpublished report. 


Author(s) / Editor

Stelfox, J.G.

Sturko, A.N

Treichel, B.

Treichel, B.

Treichel, B.

Treichel, B.

Treichel, B.

Treichel, B.

Treichel, B.

Treichel, B.

Treichel, B.

Treichel, B.

Treichel, B.

Treichel, B.

Treichel, B.

Treichel, B

Treichel, B.

Treichel, B. and Hall, B.

Treichel, B. and Hall, B.

Treichel, B. and Hall, B.

Treichel, B. and Hall, B.

Treichel, B. and Hall, B.

Turnbull, J.L.

Winkler, $\mathrm{T}$.
Date

Title

Journal / Conference / Etc.

1971 Bighorn sheep in the Canadian Rockies: a history 1800-1970.

1963 Ecology of the Rocky Mountain bighorn sheep, Waterton Lakes National Park.

1977 Incisor bar ages: annual report.

1978 Antelope ages.

1978 Antlerless mule deer ages.

1978 Incisor bar ages: annual report.

$1979 \quad$ Big game ages 1978.

1979 Incisor bar ages: annual report.

1980 Incisor bar ages: annual report.

1981 Big game ages 1980.

1981 Incisor bar ages: annual report.

1982 Incisor bar ages: annual report.

1983 Incisor bar ages: annual report.

1984 Incisor bar ages: annual report.

1985 Incisor bar ages: annual report.

1986 Incisor bar ages. Annual report.

19871987 Incisor bar age data report. Annual report.

$1978 \quad$ Antelope ages 1977.

1978 Antlerless mule deer ages 1977.

$1978 \quad$ Antlerless white-tail ages 1977.

1978 Antlerless white-tailed deer ages.

$1978 \quad$ Non-trophy sheep ages 1977.

1975 Disaster range study - Jasper National Park, 1972-1975.

1990 Population dynamics of elk in the Borgeau district, Jasper National Park. Unpublished report.
Canadian Field Naturalist, 85, 101-122.

Parks Canada, Calgary. Unpublished report.

Alberta Fish and Wildlife Division, Edmonton. Unpublished report.

Alberta Fish and Wildlife Division, Edmonton. Unpublished report.

Alberta Fish and Wildlife Division, Edmonton. Unpublished report.

Alberta Fish and Wildlife Division, Edmonton. Unpublished report.

Alberta Fish and Wildlife Division, Edmonton. Unpublished report.

Alberta Fish and Wildlife Division, Edmonton. Unpublished report.

Alberta Fish and Wildlife Division, Edmonton. Unpublished report.

Alberta Fish and Wildlife Division, Edmonton. Unpublished report.

Alberta Fish and Wildlife Division, Edmonton. Unpublished report.

Alberta Fish and Wildlife Division, Edmonton. Unpublished report.

Alberta Fish and Wildlife Division, Edmonton. Unpublished report.

Alberta Fish and Wildlife Division, Edmonton. Unpublished report.

Alberta Fish and Wildlife Division, Edmonton. Unpublished report.

Alberta Fish and Wildlife Division, Edmonton. Unpublished report.

Alberta Fish and Wildlife Division, Edmonton. Unpublished report.

Alberta Fish and Wildlife Division, Edmonton. Unpublished report.

Alberta Fish and Wildlife Division, Edmonton. Unpublished report.

Alberta Fish and Wildlife Division, Edmonton. Unpublished report.

Alberta Fish and Wildlife Division, Edmonton. Unpublished report.

Alberta Fish and Wildlife Division, Edmonton.

Parks Canada, Calgary. Unpublished report.

Parks Canada, Calgary. Unpublished report. 


Author(s) / Editor

Armstrong, G.G. Date

Title

1966 Coyote depredation on antelope in the Drumheller and Medicine Hat areas.

Banfield, A.W.F. and

Novakowski, N.S.

Barrett, M.W.

1960 The survival of the wood bison (Bison bison athabascae Rhoads) in the Northwest Territories.

1978 Pronghom fawn mortality in Alberta.

Barrett, M.W.

1982 Distribution, behavior, and mortality of pronghorns during a severe winter in Alberta.

Bjorge, R.R.

1977 Analysis of wolf scats and kills in the Peace River region of Alberta 1975-77.

Bjorge, R.R. and Gunson, J.R.

1987 Wolf population characteristics and prey relationships near Simonette, Alberta.

Bjorge, R.R. and Meyers, S.M.

1978 Analysis of wolf scats and kills on or near the Simonette cattle leases: 1975-1978.

Brady, K.S. and Wackerle, J.

Bruns, E.H.

1970

Burstrom, A.F.

1972

Carbyn, L.

Carbyn, L.N.

Carbyn, L.N.

Carbyn, L.N. and Trottier, T.

Carbyn, L.N., Samoil, H. and Fau, 1977 J.F.

Carbyn, L.N., Trottier, T. and

Oosenbrug, S.

Clarkson, P.L., Schmidt, K.P. and 1984

Gunson, J.R.

Cole, P.J. and Bjorge, R.R.

Cowan, I. McT.

Cunningham, E.B.

1970

Cunningham, E.B.

Fau, J.F. and Tempany, I.R.

Festa-Bianchet, M.

1983

Festa-Bianchet, M.

Festa-Bianchet, M.

Festa-Bianchet, M.

1989

Flook, D.R.

Fuhrer, H.

1972
Wolf activity in the Clearwater Valley.

Winter predation of golden eagles and coyotes on pronghorn antelopes.

Report on elk and wolf activity, Yellowhead District, November and December, 1972.

Life tables of elk under different wolf predation pressures.

Wolf predation and behavioural interactions with elk and other ungulates in an area of high prey diversity.

Wolf predation and the decline of the bison in Wood Buffalo National Park.

Responses of bison on calving predation by wolves in Wood Buffalo National Park.

Wolf-bison: predator-prey relationships in Wood Buffalo National Park.

Summer (1980) observations of wolf-bison behavioural interactions in Wood Buffalo National Park.

Evaluation of wolf-ungulate predation near Nordegg, Alberta: first year progress report, 1983-84.

Analysis of wolf scats: 1975-1976.

The timber wolf in the Rocky Mountain National Parks of Canada.

A cougar kills an elk.

A golden eagle harassing bighorn sheep.

Wolf observations from aerial bison surveys 1972-76.

Bighom sheep die-off in the Waterton-Crowsnest Pass area.

Bighorn sheep, climbing accidents, and implications for mating strategy.

Birthdate and survival in bighorn lambs (Ovis canadensis).

Survival of male bighom sheep in southwestern Alberta.

Causes and implications of an observed sex differential in the survival of wapiti.

Report on wolf kill (cow moose).
Journal / Conference / Etc.

Alberta Fish and Wildlife Division, Edmonton. Unpublished report.

National Museum of Canada Natural History Paper 8. Ottawa, ON.

Proceedings of Biennial Pronghom Antelope Workshop, 8, 429-444.

Joumal of Wildlife Management, 46, 991-1002.

Alberta Fish and Wildlife Division, Edmonton. Unpublished report.

Alberta Fish and Wildife Division, Edmonton. Unpublished report.

Alberta Fish and Wildlife Division, Edmonton. Unpublished report.

Banff National Park, Parks Canada, Calgary. Unpublished report.

Canadian Field Naturalist, 84, 301-304.

Parks Canada, Calgary. Unpublished report.

Canadian Wildlife Service, Edmonton. Unpublished report.

Ph.D. Thesis. University of Toronto, Toronto, ON.

Abstract from Alberta Chapter of the Wildlife Society, 2nd Annual meeting. March 23 and 24, 1991, Edmonton.

Canadian Joumal of Zoology, 65, 2072-2078.

In: Bison research 1977 annual report. Canadian Wildlife Service, Edmonton.

Canadian Wildlife Service, Edmonton. Unpublished report.

Alberta Fish and Wildlife Division, Edmonton. Unpublished report.

Alberta Fish and Wildlife Division, Edmonton. Unpublished report.

Canadian Journal of Research, 25, 139-174.

Canadian Field Naturalist, 85, 253-254.

Canadian Field Naturalist, 84, 183.

Section I: pp. 1-14. In: Wood Buffalo National Park bison research 1972-1976. Stelfox, J.G. (complier). Prepared for Parks Canada, Calgary; prepared by Canadian Wildlife Service, Edmonton.

Alberta Fish and Wildlife Division, Edmonton. Unpublished report.

Mammalia, 51, 618-620.

Journal of Zoology, 214, 653-661.

Journal of Wildlife Management, 53, 259-263.

Canadian Wildlife Service Report Series No. 11.

Jasper National Park, Parks Canada, Calgary.

Unpublished report. 


\begin{tabular}{|c|c|c|}
\hline Author(s) / Editor & Date & Title \\
\hline Fuller, T.K. and Keith, L.B. & 1980 & $\begin{array}{l}\text { Wolf population dynamics and prey relationships in } \\
\text { northeastem Alberta. }\end{array}$ \\
\hline Green, H.U. & 1951 & The wolves of Banff National Park. \\
\hline Gunson, J.R. & 1973 & Predators and predator management. \\
\hline Gunson, J.R. & 1983 & $\begin{array}{l}\text { Wolf-ungulate predation in North America. Review of } \\
\text { major studies. }\end{array}$ \\
\hline Gunson, J.R. & 1984 & $\begin{array}{l}\text { Review of management and research of wolf - big game } \\
\text { predation in Alberta. }\end{array}$ \\
\hline Gunson, J.R. & 1987 & Wolves and elk in Alberta's Brazeau country. \\
\hline Gunson, J.R. and Schmidt, K.P. & 1985 & $\begin{array}{l}\text { Evaluation of wolf-ungulate predation near Nordegg, } \\
\text { Alberta: second year progress report, 1984-85. }\end{array}$ \\
\hline Hall, W.R. & 1973 & $\begin{array}{l}\text { Natality and mortality of white-tailed deer in Camp } \\
\text { Wainwright, Alberta. }\end{array}$ \\
\hline Jalkotzy, M. & 1979 & $\begin{array}{l}\text { Wolf-bison project, Slave River Lowlands, N.W.T.; } \\
\text { completion report. }\end{array}$ \\
\hline Jalkotzy, $\mathrm{M}$ and Ross, I. & 1991 & $\begin{array}{l}\text { The Sheep River cougar project phase III cougar/prey } \\
\text { relationships }\end{array}$ \\
\hline $\begin{array}{l}\text { Jalkotzy, P.S. and Oosenbrug, } \\
\text { S.M. }\end{array}$ & 1982 & $\begin{array}{l}\text { Summer food habits of wolves in Wood Buffalo National } \\
\text { Park, Alberta, } 1980 \text {. }\end{array}$ \\
\hline Kansas, J.L. & 1981 & $\begin{array}{l}\text { A wolf-elk predator-prey interaction in Jasper National } \\
\text { Park. }\end{array}$ \\
\hline Kennedy, A.J. and Carbyn, L.N. & 1981 & $\begin{array}{l}\text { Identification of wolf prey using hair and feather remains } \\
\text { with special reference to western Canadian National Parks. }\end{array}$ \\
\hline Khatzer, P. & 1972 & $\begin{array}{l}\text { Wildlife mortality - unnatural causes. Winter 1971/1972 - } \\
\text { area } 1 .\end{array}$ \\
\hline Kutzer, P. & 1972 & $\begin{array}{l}\text { Wildlife mortality - unnatural causes, winter 1971-1972. } \\
\text { Area I. }\end{array}$ \\
\hline Kutzer, P. & 1974 & $\begin{array}{l}\text { Winter mortality summary and comparison - Banff } \\
\text { National Park. }\end{array}$ \\
\hline Mitchell, G.J. & 1960 & $\begin{array}{l}\text { Deer mortality investigations: Cypress Hills Provincial } \\
\text { Park. }\end{array}$ \\
\hline
\end{tabular}

Oosenbrug, S. and Carbyn, L.

Oosenbrug, S. and Carbyn, L.

Oosenbrug, S., Carbyn, L.N. and Anions, D.

Oosenbrug, S., Carbyn, L.N. and West, D.

Rippin, B.

Ross, I. and Jalkotzy, M.

Ross, I. and Jalkotzy, M.

Ross, P.I., and Jalkotzy, M.G.

Schaefer, M.

Smith, K.
Journal / Conference / Etc.

Joumal of Wildlife Management, 44, 583-602.

Canada Parks Service report.

No. 7, Wildlife Management Series, Alta. Fish and Wildlife Division, Edmonton.

Alberta Fish and Wildlife Division, Edmonton. Unpublished report.

Alberta Fish and Wildlife Division, Edmonton. Unpublished report.

pp. 29-33. In: Bugle: The Quarterly Journal of the Rocky Mountain Elk Foundation.

Alberta Fish and Wildlife Division, Edmonton. Unpublished report.

M.Sc. Thesis. University of Calgary, Calgary.

Northwest Territories Wildlife Service.

Yellowknife, NWT. Unpublished report.

Arc Associated Resource Consultants Ltd.

Alberta Naturalist, 12, 157-167.

Alberta Naturalist, 11, 78-80.

Canadian Wildlife Service, Edmonton. Unpublished report.

Banff National Park, Parks Canada, Calgary. Unpublished report.

Canada Parks Service.

Canada Parks Service.

Alberta Fish and Wildlife Division, Edmonton. Unpublished report.

In: Proceedings of Portland Wolf Symposium. Harrington, F. and Paquet, P. (eds.). Portland, OR.

Canadian Wildlife Service, Edmonton. Unpublished report.

Progress report No. 3. Prepared for Parks Canada, Calgary, prepared by Canadian Wildlife Service, Edmonton. Unpublished report.

Prepared for Parks Canada, Calgary, prepared by Canadian Wildlife Service, Edmonton. Unpublished report.

Alberta Fish and Wildlife Division, Edmonton. Unpublished report.

Arc Associated Resource Consultants Ltd.

Arc Associated Resource Consultants Ltd.

Abstract from Alberta Chapter of the Wildlife Society, 2nd Annual meeting. March 23 and 24, 1991, Edmonton.

Parks Canada, Calgary. Unpublished report.

Alberta Fish and Wildlife Division, Edmonton. Unpublished report. 
Predation/Natural Mortality

\begin{tabular}{|c|c|c|c|}
\hline Author(s) / Editor & Date & Title & Journal / Conference / Etc. \\
\hline Smith, K. & 1988 & $\begin{array}{l}\text { Factors affecting mountain goat production and survival in } \\
\text { west central Alberta. }\end{array}$ & $\begin{array}{l}\text { Biennial Symposium Northern Wild Sheep and } \\
\text { Goat Council, 6, 308-329. }\end{array}$ \\
\hline Smith, K.G., and Urquhart, M.A. & 1991 & $\begin{array}{l}\text { Observations of timing and causes of mountain goat kid } \\
\text { mortality in west central Alberta. }\end{array}$ & $\begin{array}{l}\text { Abstract from Alberta Chapter of the Wildlife } \\
\text { Society, 2nd Annual meeting. March } 23 \text { and 24, } \\
\text { 1991, Edmonton. }\end{array}$ \\
\hline Stelfox, J.G. & 1973 & Predator-prey relationships in Canadian national parks. & $\begin{array}{l}\text { Canadian Wildlife Service, Edmonton. } \\
\text { Unpublished report. }\end{array}$ \\
\hline Tempany, I.R. & 1974 & $\begin{array}{l}\text { Bison losses in the Peace-Athabasca Delta flood, April } 25 \\
\text { to May } 5,1974 .\end{array}$ & $\begin{array}{l}\text { Parks Canada, Calgary; Canadian Wildlife } \\
\text { Service, Edmonton. Unpublished report. }\end{array}$ \\
\hline Theberge, J.B. and Gauthier, D.A. & 1985 & $\begin{array}{l}\text { Models of wolf-ungulate relationships: When is wolf } \\
\text { control justified? }\end{array}$ & Wildlife Society Bulletin 13, 449-458, 1985. \\
\hline Van Camp, J. & 1978 & $\begin{array}{l}\text { Summary of progress, wolf-bison project, Slave River } \\
\text { lowlands, N.W.T. - May } 24,1978 \text {. }\end{array}$ & $\begin{array}{l}\text { Northwest Territories Fish and Wildlife Service. } \\
\text { Yellowknife, NWT. Unpublished report. }\end{array}$ \\
\hline Van Camp, J. & 1987 & Predation in bison. & $\begin{array}{l}\text { In: Bison ecology in relation to agricultural } \\
\text { development in the Slave River lowlands, } \\
\text { Northwest Territories. Reynolds. H. and } \\
\text { Hawley, A. (eds.). Canadian Wildlife Service } \\
\text { Occasional Paper (in press). }\end{array}$ \\
\hline
\end{tabular}

Van Tighem, K.J., Kansas, J.L.,
Jesperson, B. and Allison, P.

1980 An incident of wolf predation on sheep and elk in Jasper National Park, Alberta.

Alberta Naturalist, 10, 61-63. 


\begin{tabular}{|c|c|c|}
\hline Author(s) / Editor & Date & Title \\
\hline Allen, J. & 1988 & $\begin{array}{l}\text { Aerial survey of the Ann and Sandy Cross conservation } \\
\text { area. }\end{array}$ \\
\hline Allen, J. & 1988 & Black diamond elk survey (Mar. 15 and 16, 1988). \\
\hline Allen, J.R. & 1985 & $\begin{array}{l}\text { Aerial survey for ungulates Priddis-Millarville and Bragg } \\
\text { Creek areas, January 28, } 1985 \text { and March 22, } 1985 \text {. }\end{array}$ \\
\hline Allen, J.R. & 1989 & Black diamond elk survey (Mar. 1, 1989). \\
\hline Allen, J.R. & 1989 & Deer survey in WMU 158 (Jan. 19, 1989). \\
\hline Allen, J.R. & 1991 & Black Diamond elk survey, January 3, 1991. \\
\hline Anonymous. & 1975 & 1975 Saddle Hills moose and elk survey. \\
\hline
\end{tabular}

Anonymous.

1975 Aerial surveys conducted by the wildlife surveys section, 1974-75 fiscal year.

Anonymous.

1977 Ungulate aerial survey program - Cypress Hills Provincial Park. Survey report No. 1, Dec. 20 and 21, 1977.

Anonymous.

1978 Ungulate aerial survey program - Cypress Hills Provincial Park. Survey report No. 2. Feb. 14, 1978.

Arbuckle, R.

1984 Survey of Manning, Spirit River and Smoky River (Kakut Creek to Watino) elk winter ranges, 17 and 19 January, 1984.

Arbuckle, R.

1985 Summary report of the 1983-1984 caribou monitoring program near Dixonville, Alberta.

Arbuckle, R.

1985 Western Saddle Hills aerial transect ungulate survey WMU F358 - 11, February, 1985.

Arbuckle, R.G. and Verbeurgt, D. 1983

Arbuckle, R.G. and Verbeurgt, D. 1984

Arbuckle, R.G. and Verbeurgt, D. 1984

Arbuckle, R.G. and Verbeurgt, D. 1985

Armstrong, G.

Armstrong, G.

Armstrong, G.

Armstrong, G.

Balagus, P.

Barker, M. and Nibourg, J.

Barrett, M.W.

Barrett, M.W.

Barrett, M.W. and Capelle, A.D.

Bibaud, A.
1966

1966

1967 A preliminary survey of elk and moose populations in the Cypress Hills.

1968 Antelope aerial surveys, 1968.

WMU M354 aerial transect moose survey, December 12-14, 1983.

WMU F351 aerial transect ungulate survey 4, 5 December, 1984.

WMU M521 aerial transect ungulate survey, December 3 and 5, 1984.

WMU M522 aerial transect ungulate survey, 3 December 1984, 10 January, 1985.

Big game aerial surveys of the foothills and sub-alpine areas, 1967

Prainie deer aerial surveys, 1966-1967.

A stratified habitat moose density survey for WMU 316 and 318, February - March, 1989.

Sturgeon Lake - Spring Creek ungulate survey - January 4 and $5,1978$.

Antelope aerial surveys and estimated populations.

Wildlife survey, Cypress Hills Provincial Park, Dec. 1972.

December 20, 21, 1977. Ungulate aerial survey: Cypress Hills Provincial Park (Alberta), west block and centre block, (Saskatchewan).
Journal / Conference / Etc.

Alberta Fish and Wildlife Division, Edmonton. Unpublished report.

Alberta Fish and Wildlife Division, Edmonton. Unpublished report.

Alberta Fish and Wildlife Division, Edmonton. Unpublished report.

Alberta Fish and Wildlife Division, Edmonton. Unpublished report.

Alberta Fish and Wildlife Division, Edmonton. Unpublished report.

Alberta Fish and Wildlife Division, Edmonton. Unpublished report.

Alberta Fish and Wildlife Division, Edmonton. Unpublished report.

Alberta Fish and Wildlife Division, Edmonton. Unpublished report.

Alberta Fish and Wildlife Division, Edmonton. Unpublished report.

Alberta Fish and Wildlife Division, Edmonton. Unpublished report.

Alberta Fish and Wildlife Division, Edmonton. Unpublished report.

Alberta Fish and Wildlife Division, Edmonton Unpublished report.

Alberta Fish and Wildlife Division, Edmonton Unpublished report.

Alberta Fish and Wildlife Division, Edmonton Unpublished report.

Alberta Fish and Wildlife Division, Edmonton Unpublished report

Alberta Fish and Wildlife Division, Edmonton. Unpublished report.

Alberta Fish and Wildlife Division, Edmonton Unpublished report.

Alberta Fish and Wildlife Division, Edmonton Unpublished report.

Alberta Fish and Wildlife Division, Edmonton Unpublished report.

Alberta Fish and Wildlife Division, Edmonton. Unpublished report.

Alberta Fish and Wildlife Division, Edmonton Unpublished report.

Alberta Fish and Wildlife Division, Edmonton Unpublished report.

Alberta Fish and Wildlife Division, Edmonton. Unpublished report.

Alberta Fish and Wildlife Division, Edmonton Unpublished report.

Alberta Fish and Wildlife Division, Edmonton Unpublished report.

Alberta Fish and Wildlife Division, Edmonton. Unpublished report.

Alberta Fish and Wildlife Division, Edmonton. Unpublished report. 


\begin{tabular}{lcc}
\hline Author(s) / Editor & Date & Title \\
\hline Bibaud, A. & 1972 & Fort McMurray ungulate survey on township lines.
\end{tabular}

Bibaud, A.

1973 Fort McMurray ungulate survey of the minable portion of the bituminous (tar) sands area (number 1).

Bibaud, A.

1973 Wolf Lake moose survey.

Bibaud, A.

1976 Suffield winter habitat survey.

Bibaud, A.

1978 Alder Flats moose survey, January 7-13, 1978.

Bibaud, A.

1978 Smoky River elk survey. February 2, 1978.

Bibaud, A.

1979 Alder Flats moose survey, January 16-17, 1979.

Bibaud, A.

1979 An aerial moose density survey of the Nordegg, Brazeau and Pembina zone II areas.

Bibaud, A.

1979 Region 3 summer goat survey. June 25-27, 1979.

Bibaud, A.

1979 Region 4 summer goat survey (Willmore area), July 5-9. 1979.

Bibaud, A.

1980 An aerial moose density survey of the Nordegg, Brazeau and Pembina zone II areas, 1979.

Bibaud, A.

1980 Region 4 summer goat survey (Willmore area), July 7-10. 1980.

Bibaud, A. and Archer, T.

1973 Fort McMurray ungulate survey of the minable portion of the bituminous (tar) sands area (number 2).

Bibaud, A. and Dialman, A.

1980 Region 4 sheep survey.

Bibaud, A. and Hall, B.

1977 Ya-Ha-Tinda elk survey (prehunt).

Bibaud, A. and Hall, B.

19811976 summer goat survey of the Whitegoat, Siffleur, and Ghost Wilderness Parks, Shunda Mountain, and the Canmore and Kananaskis areas.

Bicknell, J., Carr, H.D. and Pall, O.

Birkholz, T.

Winter aerial survey of foothills moose in the Waiparous area in 1986.

Stratified random aerial deer census of wildlife management units P222 and P226 using landsat imagery and the double observer (front-back) quadrat procedure (Feb. 8, 11, 1983).

Brebber, B.

1979 Region II foothills aerial moose survey (Waiparous and Pekisko areas), February 8-17, 1979.

Brebber, B. and Hall, W.K.

1979 Caribou survey in the Caribou Mountains, January 8-11, 1979.

Bruns, E.H.

Bruns, E.H.

Bruns, E.H.

Bruns, E.H.

1979

Bruns, E.H.

Bruns, E.H.

Pine Lake deer survey using fixed wing on transect lines.

Region 3 elk survey of known wintering ranges.

Bruns, E.H.
Journal / Conference / Etc.

Alberta Fish and Wildlife Division, Edmonton. Unpublished report.

Alberta Fish and Wildlife Division, Edmonton. Unpublished report.

Alberta Fish and Wildlife Division, Edmonton. Unpublished report.

Alberta Fish and Wildlife Division, Edmonton. Unpublished report.

Alberta Fish and Wildlife Division, Edmonton. Unpublished report.

Alberta Fish and Wildlife Division, Edmonton. Unpublished report.

Alberta Fish and Wildlife Division, Edmonton. Unpublished report.

Alberta Fish and Wildlife Division, Edmonton. Unpublished report.

Alberta Fish and Wildlife Division, Edmonton. Unpublished report.

Alberta Fish and Wildlife Division, Edmonton. Unpublished report.

Alberta Fish and Wildlife Division, Edmonton. Unpublished report.

Alberta Fish and Wildlife Division, Edmonton. Unpublished report.

Alberta Fish and Wildlife Division, Edmonton. Unpublished report.

Alberta Fish and Wildlife Division, Edmonton. Unpublished report.

Alberta Fish and Wildlife Division, Edmonton. Unpublished report.

Alberta Fish and Wildlife Division, Edmonton. Unpublished report.

Alberta Fish and Wildlife Division, Edmonton. Unpublished report.

Alberta Fish and Wildlife Division, Edmonton. Unpublished report.

Alberta Fish and Wildlife Division, Edmonton. Unpublished report.

Alberta Fish and Wildlife Division, Edmonton. Unpublished report.

Alberta Fish and Wildlife Division, Edmonton. Unpublished report.

Alberta Fish and Wildlife Division, Edmonton. Unpublished report.

Alberta Fish and Wildlife Division, Edmonton. Unpublished report.

Alberta Fish and Wildlife Division, Edmonton.

Alberta Fish and Wildlife Division, Edmonton. Unpublished report.

Alberta Fish and Wildlife Division, Edmonton. Unpublished report.

Alberta Fish and Wildlife Division, Edmonton. Unpublished report. 


\begin{tabular}{|c|c|c|}
\hline Author(s) / Editor & Date & Title \\
\hline Carr, H.D. & 1971 & $\begin{array}{l}\text { Aerial survey of Suffield Military Reserve, February } 15 \\
\text { and } 16,1971 .\end{array}$ \\
\hline Carr, H.D. and Scheffler, E. & 1969 & Calgary aerial survey. \\
\hline Carr, H.D., Lukey, A. and Pall, O. & 1985 & $\begin{array}{l}\text { Winter aerial survey of foothills moose in the Elbow and } \\
\text { Sheep River areas in } 1985 \text {. }\end{array}$ \\
\hline Clark, J. & 1980 & Region I elk survey, February 16 and 17, 1980. \\
\hline Clark, J. & 1983 & $\begin{array}{l}\text { Foothills mule deer classification survey (F302 and F306), } \\
\text { December 14, } 1982 \text {. }\end{array}$ \\
\hline Cole, D. & 1978 & Region I prairie deer survey, January 7-13, 1978. \\
\hline Cole, D. & 1984 & Fort McMurray ungulate survey, February 6-9, 1984. \\
\hline Cole, D. and Froggatt, $K$. & 1979 & $\begin{array}{l}\text { Aerial ungulate survey of WMU F348 (Edson region) on } \\
\text { February } 22 \text { and } 28,1979 .\end{array}$ \\
\hline Cook, A.R. & 1975 & Aerial goat survey of Shunda mountain. \\
\hline Cook, A.R. & 1978 & $\begin{array}{l}\text { Aerial goat survey of the Kananaskis area August 2-3, } \\
1978 \text {. }\end{array}$ \\
\hline Cook, A.R. & 1978 & $\begin{array}{l}\text { Aerial sheep survey of the Edson, Red Deer and Calgary } \\
\text { regions using the revised winter range technique. }\end{array}$ \\
\hline Cook, A.R. & 1978 & $\begin{array}{l}\text { Ya-Ha-Tinda (S416-S418) post hunt elk survey. February } \\
15-16,1978 .\end{array}$ \\
\hline Cook, A.R. & 1979 & $\begin{array}{l}\text { Antelope aerial survey and population analysis, July } \\
16-23,1979 \text {. }\end{array}$ \\
\hline Cook, A.R. & 1980 & $\begin{array}{l}\text { Antelope aerial survey and population analysis, July } \\
14-21,1980 \text {. }\end{array}$ \\
\hline Cook, A.R. & 1980 & Calgary regional goat survey, July 3-5, 1980. \\
\hline Cook, A.R. & 1980 & $\begin{array}{l}\text { Provincial bighorn sheep survey, November } 16,1971 \text { - } \\
\text { January } 27,1972 \text {. }\end{array}$ \\
\hline Cook, A.R. & 1980 & $\begin{array}{l}\text { Stratified random deer census design and trial for wildlife } \\
\text { management units P208, P210 and P220 using the double } \\
\text { observer (front-back) quadrat procedure, January } 14-22 \text {, } \\
1980 \text {. }\end{array}$ \\
\hline Cook, A.R. & 1980 & $\begin{array}{l}\text { Stratified random white-tailed deer survey design and trial } \\
\text { census for wildlife management unit P200 using the } \\
\text { double observer (front-back) quadrat procedure, February } \\
\text { 3-8, } 1979 \text {. }\end{array}$ \\
\hline Cook, A.R. & 1981 & $\begin{array}{l}\text { Antelope aerial survey and population analysis. July } \\
20-28,1981 \text {. }\end{array}$ \\
\hline Cook, A.R. & 1982 & $\begin{array}{l}\text { Aerial bighorn sheep census of designated winter ranges } \\
\text { within the Edson district of the east slopes region. }\end{array}$ \\
\hline Cook, A.R. & 1982 & $\begin{array}{l}\text { Stratified random deer census of wildlife management unit } \\
\text { P224, P246 and P334 using landsat imagery and the } \\
\text { double observer (front-back) quadrat procedure (Jan. } \\
\text { 25-31, 1982). }\end{array}$ \\
\hline
\end{tabular}

Cook, A.R.

1982 Stratified random deer census of wildlife management units P208, P210, and P220 using landsat imagery and the double observer (front-back) quadrat procedure.

Cook, A.R. and Dielman, P. $1980 \quad$ Aerial moose survey of WMU M510, December 19 and 19, 1979.

Cook, A.R. and Froggatt, K.

Antelope acrial survey and population analysis.

Cook, A.R. and Hall, B.
1976
Journal / Conference / Etc.

Alberta Fish and Wildlife Division, Edmonton. Unpublished report.

Alberta Fish and Wildlife Division, Edmonton. Unpublished report.

Alberta Fish and Wildlife Division, Edmonton. Unpublished report.

Alberta Fish and Wildlife Division, Edmonton. Unpublished report.

Alberta Fish and Wildlife Division, Edmonton. Unpublished report.

Alberta Fish and Wildlife Division, Edmonton. Unpublished report.

Alberta Fish and Wildlife Division, Edmonton. Unpublished report.

Alberta Fish and Wildlife Division, Edmonton. Unpublished report.

Alberta Fish and Wildlife Division, Edmonton. Unpublished report.

Alberta Fish and Wildlife Division, Edmonton. Unpublished report.

Alberta Fish and Wildlife Division, Edmonton. Unpublished report.

Alberta Fish and Wildlife Division, Edmonton. Unpublished report.

Alberta Fish and Wildlife Division, Edmonton. Unpublished report.

Alberta Fish and Wildlife Division, Edmonton. Unpublished report.

Alberta Fish and Wildlife Division, Edmonton. Unpublished report.

Alberta Fish and Wildlife Division, Edmonton. Unpublished report.

Alberta Fish and Wildlife Division, Edmonton. Unpublished report.

Alberta Fish and Wildlife Division, Edmonton. Unpublished report.

Alberta Fish and Wildlife Division, Edmonton. Unpublished report.

Alberta Fish and Wildlife Division, Edmonton. Unpublished report.

Alberta Fish and Wildlife Division, Edmonton. Unpublished report.

Alberta Fish and Wildlife Division, Edmonton. Unpublished report.

Alberta Fish and Wildlife Division, Edmonton. Unpublished report.

Alberta Fish and Wildlife Division, Edmonton. Unpublished report.

Alberta Fish and Wildlife Division, Edmonton. Unpublished report. 


\begin{tabular}{|c|c|c|}
\hline Author(s) / Editor & Date & Title \\
\hline Cook, A.R. and Hall, B. & 1976 & Region II sheep survey. \\
\hline Cook, A.R. and Hall, B. & 1976 & Ya-Ha-Tinda elk survey (prehunt). \\
\hline Cook, A.R. and Hall, B. & 1977 & Region I prairie deer survey. \\
\hline Cook, A.R. and Hall, B. & 1977 & Sounding Lake deer survey (January 19, 20, 1977). \\
\hline Cook, A.R. and Hall, B. & 1978 & Aerial goat survey of the Kananaskis area. \\
\hline Cook, A.R. and Hall, B. & 1978 & $\begin{array}{l}\text { Antelope aerial survey and population analysis, July } \\
19-24,1978 \text {. }\end{array}$ \\
\hline
\end{tabular}

Cook, A.R., Froggatt, K. and Hall, 1976 Red Deer regional sheep survey.

B.

Cook, A.R., Froggatt, K. and Hall, 1977 B.

\section{Dickinson, D.M.}

Dielman, $\mathrm{P}$.

Dielman, $\mathrm{P}$.

1980 Red Deer River deer survey, February 22,23,24, 1980.

Dielman, P., Froggatt, K. and Cook, A.R.

Edmonds, J.

1979 Wabasca Lakes aerial caribou survey (March 5-7, 1979).

Edmonds, J.

1981 Caribou calving survey in Willmore Wilderness, Jasper National Park and adjacent portions of British Columbia.

1990 Caribou population survey in north Jasper National Park, Willmore Wilderness Provincial Park and Foothill winter ranges, October - November, 1989.

Erickson, G.

1979 Camp Wainwright deer survey.

Erickson, G.

Erickson, G.

Erickson, G., Hilton, M. and Cole, 1976 D.

Festa-Branchet, $\mathrm{M}$.

Folinsbee, J.

1982 Aerial surveys of ungulates in the Blackfoot area, WMU

Folinsbee, J.

1982 An aerial survey of moose in wildlife management unit

Folinsbee, J.

1982 An aerial survey of ungulates in WMU M508 (Thunder

Folinsbee, J.

1982 An aerial survey of WMU F366, 22 and 24 February,

Folinsbee, J.

Folinsbee, J.

Folinsbee, J.

Folinsbee, J. P242, January 1982. M510, 17-18 February 1982. Lake), 24-26, February 1982. 1982.

Wainwright deer survey (transect lines B-11 through B-31).

Mount Allen Bighom sheep study: Description and analysis of winter observations of ewes; $1985-86$ and analysis of

Aerial survey of ungulates in the Beaverhill Lake area, 2 March, 1983.

Aerial survey of ungulates in the Ministik Lake area, 4 March, 1983.

An aerial survey of ungulates in the Blackfoot area P242, 8 March, 1983.

1984 An aerial survey of ungulates in the Blackfoot area, P242, 16 March, 1984.
Journal / Conference / Etc.

Alberta Fish and Wildlife Division, Edmonton. Unpublished report.

Alberta Fish and Wildlife Division, Edmonton. Unpublished report.

Alberta Fish and Wildlife Division, Edmonton. Unpublished report.

Alberta Fish and Wildlife Division, Edmonton. Unpublished report.

Alberta Fish and Wildlife Division, Edmonton. Unpublished report.

Alberta Fish and Wildlife Division, Edmonton. Unpublished report.

Alberta Fish and Wildlife Division, Edmonton. Unpublished report.

Alberta Fish and Wildlife Division, Edmonton. Unpublished report.

Alberta Fish and Wildlife Division, Edmonton. Unpublished report.

Alberta Fish and Wildlife Division, Edmonton. Unpublished report.

Alberta Fish and Wildlife Division, Edmonton. Unpublished report.

Alberta Fish and Wildlife Division, Edmonton. Unpublished report.

Alberta Fish and Wildlife Division, Edmonton. Unpublished report.

Alberta Fish and Wildlife Division, Edmonton Unpublished report.

Alberta Fish and Wildlife Division, Edmonton. Unpublished report.

Alberta Fish and Wildlife Division, Edmonton. Unpublished report.

Alberta Fish and Wildlife Division, Edmonton. Unpublished report.

Alberta Fish and Wildlife Division, Edmonton. Unpublished report.

Department of Biological Sciences, University of Calgary, Calgary, Alberta.

Alberta Fish and Wildlife Division, Edmonton. Unpublished report.

Alberta Fish and Wildlife Division, Edmonton Unpublished report.

Alberta Fish and Wildlife Division, Edmonton. Unpublished report.

Alberta Fish and Wildlife Division, Edmonton. Unpublished report.

Alberta Fish and Wildlife Division, Edmonton Unpublished report.

Alberta Fish and Wildlife Division, Edmonton Unpublished report.

Alberta Fish and Wildlife Division, Edmonton Unpublished report.

Alberta Fish and Wildlife Division, Edmonton. Unpublished report. 


\begin{tabular}{|c|c|c|c|}
\hline Author(s) / Editor & Date & Title & Journal / Conference / Etc. \\
\hline Folinsbee, J. & 1985 & $\begin{array}{l}\text { An aerial survey of ungulates in the Blackfoot area, P242, } \\
24 \text { February, } 1984 \text {. }\end{array}$ & $\begin{array}{l}\text { Alberta Fish and Wildlife Division, Edmonton. } \\
\text { Unpublished report. }\end{array}$ \\
\hline Folinsbee, J. & 1986 & $\begin{array}{l}\text { An aerial survey of ungulates in the Blackfoot area, WMU } \\
242,30 \text { January } 1986 \text {. }\end{array}$ & $\begin{array}{l}\text { Alberta Fish and Wildlife Division, Edmonton. } \\
\text { Unpublished report. }\end{array}$ \\
\hline Froggart, $\mathrm{K}$. & 1979 & $\begin{array}{l}\text { Aerial survey for bighom sheep on known winter ranges } \\
\text { in the Calgary region. }\end{array}$ & $\begin{array}{l}\text { Alberta Fish and Wildlife Division, Edmonton. } \\
\text { Unpublished report. }\end{array}$ \\
\hline Froggatt, K. & 1976 & Region I elk survey. & $\begin{array}{l}\text { Alberta Fish and Wildlife Division, Edmonton. } \\
\text { Unpublished report. }\end{array}$ \\
\hline Froggatt, $\mathrm{K}$. & 1976 & Region I moose survey. & $\begin{array}{l}\text { Alberta Fish and Wildlife Division, Edmonton. } \\
\text { Unpublished report. }\end{array}$ \\
\hline Froggatt, K. & 1976 & Region II mountain moose survey. & $\begin{array}{l}\text { Alberta Fish and Wildlife Division, Edmonton. } \\
\text { Unpublished report. }\end{array}$ \\
\hline Froggatt, $\mathrm{K}$. & 1978 & $\begin{array}{l}\text { Red Deer River deer survey, February 13,14 and 16, } \\
1978 .\end{array}$ & $\begin{array}{l}\text { Alberta Fish and Wildlife Division, Edmonton. } \\
\text { Unpublished report. }\end{array}$ \\
\hline Froggatt, K. & 1978 & Region I elk survey, March 15 and 16, 1978. & $\begin{array}{l}\text { Alberta Fish and Wildlife Division, Edmonton. } \\
\text { Unpublished report. }\end{array}$ \\
\hline Froggatt, $\mathrm{K}$. & 1978 & $\begin{array}{l}\text { Region I foothills moose survey (January } 19-20 \text { and } \\
\text { February 21, 1978). }\end{array}$ & $\begin{array}{l}\text { Alberta Fish and Wildlife Division, Edmonton. } \\
\text { Unpublished report. }\end{array}$ \\
\hline Froggatt, $\mathrm{K}$. & 1978 & $\begin{array}{l}\text { Region II foothills aerial moose survey (Elbow River and } \\
\text { Sheep River areas). January } 26 \text { - February 3, } 1978 .\end{array}$ & $\begin{array}{l}\text { Alberta Fish and Wildlife Division, Edmonton. } \\
\text { Unpublished report. }\end{array}$ \\
\hline Froggatt, $\mathrm{K}$. & 1979 & $\begin{array}{l}\text { Wandering River - Calling Lake moose survey (January } \\
22,23 \text { and } 25,1979 \text { ). }\end{array}$ & $\begin{array}{l}\text { Alberta Fish and Wildlife Division, Edmonton. } \\
\text { Unpublished report. }\end{array}$ \\
\hline Froggatt, $\mathrm{K}$. & 1980 & $\begin{array}{l}\text { Aerial bighom sheep survey of known winter ranges in } \\
\text { region } 3 \text { (Dec. to Jan., 1979-80). }\end{array}$ & $\begin{array}{l}\text { Alberta Fish and Wildlife Division, Edmonton. } \\
\text { Unpublished report. }\end{array}$ \\
\hline Froggatt, $\mathrm{K}$. & 1980 & $\begin{array}{l}\text { Aerial bighorn sheep survey of known winter ranges in the } \\
\text { Rocky Mountain House area of the eastern slopes region. }\end{array}$ & $\begin{array}{l}\text { Alberta Fish and Wildlife Division, Edmonton. } \\
\text { Unpublished report. }\end{array}$ \\
\hline Froggatt, $\mathrm{K}$. & 1980 & $\begin{array}{l}\text { An experimental aerial spring survey for mountain mule } \\
\text { deer in region III, May } 14-15,1980 \text {. }\end{array}$ & $\begin{array}{l}\text { Alberta Fish and Wildlife Division, Edmonton. } \\
\text { Unpublished report. }\end{array}$ \\
\hline Froggatt, $\mathrm{K}$. & 1980 & Deer classification of WMU P200, December 17-18, 1979. & $\begin{array}{l}\text { Alberta Fish and Wildlife Division, Edmonton. } \\
\text { Unpublished report. }\end{array}$ \\
\hline Froggatt, $\mathrm{K}$. & 1980 & $\begin{array}{l}\text { Expansion of the region II prairie deer survey (preliminary } \\
\text { design and census), February } 20-22,1980 .\end{array}$ & $\begin{array}{l}\text { Alberta Fish and Wildlife Division, Edmonton. } \\
\text { Unpublished report. }\end{array}$ \\
\hline Froggatt, $\mathrm{K}$. & 1981 & $\begin{array}{l}\text { Aerial survey for mountain goats in the Willmore } \\
\text { Wilderness and Whitehorse Creek areas. July 6-10, } 1981 .\end{array}$ & $\begin{array}{l}\text { Alberta Fish and Wildlife Division, Edmonton. } \\
\text { Unpublished report. }\end{array}$ \\
\hline Froggatt, $\mathrm{K}$. & 1981 & $\begin{array}{l}\text { Aerial survey for ungulates in WMU P242 } \\
\text { (Blackfoot-Ministik), January } 8 \text { and } 9,1981 \text {. }\end{array}$ & $\begin{array}{l}\text { Alberta Fish and Wildlife Division, Edmonton. } \\
\text { Unpublished report. }\end{array}$ \\
\hline Froggatt, $\mathrm{K}$. & 1982 & $\begin{array}{l}\text { Aerial bighorn sheep survey of known winter ranges in the } \\
\text { Rocky Mountain House area of the eastem slopes region, } \\
\text { February } 19-22,1982 \text {. }\end{array}$ & $\begin{array}{l}\text { Alberta Fish and Wildlife Division, Edmonton. } \\
\text { Unpublished report. }\end{array}$ \\
\hline Froggatt, $\mathrm{K}$. & 1982 & $\begin{array}{l}\text { Central region prairie deer survey (includes the Red Deer } \\
\text { River deer survey), February 9-15, } 1982 \text {. }\end{array}$ & $\begin{array}{l}\text { Alberta Fish and Wildlife Division, Edmonton. } \\
\text { Unpublished report. }\end{array}$ \\
\hline Froggatt, $\mathrm{K}$. & 1982 & $\begin{array}{l}\text { Fall antelope aerial surveys (pre and post antelope hunting } \\
\text { season) in hunting zone G, October } 19-20 \text { and November } \\
1-2,1982 \text {. }\end{array}$ & $\begin{array}{l}\text { Alberta Fish and Wildlife Division, Edmonton. } \\
\text { Unpublished report. }\end{array}$ \\
\hline Froggatt, $\mathrm{K}$. & 1984 & $\begin{array}{l}\text { Antelope aerial survey and population analysis, central } \\
\text { region, July } 16-18,1984 \text {. }\end{array}$ & $\begin{array}{l}\text { Alberta Fish and Wildlife Division, Edmonton. } \\
\text { Unpublished report. }\end{array}$ \\
\hline Froggatt, $\mathrm{K}$. & 1984 & $\begin{array}{l}\text { Fall antelope aerial surveys in hunting zone } \mathrm{G} \text { (pre and } \\
\text { post antelope hunting season) October } 9-10 \text { and November } \\
8 \text { and } 15,1983 \text {. }\end{array}$ & $\begin{array}{l}\text { Alberta Fish and Wildlife Division, Edmonton. } \\
\text { Unpublished report. }\end{array}$ \\
\hline Froggatt, $\mathrm{K}$. & 1984 & $\begin{array}{l}\text { Foothills mule deer classification survey (F302 and F306), } \\
\text { December 14, } 1982 \text {. }\end{array}$ & $\begin{array}{l}\text { Alberta Fish and Wildlife Division, Edmonton. } \\
\text { Unpublished report. }\end{array}$ \\
\hline Froggatt, $\mathrm{K}$. & 1985 & $\begin{array}{l}\text { Aerial deer density survey of wildlife management units } \\
\text { P208 and P220. Dec. 17-18, } 1984 \text {. }\end{array}$ & $\begin{array}{l}\text { Alberta Fish and Wildlife Division, Edmonton. } \\
\text { Unpublished report. }\end{array}$ \\
\hline Froggatt, $\mathrm{K}$. & 1985 & $\begin{array}{l}\text { Antelope aerial survey and population analysis - central } \\
\text { region. }\end{array}$ & $\begin{array}{l}\text { Alberta Fish and Wildlife Division, Edmonton. } \\
\text { Unpublished report. }\end{array}$ \\
\hline
\end{tabular}




\begin{tabular}{lll}
\hline \multicolumn{1}{c}{ Author(s) / Editor } & Date & \multicolumn{1}{c}{ Title } \\
\hline Froggatt, K. & 1985 & $\begin{array}{l}\text { Battle River deer survey in wildlife management units } \\
\text { P224, P222, P226, P228, P230, P204 and P202 (January } \\
\text { 3-5, 1985). }\end{array}$ \\
Froggatt, K. & 1985 & $\begin{array}{l}\text { Deer density survey in WMU P200, January 23-25, } 1985 . \\
\text { Froggatt, K. }\end{array}$ \\
Froggatt, K. & 1985 & $\begin{array}{l}\text { Wildlife management unit P200 deer classification survey } \\
\text { (Dec. 12-13, 1983). }\end{array}$ \\
Froggatt, K. & 1986 & $\begin{array}{l}\text { A preliminary deer density survey in WMU 166 (Flown: } \\
\text { Feb.20, 1986). }\end{array}$ \\
& 1986 & $\begin{array}{l}\text { Aerial deer density survey in wildlife management unit 226 } \\
\text { (flown November 24-25, 1986). }\end{array}$
\end{tabular}

Froggatt, K.

1986 Pronghom aerial survey and population analysis for the central region (flown July 15 and 20, 1986).

Froggatt, $\mathrm{K}$.

1986 Stratified random deer density survey in wildlife management unit 206 (flown: February 18-19, 1986).

Froggatt, $\mathrm{K}$.

1986 Stratified random deer density survey in wildlife management unit 224 (flown Feb. 21-23, 1986).

Froggatt, $\mathrm{K}$.

1987 Aerial deer density in wildlife management units 151,152 and 164, January 15-17 and 19-20, 1987.

Froggatt, $\mathrm{K}$.

1987 Pronghom antelope aerial survey and population analysis for the central region, (Flown: July 14-15, 1987).

Froggatt, $\mathrm{K}$.

1987 Stratified random deer density survey in wildlife management unit 208 (flown March 9, 10 and 17, 1987).

Froggatt, $\mathrm{K}$.

1987 Stratified random deer density survey in WMU P202 (Jan. 12-14, 1984)

Froggatt, $\mathrm{K}$.

1987 WMU 216 General aerial reconnaissance survey for moose and waterfowl.

Froggatt, K.

1988 Antelope aerial survey and population analysis for the central region (July 19-20, 1988).

Froggatt, $\mathrm{K}$.

1988 Stratified random deer density survey in Wildlife Mgmt. Unit 310 (Mar. 16-17, 1988).

Froggatt, $\mathrm{K}$.

1988 Stratified random deer density survey in WMU 200 (Jan. 7-8, 1988).

Froggatt, $\mathrm{K}$.

1988 Stratified random deer density survey in WMU 204 (Feb. 15-16, 1988).

Froggatt, $\mathrm{K}$.

1988 Stratified random deer density survey in WMU 216 (Mar. 29-30, 1988).

Froggatt, $\mathrm{K}$.

1988 Stratified random deer density survey in WMU 312 (January 12-14 and March 15, 1988).

Froggatt, $\mathrm{K}$.

1989 Antelope aerial survey and population analysis for the central region (Flown: July 18-19, 1989).

Froggatt, K.

1989 Deer density survey in Wildlife Management Unit 160, January 13-14, 1989.

Froggatt, $\mathbf{K}$.

1989 Stratified random deer density and classification survey in WMU 206 (Flown Dec. 14-15, 1988).

Froggatt, $\mathrm{K}$.

1989 Stratified random deer density survey in Wildlife Management Unit 222 (Flown: March 3 and December 22, 1989)

Froggatt, $\mathrm{K}$.

1989 Stratified random deer density survey in WMU 166 (Flown: Dec. 20, 1988 - Jan. 11, 1989).

Froggatt, $\mathrm{K}$.

1989 Stratified Random deer density survey in WMU 314 (Jan.6, 8-9, 1989).

Froggatt, K.

1990 Antelope classification survey and population estimate for central region. (July 17-19, 1990).

Froggatt, K.

1990 Deer density survey in Wildlife Management Unit 151. (Feb.1, 1990)
Journal / Conference / Etc.

Alberta Fish and Wildlife Division, Edmonton. Unpublished report.

Alberta Fish and Wildlife Division, Edmonton. Unpublished report.

Alberta Fish and Wildlife Division, Edmonton. Unpublished report.

Alberta Fish and Wildlife Division, Edmonton. Unpublished report.

Alberta Fish and Wildlife Division, Edmonton. Unpublished report.

Alberta Fish and Wildlife Division, Edmonton. Unpublished report.

Alberta Fish and Wildlife Division, Edmonton. Unpublished report.

Alberta Fish and Wildlife Division, Edmonton. Unpublished report.

Alberta Fish and Wildlife Division, Edmonton. Unpublished report.

Alberta Fish and Wildlife Division, Edmonton. Unpublished report.

Alberta Fish and Wildlife Division, Edmonton. Unpublished report.

Alberta Fish and Wildlife Division, Edmonton. Unpublished report.

Alberta Fish and Wildlife Division, Edmonton. Unpublished report.

Alberta Fish and Wildlife Division, Edmonton. Unpublished report.

Alberta Fish and Wildlife Division, Edmonton. Unpublished report.

Alberta Fish and Wildlife Division, Edmonton. Unpublished report.

Alberta Fish and Wildlife Division, Edmonton. Unpublished report.

Alberta Fish and Wildlife Division, Edmonton. Unpublished report.

Alberta Fish and Wildlife Division, Edmonton. Unpublished report.

Alberta Fish and Wildlife Division, Edmonton. Unpublished report.

Alberta Fish and Wildlife Division, Edmonton. Unpublished report.

Alberta Fish and Wildlife Division, Edmonton. Unpublished report.

Alberta Fish and Wildlife Division, Edmonton. Unpublished report.

Alberta Fish and Wildlife Division, Edmonton. Unpublished report.

Alberta Fish and Wildlife Division, Edmonton. Unpublished report.

Alberta Fish and Wildlife Division, Edmonton. Unpublished report.

Alberta Fish and Wildlife Division, Edmonton. Unpublished report. 


\begin{tabular}{|c|c|c|}
\hline Author(s) / Editor & Date & Title \\
\hline Froggatt, $\mathbf{K}$. & 1990 & $\begin{array}{l}\text { Deer density survey in Wildlife Management Unit } 162 \\
\text { February 13-14, } 1990 .\end{array}$ \\
\hline Froggatt, $\mathrm{K}$. & 1990 & $\begin{array}{l}\text { Deer density survey in Wildlife Management Unit } 164 \\
\text { (February } 15 \text { and March 3-4, 1990). }\end{array}$ \\
\hline Froggatt, $\mathrm{K}$. & 1990 & $\begin{array}{l}\text { Stratified random deer density survey and classification } \\
\text { survey in WMU 208, November 28, } 1989 \text { - February } \\
1990 .\end{array}$ \\
\hline Froggatt, $\mathbf{K}$. & 1990 & $\begin{array}{l}\text { Stratified random deer density survey in Wildlife } \\
\text { Management Unit 202. (Dec. 18, } 1989 \text { - Feb. 26, } 199\end{array}$ \\
\hline Froggatt, $\mathbf{K}$. & 1991 & $\begin{array}{l}\text { Stratified random deer density survey and classification } \\
\text { survey in Wildlife Management Unit 220, December } 3 \\
1990 \text { - January 9, } 1991 \text {. }\end{array}$ \\
\hline Froggatt, $\mathrm{K}$. and Hall, B. & 1975 & Alder Flats-Medicine Lake moose survey. \\
\hline Froggatt, $\mathrm{K}$. and Hall, B. & 1975 & Red Deer River deer survey. \\
\hline Froggatt, $\mathrm{K}$. and Hall, B. & 1975 & Wainwright deer survey. \\
\hline Froggatt, K. and Hall, B. & 1976 & $\begin{array}{l}\text { Aerial moose survey of the Cow, Swan and Burntstick } \\
\text { Lakes and Sundre area, December 13-15, } 1976 .\end{array}$ \\
\hline Froggatt, K. and Hall, B. & 1976 & Region 3 elk survey of known wintering ranges. \\
\hline Froggatt, $\mathrm{K}$. and Hall, B. & 1976 & Region I (drainages) moose survey. \\
\hline Froggatt, K. and Hall, B. & 1976 & Region I elk survey. \\
\hline Froggatt, K. and Hall, B. & 1976 & Region II (drainages) moose survey. \\
\hline Froggatt, K. and Hall, B. & 1976 & WMU F354 aerial moose survey. \\
\hline Froggatt, $\mathrm{K}$. and Hall, B. & 1976 & Ya-Ha-Tinda elk survey (post hunt). \\
\hline Froggatt, K. and Hall, B. & 1977 & $\begin{array}{l}\text { Aerial moose survey of the Smoky River area (WMU } \\
\text { M522). }\end{array}$ \\
\hline Froggatt, $\mathrm{K}$. and Hall, B. & 1977 & Aerial ungulate survey of the Peace River region. \\
\hline Froggatt, $\mathrm{K}$. and Hall, B. & 1977 & Pine Lake deer survey. \\
\hline Froggatt, K. and Hall, B. & 1978 & Region I elk survey. \\
\hline
\end{tabular}

Froggatt, K., Cook, A.R. and Hall, 1976 Antelope aerial survey and population analysis.

Froggatt, K., Cook, A.R. and Hall, 1976 B.

Glasgow, W.

Glasgow, W.

Glasgow, W.

Glasgow, W.

Glasgow, W.

Glasgow, W.
Region I foothills moose survey (quadrats).

Region 7 ungulate survey North Saskatchewan River.

Region 7 ungulate survey WMU P240, P242, Cooking Lake moraine.

Region 7 ungulate survey WMU P242, 248, 250, 260.

Region 7 deer survey WMU's P248, F336, M508, December 13, 1977.

Region 7 moose survey M506, January 18, 1980.

Region 7 ungulate survey WMU P242 December 20, 1976.
Journal / Conference / Etc.

Alberta Fish and Wildlife Division, Edmonton. Unpublished report.

Alberta Fish and Wildlife Division, Edmonton. Unpublished report.

Alberta Fish and Wildlife Division, Edmonton. Unpublished report.

Alberta Fish and Wildlife Division, Edmonton Unpublished report.

Alberta Fish and Wildlife Division, Edmonton. Unpublished report.

Alberta Fish and Wildlife Division, Edmonton. Unpublished report.

Alberta Fish and Wildlife Division, Edmonton. Unpublished report.

Alberta Fish and Wildlife Division, Edmonton. Unpublished report.

Alberta Fish and Wildlife Division, Edmonton. Unpublished report.

Alberta Fish and Wildlife Division, Edmonton. Unpublished report.

Alberta Fish and Wildlife Division, Edmonton. Unpublished report.

Alberta Fish and Wildlife Division, Edmonton. Unpublished report.

Alberta Fish and Wildlife Division, Edmonton. Unpublished report.

Alberta Fish and Wildlife Division, Edmonton. Unpublished report.

Alberta Fish and Wildlife Division, Edmonton. Unpublished report.

Alberta Fish and Wildlife Division, Edmonton. Unpublished report.

Alberta Fish and Wildlife Division, Edmonton. Unpublished report.

Alberta Fish and Wildlife Division, Edmonton. Unpublished report.

Alberta Fish and Wildlife Division, Edmonton. Unpublished report.

Alberta Fish and Wildlife Division, Edmonton. Unpublished report.

Alberta Fish and Wildlife Division, Edmonton. Unpublished report.

Alberta Fish and Wildlife Division, Edmonton. Unpublished report.

Alberta Fish and Wildlife Division, Edmonton. Unpublished report.

Alberta Fish and Wildlife Division, Edmonton. Unpublished report.

Alberta Fish and Wildlife Division, Edmonton. Unpublished report.

Alberta Fish and Wildlife Division, Edmonton. Unpublished report.

Alberta Fish and Wildlife Division, Edmonton. Unpublished report. 


\begin{tabular}{lcl}
\hline \multicolumn{1}{c}{ Author(s) / Editor } & Date & \multicolumn{1}{c}{ Title } \\
\hline Glasgow, W. & 1979 & $\begin{array}{l}\text { Region 7 ungulate survey WMU's P240 and P242 } \\
\text { December 20 and 21, 1977. }\end{array}$ \\
Glasgow, W. & 1979 & $\begin{array}{l}\text { Region 7 ungulate survey WMU's P240 and P242 } \\
\text { December 8 and 12, 1978. }\end{array}$
\end{tabular}

Glasgow, W., and McFetridge, R. 1978

Goski, B.

Goski, B.

Goski, B.

1979 Aerial survey of the McLeod River zone 2, conducted in conjunction with seismic program CV-16-78-G.

Goski, B. and Smith, K.

1979 Aerial survey of Donald's and Chase's Flats.

Goski, B. and Smith, K.

Goski, B. and Smith, K.

Goski, B. and Smith, K.

1979 Aerial survey of the Carrot Creek zone 2 (4-2-11).

Goski, B. and Smith, K.

1979 Aerial survey of the Deep Valley and Simonette River zone 2 (4-2-25), (4-2-26).

Goski, B. and Smith, K.

1979 Aerial survey of the Deer Hill zone 2 (4-2-14).

Goski, B. and Smith, K.

1979 Aerial survey of the Elk River zone 2 (4-2-5).

Goski, B. and Smith, K.

1979 Aerial survey of the McLeod River zone 2 (4-2-10).

Goski, B. and Smith, K.

1979 Aerial survey of the Pembina River zone 2 (4-2-7).

Goski, B. and Smith, K.

1979 Aerial survey of the Tom Hill zone 2 (4-2-15).

Goski, B. and Smith, K.

1979 Aerial survey of the Wildhay River zone 2.

Goski, B., Buchanan, J. and Smith, K.

Gudmundson, L.

1982 Aerial surveys of the Little Smoky River, Prairie Creek, Berland River and Adam's Lookout area.

1977 Region 1 elk survey (March 1977).

Gudmundson, L.

Gudmundson, L.

Gudmundson, L.

Gudmundson, L.

Gudmundson, L.

1984

Gudmundson, L.

Gudmundson, L.

Gudmundson, L.
Journal / Conference / Etc.

Alberta Fish and Wildlife Division, Edmonton. Unpublished report.

Alberta Fish and Wildlife Division, Edmonton. Unpublished report.

Alberta Fish and Wildlife Division, Edmonton. Unpublished report.

Alberta Fish and Wildlife Division, Edmonton. Unpublished report.

Alberta Fish and Wildlife Division, Edmonton Unpublished report.

Alberta Fish and Wildlife Division, Edmonton Unpublished report.

Alberta Fish and Wildlife Division, Edmonton Unpublished report.

Alberta Fish and Wildlife Division, Edmonton. Unpublished report.

Alberta Fish and Wildlife Division, Edmonton. Unpublished report.

Alberta Fish and Wildlife Division, Edmonton. Unpublished report.

Alberta Fish and Wildlife Division, Edmonton. Unpublished report.

Alberta Fish and Wildlife Division, Edmonton. Unpublished report.

Alberta Fish and Wildlife Division, Edmonton. Unpublished report.

Alberta Fish and Wildlife Division, Edmonton. Unpublished report.

Alberta Fish and Wildlife Division, Edmonton. Unpublished report.

Alberta Fish and Wildlife Division, Edmonton. Unpublished report.

Alberta Fish and Wildlife Division, Edmonton. Unpublished report.

Alberta Fish and Wildlife Division, Edmonton. Unpublished report.

Alberta Fish and Wildlife Division, Edmonton. Unpublished report.

Alberta Fish and Wildlife Division, Edmonton. Unpublished report.

Alberta Fish and Wildlife Division, Edmonton. Unpublished report.

Alberta Fish and Wildlife Division, Edmonton. Unpublished report.

Alberta Fish and Wildlife Division, Edmonton. Unpublished report.

Alberta Fish and Wildlife Division, Edmonton. Unpublished report.

Alberta Fish and Wildlife Division, Edmonton. Unpublished report.

Alberta Fish and Wildlife Division, Edmonton. Unpublished report.

Alberta Fish and Wildife Division, Edmonton. Unpublished report. 


Author(s) / Editor
Date Title

Gudmundson, L.

1985

Gudmundson, L.

1985

Gudmundson, L.

1985

Gudmundson, L.

1985

Gudmundson, L.

Gudmundson, L.

Gudmundson, L.

Gudmundson, L.

Gudmundson, L.

Gudmundson, L.

Gudmundson, L.

Gud̀mundson, L.

Gudmundson, L.

Gudmundson, L.

Gudmundson, L.

Gudmundson, L.

Gudmundson, L.

Gudmundson, L.

Gudmundson, L.

Gudmundson, L.

Gudmundson, L.

Gudmundson, L.

Gudmundson, L.

Gudmundson, L.

Gudmundson, L.

Gudmundson, L.

Gudmundson, L.

Gudmundson, L.

1986

1987
Southern region antelope aerial survey and population analysis (July 15-20, 1985).

Southern region antelope aerial survey and population analysis (July 19-23, 1985).

Southern region prairie deer survey (February 8-13, 1985).

Ungulate survey WMU P248, January 7 and 8, 1985.

1985 Wildlife population survey of Cypress Hills Provincial Park and surrounding area.

1985 Wildlife survey report - southern region antelope aerial survey and population analysis (July 15-20, 1985).

1986 1985/86 Southern foothills-mountain elk survey (February, 1986).

1986 Southern continental divide goat survey (Waterton Lakes National Park to Crowsnest Pass).

1986 Southern foothills moose survey (1985-1986).

1987 A reconnaissance survey of sheep wintering areas in the North Livingstone and Cabin Ridge areas.

1987 Southern region antelope aerial survey and population analysis (July 20-22, 1987).

1987 Southern region prairie deer survey (January 14-18, 1987).

1987 Wildlife population surveys of Cypress Hills Provincial Park and surrounding areas.

19881987 Preseason prairie deer classification program (WMU $116,118,119,124,148)$.

19881988 Preseason prairie mule deer classification survey (WMU 116, 118, 119, 148).

1988 Southern continental divide goat survey (Waterton Lakes National Park to Crowsnest Pass).

1988 Southern region antelope aerial survey and population analysis (18-21, July, 1988).

1988 Southern region prairie deer survey (Feb. 9, and 10, 1988).

1988 Wildlife population survey of Cypress Hills Provincial Park and surrounding area.

1989 1988/89 Southem foothill-Mountain elk survey (Feb., 1989).

1989 Southern continental divide goat survey (Waterton Lakes National Park to Crowsnest Pass).

1989 Southern foothills moose survey (1988-89).

1989 Southern region antelope aerial survey and population analysis (July 17-19, 1989).

1989 Southern region prairie deer survey (March 13 and 14, 1990).

1989 Wildlife population survey of Cypress Hills Provincial Park and surrounding area.

$19901989 / 90$ Southern foothills - Mountain Elk Survey (February, 1990).
Journal / Conference / Etc.

Alberta Fish and Wildlife Division, Edmonton. Unpublished report.

Alberta Fish and Wildlife Division, Edmonton. Unpublished report.

Alberta Fish and Wildlife Division, Edmonton. Unpublished report.

Alberta Fish and Wildlife Division, Edmonton. Unpublished report.

Alberta Fish and Wildlife Division, Edmonton. Unpublished report.

Alberta Fish and Wildlife Division, Edmonton. Unpublished report.

Alberta Fish and Wildlife Division, Edmonton. Unpublished report.

Alberta Fish and Wildlife Division, Edmonton. Unpublished report.

Alberta Fish and Wildlife Division, Edmonton. Unpublished report.

Alberta Fish and Wildlife Division, Edmonton. Unpublished report.

Alberta Fish and Wildlife Division, Edmonton. Unpublished report.

Alberta Fish and Wildlife Division, Edmonton. Unpublished report.

Alberta Fish and Wildlife Division, Edmonton. Unpublished report.

Alberta Fish and Wildlife Division, Edmonton. Unpublished report.

Alberta Fish and Wildlife Division, Edmonton. Unpublished report.

Alberta Fish and Wildlife Division, Edmonton. Unpublished report.

Alberta Fish and Wildlife Division, Edmonton. Unpublished report.

Alberta Fish and Wildlife Division, Edmonton. Unpublished report.

Alberta Fish and Wildlife Division, Edmonton. Unpublished report.

Alberta Fish and Wildlife Division, Edmonton. Unpublished report.

Alberta Fish and Wildlife Division, Edmonton. Unpublished report.

Alberta Fish and Wildlife Division, Edmonton. Unpublished report.

Alberta Fish and Wildlife Division, Edmonton. Unpublished report.

Alberta Fish and Wildlife Division, Edmonton. Unpublished report.

Alberta Fish and Wildlife Division, Edmonton. Unpublished report.

Alberta Fish and Wildlife Division, Edmonton. Unpublished report.

Alberta Fish and Wildlife Division, Edmonton. Unpublished report.

Alberta Fish and Wildlife Division, Edmonton. Unpublished report. 


\begin{tabular}{|c|c|c|}
\hline Author(s) / Editor & Date & Title \\
\hline Gudmundson, L. & 1990 & $\begin{array}{l}\text { Southern continental divide goat survey (Waterton Lakes } \\
\text { National Parks to Crowsnest Pass). }\end{array}$ \\
\hline Gudmundson, L. & 1991 & $\begin{array}{l}\text { Wildlife population survey of Cypress Hills Provincial } \\
\text { Park and adjacent areas (1990-91). }\end{array}$ \\
\hline Gudmundson, L.D. & 1975 & $\begin{array}{l}\text { Cypress Hills Provincial Park aerial survey big game } \\
\text { check (April, 1975). }\end{array}$ \\
\hline Gudmundson, L.D. & 1975 & $\begin{array}{l}\text { Wildlife surveys, Cypress Hills Provincial Park, } \\
\text { December, 1975). }\end{array}$ \\
\hline Gudmundson, L.D. & 1975 & $\begin{array}{l}\text { Wildlife surveys, Cypress Hills Provincial Park, Feb. } \\
\text { 1975). }\end{array}$ \\
\hline Gunderson, G. & 1976 & Moose investigations Sand River area WMU 514. \\
\hline Gunderson, G. & 1978 & St. Paul white-tailed deer winter area survey. \\
\hline Gunderson, G. & 1984 & $\begin{array}{l}\text { Camp Wainwright post hunting season deer survey, } \\
\text { December } 19,1984 \text {. }\end{array}$ \\
\hline Gunderson, G. & 1984 & Lakeland area moose survey, March 1-2, 1984. \\
\hline Gunderson, G. & 1984 & WMU M504 moose survey, December 3-4, 1984. \\
\hline Gunderson, G. & 1984 & $\begin{array}{l}\text { WMU P258 and P236 white-tailed deer survey December } \\
5-7,1984 \text {. }\end{array}$ \\
\hline Gunderson, G. & 1985 & $\begin{array}{l}\text { Camp Wainwright post hunting season deer survey, } \\
\text { December } 16,1985 \text {. }\end{array}$ \\
\hline Gunderson, G. & 1985 & $\begin{array}{l}\text { County of Strathcona ungulate survey WMU P248, } \\
\text { January } 7 \text { and } 8,1985 \text {. }\end{array}$ \\
\hline Gunderson, G. & 1985 & Fort McMurray ungulate survey, February 4-8, 1985. \\
\hline Gunderson, G. & 1985 & Lakeland area moose survey, February 13, 15, 19, 1985. \\
\hline Gunderson, G. & 1986 & $\begin{array}{l}\text { Fort McMurray moose survey. WMU } 518 \text { (Feb. 18-20, } \\
\text { 1986). }\end{array}$ \\
\hline Gunderson, G. & 1986 & Moose survey (Jan. 11-13, 1986) \\
\hline Gunderson, G. & 1986 & $\begin{array}{l}\text { Wildlife management unit } 234 \text { deer survey, December } \\
15-17,1986 \text {. }\end{array}$ \\
\hline Gunderson, G. & 1986 & $\begin{array}{l}\text { Wildlife Management Unit } 507 \text { Moose survey, January } 7 \\
\text { and } 8,1986 .\end{array}$ \\
\hline Gunderson, G. & 1986 & $\begin{array}{l}\text { Wildlife management unit } 508 \text { white-tailed deer survey, } \\
\text { Jan. } 6 \text { and } 7,1986 .\end{array}$ \\
\hline Gunderson, G. & 1986 & $\begin{array}{l}\text { Wildlife Management Unit } 509 \text { Moose survey, January } 23 \\
\text { and } 24,1986 .\end{array}$ \\
\hline Gunderson, G. & 1986 & WMU 506 Moose survey (Jan. 22-23, 1986) \\
\hline Gunderson, G. & 1987 & $\begin{array}{l}\text { County of Strathcona ungulate survey WMU } 248 \text {, January } \\
5,1987 \text {. }\end{array}$ \\
\hline Gunderson, G. & 1987 & $\begin{array}{l}\text { Lakeland area moose survey in WMU } 514 \text { (Jan. 28, } 29 \\
\text { and Feb. 23, 1987). }\end{array}$ \\
\hline Gunderson, G. & 1987 & $\begin{array}{l}\text { North Buck - Kerr Lake moose survey in WMU } 504 \\
\text { (Mar. 19, 1987). }\end{array}$ \\
\hline Gunderson, G. & 1988 & $\begin{array}{l}\text { Camp Wainwright deer survey WMU 728-730 (Feb. 22, } \\
\text { 1988). }\end{array}$ \\
\hline Gunderson, G. & 1988 & WMU 238 Deer survey (Jan. 18 and 19, 1988). \\
\hline Gunderson, G. & 1988 & WMU 250 ungulate survey (Feb. 17, 1988). \\
\hline
\end{tabular}

Journal / Conference / Etc.

Alberta Fish and Wildlife Division, Edmonton Unpublished report.

Alberta Fish and Wildlife Division, Edmonton. Unpublished report.

Alberta Fish and Wildlife Division, Edmonton. Unpublished report.

Alberta Fish and Wildlife Division, Edmonton. Unpublished report.

Alberta Fish and Wildlife Division, Edmonton. Unpublished report.

Alberta Fish and Wildlife Division, Edmonton. Unpublished report.

Alberta Fish and Wildlife Division, Edmonton. Unpublished report.

Alberta Fish and Wildlife Division, Edmonton. Unpublished report.

Alberta Fish and Wildlife Division, Edmonton. Unpublished report.

Alberta Fish and Wildlife Division, Edmonton. Unpublished report.

Alberta Fish and Wildlife Division, Edmonton. Unpublished report.

Alberta Fish and Wildlife Division, Edmonton. Unpublished report.

Alberta Fish and Wildlife Division, Edmonton. Unpublished report.

Alberta Fish and Wildlife Division, Edmonton. Unpublished report.

Alberta Fish and Wildlife Division, Edmonton. Unpublished report.

Alberta Fish and Wildlife Division, Edmonton. Unpublished report.

Alberta Fish and Wildlife Division, Edmonton. Unpublished report.

Alberta Fish and Wildlife Division, Edmonton. Unpublished report.

Alberta Fish and Wildlife Division, Edmonton. Unpublished report.

Alberta Fish and Wildlife Division, Edmonton. Unpublished report.

Alberta Fish and Wildlife Division, Edmonton. Unpublished report.

Alberta Fish and Wildlife Division, Ednıonton. Unpublished report.

Alberta Fish and Wildlife Division, Edmonton. Unpublished report.

Alberta Fish and Wildlife Division, Edmonton. Unpublished report.

Alberta Fish and Wildlife Division, Edmonton. Unpublished report.

Alberta Fish and Wildlife Division, Edmonton. Unpublished report.

Alberta Fish and Wildlife Division, Edmonton. Unpublished report.

Alberta Fish and Wildlife Division, Edmonton. Unpublished report. 


\begin{tabular}{lcc}
\hline \multicolumn{1}{c}{ Author(s) / Editor } & Date & Title \\
\hline Gunderson, G. & 1988 & WMU 336 ungulate survey (Feb. 18 and 19, 1988). \\
Gunderson, G. & 1989 & WMU 936 ungulate survey (December 13, 1989). \\
Gunderson, G. & 1990 & WMU 509 ungulate survey, February 14-16, 1990. \\
Gunderson, G. & 1990 & WMU 936 ungulate survey. February 27, 1990. \\
Gunderson, G. & 1991 & Cold Lake air weapons range caribou survey. \\
Gunderson, G. & 1991 & WMU 507 moose survey \\
Gunderson, G. & 1991 & WMU 510 ungulate survey.
\end{tabular}

Gunderson, G. and Rippin, B.

Gunderson, G. and Rippin, B.

Gunderson, G. and Rippin, B.

Gunderson, G. and Rippin, B.

Gunderson, G. and Rippin, B.

Gunderson, G. and Rippin, B.

Gunderson, G. and Rippin, B.

Gunderson, G. and Rippin, B.

Hall, B.

Hall, B. and Bibaud, A.

Hall, B. and Bibaud, A.

Hall, B. and Bibaud, A.

Hall, B. and Bibaud, A.

Hall, B. and Bibaud, A.

Hall, B. and Cook, A.

Hall, B. and Cook, A.

Hall, B. and Cook, A.

Hall, B. and Cook, A.

Hall, B. and Erickson, G.L.

Hall, B. and Froggatt, K.

Hall, B. and Froggatt, K.
1977 Long Lake area moose survey (January 17).

1977 WMU P238 white-tailed deer survey.

1978 Aerial survey of white-tailed deer wintering areas near St. Paul, February 2 and March 9, 1978.

1978 Athabasca River moose survey. March 6, 1978.

1978

Long Lake moose survey (Dec. 12, 1977).

1978 Long Lake moose survey (Nov. 25, 1977).

1978 WMU P236 and P254 aerial deer survey, December 13-20, 1977.

1979

1967

1974

1974

1974

1974

1975

1973

1974

1974

1974

1970

1975

1975
Journal / Conference / Etc.

Alberta Fish and Wildlife Division, Edmonton. Unpublished report.

Alberta Fish and Wildlife Division, Edmonton. Unpublished report.

Alberta Fish and Wildlife Division, Edmonton. Unpublished report.

Alberta Fish and Wildlife Division, Edmonton. Unpublished report.

Alberta Fish and Wildlife Division, Edmonton. Unpublished report.

Alberta Fish and Wildlife Division, Edmonton. Unpublished report.

Alberta Fish and Wildlife Division, Edmonton. Unpublished report.

Alberta Fish and Wildlife Division, Edmonton. Unpublished report.

Alberta Fish and Wildlife Division, Edmonton. Unpublished report.

Alberta Fish and Wildlife Division, Edmonton. Unpublished report.

Alberta Fish and Wildlife Division, Edmonton. Unpublished report.

Alberta Fish and Wildlife Division, Edmonton. Unpublished report.

Alberta Fish and Wildlife Division, Edmonton. Unpublished report.

Alberta Fish and Wildlife Division, Edmonton. Unpublished report.

Alberta Fish and Wildlife Division, Edmonton. Unpublished report.

Alberta Fish and Wildife Division, Edmonton. Unpublished report.

Alberta Fish and Wildlife Division, Edmonton. Unpublished report.

Alberta Fish and Wildlife Division, Edmonton. Unpublished report.

Alberta Fish and Wildlife Division, Edmonton. Unpublished report.

Alberta Fish and Wildlife Division, Edmonton. Unpublished report.

Alberta Fish and Wildlife Division, Edmonton. Unpublished report.

Alberta Fish and Wildlife Division, Edmonton. Unpublished report.

Alberta Fish and Wildlife Division, Edmonton. Unpublished report.

Alberta Fish and Wildlife Division, Edmonton. Unpublished report.

Alberta Fish and Wildlife Division, Edmonton. Unpublished report.

Alberta Fish and Wildlife Division, Edmonton. Unpublished report.

Alberta Fish and Wildlife Division, Edmonton. Unpublished report.

Alberta Fish and Wildlife Division, Edmonton. Unpublished report. 


\begin{tabular}{ccc}
\hline Author(s) / Editor & Date & Title \\
\hline Hall, B. and Ridgeway, P. & $1974 \quad$ Camp Wainwright cattle survey. Alta.
\end{tabular}

Hall, B., Bibaud, A. and Cook, A. 1973

Hall, B., Bibaud, A. and Cook, A. 1974

Hall, B., Bibaud, A., Cook, A. and 1975 Froggatt, K.

Hall, B., Bibaud, A., Nibourg, J. 1975 and Brown, D.

Hall, B., Bibaud, A., Nibourg, J. 1975 and Brown, D.

Hall, B., Cook, A. and Froggatt, 1974 K.

Hall, B., Cook, A. and Froggatt, 1974 K.

Hall, B., Cook, A. and Froggatt, K.

Hall, B., Cook, A. and Gunderson, 1973 G.

Hall, B., Cook, A. and Gunderson, 1973 G.

Hall, B., Cook, A. and Gunderson, 1973 G. Hall, B., Froggatt, K. and Cook, 1975
A.

Hall, B., Froggatt, K. and Cook, 1975 A.

Hall, B., Froggatt, K. and Cook, 1975 A.

Hall, B., Froggatt, K. and Cook, 1975 A.

Hall, B., Gunderson, G. and Cook, 1973 A.

Hall, B., Gunderson, G. and Cook, 1973 A.

Hall, B., Gunderson, G. and Cook, 1974 A.

Hall, B., Gunderson, G. and Cook, 1974 A.

Hall, B., Gunderson, G. and

Erickson, G.

Hall, B., Nibourg, J., Bibaud, A. and Brown, D.

Hall, B., Nibourg, J., Bibaud, A. 1975 and Brown, D.

Hall, B., Nibourg, J., Bibaud, A. and Brown, D.

Hauge, T.M. and Keith, L.B.

Hilton, $\mathbf{M}$.

Holten, G.R.
Willmore Wilderness Park summer goat and sheep survey.

Willmore Wilderness Park summer sheep and goat survey.

Ya-Ha-Tinda elk survey.

Clearwater-High Hill River moose survey (river versus muskeg habitat).

Peerless Lake aerial survey.

Antelope aerial survey and population analysis, 1974.

Wandering River - Calling Lake moose survey.

Aerial moose survey of the Cow, Swan and Burntstick Lakes and Sundre areas.

Antelope aerial survey and population analysis.

Red Deer River deer survey. Alberta.

Ya-Ha-Tinda elk survey.

Calgary region sheep survey.

Region I bighom sheep survey. Alberta.

Region I elk survey.

Sounding Lake deer survey.

Clear Hills wapiti and moose survey.

Red Deer region sheep survey. Alberta.

Big game zone 6 winter elk survey.

Blackfoot grazing lease ungulate survey.

Wainwright deer survey.

Survey of the east half of mapsheet $84 \mathrm{~N}$ and of mapsheet 840 .

Ungulate survey of mapsheet $74 \mathrm{M}, \mathrm{L}$, and 841 and P.

Ungulate survey of the north half of mapsheet 830 , the east half of mapsheet $73 \mathrm{M}$, and west half of $84 \mathrm{~N}$.

A census of moose on the Syncrude lease during early February 1977.

Camp Wainwright spring deer survey, March 2-3, 1983.

Aerial surveys of ungulates along sections of the Peace River, 6 and 7 December, 1984.

Aerial survey of the Caribou Mountains.
Journal / Conference / Etc.

Alberta Fish and Wildlife Division, Edmonton. Unpublished report.

Alberta Fish and Wildlife Division, Edmonton. Unpublished report.

Alberta Fish and Wildlife Division, Edmonton. Unpublished report.

Alberta Fish and Wildlife Division, Edmonton. Unpublished report.

Alberta Fish and Wildlife Division, Edmonton. Unpublished report.

Alberta Fish and Wildlife Division, Edmonton. Unpublished report.

Alberta Fish and Wildlife Division, Edmonton. Unpublished report.

Alberta Fish and Wildlife Division, Edmonton. Unpublished report.

Alberta Fish and Wildlife Division, Edmonton. Unpublished report.

Alberta Fish and Wildlife Division, Edmonton. Unpublished report.

Fish and Wildlife Division, Edmonton. Unpublished report.

Alberta Fish and Wildlife Division, Edmonton. Unpublished report.

Alberta Fish and Wildlife Division, Edmonton. Unpublished report.

Alberta Fish and Wildlife Division, Edmonton. Unpublished report.

Alberta Fish and Wildlife Division, Edmonton. Unpublished report.

Alberta Fish and Wildlife Division, Edmonton. Unpublished report.

Alberta Fish and Wildlife Division, Edmonton. Unpublished report.

Alberta Fish and Wildlife Division, Edmonton. Unpublished report.

Alberta Fish and Wildlife Division, Edmonton. Unpublished report.

Alberta Fish and Wildlife Division, Edmonton. Unpublished report.

Alberta Fish and Wildlife Division, Edmonton. Unpublished report.

Alberta Fish and Wildlife Division, Edmonton. Unpublished report.

Alberta Fish and Wildlife Division, Edmonton. Unpublished report.

Alberta Fish and Wildlife Division, Edmonton. Unpublished report.

Alberta Oil Sands Environmental Research Project, Edmonton. Unpublished report.

Alberta Fish and Wildlife Division, Edmonton. Unpublished report.

Alberta Fish and Wildlife Division, Edmonton. Unpublished report.

Alberta Fish and Wildlife Division, Edmonton. Unpublished report. 


\begin{tabular}{lcl}
\hline \multicolumn{1}{c}{ Author(s) / Editor } & Date & \multicolumn{1}{c}{ Title } \\
\hline $\begin{array}{l}\text { Holten, G.R. } \\
\text { Holten, G.R. }\end{array}$ & 1987 & Aerial survey of WMU 351, January 1987. \\
Holton, G.R. & 1987 & Aerial survey of WMU 356, January 1987. \\
Holton, G.R. & 1986 & $\begin{array}{l}\text { Aerial survey of the north-east portion of WMU 350 } \\
\text { December 1985. }\end{array}$ \\
Holton, G.R. & 1986 & $\begin{array}{l}\text { Aerial survey of the proposed east Peace Integrated } \\
\text { Resource Plan WMU 520 and 528, January 1986. }\end{array}$ \\
Holton, G.R. & 1986 & $\begin{array}{l}\text { Aerial survey of WMU 358 and 359 December } 1985 . \\
\text { Aerial survey of WMU 526 (Dec. 1985). }\end{array}$ \\
& 1986 &
\end{tabular}

Jalkotzy, M., Pall, O. and Bicknell, 1986 J.

Jalkotzy, M., Pall, O. and Carr, 1985

H.D.

Johnson, B.

1991 Aerial ungulate surveys in WMU 354 from 1978 until 1990.

Jorgenson, J.T.

1987 Bighorn sheep survey of the Westcastle - Yarrow Creek area, 21-22 August, 1986 and 24 March, 1987.

Jorgenson, J.T.

1987

Jorgenson, J.T.

1988

Jorgenson, J.T.

1988

Jorgenson, J.T.

1989

Jorgenson, J.T.

1990 Bighom sheep survey of known winter ranges within the $\mathrm{Calgary}$ district of the eastern slopes region.

Kansas, J. and Pall, O.

1984 A summary of the 1983 aerial surveys of the Mount Allan area.

Kansas, J.L. and Pall, O.

1985 The 1983 aerial survey for bighorn sheep on known winter ranges in the Bow drainage of the Eastem Slopes region.

Keillor, R.

1978 Aerial survey of western portions of WMU F-350 and WMU F351 in the Peace River region, January 27 and February 3, 1978

Keillor, $\mathbf{R}$.

Aerial survey of WMU 354, January 1978.

Keillor, $\mathbf{R}$.

Keillor, $\mathbf{R}$.

Keillor, $\mathbf{R}$.

Keillor, R.

Keillor, R.

Keillor, R.

Keillor, R.

Keillor, R.
1978 Saddle Hills aerial ungulate survey WMU F358, T76-78, R7-,10 December 20, 1978.

1978 Snipe Lake quadrat survey WMU F351 December 5, 6 and 7, 1978.

1978 Wapiti quadrat survey Dec. 6, 1977 and January 4, 6 and 7, 1978 .

1979 Aerial ungulate survey of the Peace River from townsite to B.C. border, January 3, 1979.

1979 Aerial ungulate survey of the Peace River, January 5, 1979.

1979 Elmsworth ungulate survey, December 18, 19, 1979.

Reno moose survey, T78-83, R17-19, WMU M526 and WMU M520, January 8 and 9, 1979.

1979 Western Saddle Hills aerial ungulate survey WMU F358, December 17, 18, 1979.
Journal / Conference / Etc.

Alberta Fish and Wildlife Division, Edmonton. Unpublished report.

Alberta Fish and Wildlife Division, Edmonton. Unpublished report.

Alberta Fish and Wildlife Division, Edmonton. Unpublished report.

Alberta Fish and Wildlife Division, Edmonton. Unpublished report.

Alberta Fish and Wildlife Division, Edmonton. Unpublished report.

Alberta Fish and Wildlife Division, Edmonton. Unpublished report.

Alberta Fish and Wildlife Division, Edmonton. Unpublished report.

Alberta Fish and Wildlife Division, Edmonton. Unpublished report.

Alberta Fish and Wildlife Division, Edmonton. Unpublished report.

Alberta Fish and Wildlife Division, Edmonton. Unpublished report.

Alberta Fish and Wildlife Division, Edmonton. Unpublished report.

Alberta Fish and Wildlife Division, Calgary Unpublished Report.

Alberta Fish and Wildlife Division, Calgary. Unpublished Report.

Alberta Fish and Wildlife Division, Calgary. Unpublished Report.

Alberta Fish and Wildlife Division, Edmonton. Unpublished report.

Alberta Fish and Wildlife Division, Edmonton. Unpublished report.

Alberta Fish and Wildlife Division, Edmonton. Unpublished report.

Alberta Fish and Wildlife Division, Edmonton. Unpublished report.

Alberta Fish and Wildlife Division, Edmonton. Unpublished report.

Alberta Fish and Wildlife Division, Edmonton. Unpublished report.

Alberta Fish and Wildlife Division, Edmonton. Unpublished report.

Alberta Fish and Wildlife Division, Edmonton. Unpublished report.

Alberta Fish and Wildlife Division, Edmonton. Unpublished report.

Alberta Fish and Wildlife Division, Edmonton. Unpublished report.

Alberta Fish and Wildlife Division, Edmonton. Unpublished report.

Alberta Fish and Wildlife Division, Edmonton. Unpublished report.

Alberta Fish and Wildlife Division, Edmonton. Unpublished report. 


\begin{tabular}{|c|c|c|}
\hline Author(s) / Editor & Date & Title \\
\hline Keillor, $\mathbf{R}$. & 1980 & $\begin{array}{l}\text { Aerial ungulate survey Bald Mountain area T85-68, R4-8, } \\
\text { WMU F356, December 12, } 1979 .\end{array}$ \\
\hline Keillor, R. & 1980 & $\begin{array}{l}\text { Aerial ungulate survey of townships } 86-88 \text {, ranges } 20-22 \\
\text { west of the Peace River WMU M526, January 14, } 1980 \text {. }\end{array}$ \\
\hline Keillor, $\mathbf{R}$. & 1980 & $\begin{array}{l}\text { Cadotte Lake survey, township } 86 \text {, ranges } 16,17,18 \text {, } \\
\text { March } 11,1980 .\end{array}$ \\
\hline Keillor, $\mathbf{R}$. & 1980 & $\begin{array}{l}\text { Caribou survey of western portion of Caribou Mountains, } \\
\text { January } 21-25,1980 \text {. }\end{array}$ \\
\hline Keillor, $\mathbf{R}$. & 1980 & $\begin{array}{l}\text { Central Saddle Hills aerial ungulate survey WMU F358, } \\
\text { December } 12,18 \text { and } 30,1980 \text {. }\end{array}$ \\
\hline Keillor, $\mathbf{R}$. & 1981 & Aerial survey of north east portion of WMU F351. \\
\hline Keillor, R. & 1981 & $\begin{array}{l}\text { Aerial survey of Peace River downstream from townsite } \\
\text { (east bank only) January } 5,1981 \text {. }\end{array}$ \\
\hline Keillor, R. & 1981 & $\begin{array}{l}\text { Aerial ungulate survey: Jean D'or integrated management } \\
\text { plan. WMU's M528 and M534. }\end{array}$ \\
\hline Keillor, R. & 1981 & $\begin{array}{l}\text { Aerial ungulate survey of the north east portion of WMU } \\
\text { F352. February } 19 \text { and } 20,1981 \text {. }\end{array}$ \\
\hline Keillor, $\mathbf{R}$. & 1981 & $\begin{array}{l}\text { Aerial ungulate survey of the Peace River: B.C. border to } \\
\text { Peace River town WMU M526, F359, M521, January } 23 \text {, } \\
24,1981 \text {. }\end{array}$ \\
\hline Keillor, R. & 1981 & $\begin{array}{l}\text { Boundary Lake survey WMU - M524 and M526, January } \\
1981 .\end{array}$ \\
\hline Keillor, R. & 1981 & $\begin{array}{l}\text { Caribou survey of eastern portion of Caribou Mountains, } \\
\text { January } 29 \text { and February } 2,1981 .\end{array}$ \\
\hline Keillor, R. & 1981 & Caribou survey. WMU M520. \\
\hline
\end{tabular}

Keillor, R.

1982 Aerial survey of northeast portion of WMU F350, February, 1982.

Keillor, R.

1982 Aerial ungulate survey of WMU M521. December 1981, January 1982.

Keillor, R.

1982 Preliminary aerial survey for caribou in the Bistcho Lake area, March 10, 11 and 12, 1982.

Kemp, G.A.

1966 Preliminary survey of big game populations in Blackfoot grazing lease.

Kerr, G.R.

1964

Kerr, G.R.

1965

Kerr, G.R.

1966

Klassen, L. and LeBlanc. R.

1983 Cow Lake moose survey front-back visibility bias, January 24-29, 1983.

Lalonde, E.J.

1972 Sturgeon Lake ungulate survey.

LeBlanc, R.

1983 Elk winter range surveys for the Rocky Mountain House region.

LeBlanc, R. and Bruns, E.

1982 Region 3 elk survey of known winter ranges, February 9 , 16 and $17,1982$.

LeBlanc, R. and Nette, T.

1984 Bighom sheep surveys of known winter range in the Rocky Mountain House District.

Lynch, G.M.

1971 Ungulate population surveys conducted in the Edson region.

Lynch, G.M. and Cook, A.
Journal / Conference / Etc.

Alberta Fish and Wildlife Division, Edmonton. Unpublished report.

Alberta Fish and Wildlife Division, Edmonton. Unpublished report.

Alberta Fish and Wildlife Division, Edmonton. Unpublished report.

Alberta Fish and Wildlife Division, Edmonton. Unpublished report.

Alberta Fish and Wildlife Division, Edmonton. Unpublished report.

Alberta Fish and Wildlife Division, Edmonton. Unpublished report.

Alberta Fish and Wildlife Division, Edmonton. Unpublished report.

Alberta Fish and Wildlife Division, Edmonton. Unpublished report.

Alberta Fish and Wildlife Division, Edmonton. Unpublished report.

Alberta Fish and Wildlife Division, Edmonton. Unpublished report.

Alberta Fish and Wildlife Division, Edmonton. Unpublished report.

Alberta Fish and Wildlife Division, Edmonton. Unpublished report.

Alberta Fish and Wildlife Division, Edmonton. Unpublished report.

Alberta Fish and Wildlife Division, Edmonton. Unpublished report.

Alberta Fish and Wildlife Division, Edmonton. Unpublished report.

Alberta Fish and Wildlife Division, Edmonton. Unpublished report.

Alberta Fish and Wildlife Division, Edmonton. Unpublished report.

Alberta Fish and Wildlife Division, Edmonton. Unpublished report.

Alberta Fish and Wildlife Division, Edmonton. Unpublished report.

Alberta Fish and Wildlife Division, Edmonton. Unpublished report.

Alberta Fish and Wildlife Division, Edmonton. Unpublished report.

Alberta Fish and Wildlife Division, Edmonton. Unpublished report.

Alberta Fish and Wildlife Division, Edmonton. Unpublished report.

Alberta Fish and Wildlife Division, Edmonton. Unpublished report.

Alberta Fish and Wildlife Division, Edmonton. Unpublished report.

Alberta Fish and Wildlife Division, Edmonton. Unpublished report.

Alberta Fish and Wildlife Division, Edmonton. Unpublished report. 


\begin{tabular}{|c|c|c|}
\hline Author(s) / Editor & Date & Title \\
\hline MacCallum, B. & 1978 & $\begin{array}{l}\text { Ungulate survey of the upper Red Deer grazing allotmer } \\
\text { December } 14,1978 \text {. }\end{array}$ \\
\hline MacCallum, B. & 1979 & $\begin{array}{l}\text { Ungulate survey of the Clearwater grazing allotment, } \\
\text { December } 13,1978 \text {. }\end{array}$ \\
\hline MacCallum, B. & 1979 & $\begin{array}{l}\text { Ungulate survey of the upper Red Deer range allotment, } \\
\text { March 5, } 1979 \text {. }\end{array}$ \\
\hline MacCallum, B. & 1980 & $\begin{array}{l}\text { Ungulate survey of the Clearwater grazing allotment, } \\
\text { February } 23,1980 .\end{array}$ \\
\hline MacCallum, B. & 1980 & $\begin{array}{l}\text { Ungulate survey of the Clearwater grazing allotment, } \\
\text { March 5, } 1979 .\end{array}$ \\
\hline MacCallum, B. & 1980 & $\begin{array}{l}\text { Ungulate survey of the upper Red Deer range allotment, } \\
\text { February } 5,1980 .\end{array}$ \\
\hline Mack, T. and Howarth, M. & 1983 & Twin Butte survey. \\
\hline Markham, B. & 1975 & $\begin{array}{l}\text { Sturgeon Lake-Spring Creek ungulate survey of } 1975 \\
\text { including a comparison with the } 1972-73 \text { survey. }\end{array}$ \\
\hline McCourt, K.H. & 1970 & $\begin{array}{l}\text { Bison and moose study on the Peace-Athabasca Delta } \\
\text { progress report August } 15,1970 \text {. }\end{array}$ \\
\hline McFetridge, R.J. & 1979 & WMU M510 moose survey, March 6 and 7, 1979. \\
\hline McFetridge, R.J. & 1980 & $\begin{array}{l}\text { Fort Assiniboine moose survey - } 1979 \text { (F350, M508, } \\
\text { M510). }\end{array}$ \\
\hline McFetridge, R.J. & 1980 & $\begin{array}{l}\text { Fort Assiniboine moose survey - } 1980 \text { (F350, M508, } \\
\text { M510). }\end{array}$ \\
\hline Mentz, E. & 1975 & 1975 Snipe Lake survey. \\
\hline
\end{tabular}

Millar, J.

1951 A wildlife survey of the former Athabasca forest reserve.

Mitchell, G.

1954 Aerial census of big game in the Crowsnest Forest Reserve, Alberta 1954.

Mitchell, G.

19581958 aerial deer survey.

Mitchell, G.

1959 Aerial census of big game south of the Bow River.

Moller, K.

Moller, K.

Moller, K.

Moller, K.

Moller, K.

Moller, K.

Moller, K.

Moller, K.

Moller, K.

Moller, K. and Russell, L.
Journal / Conference / Etc.

Alberta Fish and Wildlife Division, Edmonton. Unpublished report.

Alberta Fish and Wildlife Division, Edmonton. Unpublished report.

Alberta Fish and Wildlife Division, Edmonton. Unpublished report.

Alberta Fish and Wildlife Division, Edmonton. Unpublished report.

Alberta Fish and Wildlife Division, Edmonton. Unpublished report.

Alberta Fish and Wildlife Division, Edmonton. Unpublished report.

Alberta Fish and Wildlife Division, Edmonton. Unpublished report.

Alberta Fish and Wildlife Division, Edmonton. Unpublished report.

Canadian Wildlife Service, Edmonton.

Unpublished report.

Alberta Fish and Wildlife Division, Edmonton. Unpublished report.

Alberta Fish and Wildlife Division, Edmonton. Unpublished report.

Alberta Fish and Wildlife Division, Edmonton. Unpublished report.

Alberta Fish and Wildlife Division, Edmonton. Unpublished report.

Alberta Fish and Wildlife Division, Edmonton. Unpublished report.

Alberta Fish and Wildlife Division, Edmonton. Unpublished report.

Alberta Fish and Wildlife Division, Edmonton. Unpublished report.

Alberta Fish and Wildlife Division, Edmonton. Unpublished report.

Alberta Fish and Wildlife Division, Edmonton. Unpublished report.

Alberta Fish and Wildlife Division, Edmonton. Unpublished report.

Alberta Fish and Wildlife Division, Edmonton. Unpublished report.

Alberta Fish and Wildlife Division, Edmonton. Unpublished report.

Alberta Fish and Wildlife Division, Edmonton. Unpublished report.

Alberta Fish and Wildlife Division, Edmonton. Unpublished report.

Alberta Fish and Wildlife Division, Edmonton. Unpublished report.

Alberta Fish and Wildlife Division, Edmonton. Unpublished report.

Alberta Fish and Wildlife Division, Edmonton. Unpublished report.

Alberta Fish and Wildlife Division, Edmonton. Unpublished report. 


\begin{tabular}{|c|c|c|}
\hline Author(s) / Editor & Date & Title \\
\hline Moller, K. and Russell, L. & 1978 & Quadrat survey of the Clear Hills. December 13-20, 1977 \\
\hline Morgantini, L.E. & 1982 & $\begin{array}{l}\text { Preliminary winter wildlife surveys along the proposed } \\
\text { South Hanlan-Blackstone Creek gas pipeline. }\end{array}$ \\
\hline Moyles, D.L.J. & 1990 & Aerial Survey of Big Game in WMU 351. \\
\hline Moyles, D.L.J. & 1990 & Aerial surveys in WMUs 520 and 528, March 1990. \\
\hline Moyles, D.L.J. & 1990 & $\begin{array}{l}\text { Survey of the Woodland caribou in WMU } 536 \text { - The } \\
\text { "Border Play" Area }\end{array}$ \\
\hline Moyles, D.L.J. & 1991 & Aerial survey for big game in WMU 358, December 1990. \\
\hline Moyles, D.L.J. & 1991 & Aerial survey for moose in WMU 526, January 1991. \\
\hline Moyles, D.L.J. & 1991 & $\begin{array}{l}\text { Woodland caribou aerial survey, Caribou Mountains, } \\
\text { winter 1989-90. }\end{array}$ \\
\hline Nelson, D. & 1983 & $\begin{array}{l}\text { Survey of elk winter range in the Peace River region. } \\
\text { February. }\end{array}$ \\
\hline Nette, R. and LeBlanc, $R$. & 1985 & $\begin{array}{l}\text { Elk winter range survey for the Rocky Mountain House } \\
\text { area, March, } 1985 \text {. }\end{array}$ \\
\hline Nette, $T$. & 1983 & $\begin{array}{l}\text { Elk surveys (summer 1983) of the Rocky Mountain House } \\
\text { area. }\end{array}$ \\
\hline Nette, $T$. & 1984 & $\begin{array}{l}\text { Elk and sheep surveys (summer, 1984) of the Rocky } \\
\text { Mountain House area. }\end{array}$ \\
\hline Nette, $\mathrm{T}$. & 1985 & Elk and summer sheep surveys, 1985. \\
\hline
\end{tabular}

Nette, T.

Nette, T., Patan, D. and Johnson, 1986 P.

Nibourg, J., and Hall, B.

Nieman, G.

Nieman, G.

Nolan, J.W. and Scheffler, E.G.

Nolan, J.W. and Smith, D.

Novak, M.

Novak, M.

Olson, S. and Bruns, E.

Pall, O.

Pall, O.

Pall, O. and Cooper, C.

Pall, O. and Kansas, J.

Pall, O. and Klassen, L. Rocky Mountain House management district.

Cow Lake area moose density survey, December 1985 and February 1986.

Region III mountain moose survey.

Buffalo Lake deer survey.

Battle River deer survey.

A report on the Willmore Wilderness Park aerial surveys, February 18-22, 1969.

Aerial survey of Willmore Wilderness Park and Rock Lake area. January 20 - January 24, 1971.

Results of moose aerial surveys, March, 1967, in the St. Paul region.

Results of moose aerial surveys, January, 1968, in the St. Paul region.

Region 3 - elk survey of known winter ranges. Jan. 21, 1987.

The 1974 foothills moose survey in region II.

1985 summer goat survey.

The 1986 winter elk survey of the east slopes of Alberta Bow to Highwood area (February, 1986). Bow to Highwood area (February/March, 1982).

1981 The 1980 winter elk survey in region II (February, 1981).
Bighorn sheep surveys of known winter ranges within the

The 1982 winter elk survey of the east slopes of Alberta -
Journal / Conference / Etc.

Alberta Fish and Wildlife Division, Edmonton. Unpublished report.

Prepared for Canterra Energy Ltd. Prepared by Wildland Resources Consultants. 29 pp.

Alberta Fish and Wildlife Division, Edmonton. Unpublished report.

Alberta Fish and Wildlife Division, Edmonton. Unpublished report.

Alberta Fish and Wildlife Division, Edmonton. Unpublished report.

Alberta Fish and Wildlife Division, Edmonton. Unpublished report.

Alberta Fish and Wildlife Division, Edmonton. Unpublished report.

Alberta Fish and Wildlife Division, Edmonton. Unpublished report.

Alberta Fish and Wildlife Division, Edmonton. Unpublished report.

Alberta Fish and Wildlife Division, Edmonton. Unpublished report.

Alberta Fish and Wildlife Division, Edmonton. Unpublished report.

Alberta Fish and Wildlife Division, Edmonton. Unpublished report.

Alberta Fish and Wildlife Division, Edmonton. Unpublished report.

Alberta Fish and Wildlife Division, Edmonton. Unpublished report.

Alberta Fish and Wildlife Division, Edmonton. Unpublished report.

Alberta Fish and Wildlife Division, Edmonton. Unpublished report.

Alberta Fish and Wildlife Division, Edmonton. Unpublished report.

Alberta Fish and Wildlife Division, Edmonton. Unpublished report.

Alberta Fish and Wildlife Division, Edmonton. Unpublished report.

Alberta Fish and Wildlife Division, Edmonton. Unpublished report.

Alberta Fish and Wildlife Division, Edmonton. Unpublished report.

Alberta Fish and Wildlife Division, Edmonton. Unpublished report.

Alberta Fish and Wildlife Division, Edmonton. Unpublished report.

Alberta Fish and Wildlife Division, Edmonton. Unpublished report.

Alberta Fish and Wildlife Division, Edmonton. Unpublished report.

Alberta Fish and Wildlife Division, Edmonton. Unpublished report.

Alberta Fish and Wildlife Division, Edmonton. Unpublished report.

Alberta Fish and Wildlife Division, Edmonton. Unpublished report. 


\begin{tabular}{|c|c|c|}
\hline Author(s) / Editor & Date & Title \\
\hline Paulsen, A.C. & 1977 & $\begin{array}{l}\text { Region III elk survey of known winter ranges, March } \\
21-22,1977 \text {. }\end{array}$ \\
\hline Paulsen, A.C. & 1980 & $\begin{array}{l}\text { Aerial ungulate survey - Dickson Dam site and Red Deer } \\
\text { Medicine Hat areas December 9, } 1980 .\end{array}$ \\
\hline Paulsen, A.C. & 1980 & $\begin{array}{l}\text { Region III elk survey of known winter ranges, Dec. 17, } \\
1979 \text {, Jan. } 7,13,14,20,30,1980 .\end{array}$ \\
\hline Paulsen, A.C. and Bruns, E.H. & 1978 & $\begin{array}{l}\text { Region } 3 \text { elk survey of known winter ranges, February } \\
6-14,1978 .\end{array}$ \\
\hline Pelchat, B. & 1980 & Elbow Valley ungulate survey. \\
\hline $\begin{array}{l}\text { Pendergast, B., Horstman, L. and } \\
\text { Dorey, L.R. }\end{array}$ & 1974 & Population surveys of ungulates. Chapter IV. \\
\hline Penner, D.F. & 1980 & Results of winter track-count surveys in the Judy Creek \\
\hline
\end{tabular}

Petherbridge, $\mathrm{V}$.

Quaedvlieg, M., and Gunderson, 1971 Antelope aerial survey and population analysis.

$\mathrm{G}$.

Quaedvlieg, M., Gunderson, G. and Cook, A.

Quaedvlieg, M., Gunderson, G. and Cook, A.

Quaedvlieg, M., Gunderson, G. and Cook, A.

Quaedvlieg, M., Gunderson, G. and Cook, A.

Quaedvlieg, M., Gunderson, G. and Cook, $\mathrm{A}$.

Quaedvlieg, M., Gunderson, G. and Cook, A.

Quaedvlieg, M., Gunderson, G. and Cook, A.

Quaedvlieg, M., Gunderson, G. and Cook, A.

Quaedvlieg, M., Gunderson, G. and Cook, A.

Quaedvlieg, M., Gunderson, G. and Cook, A.

Quaedvlieg, M., Gunderson, G. and Cook, A.

Raine, R. and Pall, O.

Raine, R., Pall, O. and Carr, H.

Rippin, B.

Rippin, B. and Gunderson, G.

Rippin, B. and Gunderson, G.

Rippin, B. and Gunderson, G.

Rippin, B. and Gunderson, G.
1985 Browse survey of southem foothills. Moose range - 1984. 16-18, 1975.

\section{Coal mine area.}

Cold Lake moose and Lac La Biche caribou survey.

Antelope aerial survey and population analysis.

Red Deer survey. Alberta.

Region III moose survey.

Region IV moose survey.

Swan Hills moose survey.

Wainwright deer survey.

Whitecourt-Edson moose survey.

Battle River and Sounding Lake deer survey.

Region II deer survey (Red Deer River).

Willmore-McIntyre Porcupine coal lease survey - 1973.

1985 Results of the February and March, 1985 aerial ungulate surveys of the Mount Allan area.

The 1984-1985 winter ground surveys of ungulates in the Mount Allan area.

1976 estimate of white-tailed deer in WMU P238 based on a stratification of habitat quality.

Cold Lake - Bonnyville ungulate survey (deer).

Lac La Biche - Goodwin Lake moose survey, January

1975 St. Paul region WMU P258 - deer survey.
Journal / Conference / Etc.

Alberta Fish and Wildlife Division, Edmonton. Unpublished report.

Alberta Fish and Wildlife Division, Edmonton. Unpublished report.

Alberta Fish and Wildlife Division, Edmonton. Unpublished report.

Alberta Fish and Wildlife Division, Edmonton. Unpublished report.

Alberta Fish and Wildlife Division, Edmonton. Unpublished report.

In: Surveys of mammals along proposed gas pipeline in Alberta. Arctic Gas Biological Report Series, Volume 25. Jakimchuk, R.D. (ed.).

Edmonton.

Prepared for Esso Minerals Canada; prepared by McCourt Management Ltd., Calgary. Unpublished report.

Alberta Fish and Wildlife Division, Edmonton. Unpublished report.

Alberta Fish and Wildlife Division, Edmonton Unpublished report.

Alberta Fish and Wildlife Division, Edmonton Unpublished report.

Alberta Fish and Wildlife Division, Edmonton. Unpublished report.

Alberta Fish and Wildlife Division, Edmonton Unpublished report

Alberta Fish and Wildlife Division, Edmonton. Unpublished report

Alberta Fish and Wildlife Division, Edmonton. Unpublished report.

Alberta Fish and Wildlife Division, Edmonton Unpublished report.

Alberta Fish and Wildlife Division, Edmonton Unpublished report.

Alberta Fish and Wildlife Division, Edmonton. Unpublished report.

Alberta Fish and Wildlife Division, Edmonton Unpublished report.

Alberta Fish and Wildlife Division, Edmonton Unpublished report.

Alberta Fish and Wildlife Division, Edmonton. Unpublished report.

Alberta Fish and Wildlife Division, Edmonton Unpublished report.

Alberta Fish and Wildlife Division, Edmonton. Unpublished report

Alberta Fish and Wildlife Division, Edmonton. Unpublished report.

Alberta Fish and Wildlife Division, Edmonton. Unpublished report.

Alberta Fish and Wildlife Division, Edmonton Unpublished report.

Alberta Fish and Wildlife Division, Edmonton Unpublished report.

Alberta Fish and Wildlife Division, Edmonton. Unpublished report. 


\begin{tabular}{|c|c|c|}
\hline Author(s) / Editor & Date & Title \\
\hline Rippin, B. and Gunderson, G. & 1975 & WMU 514 moose survey. \\
\hline Rippin, B. and Gunderson, G. & 1975 & Wolf Lake - Cold Lake ungulate survey. \\
\hline Roe, N.A. & 1982 & $\begin{array}{l}1982 \text { winter ungulate investigations the Alaska Highway } \\
\text { gas pipeline project northern leg (Alberta zone 5). }\end{array}$ \\
\hline
\end{tabular}

Roe, N.A.

1984 Wildlife survey of Dome Petroleum Limited's Primrose Lake lease, February 25, 1984.

Rosin, J.

WMU F356 ungulate survey, January 1984.

Russell, L.

1975 Big game census Whitemud land use assignment committee study area February 20 and 24, 1975.

Russell, L.

Russell, L.

1977 Progress report - wildlife surveys within the Procter and Gamble agreement area.

Salter, R.E. and Koski, W.R.

1979 Studies of ungulates on the Cold Lake lease of Esso Resources Canada Ltd., February 1978 - March, 1979.

Sandilands, K.M.

1956 A report on a biological survey of the area south from the Whitecourt-Grande Prairie highway.

Schowalter, D.B.

1975 Observations of deer and other wildlife during night-lighting: 1975.

Smith, K.

1982 Aerial survey of elk winter ranges in big game zones 5, 6 and 7 (January-March, 1982).

Smith, K.

1984 Aerial survey of wildlife management unit F339 (Jan. 17, 18 and 20,1984 ).

Smith, K.

1985 Annual report of survey/management activities for Mountain goats. Edson wildlife management area. (July 1985).

Smith, K.

1985 Caribou rutting survey west of Grande Cache, Alberta, October, 1985.

Smith, K.

1986 Aerial survey of moose in southern portion of WMU 350 (1986).

Smith, K.

1986 Aerial survey of the Shiningbank "Buck for Wildlife" study area - March 9-11, 1986.

Smith, K.

1986 Aerial survey of wildlife management 337 (March 6,8 and 9, 1986).

Smith. K.

1986 Annual report of survey/management activities for Mountain Goats. (Edson wildlife management area). (July, 1986).

Smith, K., and Edmonds, J.

1987 Annual report of survey/management activities for Mountain Goats, Edson wildlife management area (July, 1987).

Smith, K., and Edmonds, J.

1987 Mountain elk survey big game zone 4 of the Edson sub-region (Feb.- Mar., 1987).

Smith, K., and Edmonds, J.

1987 WMU 344 Aerial moose survey, Feb. 27 and March 9,10, and $12,1987$.

Smith, K. and Edmonds, J.

1989 WMU 339 habitat stratified moose survey, February, 1989.

Smith, K. and Edmonds, J.

1990 Annual report of survey/management activities for Mountain Goats, Edson Wildlife Management Area June and July, 1989.

Smith, K. and Goski, B.

1978 Observations during a wildlife survey of Willmore Wilderness Park September 26 - October 4, 1974.
Journal / Conference / Etc.

Alberta Fish and Wildlife Division, Edmonton. Unpublished report.

Alberta Fish and Wildlife Division, Edmonton. Unpublished report.

Prepared for Foothills Pipe Lines (Yukon) Ltd.; prepared by Environmental Management

Associates, Calgary. Unpublished report.

Prepared for Dome Petroleum Ltd.; prepared by Environmental Management Associates, Calgary. Unpublished report.

Alberta Fish and Wildlife Division, Edmonton. Unpublished report.

Alberta Fish and Wildlife Division, Edmonton. Unpublished report.

Alberta Fish and Wildlife Division, Edmonton. Unpublished report.

Alberta Fish and Wildlife Division, Edmonton. Unpublished report.

Prepared for Esso Resources Canada Ltd.; prepared by LGL Lid., Edmonton. Unpublished report.

Alberta Fish and Wildlife Division, Edmonton. Unpublished report.

Alberta Fish and Wildlife Division, Edmonton. Unpublished report.

Alberta Fish and Wildlife Division, Edmonton. Unpublished report.

Alberta Fish and Wildlife Division, Edmonton. Unpublished report.

Alberta Fish and Wildlife Division, Edmonton. Unpublished report.

Alberta Fish and Wildlife Division, Edmonton. Unpublished report.

Alberta Fish and Wildlife Division, Edmonton. Unpublished report.

Alberta Fish and Wildlife Division, Edmonton. Unpublished report.

Alberta Fish and Wildlife Division, Edmonton. Unpublished report.

Alberta Fish and Wildlife Division, Edmonton. Unpublished report.

Alberta Fish and Wildlife Division, Edmonton. Unpublished report.

Alberta Fish and Wildlife Division, Edmonton. Unpublished report.

Alberta Fish and Wildlife Division, Edmonton. Unpublished report.

Alberta Fish and Wildlife Division, Edmonton. Unpublished report.

Alberta Fish and Wildlife Division, Edmonton. Unpublished report.

Alberta Fish and Wildlife Division, Edmonton. Unpublished report. 


\begin{tabular}{|c|c|c|}
\hline Author(s) / Editor & Date & Title \\
\hline Smith, K. and Goski, B. & 1979 & Aerial survey of the Wildhay River zone 2 (4-2-13). \\
\hline Smith, K. and Hobson, D. & 1990 & $\begin{array}{l}\text { Annual report of survey/management activities for } \\
\text { Mountain Goats, Edson Wildlife Management Area, Ju } \\
\text { and July, } 1990 \text {. }\end{array}$ \\
\hline Smith, K. and Taggart, J. & 1984 & $\begin{array}{l}\text { Annual report of survey/management for mountain goat } \\
\text { Edson area, July } 1984 \text {. }\end{array}$ \\
\hline Smith, $\mathbf{K}$. and Wingert, $\mathrm{K}$. & 1983 & Elk calving survey. Edson subregion (June, 1983). \\
\hline $\begin{array}{l}\text { Smith, K., Behling, W. and } \\
\text { Myrhohm, C. }\end{array}$ & 1985 & $\begin{array}{l}\text { Summer post-calving elk survey progress report, July } \\
1984 \text {. }\end{array}$ \\
\hline $\begin{array}{l}\text { Smith, K., Edmonds, J. and } \\
\text { Stelfox, H. }\end{array}$ & 1987 & $\begin{array}{l}\text { WMU } 332 \text { habitat stratified moose survey, February, } \\
1987 .\end{array}$ \\
\hline $\begin{array}{l}\text { Smith, K., Hobson, D. and } \\
\text { Edmonds, J. }\end{array}$ & 1990 & W.M.U. 338 moose survey, January 1990. \\
\hline
\end{tabular}

Smith, K., Kjeldsen, C. and Hobson, D.

1990 W.M.U. 340 habitat stratified moose survey, February, 1990.

Stegenga, L. and Jorgenson, J. 1987 The 1987 winter elk survey of the east slopes of Alberta; Bow to Highwood area (big game zone 5), March, 1987.

Stelfox, J.G.

1957 Aerial big game transects from the Brazeau River north to the Edmonton-Jasper highway and west of the Saskatchewan and Pembina rivers.

Stelfox, J.G.

1960 Big game survey. Muskeg River west to headwaters of Sheep Creek (Athabasca special area).

Stelfox, J.G.

Stelfox, J.G.

Stelfox, J.G.

Story, B. and Hall, B.

Story, B., Cook, A.R. and Hall, B. 1976

Story, B., Froggatt, K. and Hall, 1976 B.

Story, B., Froggatt, K. and Hall, 1976 B.

Taggart, J.

1984

Taggart, J. and Smith, K.

1983 Aerial survey for mountain goats in the Willmore

Taggart, J. and Smith, K.

Taggart, J. and Smith, K.

Taggant, J. and Smith, K.

Taggart, J. and Wingert, $\mathrm{K}$.

Treichel, B.

Treichel, B. and Hall, B.

Treichel, B. and Hall, B.
Wilderness and Whitehorse Creek area, July 4-9, 1983.

Big game aerial survey zones 12, 13, 14, 16, 1960-1961.

Big game reproduction in the Athabasca special area.

Big game survey, Athabasca special area.

Pine Lake deer survey.

Battle River deer survey.

Pelican Portage - House River moose survey.

Stettler deer survey.

Aerial surveys of elk winter ranges in big game zones 5, 6 and 7. December, 1983 - April, 1984. and 15 (March, 1983).

1984 late winter caribou survey Adams Ridge, Hendrickson Creek and Berland River March 30, 1984.

F342 moose survey for the Coal Branch integrated management plan December 19, 20 and 21, 1983.

Wildlife management unit F350 aerial survey report,

Aerial ungulate survey of Kinuso reforestation project, December 15, 1979, and January 21, 1980.

Prairie deer survey.

1977 March 12, 1983.
Journal / Conference / Etc.

Alberta Fish and Wildlife Division, Edmonton. Unpublished report.

Alberta Fish and Wildlife Division, Edmonton. Unpublished report.

Alberta Fish and Wildlife Division, Edmonton. Unpublished report.

Alberta Fish and Wildlife Division, Edmonton. Unpublished report.

Alberta Fish and Wildlife Division, Edmonton. Unpublished report.

Alberta Fish and Wildlife Division, Edmonton. Unpublished report.

Alberta Fish and Wildlife Division, Edmonton. Unpublished report.

Alberta Fish and Wildlife Division, Edmonton. Unpublished report.

Alberta Fish and Wildlife Division, Edmonton. Unpublished report.

Alberta Fish and Wildlife Division, Edmonton. Unpublished report.

Alberta Fish and Wildlife Division, Edmonton. Unpublished report.

Alberta Fish and Wildlife Division, Edmonton. Unpublished report.

Alberta Fish and Wildlife Division, Edmonton. Unpublished report.

Alberta Fish and Wildlife Division, Edmonton. Unpublished report.

Alberta Fish and Wildlife Division, Edmonton. Unpublished report.

Alberta Fish and Wildlife Division, Edmonton. Unpublished report.

Alberta Fish and Wildlife Division, Edmonton. Unpublished report.

Alberta Fish and Wildlife Division, Edmonton. Unpublished report.

Alberta Fish and Wildlife Division, Edmonton. Unpublished report.

Alberta Fish and Wildlife Division, Edmonton. Unpublished report.

Alberta Fish and Wildlife Division, Edmonton. Unpublished report.

Alberta Fish and Wildlife Division, Edmonton. Unpublished report.

Alberta Fish and Wildlife Division, Edmonton. Unpublished report.

Alberta Fish and Wildlife Division, Edmonton. Unpublished report.

Alberta Fish and Wildlife Division, Edmonton. Unpublished report.

Alberta Fish and Wildlife Division, Edmonton. Unpublished report.

Alberta Fish and Wildlife Division, Edmonton. Unpublished report. 


\begin{tabular}{|c|c|c|}
\hline Author(s) / Editor & Date & Title \\
\hline Treichel, B. and Hall, B. & 1977 & Wandering River - Calling Lake moose survey. \\
\hline Treichel, B. and Hall, B. & 1977 & WMU M510 moose survey. \\
\hline Webb, R. & 1956 & $\begin{array}{l}\text { Winter big game survey, Bow-Clearwater study area, } \\
\text { March-April, } 1956 .\end{array}$ \\
\hline Webb, R. & 1958 & $\begin{array}{l}\text { Game survey, parklands deer survey, January-February - } \\
1958 \text {. }\end{array}$ \\
\hline Webb, R. & 1963 & Antelope aerial survey. \\
\hline Webb, R. & 1964 & Antelope aerial survey. \\
\hline Webb, R. & 1966 & Elk and deer fall and winter aerial surveys. \\
\hline Webb, R. & 1966 & Moose aerial survey. \\
\hline Webb, R. & 1966 & Prairie deer aerial survey. \\
\hline Webb, R. & 1968 & Antelope aerial survey. \\
\hline Westworth, D.A. & 1980 & $\begin{array}{l}\text { Surveys of moose populations in the vicinity of the } \\
\text { Syncrude development, winter } 1979-80 \text {. }\end{array}$ \\
\hline Westworth, D.A. & 1985 & Wildlife population surveys in the Constar study area. \\
\hline $\begin{array}{l}\text { Westworth, D.A. and Brusnyk, } \\
\text { L.M. }\end{array}$ & 1982 & $\begin{array}{l}\text { Wildlife resources of the Constar leases. Section 5; } \\
\text { ungulates. }\end{array}$ \\
\hline $\begin{array}{l}\text { Westworth, D.A. and Brusnyk, } \\
\text { L.M. }\end{array}$ & 1983 & $\begin{array}{l}\text { A wildlife inventory and habitat evaluation of the Genesee } \\
\text { project area. }\end{array}$ \\
\hline Wingert, $\mathrm{K}$. & 1974 & Brazeau Reservoir land use assignment ungulate survey. \\
\hline Wingert, $\mathrm{K}$. & 1974 & Spring Creek ungulate survey. \\
\hline Wingert, $\mathrm{K}$. & 1976 & Spring Creek ungulate survey April 16, 1975. \\
\hline Wingert, $\mathrm{K}$. & 1976 & Spring Creek ungulate survey April 5, 1976. \\
\hline Wingert, $\mathrm{K}$. & 1976 & Sturgeon Lake - Spring Creek ungulate survey. \\
\hline Wingert, $\mathrm{K}$. & 1977 & Sturgeon Lake - Spring Creek ungulate survey. \\
\hline Wingert, $\mathrm{K}$. & 1983 & $\begin{array}{l}\text { Aerial survey of the Shiningbank "Buck for Wildlife" } \\
\text { project area WMU F346, January } 23,24,25 \text { and } 26 \text {, } \\
1984 \text {. }\end{array}$ \\
\hline Wingert, $\mathrm{K}$. & 1983 & F342 aerial survey, March 9, 1983. \\
\hline
\end{tabular}

Wingert, K. and Markham, B.J. 1974 Fawcett Lake-Moose Portage and Rochester ungulate surveys.

Wingert, K. and Smith, K.

1983 Wildlife management unit F352 aerial survey, March 11, 1983.

Wishart, W. and Erickson, G.

1973 Provincial antelope aerial surveys and population estimates for Suffield Experimental Station, 1967-70.

Wishart, W. and Erickson, G. 1973 Wainwright deer survey.
Journal / Conference / Etc.

Alberta Fish and Wildlife Division, Edmonton. Unpublished report.

Alberta Fish and Wildlife Division, Edmonton. Unpublished report.

Alberta Fish and Wildlife Division, Edmonton. Unpublished report.

Alberta Fish and Wildlife Division, Edmonton. Unpublished report.

Alberta Fish and Wildlife Division, Edmonton. Unpublished report.

Alberta Fish and Wildlife Division, Edmonton. Unpublished report.

Alberta Fish and Wildlife Division, Edmonton. Unpublished report.

Alberta Fish and Wildlife Division, Edmonton. Unpublished report.

Alberta Fish and Wildlife Division, Edmonton. Unpublished report.

Alberta Fish and Wildlife Division, Edmonton. Unpublished report.

Prepared for Syncrude Canada Ltd.; prepared by D.A. Westworth and Associates Ltd., Edmonton Unpublished report.

Prepared for Constar Oil Sands Ltd.; prepared by D.A. Westworth and Associates Ltd., Edmonton. Unpublished report.

Prepared for Constar Oil Sand Ltd., prepared by Westworth, D.A. and Associates Ltd.,

Edmonton. Unpublished report.

Prepared for Fording Coal Ltd., prepared by D.A. Westworth and Associated Ltd., Edmonton.

Unpublished report.

Alberta Fish and Wildlife Division, Edmonton. Unpublished report.

Alberta Fish and Wildlife Division, Edmonton. Unpublished report.

Alberta Fish and Wildlife Division, Edmonton. Unpublished report.

Alberta Fish and Wildlife Division, Edmonton. Unpublished report.

Alberta Fish and Wildlife Division, Edmonton. Unpublished report.

Alberta Fish and Wildlife Division, Edmonton. Unpublished report.

Alberta Fish and Wildlife Division, Edmonton. Unpublished report.

Alberta Fish and Wildlife Division, Edmonton. Unpublished report.

Alberta Fish and Wildlife Division, Edmonton. Unpublished report.

Alberta Fish and Wildlife Division, Edmonton. Unpublished report.

Alberta Fish and Wildlife Division, Edmonton. Unpublished report.

Alberta Fish and Wildlife Division, Edmonton. Unpublished report. 
Provincial Ungulate Surveys

Author(s) / Editor

Young, D.A., Weber, M.A. and Fudge, S.M.

Title

1982

Investigations of ungulates distribution winter, 1981-1982 Battle River - Gwynne Reservoir.
Journal / Conference / Etc.

Prepared for Alberta Environment, Planning Division, Edmonton; prepared by Environmental Management Associates, Calgary. Unpublished report. 
Provisioning Programs

\begin{tabular}{lclll}
\hline \multicolumn{1}{c}{ Author(s) / Editor } & Date & \multicolumn{1}{c}{ Title } & Journal / Conference / Etc. \\
\hline Anonymous. & 1986 & $\begin{array}{l}\text { Report on the Ad Hoc committee on game damage and } \\
\text { supplemental winter feeding. }\end{array}$ & $\begin{array}{l}\text { Western Association of Fish and Wildlife } \\
\text { Agencies. }\end{array}$ \\
Glasgow, W.M. & 1985 & $\begin{array}{l}\text { Evaluation of the winter of 1984/85 deer and elk feeding } \\
\text { program in the central region. }\end{array}$ & $\begin{array}{l}\text { Alberta Fish and Wildlife Division, Edmonton. } \\
\text { Unpublished report. }\end{array}$ \\
Glasgow, W.M., and Russell, L. & 1983 & $\begin{array}{l}\text { Summary report for the June 21-22, 1983 workshop to } \\
\text { examine winter feeding of ungulates in Alberta. }\end{array}$ & Alberta Fish and Wildlife Division, Edmonton. \\
Rippin, B. & 1985 & $\begin{array}{l}\text { Summary of the ungulate winter feeding program - NE } \\
\text { region. }\end{array}$ & $\begin{array}{l}\text { Alberta Fish and Wildlife Division, Edmonton. } \\
\text { Unpublished report. }\end{array}$
\end{tabular}




\begin{tabular}{|c|c|c|}
\hline Author(s) / Editor & Date & Title \\
\hline Blood, D.A. & 1963 & $\begin{array}{l}\text { Structure of confined bison herds with regard to } \\
\text { prevention of excessive inbreeding. }\end{array}$ \\
\hline Blood, D.A. & 1974 & $\begin{array}{l}\text { Variation in reproduction and productivity of an enclosed } \\
\text { herd of moose (Alces alces). }\end{array}$ \\
\hline Bunnell, F.L. & 1982 & $\begin{array}{l}\text { The lambing period of mountain sheep: synthesis, } \\
\text { hypotheses and tests. }\end{array}$ \\
\hline Cooper, S. & 1975 & $\begin{array}{l}\text { Bison natality rate and calf survival studies, fall } 1975 \text {, } \\
\text { Wood Buffalo National Park. }\end{array}$ \\
\hline Eccles, T.R. and Shackleton, D.M. & 1979 & $\begin{array}{l}\text { Recent records of twinning in North American mountain } \\
\text { sheep. }\end{array}$ \\
\hline Edmonds, E.J., and Smith, K. & 1991 & $\begin{array}{l}\text { Mountain caribou calf production and survival, and calving } \\
\text { and summer habitat use in west-central Alberta. }\end{array}$ \\
\hline Edmonds, $\mathbf{J}$. & 1981 & $\begin{array}{l}\text { Caribou calving survey in Willmore Wilderness, Jasper } \\
\text { National Park and adjacent portions of British Columbia. }\end{array}$ \\
\hline $\begin{array}{l}\text { Fargey, P., Hawley, A.W.L. and } \\
\text { Coppock, R.W. }\end{array}$ & 1987 & $\begin{array}{l}\text { Serum testosterone levels in wapiti (Cervus elaphus) bulls } \\
\text { fed phenobarbital. }\end{array}$ \\
\hline Festa-Bianchet, $\mathrm{M}$. & 1987 & Individual reproductive success of bighom sheep ewes. \\
\hline Festa-Bianchet, $\mathbf{M}$. & 1988 & $\begin{array}{l}\text { Age-specific reproduction of bighorn ewes in Alberta, } \\
\text { Canada. }\end{array}$ \\
\hline Festa-Bianchet, $\mathbf{M}$. & 1988 & $\begin{array}{l}\text { Age-specific reproduction of bighorn ewes in Alberta, } \\
\text { Canada. }\end{array}$ \\
\hline Festa-Bianchet, $\mathrm{M}$. & 1989 & $\begin{array}{l}\text { Individual differences, parasites, and the costs of } \\
\text { reproduction for bighorn ewes (Ovis canadensis). }\end{array}$ \\
\hline Flook, D.R. & 1967 & A study of the apparent unequal sex ratio of wapiti. \\
\hline Fuller, W.A. & 1955 & Fertility of bison in Wood Buffalo National Park, Canada. \\
\hline Geist, V. & 1964 & On the rutting behavior of the mountain goat. \\
\hline Geist, V. & 1974 & On the evolution of reproductive potential in moose. \\
\hline Geist, V. & 1981 & $\begin{array}{l}\text { On the reproductive strategies in ungulates and some } \\
\text { problems of adaptation. }\end{array}$ \\
\hline
\end{tabular}

Hall, W.K.

1973 Natality and mortality of white-tailed deer (Odocoileus virginianus dacotensis Goldman and Kellogg) in Camp Wainwright, Alberta.

Horejsi, B.L.

1976 Suckling and feeding behavior in relation to lamb survival in bighom sheep (Ovis canadensis Shaw).

Karsten, P.

1976 A breeding program for registered wood bison (Bison bison athabascae) in captivity.

Kozak, H.M.

1988 The effect of winter nutrition on reproductive performance of farmed wapiti.

Mitchell, G.J.

1967 Minimum breeding age of female pronghorn antelope.

Nietfeld, M.T.

Salmon, R.K.

in Parturition and early mother-young behavior of confined review wapiti.

1988 The application of modem genetics to game ranching

Shackleton, D.M. and Hutton, D.A. 1971

Shoesmith, M.W.

Stelfox, J.G. and Tempany, I.R.

Tempany, I.R. and Cooper, S.
1976

An analysis of the mechanism of brooming in mountain sheep horns.

Twin fetuses in woodland caribou.

Natality and calf survival rates from aerial oblique photography.

1976 Bison natality rate and calf survival studies, winter 1975-1976, Wood Buffalo National Park.
Journal / Conference / Etc.

Canadian Wildlife Service, Edmonton. Unpublished report.

Proceedings of International Congress of Game Biologists, 11, 59-66.

Canadian Journal of Zoology, 60, 1-14.

Parks Canada, Calgary; and Canadian Wildlife Service, Edmonton. Unpublished report.

Journal of Wildlife Management, 43, 974-976.

Abstract from Alberta Chapter of the Wildlife Society, 2nd Annual meeting. March 23 and 24, 1991, Edmonton.

Alberta Fish and Wildlife Division, Edmonton. Unpublished report.

University of Alberta Feeders' Day Report, 66, 97-98.

Ph.D. Thesis. University of Calgary, Calgary.

Journal of Mammalogy, 69, 157-159.

Journal of Mammalogy, 69, 157-160.

Journal of Animal Ecology, 58, 785-796.

Ph.D. Thesis. University of Alberta, Edmonton.

Alaska Science Conference Proceedings, 52-63.

Journal of Mammalogy, 45, 551-468.

Naturaliste Canadien., 101, 527-537.

pp. 111-132. In: Evolution today. Scudder, G.E. and Reveal, J.L. (eds.). Carnegie-Mellon University Press, Pittsburgh, PA.

M.Sc. Thesis. University of Calgary, Calgary. $117 \mathrm{pp}$.

Ph.D. Thesis. University of Calgary, Calgary.

Paper presented to 31 st Conference of International Union of Directors of Zoological Gardens.

M.Sc. Thesis. University of Alberta, Edmonton.

Journal of Mammalogy, 48, 489-490.

Journal of Mammalogy

pp. 104-106. In: Proceedings of 3rd Annual Alberta Game Growers' Association Conference. Renecker, L.A. (eds.). Red Deer, Oct. 23-24, 1987.

Z. Saugetierk., 36, 342-350.

Canadian Field Naturalist, 90, 498-499.

In: Bison research 1976 annual report. Canadian wildlife Service, Edmonton.

Parks Canada, Calgary; Canadian Wildlife Service, Edmonton. Unpublished report. 


\section{Reproduction}

\begin{tabular}{|c|c|c|c|}
\hline Author(s) / Editor & Date & Title & Journal / Conference / Etc. \\
\hline Thompson, R.W. and Turner, J.C. & 1982 & $\begin{array}{l}\text { Temporal geographic variation in the lambing season of } \\
\text { bighorn sheep. }\end{array}$ & Canadian Journal of Zoology, 60, 1781-1793. \\
\hline Vriend, H.G. and Barrett, H.W. & 1978 & Low pronghom recruitment - is it an issue? & $\begin{array}{l}\text { pp. 360-379. In: Proceedings of 8th Biennial } \\
\text { Pronghorn Antelope Workshop. Jasper. }\end{array}$ \\
\hline Wenkoff, $M$. & 1988 & Embryo transfer in wapiti and deer. & $\begin{array}{l}\text { pp. 101-103. In: Proccedings of 3rd Annual } \\
\text { Alberta Game Growers' Association Conference. } \\
\text { Renecker, L.A. (eds.). Red Deer, Oct. 23-24, } \\
\text { 1987. }\end{array}$ \\
\hline $\begin{array}{l}\text { Whitehead, P.E. and McEwan, } \\
\text { E.H. }\end{array}$ & 1980 & $\begin{array}{l}\text { Progesterone levels in peripheral plasma of Rocky } \\
\text { Mountain bighorn ewes (Ovis canadensis) during the } \\
\text { estrus cycle and pregnancy. }\end{array}$ & Canadian Journal of Zoology, 58, 1105-1108. \\
\hline Wishart, W. & 1959 & $\begin{array}{l}\text { Age, weight and pregnancy data of big game in zones } 12 \text {, } \\
13,14,15,17 \text { and } 18 \text { from checking station returns } 1958 \\
\text { and } 1959 .\end{array}$ & $\begin{array}{l}\text { Alberta Fish and Wildlife Division, Edmonton. } \\
\text { Unpublished report. }\end{array}$ \\
\hline Wishart, W.D. & 1980 & Hybrids of white-tailed and mule deer in Alberta. & Journal of Wildlife Management, 61, 716-720. \\
\hline Wishart, W.D. & 1981 & January conception in an elk in Alberta. & Journal of Wildlife Management, 45, 544. \\
\hline Wishart, W.D. & 1984 & Bob's Creek elk progesterone levels. & $\begin{array}{l}\text { Alberta Fish and Wildlife Division, Edmonton. } \\
\text { Unpublished report. }\end{array}$ \\
\hline $\begin{array}{l}\text { Wishart, W.D., Hrudka, F., } \\
\text { Schmutz, S.M., Flood, P.F. }\end{array}$ & 1988 & $\begin{array}{l}\text { Observations on spermatogenesis, sperm phenotype, and } \\
\text { fertility in white-tailed } x \text { mule deer hybrids and a yak } x \\
\text { cow hybrid. }\end{array}$ & $\begin{array}{l}\text { Canadian Journal of Zoology, } 66,1664-1671, \\
1988 .\end{array}$ \\
\hline
\end{tabular}




\begin{tabular}{lcl}
\hline \multicolumn{1}{c}{ Author(s) / Editor } & Date & \multicolumn{1}{c}{ Title } \\
\hline Anonymous. & 1972 & $\begin{array}{l}\text { Carrying capacity of the summer and winter bison } \\
\text { paddocks, Banff National Park. }\end{array}$ \\
Anonymous. & 1978 & $\begin{array}{l}\text { Essential habitat requirements of some selected wildlife } \\
\text { species as related to recommendations for grazing reserve } \\
\text { development. }\end{array}$ \\
Barrett, M.W. & 1978 & $\begin{array}{l}\text { Discussion of the impact of a severe winter on northern } \\
\text { pronghorn ranges. }\end{array}$ \\
Barrett, M.W. & 1980 & $\begin{array}{l}\text { Seasonal habitat associations of pronghorns in Alberta. } \\
\text { S. }\end{array}$
\end{tabular}

Barrett, M.W.

1981 Environmental characteristics and functional significance of pronghom fawn bedding sites in Alberta.

Barrett, M.W.

1982 Ranges, habitat, and mortality of pronghoms at the northern limits of their range.

Barrett, M.W.

1984 Movement, habitat use, and predation on pronghom fawns in Alberta.

Best, D.A., Lynch, G.M. and

Rongstad, O.J.

Bjorge, $\mathbf{R}$.

1977 Annual spring movements of moose to mineral licks in Swan Hills, Alberta.

1984 Winter habitat use by woodland caribou in west central Alberta with implications for management.

Blyth, C.

Bruns, E.H.

Cairns, A.L.

Caims, A.L. and Telfer, E.S.

Carpenter, W.

1970 Locations and description of key winter ranges of the pronghom antelope in Alberta.

Collingwood, L.

1977 Seasonal bison distributions correlated to habitat types in Wood Buffalo National Park, 1976-1977.

Courtney, J.

1974 A report on caribou ecology in the snowbowl area of Jasper National Park. July 15-23, 1974.

Cowan, I. McT.

1947 Range competition between mule deer, bighom sheep ,and elk in Jasper National Park.

Day, R.J.

1972 Stand structure, succession, and use of southern Alberta's Rocky Mountain forest.

Dube, L.A.

1986 A reconnaissance survey of potential deer habitat in WMU's 128 and 132-144, March, 1986.

Edwards, R.Y.

1956 Snow depth and ungulate abundance in mountains of western Canada.

Festa-Bianchet, M.

1986 Seasonal dispersion of overlapping mountain sheep ewe groups.

Festa-Bianchet, M.

1986 Site fidelity and seasonal range use by bighorn rams.

Flook, D.R.

Range relationships of some ungulates native to Banff and Jasper National Parks, Alberta.

Flook, D.R.

1964 Range relationships of some ungulates native to Banff and Jasper National Parks, Alberta.

Frokjer, R.

1976 Moose ecology, Rochester study area.

Gates, C.C. and Hudson, R.J.
Journal / Conference / Etc.

Canadian Wildlife Service, Ottawa, ON. Unpublished Report.

Alberta Fish and Wildlife Division, Edmonton. Unpublished report.

Proceedings of Biennial Pronghom Antelope Workshop, 8, 337-359.

pp. 174-195. In: Proceedings of the Ninth Biennial Pronghom Antelope Workshop. Rio Rico, AZ.

Journal of Wildlife Management, 45, 120-131.

Ph.D. Thesis. University of Alberta, Edmonton.

Joumal of Wildlife Management, 48, 542-550.

Proceedings of North American Moose Conference and Workshop, 13, 215-228.

In: Fish and wildlife relationships in old growth forests. Proceedings of American Institute of Fisheries Research and Biology Symposium. Meehan, W.R., Merrell, R.R. and Hanley, R.A (eds.).

M.Sc. Thesis. University of Alberta, Edmonton.

Joumal of Wildlife Management, 41, 560-571.

Canadian Wildlife Service, Edmonton.

Unpublished report.

Joumal of Wildlife Management, 44, 849-857.

Alberta Fish and Wildlife Division, Edmonton. Unpublished report.

In: Wood Buffalo National Park bison research, 1977 annual report. Stelfox, J.G. (compiler). Canadian Wildlife Service, Edmonton.

Unpublished report.

Canadian Wildlife Service, Edmonton. Unpublished report.

Transaction of North American Wildlife Conference, 12, 223-227.

Ecology, 53, 472-478.

Alberta Fish and Wildlife Division, Edmonton. Unpublished report.

Joumal of Wildlife Management, 20, 159-168.

Joumal of Wildlife Management, 50, 325-330.

Canadian Journal of Zoology, 64, 2126-2132.

Canadian Wildlife Service, Edmonton. Unpublished report.

In: Grazing in terrestrial environments. Blackwells Scientific Publishing, London, UK.

Alberta Fish and Wildlife Division, Edmonton. Unpublished report.

Naturaliste Canadien, 108, 153-166. 


\begin{tabular}{|c|c|c|}
\hline Author(s) / Editor & Date & Title \\
\hline Geist, V. and Petocz, R.G. & 1977 & $\begin{array}{l}\text { Bighom sheep in winter: do rams maximize reproductive } \\
\text { fitness by spatial and habitat segregation from ewes? }\end{array}$ \\
\hline Gray, P. and Bloomfield, M. & 1980 & $\begin{array}{l}\text { Second quarterly report on the Berland - A La Peche } \\
\text { caribou study. }\end{array}$ \\
\hline $\begin{array}{l}\text { Gray, P., Bloomfield, M. and } \\
\text { O'Brien, S. }\end{array}$ & 1980 & $\begin{array}{l}\text { First quarterly report on the Berland - A La Peche caribou } \\
\text { study. }\end{array}$ \\
\hline Holsworth, W.N. & 1959 & $\begin{array}{l}\text { Interactions between moose, elk and buffalo in Elk ,Island } \\
\text { National Park, Alberta. }\end{array}$ \\
\hline Hudson, R.J. & 1976 & Resource division within a community of large herbivores. \\
\hline Hudson, R.J. and Blyth, C.B. & 1986 & Mixed grazing systems of the aspen boreal forest. \\
\hline IEC Beak Consultants Ltd. & 1984 & Species-habitat relationship model for elk. \\
\hline Jacobson, P.C. & 1981 & Borgeau sheep range: preliminary report. \\
\hline Jacques, D.R. & 1976 & $\begin{array}{l}\text { Alpine-subalpine winter wildlife habitat for large ungulates } \\
\text { in the southern Rocky Mountains of Alberta. }\end{array}$ \\
\hline
\end{tabular}

Johnson, J.D.

Johnson, J.D.

Kramer, A.

Kramer, A.

Lee, P.G.

Lynch, G.M. and Morgantini, L.E. 1985

Mair, W.W.

Masters, A.

McCourt, K.H.

McFetridge, R.J.

McFetridge, R.J.

McGillis, J.R., Ward, S. and Stelfox, J.G.

Moller, K

Moller, K.

Moodie, D.W. and Kay, A.

1976

Morgan, R.G.

Morgantini, L.E.

Morgantini, L.E.

(in Ecology, movement and distribution of bighom sheep in press) the Sheep Creek-Dormer River region. canadensis Shaw) on Ram Mountain, Alberta. in the Cypress Hills, Alberta, Canada. moose in northwestern Alberta

Moose-elk relations and competition in Banff National Park.

Ecotype use levels and mountain caribou in Jasper

Bison study Peace-Athabasca Delta area, summer 1970.

Strategy of resource use by mountain goats in Alberta.

Summer use of land systems by large mammals, Bow Summit, 1975. area. and Gamble Agreement area. December 20-21, 1977.
Journal / Conference / Etc.

Canadian Journal of Zoology, 55, 1802-1810.

Alberta Fish and Wildlife Division, Edmonton. Unpublished report.

Alberta Fish and Wildlife Division, Edmonton. Unpublished report.

M.Sc. Thesis. University of British Columbia, Vancouver, BC.

Naturaliste Canadien, 103, 153-167.

pp. 381-383. In: Rangelands; a resource under siege. Proceedings of the 2nd Rangeland Congress. Canberra, Australia.

Prepared for Alberta Fish and Wildlife Division, Edmonton. Unpublished report.

Banff Warden Service. Parks Canada, Calgary. Unpublished report.

pp. 134-146. In: Proceedings of Workshop on Subalpine and Alpine Environments. Victoria, BC, April 28-30, 1976.

Alberta Fish and Wildlife Division, Edmonton. Unpublished report.

M.Sc. Thesis. University of Calgary, Calgary.

Notes on the winter ecology of mule and white-tailed deer

Canadian Field Naturalist, 85, 141-145.

Alberta Fish and Wildlife Division, Technical Bulletin 3. Unpublished report.

M.Sc. Thesis. University of Alberta, Edmonton.

Alces, 20, 61-78. National Park.

Strategy of resource use by mountain goat nursery groups. Valley, Banff National Park - phase II: East Gate to Bow

Ungulate resources in the Kakwa River Copton Ridge

Winter ungulate distribution of three blocks in the Proctor

Canadian Wildlife Service, Ottawa, ON. Unpublished report.

Student project, University of British Columbia, Vancouver, BC.

Canadian Wildlife Service, Edmonton. Unpublished report.

pp. 169-173. In: Proceedings of the 1st International Mountain Goat Symposium. Samuel, W. and Macgregor, W.G. (eds.). Kalispell, MT.

M.Sc. Thesis. University of Alberta, Edmonton Canadian Wildlife Service, Edmonton. Unpublished report.

Alberta Fish and Wildlife Division, Edmonton. Unpublished report.

Alberta Fish and Wildlife Division, Edmonton. Unpublished report.

Plains Anthropologist, 21, 45-52.

Plains Anthropologist, 25, 142-160.

M.Sc. Thesis. University of Alberta, Edmonton.

Prepared for Canterra Energy Ltd., prepared by Wildland Resources Consulting Ltd., Edmonton. Unpublished report. 


\begin{tabular}{ll}
\hline Author(s) / Editor & Date
\end{tabular}

Morgantini, L.E. and Hudson, R.J. 1980

Morgantini, L.E. and Hudson, R.J. 1989

Mussell, D.J.

1982

Nietfeld, M.T., Wilk, J.,

Woolnough, K. and Hoskin, B.

Nowlin, R.A.

1978 Habitat selection and food habits of moose in northeastem Alberta.

Oertli, E.E. and Stelfox, J.G.

1975 Large mammal use of land systems and land types, Bow Valley, Banff National Park, winter 1974-75.

Oertli, E. F., and Stelfox, J.G.

1975 Large mammal use of land systems and land types Bow Valley, Banff National Park, winter 1974-75.

Olsen, C.D.

Pfeiffer, E.W.

(in Critical resources of wapiti in the boreal foothills of prep.) Alberta.

1948 Some factors affecting the winter game ranges of Jasper National Park.

Poll, D.M. and Stelfox, J.G. (eds.) 198

Pringle, W.L.

1971 Bison range study, Peace-Athabasca Delta area, May 21-24, 1971.

Quinlan, R.W., Hunt, W.A., Wilson, $\mathrm{K}$. and Kerr, J.

1990 Habitat requirements of emphasis wildlife species in the Weldwood forest management area.

Rault, D.

Raup, H.M.

1933 Range conditions in the Wood Buffalo Park of westem Canada with notes on the history of the wood bison.

Reid, K.W.

1964 Retardation by bison of aspen-spruce succession.

Renecker, L.A. and Hudson, R.J. 1991

Rippin, B.

Scotter, G.W.

Searing, G.F.

Sikes, S.K.

Smith, D. and Lynch, G.

Smith, D. and Wishart, W.D.

Smith, D., Wishart, W.D. and

Lynch, G.M.

Smith, K.G.

Stelfox, J.G.

Stelfox, J.G.
1972 Carrying capacity of the summer and winter bison paddocks, Banff National Park.

1981 A study of ungulate movement patterns in the Athabasca River Valley, Hinton, Alberta. forests, central Alberta.

Deer habitat in WMU 256 from 1950 to 1980.

1976 Ram Mountain bighom sheep study progress report 1976.

1977 Bighorn ram movement at Cadomin, Alberta (1975-76 progress report).

Winter studies of the forest-dwelling mountain goats of Pinto Creek, Alberta.

1957 Summary of big game range studies in the North Westem Pulp and Power Co., lease area.

1963 Big game range survey of Peace River brakes between ,Peace River and Cadotte River.
Habitat and forage selection of moose in aspen-dominated
Journal / Conference / Etc.

Canadian Field Naturalist, 95, 69-74.

Arctic and Alpine Research, 21, 288-295.

Public Lands Division, Edmonton. Unpublished report.

Alberta Fish and Wildlife Division. Wildlife Resource Inventory Unit, Edmonton, Tech. Rep. No. T173.

Proceedings of North American Moose Conference Workshop, 14, 178-193.

Parks Canada, Calgary. Unpublished report.

Canadian Wildlife Service, Edmonton. Unpublished report.

M.Sc. Thesis. University of Alberta, Edmonton.

M.Sc. Thesis. University of British Columbia, Vancouver, BC.

Prepared for Parks Canada, Calgary. Prepared by Canadian Wildlife Service, Edmonton. Unpublished report.

Canadian Wildlife Service, Edmonton. Unpublished report.

A preliminary report submitted to the Weldwood Forest Management Area integrated resource management steering committee.

Parks Canada, Calgary. Unpublished report.

American Committee for International Wildlife Protection Special Publication. National Museum of Canada, Ottawa, ON.

Canadian Wildlife Service, Edmonton. Unpublished report.

Alces (in review)

Alberta Fish and Wildlife Division, Edmonton. Unpublished report.

Canadian Wildlife Service, Edmonton. Unpublished report.

Preparation for Union Oil Company of Canada Ltd., preparation by LGL Ltd., Sidney, BC.

Canadian Wildlife Service, Edmonton. Unpublished report.

Alberta Fish and Wildlife Division, Edmonton. Unpublished report.

Alberta Fish and Wildlife Division, Edmonton. Unpublished report.

Alberta Fish and Wildlife Division, Edmonton. Unpublished report.

Proceedings of the Biennial Symposium of the Northern Wild Sheep and Goat Council.

Alberta Fish and Wildlife Division, Edmonton. Unpublished report.

Alberta Fish and Wildlife Division, Edmonton. Unpublished report. 


\begin{tabular}{lcl}
\hline \multicolumn{1}{c}{ Author(s) / Editor } & Date & \multicolumn{1}{c}{ Title } \\
\hline Stelfox, J.G. & 1968 & $\begin{array}{l}\text { Condition of elk wintering range along Stony Flats, } \\
\text { Waterton Lakes National Park. }\end{array}$ \\
Stelfox, J.G. & 1970 & $\begin{array}{l}\text { Population dynamics and range ecology of Rocky } \\
\text { Mountain bighorn sheep in the Rocky Mountain natio } \\
\text { parks. }\end{array}$ \\
Stelfox, J.G. & 1972 & $\begin{array}{l}\text { Vegetation and large ungulates of the Suffield Militar } \\
\text { Reserve in southeastern Alberta, August 17-20, 197 }\end{array}$ \\
Stelfox, J.G. & 1975 & $\begin{array}{l}\text { Range wildlife survey committee meeting, Suffield } \\
\text { Military Reserve with special reference to CWS } \\
\text { observations. }\end{array}$
\end{tabular}

Stelfox, J.G. and Tempany, I.

1975 Seasonal bison distributions correlated to habitat types in Wood Buffalo National Park. 2. Late summer (August) period.

Stelfox, J.G., Courtney, J. and McGillis, J.R.

Stelfox, J.G., Kuchar, P. and Bindernagel, J.A.

Surrendi, C.R.

Tanner, H.C.

Telfer, E.S.

Telfer, E.S.

Telfer, E.S.

Telfer, E.S.

Telfer, E.S. and Caims, A.

Telfer, E.S. and Caims, A.

Theberge, J.B. and Milko, B.

Trottier, G.C.

Westworth, D.
1975 Summer use of land systems by large mammals, Bow Valley, Banff National Park, Phase 1: Hillsdale to Lake Louise, 1974.

1978 Range ecology of mountain caribou (Rangifer tarandus caribou) in Jasper National Park, 1971-1974.

1966 Report on range conditions and big game potential of the Kootenay Plains.

1950 An investigation into the competition between elk and big-horned sheep in the Cascade Valley, Banff National Park, Alberta, May 27 - September 7, 1950.

1973 Habitat selection by certain wildlife species in North American forests.

1978 Cervid distribution, browse and snow cover in Alberta.

1978 Habitat requirements of moose - the principal taiga range animal.

1978 Ungulate use in the Marmot Creek experimental watershed.

1979 Bison-wapiti interrelationships in Elk Island National Park, Alberta.

Resource use by moose versus sympatric deer, wapiti and bison.

Preliminary evaluation of winter ungulate use of lower Kananaskis Valley, Alberta.

\section{. Range reconnaissance Willow creek and vicinity, Jasper National Park.}

1972 Caribou-elk winter ecology study, Jasper National Park, March 3-7, 1973.
Journal / Conference / Etc.

Canadian Wildlife Service, Edmonton. Unpublished report.

Canadian Wildlife Service, Edmonton. Unpublished report.

Canadian Wildlife Service, Edmonton. Unpublished report.

Canadian Wildlife Service, Edmonton. Unpublished report.

Canadian Wildlife Service, Edmonton. Unpublished report.

Canadian Wildlife Service, Edmonton. Unpublished report.

Canadian Wildlife Service, Edmonton. Unpublished report.

Alberta Fish and Wildlife Division, Edmonton. Unpublished report.

Canadian Wildlife Service, Edmonton. Unpublished report.

Canadian Wildlife Service, Edmonton. Unpublished report.

Joumal of Wildlife Management, 42, 352-361.

pp. 462-465. In: Proceedings of the 1st International Rangeland Congress.

Canadian Wildlife Service, Edmonton. Unpublished report.

pp. 114-121. In: North American elk: ecology, behavior and management. Boyce, M.S. and Hayden-Wing, L.D. (eds.). University of Wyoming Press, Laramie, WY.

Alces, 22, 114-137.

Environmental Sciences Centre. University of Calgary, Calgary. Unpublished report.

Canadian Wildlife Service, Edmonton. Unpublished report.

Canadian Wildlife Service, Edmonton. Unpublished report. 


Author(s) / Editor

Blood, D.A.

Bouckhout, L.W.

Bouckhout, L.W.

Bromley, P.T.

1977

Bruns, E.H.

1969 A preliminary study of behavioral adaptations of wintering pronghorn antelopes.

Carbyn, L.N.

1975 Factors influencing activity patterns of ungulates at mineral licks.

Case, J.W.

1973 Abnormal behaviour of a pronghorn antelope.

Cowan, I. McT. and Geist, V.

De Bock, E.A.

1970 On the behavior of the mountain goat, (Oreamnos americanus) in Kootenay National Park.

De Vos, A., Brokx, P. and Geist, V.

Egerton, P.J.M.

Egerton, P.J.M.

Egerton, P.J.M.

Festa-Bianchet, M.

Festa-Bianchet, M.

Flook, D.R.

Fuller, W.A.

Gates, C.

Geist, V.

Geist, V.

Geist, V.

Geist, V.

1968 On delayed social and physical maturation in mountain sheep.

Geist, V.

1971 Mountain goat behavior.

Geist, V.

1971 Mountain sheep. A study in behavior and evolution.

Geist, V.

1977 A comparison of social adaptations in relation to ecology of gallinaceous birds and ungulate societies.

Geist, V.

Geist, V.

Geist, V.

Geist, V. and Walther, F. (eds.)
New evidence of high frequency antler wounding in cervids.

1990 Does social behaviour in ungulates reflect population characteristics?

1981

Behavior: adaptive strategies in mule deer.

1971 The behavior of ungulates and its relation to management.
Journal / Conference / Etc.

Canadian Field Naturalist, 77, 77-94.

Alberta Conservation, 1, 4-5.

M.Sc. Thesis. University of Calgary, Calgary.

Ph.D. Thesis. University of Calgary, Calgary.

M.Sc. Thesis. University of Calgary, Calgary.

Canadian Journal of Zoology, 53, 378-384.

Calgary Field Naturalist, 5, 164.

Journal of Mammalogy, 42, 522-526.

M.Sc. Thesis. University of Alberta, Edmonton.

American Midland Naturalist, 77, 390-417.

American Zoologist, 2, 406.

M.Sc. Thesis. University of Alberta, Edmonton.

American Zoologist, 2, 406.

Animal Behavior,

Animal Behavior

Canadian Wildlife Service, Edmonton. Unpublished report.

Arctic, 13, 3-19.

Ph.D. Thesis. University of Alberta, Edmonton.

Zoologische Beitrage, 12, 219-250.

Natural History, 76, 24-31.

University of Calgary, Calgary. Unpublished report.

Canadian Journal of Zoology 46, 899-904.

Wildlife Review, 5, 15-16.

University of Chicago Press, Chicago, IL., 383 pp.

pp. 193-207. In: Animal review of ecology and systematics 8 . Johnston, R.J. (ed.). Palo Alto, CA.

In: Mule and Black-tailed deer of North America. Wallco, D.C. (ed.). Wildlife Management Institute Book. University of Nebraska Press, Lincoln, NE.

Canadian Journal of Zoology 64, 380-384.

Gibier Faune Sauvage, 7, 359-363.

2 vols. IUCN, Switzerland. 


\begin{tabular}{|c|c|c|c|}
\hline Author(s) / Editor & Date & Title & Journal / Conference / Etc. \\
\hline Germain, A. & 1969 & Rutting behavior in the elk. & $\begin{array}{l}\text { Jasper National Park, Parks Canada, Calgary. } \\
\text { Unpublished report. }\end{array}$ \\
\hline Horejsi, B.L. & 1972 & $\begin{array}{l}\text { Behavioural differences in bighom lambs (Ovis canadensis } \\
\text { canadensis Shaw) during years of high and low survival. }\end{array}$ & $\begin{array}{l}\text { pp. 51-73. In: Northern Wild Sheep Council } \\
\text { Symposium. Hinton. }\end{array}$ \\
\hline Kramer, A. & 1973 & $\begin{array}{l}\text { Interspecific behavior and dispersion of two sympatric } \\
\text { deer species. }\end{array}$ & Journal of Wildlife Management, 37, 288-300. \\
\hline Morgantini, L.E. & 1978 & $\begin{array}{l}\text { Ecology and behavior of the Banff Ya Ha Tinda elk herd. } \\
\text { Progress report. }\end{array}$ & $\begin{array}{l}\text { Alberta Fish and Wildlife Division, Edmonton. } \\
\text { Unpublished report. }\end{array}$ \\
\hline Morgantini, L.E. & 1988 & $\begin{array}{l}\text { Behavior adaptive strategies of wapiti in the Canadian } \\
\text { Rocky Mountains. }\end{array}$ & $\begin{array}{l}\text { Ph.D. Thesis. University of Alberta, Edmonton. } \\
193 \text { pp. }\end{array}$ \\
\hline Morgantini, L.E. & 1988 & $\begin{array}{l}\text { Behavioural adaptive strategies of wapiti (Cervus elaphus) } \\
\text { in the Canadian rocky mountains. }\end{array}$ & Ph.D. Thesis. University of Alberta, Edmonton. \\
\hline Petocz, R.G. & 1973 & $\begin{array}{l}\text { The effect of snow cover on the social behaviour of } \\
\text { bighorn rams and mountain goats. }\end{array}$ & Canadian Journal of Zoology, 51, 987-993. \\
\hline Redgate, R.M. & 1978 & $\begin{array}{l}\text { Behavioural and ecological considerations in the } \\
\text { management of elk in Camp 1, Athabasca Valley, Alberta. }\end{array}$ & M.Ed. Thesis. University of Calgary, Calgary. \\
\hline Reid, K.W. & 1964 & $\begin{array}{l}\text { Limited study of bison behavior with respect to spruce } \\
\text { trees. }\end{array}$ & $\begin{array}{l}\text { Canadian Wildlife Service, Edmonton. } \\
\text { Unpublished report. }\end{array}$ \\
\hline Shackleton, D.M. & 1968 & $\begin{array}{l}\text { Comparative aspects of social organisation of American } \\
\text { bison. }\end{array}$ & $\begin{array}{l}\text { M.Sc. Thesis. University of Westem Ontario, } \\
\text { London, ON. }\end{array}$ \\
\hline Shanks, C.C. & 1977 & Cooperative defense by bighom sheep. & Journal of Mammalogy, 58, 243-244. \\
\hline Struthsaker, T.T. & 1967 & $\begin{array}{l}\text { Behavior of elk (Cervus elaphus canadensis) during the } \\
\text { rut. }\end{array}$ & Z. Tierpsychol., 24, 80-114. \\
\hline
\end{tabular}




\begin{tabular}{lcl}
\hline \multicolumn{1}{c}{ Author(s) / Editor } & Date & \multicolumn{1}{c}{ Title } \\
\hline Boreal Ecology Services Ltd. & 1982 & $\begin{array}{l}\text { Feasibility study on the introduction of a disease-free bison } \\
\text { herd in the Slave River lowlands. }\end{array}$ \\
Burgress, T.E. & 1969 & $\begin{array}{l}\text { The suitability of the northern Utikuma Lake area as an } \\
\text { introduction site for elk. }\end{array}$ \\
Calef, G.W. & 1984 & $\begin{array}{l}\text { Population growth in an introduced herd of wood bison } \\
\text { (Bison bison athabascae) }\end{array}$
\end{tabular}

Davidson, T. and Norcross, D.

1978 Report on the wood bison re-introduction to Jasper National Park.

Didrickson, $\mathbf{R}$.

1977 Summary of elk handled during the 1976-1977 winter elk trapping and transplant program at Elk Island National Park.

Eslinger, D.H.

1984 A-7 elk trapping project.

Gates, C.C.

1972 Selection of goat transplant sites.

Gudmundson, L.

1990 Relocation of Livingstone Mountain goats.

Gunderson, G.

1984 Aerial survey to assess the success of the 1982 Pelican Mountain elk transplant, January 17 and 18, 1984.

Hall, B. and Cook, A.

1974 Aerial and ground observations of the Shunda mountain goat transplant.

Haney, R.J.

1978 Free roaming wood bison - Jasper project.

Law, C.E.

LeBlanc, R.K.

1985 A report on trapping and relocation of elk on the Ya Ha Tinda Ranch, Alberta, 1985.

LeBlanc, R.K., and Allen, J.R.

Lloyd, $\mathbf{H}$.

Lynch, G.M.

MacGregor, J.G.

Mair, W.

Novakowski, N.S.

Novakowski, N.S.

Novakowski, N.S.

Paulsen, A.

Quaedvlieg, M., Gunderson, G. and Cook, A.

Quaedvlieg, M., Gunderson, G. and Cook, $\mathrm{A}$.

Reynolds, H.W.

Reynolds, H.W., Lynch, G.M. and 1982 Lajeunesse, B.L.

Rippin, B.
Elk trapping and relocation program, 1984-1985.

\section{Transfer of elk for restocking.}

Transplants of moose and elk from Elk Island National Park by Alberta Fish and Wildlife Division in 1980/81.

The return of the buffalo, Canada's purchase of the Pablo herd.

The impact of an introduced population of elk upon the biota of Banff National Park.

Report on the tagging, testing and slaughtering of bison in the Lake Claire area, Wood Buffalo National Park, October, November, 1957.

Report on the transfer of wood bison, 1963.

Wood bison transfer: completion report.

Elk dispersal - Elk Creek transplant.

Goat transplant - 1972.

Tracking of transplanted goats on Shunda Mountain 1973.

Proposal for the transfer of wood bison to Nahanni region, Northwest Territories, 1980-81.

Range assessment of the Hay-Zama Lakes area, Alberta, as habitat for wood bison and a proposal for their re-introduction.

A comparison of elk ranges as they relate to future transplants in the N.E. region.
Journal / Conference / Etc.

Preparation for Government. Northwest Territories, Department of Renewable Resources.

Alberta Fish and Wildlife Division, Edmonton. Unpublished report.

pp. 183-200. In: Northern ecology and resource management. Olson, R., Geddes, F. and Hasting, R. (eds.). University of Alberta Press, Edmonton.

Parks Canada, Calgary. Unpublished report.

Alberta Fish and Wildlife Division, Edmonton Unpublished report.

Alberta Fish and Wildlife Division, Edmonton. Unpublished report.

Alberta Fish and Wildlife Division, Edmonton. Unpublished report.

Alberta Fish and Wildlife Division, Edmonton. Unpublished report.

Alberta Fish and Wildlife Division, Edmonton. Unpublished report.

Alberta Fish and Wildlife Division, Edmonton. Unpublished report.

Parks Canada, Calgary. Unpublished report.

Canadian Wildlife Service, Edmonton. Unpublished report.

Alberta Fish and Wildlife Division, Edmonton. Unpublished report.

Alberta Fish and Wildlife Division, Edmonton. Unpublished report.

Canadian Field Naturalist, 41, 126-127.

Alberta Fish and Wildlife Division, Edmonton. Unpublished report.

Alberta Historical Review, 2, 4-16.

M.Sc. Thesis. University of British Columbia, Vancouver.

Canadian Wildlife Service, Edmonton. Unpublished report.

Canadian Wildlife Service, Edmonton. Unpublished report.

Canadian Wildlife Service, Edmonton. Unpublished report.

Alberta Fish and Wildlife Division, Edmonton. Unpublished report.

Alberta Fish and Wildlife Division, Edmonton. Unpublished report.

Alberta Fish and Wildlife Division, Edmonton. Unpublished report.

Canadian Wildlife Service, Edmonton. Unpublished report.

Canadian Wildlife Service, Edmonton. Unpublished report.

Alberta Fish and Wildlife Division, Edmonton. Unpublished report. 
Ungulate Translocations

\begin{tabular}{|c|c|c|c|}
\hline Author(s) / Editor & Date & Title & Journal / Conference / Etc. \\
\hline Rippin, B. & 1981 & $\begin{array}{l}\text { History and performance of elk transplant projects in } \\
\text { northeastern Alberta. }\end{array}$ & $\begin{array}{l}\text { Alberta Fish and Wildlife Division, Edmonton. } \\
\text { Unpublished report. }\end{array}$ \\
\hline Schmidt, K.P. & 1984 & $\begin{array}{l}\text { Survival and mortality of translocated elk, Blackstone } \\
\text { River. }\end{array}$ & $\begin{array}{l}\text { Alberta Fish and Wildlife Division, Edmonton. } \\
\text { Unpublished report. }\end{array}$ \\
\hline Smith, K. & 1986 & $\begin{array}{l}\text { A preliminary evaluation of elk transplant to Prospect } \\
\text { Creek (Cadomin) and Kvass flats. (Hell's Gate - Grande } \\
\text { Cache) in Feb., 1985. }\end{array}$ & $\begin{array}{l}\text { Alberta Fish and Wildlife Division, Edmonton. } \\
\text { Unpublished report. }\end{array}$ \\
\hline Smith, K. & 1986 & $\begin{array}{l}\text { Progress report of Mountain Goat capture and transplant } \\
\text { activities in Alberta during } 1986 .\end{array}$ & $\begin{array}{l}\text { Alberta Fish and Wildlife Division, Edmonton. } \\
\text { Unpublished report. }\end{array}$ \\
\hline Smith, K. & 1987 & 1987 Mountain goat transplant program. & $\begin{array}{l}\text { Alberta Fish and Wildlife Division, Edmonton. } \\
\text { Unpublished report. }\end{array}$ \\
\hline Steele, J. & 1975 & $\begin{array}{l}\text { Report on the question of re-introducing bison to Jasper } \\
\text { National Park. }\end{array}$ & Parks Canada, Calgary. Unpublished report. \\
\hline Stevens, W.E. & 1960 & Transfer sites for wood bison. & $\begin{array}{l}\text { Canadian Wildlife Service, Edmonton. } \\
\text { Unpublished report. }\end{array}$ \\
\hline Watson, M. and Lynch, G. & 1986 & $\begin{array}{l}\text { Elk transplants to the Pelican Mountains and Amadou Lake } \\
\text { area in } 1982 .\end{array}$ & $\begin{array}{l}\text { Alberta Fish and Wildlife Division, Edmonton. } \\
\text { Unpublished report. }\end{array}$ \\
\hline
\end{tabular}



